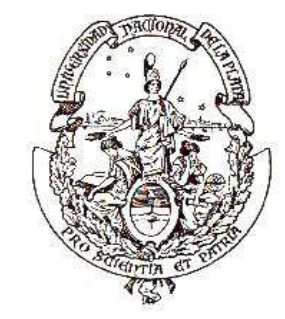

Universidad Nacional de La Plata

Facultad de Humanidades y Ciencias de la Educación

Secretaría de posgrado

\title{
LA VIOLENCIA (ESCOLAR) EN CUESTIÓN
}

UN ESTUDIO EN ESCUELAS SECUNDARIAS PÚBLICAS DE LA CIUDAD DE LA PLATA

Autor: Mg. Nicolás Patierno (UNLP)

Tesis para optar por el grado de Doctor en Ciencias de la Educación

Directores: Dr. Ricardo Crisorio (UNLP)

Dra. Myriam Southwell (UNLP) 


\section{Índice}

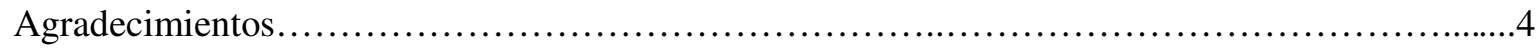

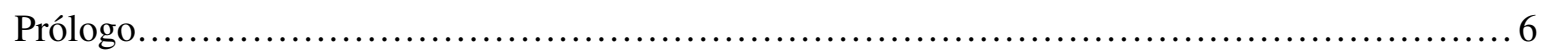

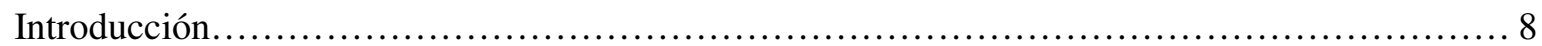

Capítulo 1. Las presuntas manifestaciones del fenómeno ..................................29

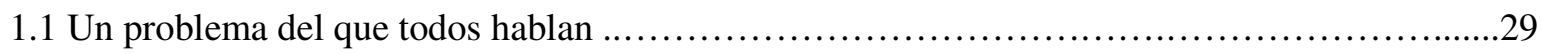

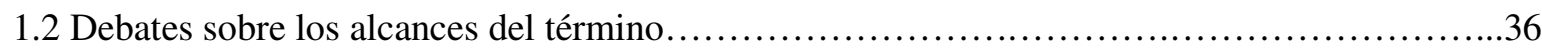

$1.3 \mathrm{El}$ desnivel en los parámetros de percepción..........................................

1.4 La multiplicidad de manifestaciones.............................................46

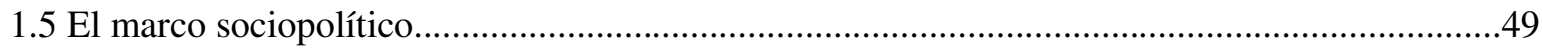

1.6 Debates sobre el recrudecimiento de la problemática................................................................54

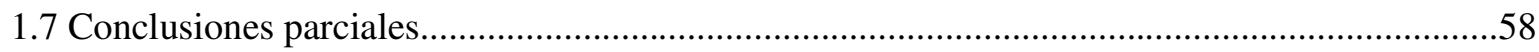

Capítulo 2. La reconfiguración de la autoridad...........................................................................61

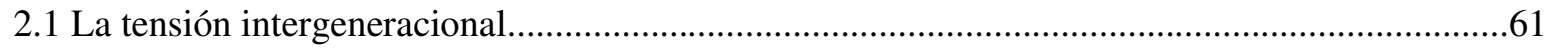

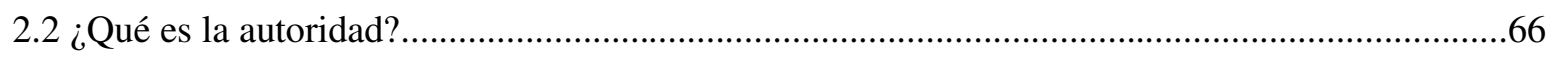

2.3 Debates en torno a la asimetría de la autoridad........................................................................

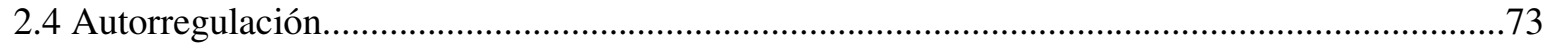

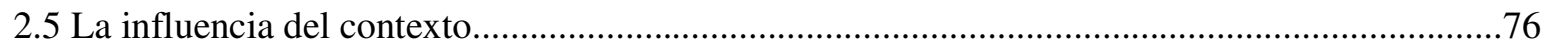

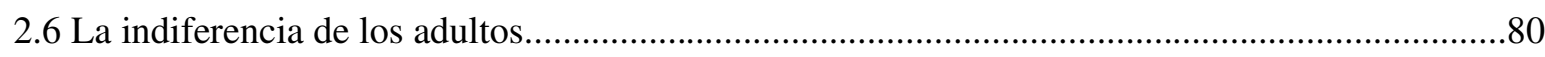

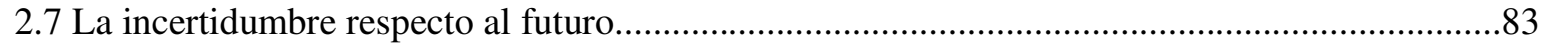

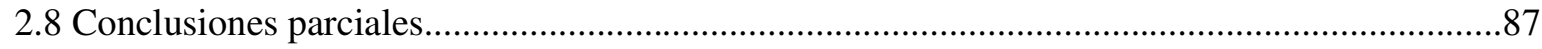

Capítulo 3. El debilitamiento del lenguaje...............................................................................90

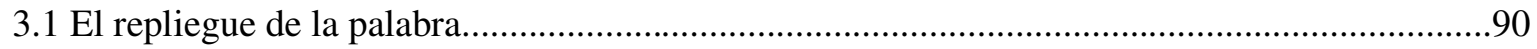

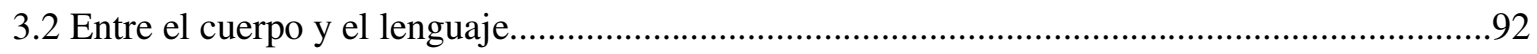

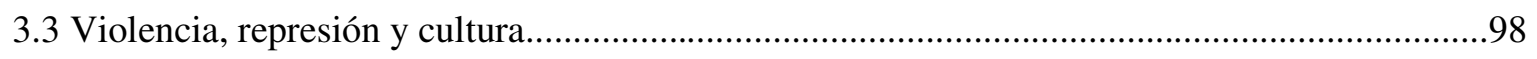

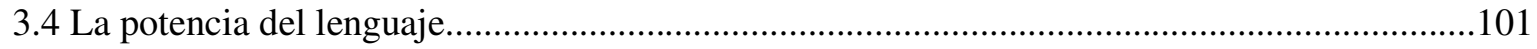

3.5 La constitución del orden simbólico..............................................107 


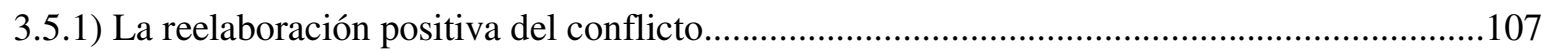

3.5.2) La rearticulación cuerpo-lenguaje.....................................................................................110

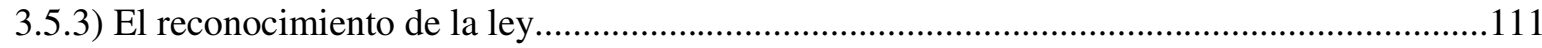

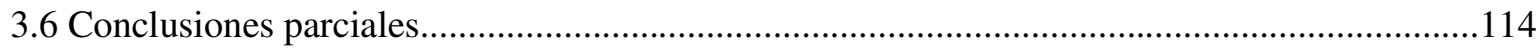

Capítulo 4. La relevancia de la escuela en la metabolización de la violencia.................................116

4.1 La representación "optimista" de la escuela...........................................................................116

4.2 La representación "fatalista" de la escuela..........................................................................123

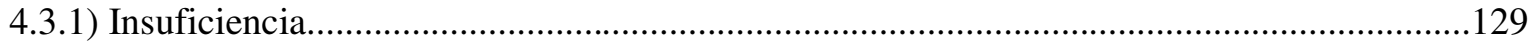

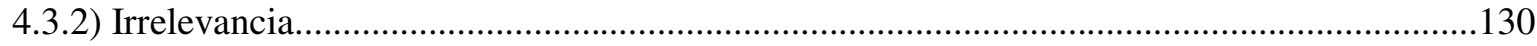

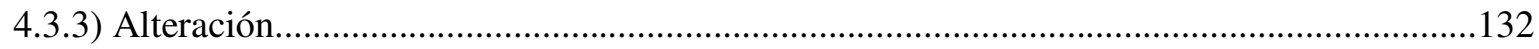

4.4 Los efectos nocivos de la burocracia y la "vorágine escolar"..................................................135

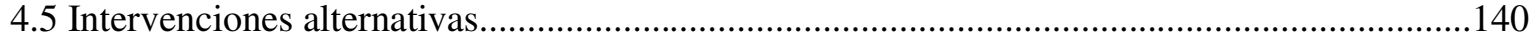

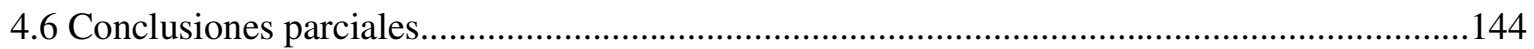

Capítulo 5. El pasaje automático al acto.................................................................................. 146

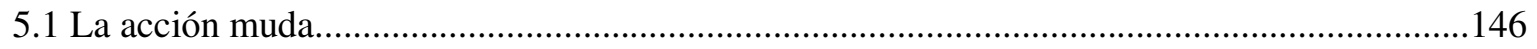

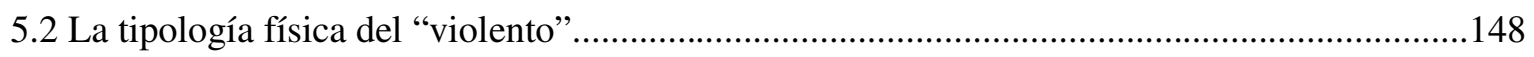

5.3 "Nos peleamos porque sí"............................................................................................... 151

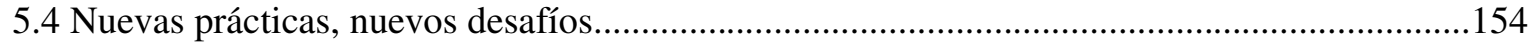

5.5 El juego: la relevancia de la negociación y la pautación de reglas..........................................156

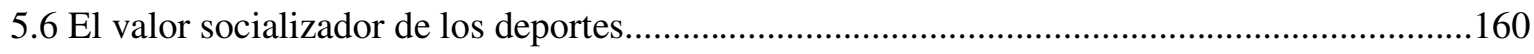

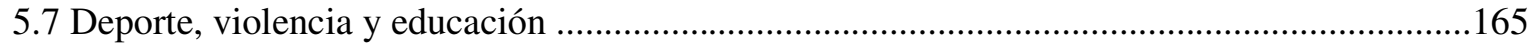

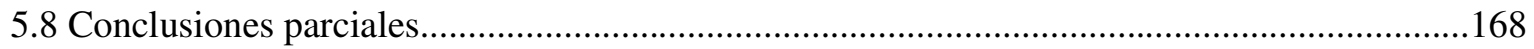

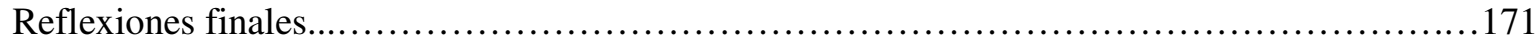

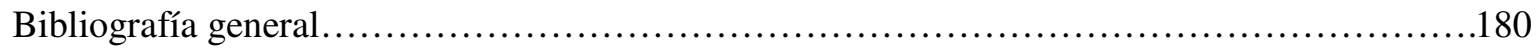

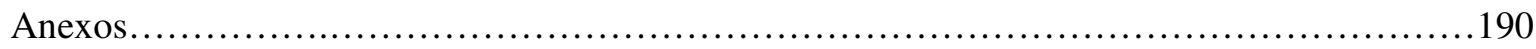




\section{Agradecimientos}

En primer lugar, quisiera agradecer a la Universidad Nacional de La Plata y al CONICET, instituciones que a partir de sus becas me permitieron acercarme con "dedicación exclusiva" al mundo de la investigación. Sin su financiamiento, este trabajo hubiera quedado postergado por algunos años más.

A mi director, Ricardo Crisorio, por su permanente colaboración y fundamentalmente por ayudarme a formar parte del atrapante mundo de la investigación en el contexto de las Humanidades; también por escucharme cuando nadie más lo hacía y por brindarme oportunidades cuando las puertas solo se cerraban. En esta línea también deseo incluir a Myriam Southwell, mi codirectora, por la excelente predisposición que tuvo desde el primer momento y por la minuciosidad y precisión de sus consejos; sus aportes fueron de suma importancia para la confección del presente trabajo.

No puedo dejar de incluir a los alumnos, docentes, directivos y miembros de Equipos de Orientación Escolar que participaron desinteresadamente de las entrevistas: sin su predisposición a compartir opiniones y sugerencias, la presente tesis no hubiese podido llevarse a cabo.

Quiero dar gracias también al Instituto de Investigaciones en Humanidades y Ciencias Sociales, al Doctorado en Ciencias de la Educación, al Departamento de Educación Física y, particularmente, a los miembros del Centro Interdisciplinario Cuerpo, Educación y Sociedad por el constante diálogo y por permitirme ser parte de sus vidas, compartiendo mates, proyectos y haciendo más entretenida la mal llamada "solitaria" tarea de investigar.

Sin los esfuerzos de Liliana Rocha Bidegain en lo referente a la construcción del marco metodológico, esta tesis carecería de su columna vertebral. Sus aportes fueron sumamente pertinentes y necesarios.

Deseo agradecer a Pablo Kopelovich, amigo y colega, por leer desinteresadamente todas "las versiones preliminares" y por compartir los primeros pasos en el complejo mundo de las becas de investigación. 
Quiero destacar el profesionalismo de Bruno Crisorio en el proceso de revisión final.

Deseo agregar también a mis padres Elvira y Carmelo, a mi hermana Eva y a mi abuela Edith, quienes debieron padecer mis ausencias y locuras "por la tesis". Cada palabra de esta tesis es para ustedes, su ayuda me acompaña en cada paso que doy.

Quiero sumar a Giuliana por escucharme, por bancarme las madrugadas en las que hablo solo, por estar siempre a pesar de las obligaciones y por su amor incondicional. Con el mismo amor, esta tesis también te pertenece. 


\section{Prólogo}

La presente tesis es el producto de una investigación realizada entre los años 2011 y 2018 , en la Universidad Nacional de La Plata, financiada en primer lugar mediante una beca otorgada por esta institución, y luego mediante una beca del Consejo Nacional de Investigaciones Científicas y Técnicas. La decisión de encarar una investigación enfocada en la cuestión de la violencia en las escuelas se produce a raíz de tres motivos: a) revisar y desnaturalizar varios discursos vinculados con el problema comúnmente denominado "violencia escolar", b) contribuir (simbólicamente) con el sistema educativo público de la Provincia de Buenos Aires (del que formé parte como alumno y actualmente lo hago como docente), y c) la posibilidad de plasmar los motivos recién mencionados en el marco de los estudios correspondientes al Doctorado en Ciencias de la Educación.

Para el año 2011, la temática de la violencia en las escuelas ya se encontraba instalada en el ámbito educativo público y académico. Los que por entonces eran considerados estudios contemporáneos sobre educación advertían sobre la aparente presencia de diversas problemáticas asociadas en menor o mayor medida con la violencia. No obstante, un evento vivido en primera persona sirvió como detonante para adentrarme de lleno en esta temática. Ese año, mientras me desempeñaba como profesor en la asignatura Construcción de la Ciudadanía, recibí las amenazas de un alumno de unos doce o trece años; en ese entonces no lo sabía, pero casi diez años después puedo identificar ese momento como la génesis del presente trabajo. Si bien no se trató específicamente de un hecho violento en términos físicos, no hay dudas de que lo experimenté como una situación traumática. A pesar de haber pasado posteriormente por situaciones similares, las amenazas recibidas entonces constituyeron un antes y un después en mi carrera como docente y como investigador. Sencillamente no podía continuar con la rutina y la "vorágine escolar", haciendo de cuenta que no había sucedido nada. La ira y el enojo que ese joven manifestaba evidenciaban también su temor, su vulnerabilidad, la ausencia de la familia, del estado, del sistema educativo; era como si todo lo que la modernidad había erigido durante siglos se hubiese desmoronado en una sola hora de clases.

Algunos años después, con la realización del trabajo de campo que acompaña la presente tesis, pude darme cuenta de que estaba lejos de haber experimentado un 
acontecimiento aislado; por el contrario, la totalidad de los entrevistados (tanto docentes como alumnos) tenían algo para decir sobre la violencia. Posicionándose mayormente desde el lugar de víctimas, todos reconocieron -con diferentes matices- la presencia de esta problemática en sus respectivas escuelas. Supe entonces que había mucho por indagar; el oído y la ayuda de mi director, Ricardo Crisorio, de mi co-directora, Myriam Southwell, y de mis compañeros de investigación del Centro Interdisciplinario Cuerpo, Educación y Sociedad, constituyeron el respaldo que necesitaba para adentrarme de lleno en la temática desde un punto de vista académico. 


\section{Introducción}

Desde hace dos o tres décadas, muchos educadores, basados en una gran cantidad de supuestos, consideran que la violencia se trata de un fenómeno factible -y de magnitud creciente- en el escenario escolar contemporáneo. Esta afirmación suele estar acompañada por el agregado de que todos $-\mathrm{o}$ al menos todos los que trabajamos regularmente en la educación pública- entendemos el significado de la violencia y confirmamos que es posible articular escuela y violencia en una misma oración. Esta peligrosa naturalización de supuestos ha llegado incluso a trascender el espacio específicamente escolar: la problemática comúnmente conocida como "violencia escolar", hoy no se restringe únicamente a la docencia y la investigación educativa, sino que -particularmente en los últimos tiempos-, se ha instalado como un debate público. El problema se visibiliza en redes sociales, en programas radiales, en la televisión, en diarios, en revistas; pero, a pesar de que muy pocos dudan en afirmar que la violencia "forma parte" de la cotidianeidad escolar -y de acuerdo a varios medios de comunicación, pareciera recrudecerse aún más en el nivel secundario-, en realidad nadie sabe bien cómo detallar este fenómeno, ni qué hacer al respecto.

Es preciso aclarar que esta construcción de la "violencia escolar" no refiere a los excesos en la aplicación de sanciones disciplinarias; la representación contemporánea de la violencia que irrumpe en la escuela, por el contrario, adopta un carácter multidireccional, involucrando a actores y situaciones que históricamente no formaban parte del paisaje escolar. A pesar de que las "nuevas violencias" han llegado a naturalizarse tanto en el interior como en el exterior de las instituciones educativas, hay algo en dicha enunciación que resulta incómodo, contradictorio, perturbador. En el concepto "violencia escolar" colisionan dos tendencias históricamente antagónicas: por un lado tenemos la escuela, la institución donde se reúne y se socializa a las nuevas generaciones; el primer lugar fuera de la familia dónde los jóvenes comienzan a reconocer la presencia de otros miembros de la sociedad. Por otro lado, la violencia, concepto que, por su carácter relacional, situacional y cambiante resulta muy difícil de definir, pero que ineludiblemente conlleva una fuerte carga social negativa. Si bien su significado puede variar, no suele ocurrir lo mismo con su percepción. En un diálogo referido a la violencia, el receptor puede entender algo distinto a 
lo que intenta transmitir el emisor - de hecho es muy poco probable que dos personas interpreten la violencia de igual modo-; no obstante, tanto el emisor como el receptor probablemente acuerden en que la violencia refiere a algo malo, peligroso e indeseable. Por lo tanto, la introducción de la violencia en el ámbito escolar representa, en términos históricos, una novedad y al mismo tiempo una contradicción, o, en términos de Duschatzky y Corea, un "fuera de lugar, una irrupción que resulta inconsistente con la representación de una escuela" (2013: 28).

La tensión que se genera al asumir que la violencia ha irrumpido en el escenario escolar, sin embargo, también es sinónimo de esperanza. La incomodidad que resulta de asumir que algo perturbador está aconteciendo en un lugar que originalmente fue pensado para el cuidado de los "nuevos", como los llama Hannah Arendt (1996), constituye, al mismo tiempo, el motor que debe movilizarnos para indagar este fenómeno en profundidad. Indagar esta problemática implica, aunque hoy suene algo presuntuoso, sostener la confianza en la escuela como una institución civilizadora o, dicho de otro modo, como un lugar en el que es posible apropiarse de diversos mecanismos simbólicos tendientes a sustituir el uso de la fuerza física.

Siguiendo con este paneo inicial, advertimos que varias investigaciones dedicadas al fenómeno en cuestión no se preocupan en aclarar qué entienden por violencia, y en muchos casos ni siquiera plantean desde qué perspectiva se posicionan. Lejos de tratarse de un asunto menor, creemos que esta falta de "sustento teórico" promueve la producción y reproducción de algunas arbitrariedades, popularizando, en ocasiones, nociones ambiguas y contradictorias. De acuerdo con Kaplan, "cuando un término tiene muchas acepciones en el lenguaje común, o se lo refiere con vaguedad, o se lo identifica ambiguamente, incluso si se lo caracteriza en formas contradictorias, hay serios problemas" (2015: 29). Dicho de otro modo, cuando una palabra es empleada para definir todo, termina por no definir nada.

Como dijimos, la caracterización del "violento" arrastra una fuerte carga social negativa. Siguiendo a Kornblit, "en nuestras sociedades esa categoría se encuentra asociada a comportamientos o palabras inaceptables, insoportables, contrarios a la civilización, la humanidad, la modernidad" (2008: 18). Históricamente, los "violentos" no fueron considerados aptos para vivir en sociedad; en términos foucaultianos, podría decirse que su condición de "indocilidad" era motivo suficiente para ser clasificados, excluidos y 
reencauzados por los medios que fueran necesarios (aun cuando tales medios implicaran todavía más violencia) (Foucault, 2002). Asimismo, el señalamiento del "violento" también sirvió -y sirve- para enmascarar un proceso de discriminación a través del cual se suelen atribuir -arbitraria y tendenciosamente- ciertos comportamientos des-civilizatorios a la condición de pobre, de inmigrante, de excluido, de diferente, de extranjero. Por el contrario, Bleichmar explica que "hay que terminar con el mito de que la violencia es producto de la pobreza. La violencia es producto de dos cosas: por un lado, el resentimiento por las promesas incumplidas y, por otro, la falta de perspectiva de futuro" (2008: 35).

En contraposición a cualquier tendencia esencialista, la presente investigación intenta escapar de las perspectivas que asocian mecánicamente la violencia con cualquier determinismo, más precisamente, con los procedentes de la criminología, las teorías lombrosianas de delincuencia y el derecho punitivo. Anticipadamente, podemos decir que una sociedad que tacha de "violentos" a sus jóvenes sin enjuiciarse primero a sí misma, es una sociedad con pocas perspectivas de futuro.

Desde la portación de armas hasta las dificultades en la lecto-escritura, pareciera que, en el contexto de una escuela secundaria, cualquier acto puede de ser catalogado como "violento". El problema que ineludiblemente arrastra la violencia, como se dijo anteriormente, es que se trata de una palabra cargada de prejuicios y estigmatizaciones. Lejos de tratarse de un asunto de poca relevancia, creemos que esta multiplicidad de significados favorece la producción y reproducción de prácticas excluyentes; es por esto que consideramos necesario llevar adelante una investigación cuyos elementos constituyentes serán detallados a continuación.

La presente tesis tiene como objetivo sistematizar y analizar las diversas manifestaciones que, de acuerdo al relato de alumnos y educadores, suelen considerarse "violentas". Esta tarea fue llevada a cabo en tres escuelas públicas secundarias de la ciudad de La Plata, a través de una investigación de tipo cualitativa sustentada en la revisión de fuentes documentales y en la realización de entrevistas a informantes considerados claves. La hipótesis que guía esta investigación presupone que los actos que tanto educadores como alumnos suelen identificar como "violentos" se producen, fundamentalmente, a causa de dos fenómenos: una reconfiguración de la autoridad y un debilitamiento del lenguaje; procesos que, si bien exceden lo estrictamente escolar, dificultan considerablemente la 
constitución de lazos sociales en su interior. El efecto resultante de estos movimientos es la autorregulación que se espera de y en definitiva se impone a los propios jóvenes, ${ }^{1}$ lo que deriva en la conformación de grupos -en cierto modo clánicos o tiránicos- en los que la violencia, entendida como una manifestación "más física" que revela la escasez de recursos simbólicos, se impone como un medio de relación naturalizado, habitual, no identificable como falta o trasgresión.

Con respecto al marco teórico, es preciso señalar que, lejos de sustentarse en las ideas de un autor o en una línea específica de pensadores, la tesis recorre diversas tradiciones y autores provenientes de áreas diferentes. El eje que ordena la selección de determinados pensadores es el enfoque histórico-político, es decir, se privilegiará el diálogo con aquellos que entienden que la violencia es un problema de carácter relacional, que sus características cambian a lo largo de la historia y que sus manifestaciones se hallan en estrecha relación con las condiciones políticas reinantes. Partiendo de esta premisa, la presente investigación se nutre de trabajos tales como los desarrollados por Hannah Arendt (2006), quien conceptualiza la violencia como un fenómeno con rasgos propios y que su estudio, aunque necesario en relación a los vertiginosos cambios acontecidos en el siglo $\mathrm{XX}$, posee un desarrollo exiguo en las Ciencias Humanas. Asimismo, sus reflexiones acerca de los cambios en la autoridad educativa y la autonomía infantil nos permiten adentrarnos en el análisis de "las crisis" de los sistemas educativos modernos. En La crisis de la educación, ensayo publicado hace alrededor de sesenta años, ${ }^{2}$ Arendt advertía que sin tradición ni autoridad es imposible llevar a cabo cualquier tarea educativa, y que el destino de los jóvenes, desatendido por los adultos, conllevaría un protagonismo autodestructivo que acabaría por disolver las relaciones intergeneracionales. A pesar del tiempo

\footnotetext{
${ }^{1}$ El término autorregulación no es tomado como sinónimo de apaciguamiento; por el contrario, consideramos a la autorregulación como una manera de manifestarse -individual o grupalmente- de manera independiente a los hábitos y a las leyes instituidas en una sociedad. Adentrándonos poco a poco en esta problemática, consideramos pertinente atender algunas reflexiones de Arendt (1996) en las que articula la cuestión de la autorregulación con el estado general de la educación media estadounidense hacia mediados del siglo XX. Para la autora mencionada, la desatención de los adultos y la consecuente "autorregulación infantil", serían los principales motivos por los que muchos jóvenes en edad escolar se han visto obligados a resguardarse -y a someterse- dentro del propio grupo de pares. Bajo una estructura en cierto modo "tiránica", donde las principales decisiones son tomadas por la fuerza de unos pocos, los jóvenes se encuentran "mucho peor que antes"(Arendt, 1996: 193), debido a que la autoridad depositada en el grupo siempre será -a causa de la superioridad numérica- más inclemente si se la compara con la más rigurosa autoridad individual.

${ }^{2}$ La crisis de la educación es un ensayo publicado originalmente en la revista Partisan Review y posteriormente incluido en el libro Entre el pasado y el futuro: ocho ejercicios sobre la reflexión política [1961].
} 
transcurrido, creemos que este análisis, aunque suene algo dramático, cuenta con una vigencia considerable, sobre todo si tenemos en cuenta que muchas investigaciones actuales referidas a la violencia en las escuelas mencionan los cambios en la autoridad como una de las principales causas del fenómeno.

Los estudios de Norbert Elias, por su parte, también constituyen una fuente teórica pertinente para respaldar el análisis de varios temas desplegados a lo largo esta investigación. Si bien a primera vista pareciera que la violencia no es una cuestión central en su obra, este concepto adquiere particular relevancia cuando lo articula -y lo tensionacon lo que él denomina el proceso de la civilización (Elias, 1981). Resumidamente, para este sociólogo, la violencia es un concepto cambiante a lo largo de la historia, constituyendo un parámetro de medición al mismo tiempo que un problema de índole social. Volviendo la atención hacia la cuestión de la violencia en las escuelas, creemos que sus aportes pueden servirnos para, en cierta forma, "desencializar la violencia", es decir, interpretar ciertas reacciones no como conductas innatas o instintivas, sino como respuestas a la alteración de los lazos sociales. Kaplan ha señalado que los planteos de Elias abren la posibilidad de pensar la coexistencia de "fenómenos contemporáneos de des-civilización y des-subjetivación [...] con los procesos históricos de civilización y subjetivación” (2015: 25); adherir a esta lectura implica asumir que ningún joven es violento por sí mismo, sino que sus acciones se enmarcan en una compleja red de interrelaciones. Es allí, en el entramado social -y no en la singularidad-, donde deben rastrearse y combatirse las causas de los estallidos violentos. Por último, los aportes de Elias, particularmente los desplegados en Deporte y ocio en el proceso de la civilización (1992, en coautoría con Eric Dunning), también nos sirven de sustento para analizar el juego y el deporte como prácticas tendientes a la pacificación y al reconocimiento de los usos legítimos del cuerpo.

Si bien Jacques Lacan centra su atención en la noción de agresividad, sus estudios asociados a la potencia del lenguaje y la experimentación del cuerpo constituyen un sustento fundamental para el desarrollo de la hipótesis que recorre la presente investigación. La idea de que el lenguaje funda un orden simbólico capaz de, justamente, ordenar los lazos sociales, nos habilita a reconsiderar la importancia de "lo simbólico" en la mitigación de la violencia. Sintéticamente, para Lacan (2010) la violencia implica aislación y ruptura, se trata de un comportamiento excepcional que se caracteriza por la trasgresión 
de un límite socialmente establecido. Las contribuciones posibles que sistematizamos a partir de las reflexiones lacanianas se centran en la posibilidad de introducir el lenguaje como un elemento pacificador; esta construcción opera como un punto de partida fundamental a la hora de buscar respuestas a la pregunta: ¿qué hacer con el asunto de la violencia en las escuelas?

Con respecto a los antecedentes específicos sobre violencia y escuelas, consideramos preciso hacer una aclaración: pensar la violencia en relación a la escuela se trata de un ejercicio relativamente nuevo. Como dice Kaplan, "no existe una tradición de estudios socioeducativos en nuestro país que dé lugar a un campo propio de indagación; en todo caso, es un campo en construcción" (2015: 21). Esto sugiere que el estudio de la violencia en las escuelas aún se encuentra influenciado por varios prejuicios y ambigüedades. Estas dificultades epistemológicas se suman a las ya presentes en cualquier estudio referido a la violencia. A primera vista, cuando hablemos de violencia parece que hablamos de algo habitual, recurrente, vulgar; no obstante, cuando nos adentramos de lleno en esta temática, poco a poco advertimos que esta recurrencia no suele estar acompañada de acuerdos. La violencia evoca sucesos heterogéneos y, al mismo tiempo, perturbadores. Esto explica que las investigaciones referidas al fenómeno deban romper con ciertas estructuras tradicionales en materia de investigación educativa. ${ }^{3}$ Recordemos que hablar de violencia y escuela constituye, en términos de representación social, una contradicción. Otorgarle credibilidad a esta construcción implica reconocer que algo anda mal en un lugar donde todo debería andar bien. ${ }^{4}$

\footnotetext{
${ }^{3}$ Una de las mayores dificultades que se generan alrededor del estudio de la violencia, en términos generales, es el hecho de que los investigadores abocados a esta temática se encuentran atravesados por los mismos eventos que relatan las "víctimas". Tal como advierte Castorina: "el científico social parte de lo que vivencian y leen como actos violentos los actores, incluso por él mismo en cuánto participe cotidiano de la vida social” (2008: 85). En el caso específico del estudio de la violencia en las escuelas, al asumir que se trata de un problema social, no se puede desmentir el hecho de que cualquier estudio orientado a esta temática va a estar influenciado por presupuestos de orden filosófico, ético, teórico, político que adquieren relevancia en todo el proceso de investigación (Vasilachis de Gialdino, 2006).

${ }^{4}$ Esta contradicción o discordancia se hace evidente en el relato de algunas autoridades entrevistadas, cuyos testimonios de carácter "institucional", tendientes a relativizar los acontecimientos comúnmente asociados a la violencia, evidenciaban cierta resistencia a asumir la existencia de la problemática en la escuela en la que desempeñan sus funciones. En algunos casos esta resistencia se hizo más explícita al anteponer una serie de preguntas referidas al destino de la presente investigación, y solicitar cuidados a la hora de su publicación. D’Angelo y Fernández también se toparon con esta dificultad al adentrarse en las escuelas con intenciones de estudiar la violencia: "la situación en el caso de los directores no siempre es equivalente, y en casos puntuales se percibieron algunos indicios de potencial reticencia. Una vez más, esto tiene una explicación relativamente
} 
El análisis de los estudios desarrollados en Argentina sobre la temática planteada no aporta datos significativos anteriores a los últimos quince años; esto, lógicamente, sugiere que el fenómeno cobró importancia recientemente, en especial a partir de los casos de los alumnos Javier Romero (caso Pantriste) y Rafael Solich (masacre de Carmen de Patagones), ${ }^{5}$ ambos víctimas de burlas y acosos frecuentes. Sobre la disponibilidad de investigaciones y datos estadísticos, Kaplan advierte que, "a diferencia de otros países, la Argentina no cuenta con informes sistemáticos actualizados sobre las intervenciones en el tema de violencia y educación" (2015: 23). A partir del año 2004, el Ministerio de Educación de la Nación y la Universidad Nacional de San Martín iniciaron una serie de trabajos sobre violencia en las escuelas, cuyos resultados han sido publicados en el marco del Observatorio Argentino de Violencia en las Escuelas. Estos trabajos, junto a otras investigaciones tales como las desarrolladas por Silvia Duschatzky y Cristina Corea [2001], Fernando Onetto [2004], Carina Kaplan [2006], Fernando Osorio [2006], Ana Lía Kornblit [2008], Silvia Bleichmar [2008], José Antonio Castorina [2008], Luis D’Angelo y Daniel Fernández [2011], Miguel Ángel Furlán [2013], ${ }^{6}$ entre otros, fueron conformando un material teórico y estadístico a partir del cual se pueden obtener datos relevantes sobre la temática planteada.

Centrando la atención en la hipótesis que guía la presente investigación, algunos trabajos cobran mayor relevancia debido a la cercanía teórico-metodológica. Tal es el caso de Chicos en banda, libro publicado originalmente en el año 2001 por Silvia Duschatzky y Cristina Corea. Allí las autoras articulan el análisis de los comportamientos de un grupo de

sencilla en cuanto el reporte de situaciones conflictivas puede ser leído como síntoma de impericia o ineficacia por parte del cuerpo directivo o docente de la escuela" (2011:30).

${ }^{5}$ El caso "Pantriste" hace referencia al hecho ocurrido en el año 2000, en el que un alumno de diecinueve años perteneciente a un colegio de Rafael Calzada asesinó de un balazo a un compañero e hirió a otro en el momento de la salida. El apodo fue acuñado por sus compañeros de primer año del Polimodal, quienes lo llamaban "Pantriste" haciendo referencia a un personaje tímido de una película animada de García Ferré (film estrenado un mes antes). Cuatro años después, en la ciudad de Carmen de Patagones, un joven de quince años apodado "Junior" disparó dentro del Instituto Islas Malvinas contra sus compañeros con una pistola (que había robado a su padre), ocasionando la muerte de tres de ellos e hiriendo a otros cinco. Como señala Bleichmar, "vemos en este caso un paradigma terrible de violencia homicida, banal, porque Junior no era un chico con problemas en la escuela: aprendía bien y no hacía ruido, no era un violento ruidoso de esos que pegan o maltratan a sus compañeros [...]. Hubo varios casos como esos, en los que la violencia emerge de golpe porque ha sido silenciada mucho tiempo; en ellos es difícil descubrir las pautas" (2008: 35). Estos hechos despertaron la alarma sobre la cuestión del acoso -o bullying- en contextos escolares y son considerados hasta el día de hoy como los casos de violencia más graves ocurridos en escuelas argentinas.

${ }^{6}$ Los años en que las investigaciones mencionadas fueron publicadas por primera vez fueron referenciados entre corchetes; no obstante, para la presente investigación se utilizaron, en la mayoría de los casos, reimpresiones posteriores (cuyo año de publicación está indicado entre paréntesis). 
jóvenes situados en las afueras de la ciudad de Córdoba con el estudio de las condiciones socio-políticas de la época (caracterizada por un pronunciado declive en la función material y simbólica de las instituciones). Centrando la atención en los efectos de la marginalidad, Duschatzky y Corea advierten la presencia, cada vez mayor, de nuevas formas de vinculación debidas a compartir las mismas necesidades y caracterizadas por la instauración de códigos propios. En este contexto, la escuela parece tomar distancia de las funciones asignadas en sus orígenes modernos: "la escuela parece desdibujada [...], no son registradas sus marcas" (Duschatzky y Corea, 2013: 10). Esto condiciona determinantemente la constitución de subjetividades, cambiando radicalmente el eje de referencia, esto es, anteponiendo la pertenencia al grupo sobre la institución. "La fragilidad de las figuras adultas, el aguante, la creación de valores propios de las situaciones, la percepción constante del riesgo, nos iban mostrando rostros juveniles muy alejados a aquellos niños soñados y fabricados por la escuela" (Duschatzky y Corea, ibíd.: 11).

La conexión con la hipótesis que se plantea en este trabajo reside en la posibilidad de pensar que las nuevas generaciones, sistemáticamente desatendidas por los mayores, son arrojadas a su propia suerte, creando las condiciones propicias para que los jóvenes se regulen a sí mismos. Las autoras deciden nombrar este fenómeno como la conformación de bandas. Si bien se trata de una caracterización a la que no adherimos, los detalles de esta construcción son pertinentes a las ideas aquí desarrolladas.

Como antecedente particularmente relevante, también es preciso incluir algunos de los trabajos desarrollados por Kaplan. Con un claro matiz sociológico, la autora toma distancia de los señalamientos y de las estigmatizaciones que se construyen alrededor de la violencia en contextos escolares. Se destaca la dirección de dos obras publicadas como resultados de una serie de investigaciones abocadas a la problemática: Violencias en plural. Sociología de las violencias en la escuela [2006] y Violencia escolar bajo sospecha [2009]. Sus libros, junto a otros capítulos y artículos académicos, son hoy considerados fuentes ineludibles de información en lo que respecta al estudio de la problemática en cuestión. Muy sintéticamente, la autora advierte que la violencia evoca sucesos muy disímiles y atravesados por diversas construcciones sociales; estas múltiples causas imposibilitan la instauración de una explicación única y acabada. Es por este motivo que Kaplan (2015) alude a las violencias en sentido plural; en otras palabras, afirma que la inmensa 
variabilidad de significados y manifestaciones comúnmente agrupados bajo el rótulo de violencia varían de acuerdo a los contextos en los que se desarrollan. En sus términos: "preferimos el uso del plural, las violencias, precisamente por sus múltiples manifestaciones y significados" (2015: 16).

Nuestro trabajo adhiere al manifiesto rechazo de Kaplan a las visiones judicializantes y a la criminalización que envuelve el imaginario social que habitualmente se construye sobre los estudiantes como sujetos peligrosos. A través de un minucioso ejercicio de revisión, la educadora desarticula la idea, fuertemente arraigada en nuestra cultura, por la que se presupone que los jóvenes son naturalmente violentos. Esta construcción se fundamenta en una "visión dualista que instaura al individuo o grupo violento por naturaleza, esto es, por fuera de toda práctica histórica, coincidente con una forma de ver que predominó en el siglo XIX” (2009: 20). Para Kaplan no existe algo así como un "gen de la violencia", esta no es hereditaria ni es singular. En contrapartida, y en explícito acuerdo con las ideas de Elias, la autora sostiene que "son las sociedades las que tornan brutales a las personas y no su naturaleza individual. En todo caso, es la miseria de la sociedad la que vuelve miserables a las personas que la habitan” (2015: 15-16).

La naturalización de la violencia se basa en una supuesta "naturaleza humana violenta" que suele entremezclarse peligrosamente con la idea de agresividad o agresión, suponiendo que la fuerza es una conducta primordial e ineludible, impresa en el ser humano desde su nacimiento. La violencia entendida como parte esencial del ser humano, como un comportamiento inherente a su existencia, suele vincularse con una interpretación marcadamente biológica de la vida. Explicar la violencia a partir de cierta animalidad latente es absolutamente arbitrario y determinista; en contraposición, podríamos considerar que los animales no son violentos y que sencillamente se comportan de acuerdo a sus instintos. De esta manera, serían los humanos los que atribuirían caracteres violentos a los animales para justificar su propio comportamiento. La sentencia de Arendt es clara: "la violencia ni es bestial ni es irracional" (2006: 84). Esta aclaración se hace fundamental en vistas de un alejamiento de las explicaciones provenientes de la biología, la fisiología y la zoología, disciplinas que pretenden atribuir al humano cierta violencia o agresividad fundada en el estudio de otras especies. ${ }^{7}$

\footnotetext{
${ }^{7}$ Véase al respecto Patierno (2018a).
} 
Retomando los aportes de Kaplan (2015), podríamos decir que en la "resolución física" de conflictos en contextos escolares confluyen, al menos, dos causas: por un lado las generales, derivadas del contexto histórico-político, y por otro las "situacionales", derivadas de las relaciones interpersonales que se suceden en el interior de las instituciones educativas. Este posicionamiento permite atender tanto los condicionantes "macro" (las decisiones políticas, la gestión de los ministerios, la distribución de recursos, etcétera), como los problemas comúnmente denominados "micro" (el ausentismo, la repitencia, la sobreedad, la falta de claridad en las reglas, las operaciones ambiguas ante la inconducta, la irrelevancia de las normas, la existencia de relaciones conflictivas entre docentes y directivos, direcciones inactivas o ausentes, bajos recursos y altas tasas de alumnos por docente, etcétera). Resumiendo, ninguno de los elementos que comúnmente suelen agruparse bajo el paraguas de la violencia en las escuelas puede ser analizado de manera aislada. En términos de Kaplan, "se trata de pensar a los actores escolares y a sus prácticas, a sus experiencias y trayectorias en tanto que sujetos históricos en coyunturas particulares" (2015: 19).

Cabe destacar que dos de los trabajos de Kaplan referidos a la violencia en las escuelas adquieren particular relevancia como antecedentes locales. Una de las cuatro ciudades referidas en el trabajo de campo incluido en Violencia escolar bajo sospecha es, precisamente, La Plata. De igual modo, su capítulo de libro titulado "La persistencia de la desigualdad" (incluido en una compilación publicada en el año 2013 bajo el título Imágenes y discursos sobre los jóvenes) también hace referencia a un trabajo etnográfico realizado en dos escuelas secundarias de la misma ciudad.

Siguiendo con el detalle de los antecedentes, es pertinente hacer mención a una conferencia de Silvia Bleichmar brindada en el año 2006 en el Observatorio Argentino de Violencia en las Escuelas, publicada dos años más tarde bajo el título Violencia social violencia escolar. Si bien esta conferencia no hace referencia a un estudio en particular, es decir, no pretende dar cuenta de un proyecto de investigación específico, su entendimiento de la violencia como problemática social y su articulación con el debilitamiento de la palabra y con la ruptura de las relaciones asimétricas entre jóvenes y adultos nos invita a tenerla en cuenta y a leer atentamente sus reflexiones. Con un coherente enfoque interdisciplinar en el que articula argumentos sociológicos y psicoanalíticos, Bleichmar 
advierte que, a pesar de que el problema de la violencia en las escuelas no es una novedad en términos históricos, sí lo son las manifestaciones que se incluyen hoy en día bajo este fenómeno: "Todos estamos profundamente preocupados por las nuevas formas que toma la violencia en la Argentina: no solamente hay una mayor cantidad, sino que también aparecen nuevas formas de violencia que no existían anteriormente" (Bleichmar, 2008: 26).

Con un explícito rechazo a la criminalización y a la individualización de la violencia, la autora retrotrae y vincula la problemática con una serie de eventos trascendentes en la historia argentina reciente. En primer lugar hace referencia a la última dictadura militar y a los abusos de autoridad que caracterizaron a dicho período. Lejos de tratarse de un asunto resuelto, las heridas que dejó el golpe se encuentran vigentes hoy en día, afectando de manera determinante las relaciones de autoridad entre adultos y jóvenes. Sería por eso que, "en la Argentina, a partir de los modos en que se ejerció el poder despótico durante muchos años, hay una cierta desvalorización de la asimetría" (ibíd.). El segundo evento caracterizado por Bleichmar como uno de los factores que influyeron en el actual problema de la violencia es la década de 1990 y el proyecto neoliberal que caracterizó a dicha etapa. Bajo la premisa de la privatización, la globalización y las "recetas" impuestas por organismos financieros internacionales, este momento se caracterizó por un vaciamiento generalizado. Estas trasformaciones, lejos de pasar inadvertidas, afectaron de manera dramática el valor de la palabra, ya que esta fue empleada de manera sistemática para mentir y encubrir: "la palabra se degradó en Argentina. Se utilizó para encubrir: las metáforas que se usaron en la dictadura y en los noventa eran una degradación del lenguaje" (ibíd.: 32). A este período le corresponden una serie de problemas evidenciados en todos los sectores sociales: corrupción, soborno, delincuencia, desempleo, pobreza, huelga, represión, violencia, son algunas de las principales marcas de la época. En tercer orden la autora habla de una profunda crisis institucional, refiriéndose indirectamente a la habitualmente denominada "crisis del 2001" y a las consecuencias socio-políticas que sucedieron a tal estallido. ${ }^{8}$ Con el desplazamiento

\footnotetext{
${ }^{8}$ Aquí es pertinente también hacer mención a los estudios de Kornblit, particularmente a la obra que dirige bajo el título Violencia escolar y climas sociales; en la misma la autora atribuye el incremento de las manifestaciones de violencia a una serie de procesos socio-culturales acontecidos en la historia reciente del país. En sus palabras: "Al igual que otras circunstancias vinculadas con el aumento de episodios agresivos, este hecho debe entenderse a partir de la mayor fragmentación social y de las desigualdades sociales que se han instalado en nuestro medio en las últimas décadas. [...] La ausencia de un sentimiento consensuado del
} 
del valor simbólico de las instituciones comenzaron a regir otros valores. Una lectura analítica de esta conferencia nos permite identificar tres elementos propios de esta reconfiguración de la sociedad argentina contemporánea: la desubjetivación, la inmediatez y la ausencia de futuro. Estas categorías serán utilizadas a lo largo de todo nuestro trabajo.

\section{El diseño de la investigación}

La tesis se compone de cinco capítulos. Estos se desprenden directamente del planteamiento de la hipótesis, es decir, que en cada apartado se intentará desglosar, analizar y ampliar cada uno de los elementos mencionados en la conjetura inicial.

De acuerdo a la estructura planteada, en el primer capítulo se procurará mostrar lo que acontece hoy en día en las escuelas secundarias con respecto a la cuestión de la violencia. Siguiendo este objetivo, se intentará llevar a cabo un paneo inicial del problema atendiendo a tres fuentes de información: los documentos estatales, la bibliografía especializada y los testimonios brindados por los informantes. La intención de realizar este racconto o estado del arte es poner de relieve algunas de las representaciones que giran en torno a la problemática estudiada: la naturaleza de los acontecimientos comúnmente enmarcados en esta temática, la responsabilidad -o irresponsabilidad- del estado, el rol (supuestamente protagónico) de los jóvenes, el tratamiento sensacionalista de los medios masivos de comunicación y la (aparentemente creciente) percepción del fenómeno en el interior de las escuelas, entre otras. Como veremos a lo largo del capítulo, el asunto de la violencia en las escuelas se encuentra impregnado por una serie de preconceptos y señalamientos tendientes a la criminalización y a la estigmatización que, lejos de enfocarse en la resolución del problema, crean una atmósfera de ascendente confusión. Los efectos de este malentendido imposibilitan determinar con precisión las características del fenómeno -en otras palabras, nadie sabe describir con claridad lo que se suele denominar "violencia escolar" o "violencia en las escuelas"-.

En segundo término nos adentraremos de lleno en el componente de la hipótesis denominado "reconfiguración de la autoridad"; aquí veremos cómo la autoridad que históricamente estuvo asociada al rol del adulto hoy se encuentra en un proceso de evidente

nosotros hace que los conflictos se monten sobre el escenario de percibir a los que no pertenecen al propio grupo como extraños y eventualmente enemigos" (Kornblit, 2008: 11). 
crisis. Esto repercute de manera directa en el ámbito educativo, no solo porque los docentes encuentran problemas a la hora de desarrollar sus tareas, sino porque en muchos casos -no todos- han optado por eludir o desatender su lugar como adultos y como educadores. Este movimiento arroja dos consecuencias: se libera a los jóvenes de las ataduras que supone la presencia de una autoridad que determina qué se puede hacer y qué no y, consecuentemente, se deja a las nuevas generaciones a merced de una sociedad atravesada por un creciente problema de violencia y nihilismo. El "choque" sin protección de los jóvenes con el mundo supone adentrarse sin respaldo en una sociedad en la que se exacerban valores como el individualismo, la competencia, la autosuperación, la intolerancia, el egoísmo y el triunfalismo. El resultado de estos condicionantes -y de la ausencia de una asimetría protectora- es que los nuevos se ven obligados a crear su propio mundo: un lugar inestable en el que las leyes tradicionales son sustituidas por el dominio del más fuerte, constituyendo un espacio autorregulado que, en términos arendtianos, podría caracterizarse como una tiranía.

En el tercer capítulo nos enfocaremos en el segundo factor que, entendemos, desencadena y agrava el problema de la violencia en contextos escolares: "el debilitamiento del lenguaje". En la autorregulación de los jóvenes operan códigos que se construyen por fuera del lenguaje -o al menos por fuera de un lenguaje compartido con el resto de los actores escolares-, y esto abre las puertas a la construcción de un mundo propio, incluso bajo la mirada de los adultos (quienes, en ocasiones, no cumplen ninguna función más allá del monitoreo y la intervención ante acontecimientos violentos con consecuencias graves). Estos códigos se erigen en torno a la experimentación del cuerpo desde su condición meramente orgánica, esto es, la constante y creciente búsqueda de sensaciones provenientes del estímulo físico (dolor, vértigo, adrenalina, excitación, etcétera). Aquí es posible introducir la violencia como un modo de experimentar el cuerpo mudo, ya que -en tanto acción comúnmente exteriorizada en el plano físico- este recurso evidencia, además de una peligrosa autonomía, la imposibilidad de recurrir a medios simbólicos para relacionarse con otros. Emplear la violencia en lugar del lenguaje pone en peligro el propio cuerpo, al someterlo a situaciones en las que puede resultar herido, y también el cuerpo del otro, ya que las acciones violentas tendientes a ocasionar un daño tienen como objetivo final la invalidación o el aniquilamiento. 
Habiendo recorrido las principales aristas de la hipótesis, en el cuarto capítulo proponemos llevar adelante un análisis de las medidas que se suelen llevar a cabo en las escuelas seleccionadas con respecto a la temática en cuestión. Tanto la revisión de bibliografía especializada como la información recolectada en las entrevistas demuestran la coexistencia de dos tendencias contradictorias: por un lado se interpreta a la escuela como un espacio previsto para la civilización y pacificación de las nuevas generaciones, es decir, como una institución que "por su naturaleza social" es considerada enemiga de la violencia; a esta tendencia la denominaremos optimista. Por otro lado, la escuela también es caracterizada como un lugar altamente beligerante, en el que se evidencia cierto descontrol que acaba por desencadenar y agravar hechos asociados a la violencia; a esta tendencia la designaremos fatalista. En este capítulo se desarrollarán las características de una y otra tendencia, y además se pondrán en cuestión algunos elementos propios del sistema educativo público que, por su naturaleza burocrática e impersonal, crea escenarios en los que el automatismo, la irreflexión y lo absurdo se combinan para crear y acentuar problemáticas asociadas en algún punto con la violencia.

En el quinto capítulo nos proponemos recuperar y ampliar una de las categorías más recurrentes en los estudios dedicados a la violencia en las escuelas: la dimensión física de la violencia, y lo que podría considerarse su opuesto o alternativa inmaterial, es decir, el uso argumentado de la palabra y la inscripción del cuerpo en un orden simbólico. Persiguiendo este objetivo, en la última parte del capítulo nos proponemos explorar, en sintonía con algunas reflexiones de Elias y Dunning (1992), las posibilidades que ofrecen el juego y el deporte, en tanto prácticas educativas favorables para la "des-fisicalización” del cuerpo. Siguiendo esta línea, proponemos centrar la atención en tres aspectos centrales: la identificación de los usos del cuerpo legítimos e ilegítimos, la constitución de lazos sociales y el reconocimiento de las reglas.

En función del carácter social del fenómeno, y entendiendo que sería impreciso adentrarse en el problema de la violencia en las escuelas al margen del análisis de los condicionamientos histórico-políticos y la perspectiva de los actores, el presente trabajo adhiere a una metodología de orden cualitativa. Atendiendo los criterios propuestos por Vasilachis de Gialdino (2006) para el desarrollo de este tipo de estudios, es preciso mencionar que la recolección de datos se basó en el empleo en tres recursos: la realización 
de entrevistas individuales y grupales, la revisión de bibliografía especializada y la consulta de diversos documentos de carácter oficial -más específicamente, leyes y guías procedimentales-.

En relación al aspecto comúnmente denominado etnográfico, la tesis incluye datos recolectados en tres escuelas secundarias ubicadas en la ciudad de La Plata y sus inmediaciones, entre los años 2011 y 2015. ${ }^{9}$ La selección de las instituciones se realizó siguiendo el criterio de diversidad geográfica descripto por Vasilachis de Gialdino (2006) para el estudio de casos múltiples. Continuando con esta línea, las escuelas seleccionadas se encuentran emplazadas en distintos barrios. En primer lugar, se seleccionó una escuela secundaria situada en el centro de la ciudad de La Plata, luego otra institución del mismo nivel educativo, pero separada de la primera por unos cinco kilómetros con dirección al norte, y por último una tercer escuela también de nivel medio y emplazada en el partido de La Plata, pero alejada del casco urbano por unos diez kilómetros en dirección al noroeste, en una de las zonas donde operó el Ferrocarril Provincial (luego Ferrocarril General Belgrano). Las escuelas secundarias mencionadas serán referenciadas de manera abreviada como "escuela del centro", "escuela de la periferia norte" y "escuela del barrio ferroviario". Consideramos que una breve descripción de las condiciones en las que se enmarcan estas instituciones puede servir para comprender mejor las características de la población que asiste a los establecimientos en los que se llevó a cabo la presente investigación (procurando conservar el anonimato de la institución y de los informantes).

La "escuela del centro" se caracteriza por estar situada a unas pocas cuadras del corazón del casco urbano de La Plata, es decir, la Plaza Moreno y sus edificios aledaños

\footnotetext{
${ }^{9}$ Consideramos que la relevancia de la precisión temporal es relativa, ya que en esta clase de estudios, al centrar la mirada en la escuela contemporánea en términos generales y al tener en cuenta la información brindada por los informantes, la atención está dirigida a la experiencia relatada por el entrevistado sobre los últimos años en la institución en la que fue consultado (desatendiendo la fecha exacta de los eventos rememorados). Pese a esta aclaración, no podemos pasar por alto el hecho de que durante los años en que se llevaron a cabo las entrevistas fue posible observar una creciente preocupación del estado por la cuestión de la violencia en escenarios educativos -la promoción de numerosas políticas públicas vinculadas a esta temática son evidencia de lo mencionado. El año 2014 es particularmente destacable en este aspecto, ya que a la sanción de la Ley 26.892/13 de "Promoción de la convivencia y abordaje de la conflictividad social en las instituciones educativas", le sucedieron una serie de documentos -cofinanciados por el estado y UNICEF-, destinados a mitigar la violencia en contextos educativos. Poco a poco, durante el período en el que se llevaron a cabo las entrevistas (2011-2015), fue posible advertir que hablar de la violencia en las escuelas dejó de ser considerado un tema tabú, en el que solo unos pocos se atrevían a indagar, para pasar a formar parte de una de las principales preocupaciones contemporáneas en materia educativa.
} 
(dedicados a la administración y el gobierno del municipio y la Provincia de Buenos Aires). Debido a su locación urbana, esta institución cuenta con todos los servicios y con numerosos accesos en lo que refiere al transporte público. Por esta misma razón, el establecimiento recibe alumnos provenientes de barrios muy diversos -tanto del casco urbano como de la periferia-, lo que a su vez revela la presencia de una matrícula sumamente heterogénea. Asimismo, la escuela se encuentra rodeada por el principal centro comercial de la ciudad, lo que la sitúa en un lugar de constante tránsito peatonal y automovilístico y la deja vulnerable a interrupciones frecuentes en el tráfico y al sonido estruendoso que suele acompañar los reclamos y las movilizaciones que regularmente se concentran alrededor de sus calles. Desde el aspecto edilicio, la escuela evidencia claras muestras de deterioro como el desprendimiento de mampostería, filtraciones de agua y roturas en el mobiliario escolar (producido no solo por el uso corriente, sino también por el daño deliberado).

La "escuela de la periferia norte", por su parte, también se encuentra ubicada en una zona urbanizada y de fácil acceso, aunque, si tomamos "la escuela del centro" como punto de referencia, la frecuencia del transporte público es significativamente menos. El barrio en el que se enmarca la institución, si bien cuenta con todos los servicios, muestra grandes diferencias en lo que respecta a la infraestructura de los hogares, es decir, en una misma manzana se pueden observar tanto casas humildes construidas con materiales precarios, como inmuebles costosos con más de una planta y varios accesos para vehículos. En cuanto a la disposición del espacio físico, el colegio comparte el sector de la entrada y el patio principal con una escuela primaria, situación que genera roces y desencuentros entre los diferentes miembros de la comunidad escolar. ${ }^{10}$ En cuanto a las instalaciones, el

\footnotetext{
${ }^{10}$ La disposición espacial prevista para los tres primeros años de la educación secundaria pública (división hasta hace poco denominada Educación Secundaria Básica y actualmente conocida como Ciclo Básico), en muchos casos comenzó funcionando -y actualmente lo sigue haciendo- como una subdivisión dentro de un edificio originalmente dispuesto para el funcionamiento de una escuela primaria. Esta repartición de espacios -inaugurada en los años noventa a partir de la Ley Federal de Educación 24.195-, lejos de realizarse de manera gradual y planificada, condujo a un desconcierto entre las responsabilidades provinciales y nacionales en lo concerniente a la administración de las escuelas. Entre las consecuencias que se sucedieron a esta reforma, la superpoblación de estudiantes concentrados en establecimientos con una capacidad limitada fue una de las constantes que, lejos de resolverse, pareciera haberse recrudecido con el paso de los años. En suma, la convivencia de alumnos, docentes y autoridades de diversos niveles educativos bajo el mismo techo genera, cotidianamente, varios conflictos mayormente producidos por la saturación de los espacios físicos y por numerosas confusiones a la hora de asumir responsabilidades.
} 
establecimiento revela un desgaste severo, situación que se agravó significativamente a partir de las inundaciones del año 2013, afectando mayormente la situación estructural de las paredes y el funcionamiento de los baños.

La "escuela del barrio ferroviario" se enmarca en una zona semi-rural en cuyo contexto inmediato se entremezclan los restos de un predio que antiguamente funcionó como estación de trenes (actualmente en estado de abandono) con una serie de terrenos destinados al trabajo agrícola (fundamentalmente pequeñas parcelas con construcciones precarias). El colegio cuenta con luz y agua potable y con un único servicio de transporte público que lo comunica con el centro de La Plata (con una frecuencia considerablemente menor en comparación a las escuelas anteriormente descritas). El barrio cuenta con una delegación municipal y un centro comercial propio, lo que le otorga cierta autonomía en términos de administración, y posee una sola calle principal (la cual finaliza en la antigua estación). La limitada cantidad de accesos y la posibilidad de contar con una delegación municipal convierten a la zona en algo así como un pueblo o una localidad pequeña con un ritmo propio, es decir que, en determinados días y horarios, el barrio repite la misma rutina. Por otra parte, el sector en cuestión se encuentra rodeado por tres countries o barrios privados, lo que revela una diferenciación tajante en términos de vivienda, servicios y hábitos entre quienes habitan dentro y fuera de las zonas cerradas. No es un dato menor el hecho de que los propietarios de los barrios privados no suelan enviar sus hijos a la escuela pública más cercana. Por el contrario -y evidenciando una marcada disparidad material a pesar de la cercanía geográfica-, la matrícula que frecuenta "la escuela del barrio ferroviario" suelen ser los hijos de trabajadores dedicados mayormente a la agricultura y a la construcción, quienes, paradójicamente, también suelen realizar labores de mantenimiento y albañilería en el interior de los countries mencionados. En cuanto a la distribución del espacio, la escuela secundaria comparte el edificio con una escuela primaria y, si bien los distintos niveles poseen ingresos separados, el hecho de que la entrada y acceso a los baños se encuentren al aire libre ocasiona que los días de lluvia los alumnos del nivel secundario se entremezclen con los de nivel básico (situación incómoda para los dos sectores). En cuanto al estado y las características de la infraestructura, si bien el establecimiento resulta considerablemente pequeño para la cantidad de estudiantes que 
asisten regularmente, su estado general es bueno, no evidenciando daños a primera vista (como sí ocurre con las otras escuelas seleccionadas).

Más allá de las características propias de cada zona, si tomamos el nivel socioeconómico y la organización familiar como parámetro de referencia, nos atrevemos a afirmar que los rasgos generales de la población que asiste a las tres escuelas seleccionadas no poseen grandes variaciones. A estas instituciones suelen asistir los hijos de trabajadores en relación de dependencia - tanto pública como privada- con escasos recursos y con un poder económico limitado. Asimismo, estos colegios han captado la gran mayoría de los descendientes de inmigrantes: estos sectores generalmente provienen de países limítrofes en busca de oportunidades laborales, y en su mayoría se dedican a la construcción, al mantenimiento de los servicios públicos y a la producción agrícola, exponiéndose a trabajos físicamente agotadores y a condiciones de salubridad mínimas. La diversidad de origen y de las actividades desarrolladas por las familias evidencian la presencia de poblaciones heterogéneas que, a pesar de sus diferencias, asisten a la escuela con las mismas dificultades: vivienda, alimentación, trabajo, salud, higiene, seguridad, constituyen algunas las principales carencias de los sectores que asisten hoy a estos colegios. ${ }^{11}$

Con respecto a la organización familiar, en general encontramos la permanencia de estructuras comúnmente denominadas tradicionales, donde los roles asignados a cada género suelen sostenerse de manera férrea e incuestionada. En esta preestablecida distribución de funciones, las mujeres suelen encargarse del mantenimiento del hogar y el cuidado de los hijos, incluyendo, el acompañamiento en su educación. En muchos casos, y de acuerdo a la organización del trabajo, algunas madres asisten también a hijos de otras familias, hecho que también muestra el interés por generar redes para sostener y acompañar la escolaridad, incluso en contextos difíciles. ${ }^{12}$

\footnotetext{
${ }^{11}$ Las falencias que pueden advertirse en los barrios periféricos dónde se encuentran la "escuela de la periferia norte" y "la escuela del barrio ferroviario" no difieren de las observadas en otras zonas alejadas del casco urbano de La Plata. La investigación desarrollada por Ortale, Eguía y Rausky (2018) sobre la condición del barrio José Luis Cabezas coincide con la nuestra en numerosos puntos, sobre todo los referidos a la situación de vulnerabilidad -habitacional, laboral, de ingresos, etcétera- que afecta cotidianamente a las poblaciones más alejadas. Es preciso aclarar que la población que asiste a la "escuela del centro" no queda exenta de las dificultades mencionadas: aunque la institución se encuentre ubicada en una zona con servicios e infraestructura apropiados, gran parte de los alumnos proviene de lugares afectados por las dificultades marcadas.

${ }^{12}$ El papel de las mujeres en lo que refiere al cuidado de las necesidades básicas y el acompañamiento en la educación de los más jóvenes es una constante que se replica en las tres instituciones relevadas. Esta situación también es advertida por Ortale, Eguía y Rausky: "en lo que respecta a la realización de actividades
} 
Con respecto a los informantes, la muestra se compone de once adultos con diversas ocupaciones dentro de las escuelas seleccionadas (docentes, directivos y miembros de Equipos de Orientación Escolar) y treinta y un alumnos (cuyas edades varían entre los doce y dieciséis años de edad al momento de realizar las entrevistas grupales). El criterio para la selección de los informantes se basó en las características propias del objeto de estudio: al asumir que la violencia se trata de un problema de carácter relacional, se consideró menester atender el punto de vista de los diversos actores comúnmente vinculados a la problemática. Con el fin de recolectar datos en un período no mayor a cuatro años, ${ }^{13}$ se planificó, para cada escuela, una entrevista grupal con alumnos, una entrevista grupal con los respectivos Equipos de Orientación Escolar (E.O.E.) y una entrevista individual con una autoridad y un docente. ${ }^{14}$

Si bien en términos generales el plan original pudo llevarse a cabo, los diálogos previstos con los miembros de los Equipos de Orientación Escolar tuvieron que replantearse debido a múltiples desencuentros y a la imposibilidad de reunir a todos los miembros en un lugar y momento apto para llevar a cabo una entrevista. Por lo expuesto, la muestra de los E.O.E. se redujo a una entrevista grupal con dos representantes de la "escuela de la periferia norte" y, aunque no fue planteado en el esquema original, se incluyó una entrevista grupal con tres integrantes de un equipo distrital encargado de asistir a las escuelas cuando ocurren hechos traumáticos de diversa naturaleza (peleas con secuelas físicas y materiales graves, suicidios, casos severos de adicciones, etcétera). ${ }^{15}$ Dado que su

domésticas y de cuidado, se corrobora lo que diferentes estudios en la materia vienen sosteniendo respecto de la división intrafamiliar del trabajo en sectores vulnerables: la mayor carga de estas actividades suele recaer en las mujeres. De la amplia gama de actividades que en el ámbito doméstico se realizan, las mujeres se encargan principalmente de las tareas de limpieza y actividades adyacentes, la preparación de la comida y el cuidado de los niños. Los varones participan en mayor medida en las tareas de mantenimiento de la vivienda (construcción o refacciones) y comparten con las mujeres -aunque en menor medida que ellas- la realización de trámites y compras" (2018: 51). Este compromiso de las mujeres con la atención y la educación de los más chicos constituye una labor fundamental ya que -pese a numerosas dificultades- contribuye con la permanencia de los jóvenes en el sistema educativo.

${ }^{13}$ El plazo estipulado corresponde con el desarrollo de las becas de inicio y finalización de doctorado concedidas por la Universidad Nacional de La Plata y el Consejo Nacional de Investigaciones Científicas y Técnicas.

${ }^{14} \mathrm{El}$ formato de las entrevistas fue diagramado siguiendo el esquema de las "entrevistas estandarizadas no programadas" (Valles, 1999: 187). Esto supuso la confección inicial de un listado de preguntas que posteriormente fueron acomodándose y adaptándose de acuerdo a las características de los entrevistados. Véase "Esquema general de preguntas para la realización de entrevistas", en el apartado correspondiente a Anexos, págs. 190-191.

${ }^{15}$ El equipo mencionado será nombrado a lo largo de la tesis, de manera genérica, como Equipo Distrital de Infancia y Adolescencia. 
jurisdicción es pertinente con el recorte geográfico y, desde el punto de vista teórico, sus intervenciones suelen estar asociadas a episodios de violencia, su inclusión fue considerada pertinente. Asimismo, la realización de esta entrevista en el año 2015 supuso el cierre del "trabajo de campo", ya que fue posible establecer cierta "saturación" (Glaser y Strauss, 1967), es decir, que dada la variedad y profundidad de temas relevados sería muy difícil, a partir de ese punto, hallar respuestas nuevas y significativas para el desarrollo de la investigación.

Siguiendo con la fundamentación de las decisiones metodológicas, es preciso aclarar que la elección del nivel secundario se basó en la reiteración de "casos de violencia" que los medios de comunicación suelen atribuir a este recorte del sistema educativo. Según Southwell y otros:

En los últimos años, la situación de la "escuela media" ha sido objeto de innumerables debates. Los diagnósticos más extendidos, con amplia repercusión en los medios de comunicación, hacen referencia a su "pérdida" de funciones, que la alejaría de sus mandatos fundacionales (2015: 311).

Además, las dificultades que atraviesan este nivel representan un desafío para el ejercicio de la investigación educativa; creemos que la escuela secundaria constituye, por estos tiempos, un campo que, pese a que se muestre reticente, requiere análisis, problematizaciones, replanteamientos, reflexiones, revisiones, aportes, críticas y sugerencias. De acuerdo con Tiramonti y Montes, "la escuela secundaria constituye una preocupación compartida y frecuente tanto en el campo de la investigación como de las políticas educativas, y hoy resulta casi un lugar común afirmar que el nivel medio es uno de los más críticos" (2009: 9). En este sentido, la selección del nivel también se realizó con la esperanza de construir alternativas significativas que, en cierta forma, reivindiquen la función simbólica de la escuela pública secundaria.

Para cerrar la introducción, consideramos oportuno reforzar uno de los principios propuestos por Vasilachis de Gialdino (2006) para el desarrollo de la investigación cualitativa, esto es, la construcción de un aporte, una creación significativa que evidencie una lectura propia, crítica y reflexiva a partir de la información recabada. A fin de no agotarse en una mera descripción de acontecimientos, creemos que el trabajo del investigador involucra el debate constante con las teorías vigentes, profundizando, refutando, modificando o reelaborando hipótesis a partir de su propio punto de vista. Sobre este rol "creador" del investigador, Morse propone: 
Para que la tarea de investigación constituya un aporte, es necesario agregar a las palabras de los actores algo adicional; sea una síntesis, sea una interpretación, sea el desarrollo de un concepto, un modelo, una teoría (Morse, en Vasilachis de Gialdino, 2006: 27).

Siguiendo esta línea, este trabajo adhiere a los esfuerzos de la comunidad académica por brindar a esta temática una mayor exactitud y precisión teórico-metodológica o, en términos de Kaplan, por "comenzar a construir el problema de la violencia en la escuela desde el campo científico” (2015: 23) ¿Qué significa esto? Fundamentalmente avanzar en la creación de herramientas teóricas y empíricas para develar aquellas construcciones que rodean y dan forma al objeto de estudio, analizar las direcciones que toma, exponer los preconceptos que suelen influir de manera tácita, estudiar las conductas de los actores comúnmente involucrados, y finalmente, esbozar estrategias de intervención para disminuir sus efectos destructivos. 


\section{Capítulo 1: Las presuntas manifestaciones del fenómeno}

La escalada de los actos de violencia preocupa porque hace patente la descomposición interna de la cohesión social. Las sociedades atravesadas por la violencia, la fragmentación y la disolución de los vínculos de confianza y respeto por los otros (los extranjeros, los diferentes, los desposeídos; y en los últimos tiempos se extiende la desconfianza hacia los propios miembros del grupo) tenderán a fabricar individuos con poca capacidad de regular sus emociones violentas.

Carina Kaplan (2009).

\subsection{Un problema del que todos hablan}

En el presente capítulo se intentará exhibir de manera crítica aquellas manifestaciones que los agentes educativos, tanto jóvenes como adultos, suelen identificar como "violentas". Persiguiendo este objetivo, se llevará a cabo un paneo inicial del problema atendiendo a tres fuentes de información: los documentos estatales, la bibliografía especializada y los testimonios brindados por los informantes. La intención de este racconto o estado del arte es poner de relieve algunos de los elementos que conforman la problemática: la intervención del estado, el relevamiento de hechos, el rol -supuestamente protagónico- de los jóvenes, la cobertura de los medios masivos de comunicación y la creciente percepción del fenómeno en el interior de las escuelas. Como veremos a lo largo del capítulo, el asunto de la violencia en las escuelas se encuentra impregnado por una serie de preconceptos y señalamientos tendientes a la criminalización y a la estigmatización que, lejos de enfocarse en la resolución del problema, alimentan una atmósfera determinada por la controversia y la confusión. Los efectos de este malentendido impiden determinar con precisión una definición del fenómeno; en otras palabras, nadie sabe describir con claridad lo que se suele denominar "violencia escolar" o "violencia en las escuelas". De acuerdo con Castorina y Kaplan:

No puede haber -por razones de principio epistemológico- un conocimiento completo ni definitivo de la violencia, particularmente de la vinculada a las instituciones educativas. Debemos aceptar el carácter parcial de las caracterizaciones y la ausencia de certezas (2015: 33). 
Reflexionar sobre la violencia en ámbitos educativos públicos dependientes de la Provincia de Buenos Aires se trata de un ejercicio relativamente reciente. Si bien esto no significa que el problema no existiera con anterioridad a los últimos quince o veinte años, este tema no era considerado una prioridad en las agendas educativas nacionales ni provinciales. Hoy, por el contrario, nos encontramos con una creciente y por momentos exacerbada visibilización de la cuestión.

Cuando decidimos rastrear el fenómeno en algunas escuelas secundarias (más precisamente, en tres establecimientos públicos), rápidamente pudimos evidenciar (tanto en los testimonios de los adultos como en los de los jóvenes) la permanencia de una serie de críticas -acentuadas en los últimos tiempos- sobre este nivel educativo. Parafraseando a Southwell (2018), la escuela secundaria ha vivido décadas de cambios y cuestionamientos, junto a una caracterización frecuente de crisis, que se hace presente ya durante la segunda mitad del siglo XX. Es innegable que en la actualidad existe una caracterización marcadamente negativa de las escuelas medias estatales, la cual pareciera agravarse con el paso del tiempo. Con frecuencia, la escuela pública es identificada hoy como el lugar de los violentos, los excluidos, los pobres, los inmigrantes, construcciones que, en Argentina, arrastran una fuerte carga social negativa que se materializa en múltiples -y a veces inconscientes- prácticas discriminatorias. De acuerdo con Garriga Zucal, "en nuestra sociedad nadie desea ser catalogado como violento. Por ello, la definición de algo o alguien como violento actúa como impugnación sobre las prácticas de ajenos y distantes" (2016: $10)$.

En los últimos años, particularmente entre el 2006 y el 2015, el Ministerio de Educación de la Nación destinó fondos para el financiamiento de proyectos de investigación abocados a la cuestión de la violencia (ejecutados a través de organismos de investigación, universidades y observatorios). Esta preocupación del estado por el asunto de la violencia en las escuelas se explicita también en la sanción de leyes vinculadas directa o indirectamente a la temática, y en la publicación de guías destinadas a orientar al conjunto de la población escolar en lo referente al tratamiento del problema. Tal es el caso de la Guía federal de orientaciones para la intervención educativa en situaciones complejas relacionadas con la vida escolar, la cual, entre sus objetivos, establece “interpretar y analizar los hechos de violencia dentro de la escuela desde una perspectiva ética, 
entendiendo que toda violencia en la escuela, ejercida por cualquiera de sus actores es un hecho de injusticia" (Ministerio de Educación de la Nación, 2014: 7). ${ }^{16}$ A nivel provincial también se evidencia una creciente preocupación por la cuestión de la violencia, como lo demuestran la constitución de organismos intervinientes y la publicación de una serie de documentos cofinanciados por UNICEF. ${ }^{17}$

Con una marcada intencionalidad procedimental, uno de los documentos provinciales referido a la temática define a las situaciones de violencia -de un modo bastante escueto- como "aquellas situaciones que remiten al uso de la fuerza" (DGCYEUNICEF, 2014: 52). El mismo escrito introduce el robo, las lesiones, las extorsiones y el uso de armas como acciones enmarcadas bajo el rótulo de "violencias en contextos escolares", y establece una serie de intervenciones específicas para tratar este tipo de episodios. Estas intervenciones van desde la desarticulación inmediata de una pelea hasta la elevación del caso al Consejo Institucional de Convivencia; ${ }^{18}$ en casos graves (con muertos o heridos), el documento sugiere la elevación del mismo a las autoridades distritales y judiciales. Si bien el modo de proceder conlleva cierta estandarización -producto de un abordaje procedimental más orientado a instruir al personal docente respecto de las responsabilidades legales-, lo trascendente es que la cuestión de la violencia ingresa a la

\footnotetext{
${ }^{16}$ La preocupación del estado por la cuestión de la violencia en contextos escolares puede evidenciarse en la sanción de la Ley 26.892/13 de "Promoción de la convivencia y abordaje de la conflictividad social en las instituciones educativas". Entre sus líneas no solo se destaca el reconocimiento de la problemática en términos generales, sino que además se propone como objetivo "garantizar el derecho a una convivencia pacífica, integrada y libre de violencia física y psicológica" (Congreso de la Nación Argentina, 2013: 2).

${ }^{17}$ Las guías a las que se hace referencia son: Violencias y escuelas. Otra mirada sobre las infancias y las juventudes y Guía de orientación para la intervención en situaciones conflictivas y de vulneración de derechos en el escenario escolar.

${ }^{18}$ A partir del año 2002, la entonces Dirección de Educación Polimodal impulsó una reglamentación en la que se dispuso que cada escuela debe consensuar sus propias normas de convivencia. Aún vigente, esta normativa prevé la constitución de un Acuerdo Institucional y un Consejo Institucional de Convivencia. La composición del consejo introduce una novedad con respecto a las normas disciplinarias precedentes, puesto que, con la intención de promover una convivencia democrática, incluye a todos los actores escolares en la toma de decisiones. El consejo debe estar compuesto por representantes de docentes, alumnos y miembros del Equipo de Orientación Escolar, y su función es la de "evaluar, deliberar y asesorar las decisiones tomadas por la Dirección de la Escuela en la aplicación de los Acuerdos Institucionales" (Dirección General de Cultura y Educación de la Provincia de Buenos Aires, 2002: 69). En la práctica (particularmente en las escuelas seleccionadas para la muestra, y teniendo en cuenta el relato de varios entrevistados), se evidencia un funcionamiento irregular que depende en muchos casos de la exclusiva voluntad del directivo principal. Por otro lado, en una investigación dedicada específicamente al funcionamiento de este tipo de normas, Osorio comunica los siguientes resultados: "el $80 \%$ de las escuelas públicas y el $60 \%$, que tenían acuerdos institucionales de convivencia, decidieron continuar con el sistema de amonestaciones (...). Al convivir ambos sistemas, uno disciplinario y el otro democrático (al menos en su formulación), se favorecen prácticas sociales de extralimitación que producen violencia" (2006: 74).
} 
agenda estatal como un asunto cuya resolución requiere que se inviertan recursos específicos. Paulatinamente, desde finales de la década de los noventa, el problema de la violencia en las instituciones educativas dejó de ser un tema aislado y circunstancial. A partir de este reconocimiento se hace extensiva la preocupación, al menos en las disposiciones de varios organismos oficiales, por las crecientes manifestaciones de fenómenos asociados -a veces con demasiada premura- a la cuestión de la violencia. ${ }^{19}$

Ahora bien, la creciente visibilización de esta problemática nos obliga a preguntarnos sobre la veracidad y aparente expansión del fenómeno: ¿se trata de un problema que efectivamente puede visibilizarse en las escuelas o es el producto de cierta construcción social basada en preconceptos y arbitrariedades? ¿Acaso el exacerbado sensacionalismo de los medios de comunicación influye sobre la percepción del fenómeno? No es azaroso que Kaplan (2009) haya titulado una publicación sobre esta temática Violencia escolar bajo sospecha. Allí, y aunque reconoce una escalada de la violencia en términos generales, cuando la problemática es trasladada al campo específico de lo escolar, la autora advierte la permanencia de una mirada judicializante y estigmatizante sobre los jóvenes. Otros autores menos cautos consideran que la problemática es "real" y que la violencia se ha apoderado por completo de los colegios. Tal es el caso de Osorio, quien sentencia: “el nivel de violencia y agresión al que están expuestos los integrantes de las instituciones nacionales es inédito. Especialmente el sistema educativo en su conjunto" (2006: 121). ${ }^{20}$ La mirada de Silvia Duschatzky y Cristina Corea, si bien excede el ámbito específicamente escolar, también evidencia cierta alarma respecto de la cotidianeidad de la violencia en la vida de los jóvenes: "la violencia se presenta como el sustrato cotidiano sobre el que construyen la subjetividad niños y jóvenes (...). Digamos que la violencia es hoy una nueva forma de socialidad" (2013: 22-23). Sobre las manifestaciones que suelen

\footnotetext{
${ }^{19}$ Atendiendo a las investigaciones de Southwell, es preciso recalcar que esta creciente preocupación del estado por legislar la cuestión de la violencia en las escuelas se enmarca en un movimiento histórico e inédito en el nivel secundario, donde la intervención de las políticas públicas -con no pocas dificultades y asuntos pendientes- expandió la cobertura de este nivel hacia sectores históricamente desatendidos. En sus propias palabras: "al menos para el caso de la escuela secundaria, la existencia de un entramado legislativo novedoso, que se desplegó de manera concomitante a la expansión de la cobertura del nivel, devela la existencia de un nuevo encuadre institucional. Resta aún mucho camino por recorrer para estudiar las interrelaciones entre las políticas públicas que impulsan la participación estudiantil y las acciones políticas que éstos despliegan en el espacio escolar" (2016: 9).

${ }^{20}$ Un poco más adelante Osorio reafirma su percepción radicalizada del fenómeno: "la educación era un valor. Que hoy está en franca decadencia y absolutamente violentado" (2006: 121).
} 
asociarse al fenómeno de la violencia en las escuelas se destaca la compilación realizada por Furlán, quién centra la atención en las siguientes expresiones:

Hurtos a la institución, vandalismo, destrucción del inmueble, discriminación, situaciones de acoso, insultos, enfrentamientos físicos, intrigas, amenazas, peleas grupales, falta de respeto a los adultos de la institución, son algunas de las situaciones que a modo de ejemplo acompañan generalmente a las reflexiones conceptuales acerca de los aspectos sociales, culturales, históricos y socio afectivos vinculados a diferentes episodios de violencia en el contexto educativo (2013: 13).

Dado que existe una gran variedad de encuentros y desencuentros en lo que refiere al reconocimiento y caracterización del problema, consideramos que sería prudente analizar lo que acontece día a día en las escuelas secundarias atendiendo las perspectivas de los actores implicados. Anticipada y resumidamente, podemos decir que en el interior de las tres escuelas medias seleccionadas hay un reconocimiento prácticamente total de la problemática. Si bien la descripción de los eventos catalogados como "violentos" y la propia definición del término "violencia" se encuentran colmadas de confusiones y arbitrariedades, ninguno de los informantes entrevistados negó la existencia del problema.

Atendiendo a la perspectiva de los adultos, en los pasillos es común oír un flujo constante de quejas por parte de padres, docentes, directivos, miembros de Equipos de Orientación Escolar, auxiliares: todos hablan del problema de la violencia y todos poseen alguna anécdota -que relatan generalmente desde la posición de víctima- que consideran representativa del problema. Así, cuando se habla del tema en una sala de profesores o en una reunión de perfeccionamiento docente -casual o previamente convocada-, las menciones a esta problemática generalmente se completan con una sumatoria de experiencias personales que se yuxtaponen en una catarsis generalizada. En suma, sea para descargar frustraciones, para compartir algún evento vivido como traumático o para acusar de "violento" a algún alumno en particular, todos los adultos presentes en la institución secundaria tienen algo para decir en relación a la violencia.

Desde la perspectiva de los alumnos el panorama no difiere en cuanto al reconocimiento del problema, la gran mayoría de los escolares entrevistados tiene algo para expresar que considera representativo del asunto comúnmente denominado "violencia escolar" o "violencia en las escuelas". Cuando se trata de un acontecimiento caracterizado por los mismos jóvenes como "violento", como por ejemplo una pelea, la mayoría identifica el origen del conflicto en un cruce de miradas, en los celos, en la envidia, en la 
nacionalidad de origen o en respuesta a una serie de actitudes estereotipadas, tales como "hacerse el gato", "mirar mal", "mirar corte piola", "hacerse el cheto", "hacerse la linda" o "hacerse la popu". ${ }^{21}$ Cuando el acontecimiento involucra a los adultos en ejercicio de la docencia, los jóvenes generalmente hablan de gritos o explicitaciones de enojo, tales como golpear un pizarrón o arrojar un objeto al suelo. En ocasiones también mencionan la intromisión de un adulto proveniente del "exterior", es decir, ajeno a los roles profesionales de la institución. En estos casos, generalmente salen a la luz diversos conflictos barriales que se suceden en las inmediaciones del colegio. Los ejemplos varían, desde una pelea de bandas por el dominio de un territorio hasta enredos con vendedores de drogas. Estos son algunos de los hechos que los alumnos identifican como violentos y que conectan en menor o mayor medida con la escuela y su contexto inmediato.

Como se viene diciendo, dada la variabilidad de casos y representaciones es muy difícil recortar el término "violencia" a una única definición capaz de agrupar los diversos hechos y puntos de vista. De acuerdo con Garriga Zucal una definición universal del término sería desatinada, "dado que aquello que se establece como violencia es el resultado de una matriz de relaciones contextualmente determinadas" (2016: 10). Adultos y jóvenes se encuentran igualmente envueltos en una confusión generalizada respecto de qué es y qué no es violencia. Dentro de esta confusión, y a pesar de los esfuerzos estatales por atender el problema, tampoco queda esclarecido cuál es el lugar de la escuela en relación al origen de los hechos comúnmente considerados violentos. Pareciera así que los procedimientos estipulados frente a un hecho catalogado como violento revelan cierto estado de confusión, el cual podría considerarse una consecuencia lógica de la indeterminación que suele acompañar todo intento de definir la violencia. ${ }^{22}$

\footnotetext{
${ }^{21}$ De acuerdo al relato de los jóvenes entrevistados, "hacerse el gato" o "mirar corte piola" son sinónimos de "provocación"; es una especie de invitación a pelear por medio de una actitud desafiante como golpear un objeto o mirar fijamente a los ojos. "Cheto" es una denominación empleada para caracterizar a aquellos que invierten esfuerzos físicos y materiales en acercarse lo máximo posible "a la moda"; dentro de esta tipología también se estaría designando a aquellos que se visten con indumentaria de primeras marcas. "Hacerse la linda" es una frase empleada generalmente por el género femenino para señalar a alguna joven que encaja con los estándares más altos de belleza. "Popu" significa "hacer cosas para agradar a los demás", inclusive participar de una pelea.

${ }^{22}$ Debido a las dificultades asociadas a la definición de la violencia, acaso sea oportuno analizar brevemente su recorrido etimológico. El término violencia deriva de vis, palabra latina que, entre otros significados, remite a "la violencia, la fuerza y el poder" (Corominas, 1991: 823) o al "empleo ilegítimo o ilegal de la fuerza" (Lalande, 1953: 1439). Otras definiciones de vis incluyen términos tales como: "brusquedad, ira, intensidad extraordinaria, fuera de lo natural, torcido" (Real Academia Española, 2016); "acción contra el
} 
En este resumido panorama inicial, resulta fundamental introducir dos elementos comúnmente considerados determinantes en la problemática (tanto en la bibliografía especializada como en el relato de los informantes): el lenguaje y la autoridad. Para ser más exactos, pareciera que algunos recursos simbólicos, tales como el uso persuasivo del lenguaje y el reconocimiento de la autoridad de los mayores, hoy evidencian claros signos de debilitamiento. Siguiendo la tesis arendtiana, pareciera que el rol que históricamente ocupó el adulto en relación al joven ha quedado desdibujado, y en su lugar las nuevas generaciones han sido arrojadas a su propia suerte. El resultado es un autogobierno basado en la ley del más fuerte, donde se visibilizan tanto las consecuencias de la desafiliación como la imposibilidad de apelar a mediaciones discursivas. Este tema será ampliado en el segundo capítulo.

Con respecto al lenguaje, no es un dato menor el hecho de que se hayan desencadenado fuertes cruces verbales en dos de las tres entrevistas grupales realizadas a los alumnos. Al momento de rememorar diversas situaciones conflictivas e indagar sobre los motivos que las precedieron, varios estudiantes iniciaron una serie de acusaciones y provocaciones que, lejos de avizorar una resolución pacífica, evidenciaban la permanencia de rencores y diferencias. Siendo algo exagerados, pareciera que en los momentos descriptos la palabra no cumplía ninguna función en términos persuasivos, más bien acentuaba y perpetuaba las relaciones de dominación establecidas por la fuerza. ${ }^{23}$

Las categorías desarrolladas a continuación serán puestas en diálogo constante con la información proporcionada por los informantes y las perspectivas de varios autores provenientes de distintas áreas. Este diálogo no supone hacer decir a otros qué se debe hacer frente al problema de la violencia, sino que está pensado en vistas a la formulación de

natural modo de proceder, acción de violar" (Diccionario Enciclopédico Salvat, 1957: 817); "impetuosidad, fogosidad" (Munguía, 2013: 842); "arrebatado, carácter indomable, ferocidad, semblante feroz" (Blánquez Fraile, 1975: 1841). Cabe aclarar que en algunos documentos de consulta académicos es posible hallar solo el adjetivo violento/a (del latín violentum) sin variantes en sus acepciones latinas originales, es decir, que en la totalidad de los casos se remite a vis como expresión primaria. Ampliando, podríamos decir que la violencia es una manifestación exteriorizada mayormente a través del cuerpo, una reacción o una respuesta física y automática resultante de la ausencia de recursos simbólicos. En el ámbito educativo institucional, este recurso es comúnmente utilizado para demandar el reconocimiento de una posición en un espacio en el que la ley y la autoridad escolar -interpretadas como acuerdos tendientes a asegurar una convivencia pacífica- parecieran no operar con demasiada eficacia.

${ }^{23}$ Cabe destacar que los insultos y las amenazas no se interrumpieron por intervención mía (cuando solicitaba silencio o intentaba retornar a las preguntas), sino cuando alguno de los "líderes" levantaba la voz sobre el resto amenazando a quien sostenía una postura diferente o exponiendo su punto de vista con un tono de voz considerablemente elevado. 
categorías propias. En otras palabras, no se recurrirá al campo y a una serie de pensadores para hallar soluciones, sino para reflexionar con mayor profundidad sobre los problemas específicos que atraviesan la presente tesis.

\subsection{Debates sobre los alcances del término}

Cuando se le preguntó a un grupo de alumnos de entre doce y trece años, pertenecientes a la "escuela del centro", qué significaba para ellos la violencia, estos respondieron con una gran cantidad de términos asociados: "maltrato", "burlas", "bullying”, "discriminación”, “amenazas", "insultos", "violencia sexual", "violencia de género", "violencia verbal”. En otro grupo, en el que se dieron prácticamente las mismas respuestas, un alumno concluyó el diálogo con una sencilla pero certera conclusión: "hay muchas clases de violencia".

A simple vista pareciera que la violencia, tal como es percibida por los estudiantes secundarios, no se reduce exclusivamente a lo físico, no se trata únicamente de puñetazos y patadas. Sus relatos también evidencian la presencia de una violencia "no física", a la que se refieren utilizando una serie de conceptos ampliamente difundidos en textos escolares y medios de comunicación.

Los adultos tampoco coinciden en una única interpretación de la violencia. Si bien todos refieren a acciones de carácter físico, muchos mencionan también, en menor o mayor medida, la presencia de una violencia "no física". En este sentido un docente expuso:

Nosotros lo que tratamos de evitar es la violencia física, porque sabemos lo que origina la violencia física. Ahora, si podemos evitar la violencia psicológica sería lo ideal y para eso el docente está en un compromiso importantísimo con la violencia [...]. A veces los gritos se escuchan, y un grito hoy pertenece a la violencia [...], cuando vos le gritaste a un alumno no se lo olvida jamás, es como si le hubieras pegado, es una forma de recibir un cachetazo (profesor en Construcción de la Ciudadanía, "escuela del centro").

De acuerdo al relato del docente entrevistado, la "violencia física" es una manifestación preocupante, algo que debe evitarse; pero hay otras manifestaciones posibles de la violencia, tales como "el grito" o "la violencia psicológica", que también requieren atención. $^{24}$

Los alcances de la violencia son un tema recurrente en este tipo de estudios. Los

\footnotetext{
${ }^{24}$ Kaplan adhiere a un concepto ampliado de violencia, que no se reduzca únicamente a lo físico e incluya formas sutiles -y más frecuentes- de generar estados de intranquilidad y malestar. Atendiendo al relato de una serie de jóvenes que se reconocen víctimas de violencia, la autora afirma: "entendemos a la violencia en la escuela no solo como actos penalizables, sino también como un conjunto de victimizaciones más tenues: humillaciones, discriminaciones, faltas de respeto, formas de avergonzar, entre otras" (2009: 25).
} 
límites del término -es decir, la clase de actos que son agrupados bajo la noción de "violencia"- suelen estar plagados de controversias y desacuerdos. Tal como afirma Kaplan, "los análisis de los alcances y límites del concepto violencia no pueden permanecer tan solo en un plano meta-teórico sino que deben adquirir carácter de herramienta para comprender la realidad" (2009: 21). Ante la pregunta: ¿qué acciones pueden ser consideradas violentas?, podemos encontrarnos con un amplio rango de respuestas que, en el contexto específico de la escuela, van desde la rotura de un lápiz hasta la portación de armas. En este sentido, una integrante del Equipo de Orientación Escolar de la "escuela de la periferia norte" expresa:

En sentido estricto, por ejemplo, la violencia podría ser aquellas situaciones donde uno termina con alguna lesión, las situaciones de robo, uso de armas, extorsiones, eso sería como violencia en sentido estricto [...]. Ya en sentido más amplio podría ser... insultos, agresiones, las estigmatizaciones que se dan mucho también en las escuelas. Y bueno, este último sentido se ve con bastante frecuencia.

El abanico de posibilidades arroja ejemplos con características y consecuencias muy disímiles. Comúnmente se entiende por violencia a las agresiones causadas deliberadamente con el propio cuerpo, o en ocasiones magnificadas con el empleo de instrumentos. Nadie dudaría en incluir una cachetada, un empujón, una puñalada o un disparo bajo el rótulo de acción violenta. No obstante, muchas de las definiciones revisadas -no solo en las entrevistas, sino también en la bibliografía especializada- trascienden el carácter exclusivamente físico, material.

Algunas definiciones de violencia halladas en diccionarios y documentos académicos de consulta incluyen insultos, maltratos psicológicos o incluso la aplicación de mandatos considerados abusivos por parte de los afectados (supresión de derechos, explotación laboral, recorte de presupuestos, etcétera). Esto ocasiona una confusión generalizada respecto de los alcances del término. Una misma denominación puede hallarse en caracterizaciones tan variadas como el accionar abusivo de la policía, el enojo de un docente o el berrinche de un niño. Para Garriga Zucal:

Cada mundo social define y valora cuáles son las conductas violentas y cuándo es correcto ejercerlas. [...] La definición acerca de qué es violento y qué no lo es y, dentro de esa clasificación, el establecimiento de las conductas violentas aceptadas y las rechazadas es un campo de debates (2016: 10).

Entre las obras relevadas en relación al problema específico de la violencia en las escuelas, se destaca la perspectiva de Osorio, quien incluye bajo el paraguas de la violencia 
a las dificultades en la lecto-escritura, la comprensión de textos o los saberes mínimos requeridos para el paso de un nivel a otro: "muchos niños de cinco años no están preparados para ingresar al primer grado de la primaria, pero lo hacen. Otros no lo están para egresar de séptimo grado y ni que hablar cuando egresan del nivel secundario. Todo esto es violencia" (2006: 122). ${ }^{25}$

Volviendo a la cuestión de la multiplicidad de significados de la violencia, consideramos relevante citar el testimonio de un preceptor en el que se puede apreciar una interconexión de hechos con fundamentos debatibles:

Viene mucha gente con el tema de Conectar Igualdad. ${ }^{26}$ Para mí está perfecto que todos los chicos tengan una netbook. Pero si todos los chicos tienen una netbook y en el comedor que yo cuido, le cuentan los fideítos que les dan... eso es violencia. Que vaya un profesor a comer y que la gente de la cocina lo esté mirando a ver cuánto come, para mí es un hecho de violencia también (preceptor, "escuela del barrio ferroviario").

Si todas las acciones que señala el preceptor fuesen aceptadas, efectivamente, como manifestaciones de esa naturaleza, entonces todos los problemas que acontecen en la educación pública deberían compartir la misma denominación. En pocas palabras, si todo es violencia, nada lo es. Ahora bien, si producto de una escolarización precarizada, un joven no cuenta con los recursos simbólicos suficientes para defender su punto de vista sin necesidad de apelar a la fuerza, esto puede ser $-\mathrm{y}$ de hecho lo es- un factor desencadenante de violencia. Pero el analfabetismo funcional y la violencia no pueden nombrarse de la misma forma, porque no todos los que evidencian dificultades en la lectura cometen actos violentos. El riesgo de estas utilizaciones indiscriminadas, banales, apresuradas, es que la violencia se propague como el culpable de todos los males, designando cualquier situación problemática como "violenta" y dificultando cualquier tipo de análisis profundo de la temática. Esquivando interpretaciones marcadamente negativas o radicales en la que pareciera que "todo es violencia", en el contexto de esta investigación no consideramos actos violentos el que un joven no pueda leer fluidamente o no pueda interpretar determinados textos. En cambio, podemos adelantar que el acto violento es una

\footnotetext{
${ }^{25}$ Creemos que el fragmento citado es representativo de la multiplicidad de interpretaciones que envuelve la problemática estudiada; sin menospreciar los alcances de su investigación, en las palabras de Osorio es posible entrever cierta confusión entre la identificación de las manifestaciones consideradas violentas en un contexto determinado y las causas posibles o los factores agravantes.

${ }^{26}$ Programa impulsado por el Poder Ejecutivo Argentino en el año 2010 que promueve el acceso de todos los alumnos a equipos de computación personales y establece una plataforma web para establecer una red de trabajo virtual de alcance nacional.
} 
manifestación -exteriorizada generalmente en una dimensión física- resultante de la imposibilidad de simbolizar y de la necesidad de sobrevivir en un contexto social altamente individualista. $^{27}$

En el trabajo de Duschatzky y Corea (2013) también se hace referencia a las dificultades que rodean a la caracterización de la violencia, ya que en su experiencia la identificación de actos violentos muchas veces no coincide con la representación de los actores; dicho de otro modo, la violencia es un fenómeno visibilizado y caracterizado únicamente por los investigadores implicados. En sus términos:

La suposición general de que la violencia es la matriz explicativa de la naturaleza de las situaciones analizadas impedía ver una variación muy fuerte: el agotamiento de un tipo subjetivo, la figura del semejante [...]. La hipótesis de partida debía reformularse en los siguientes términos: los modos de vincularse con otro por fuera de la figura del semejante constituyen un hecho de violencia para una mirada externa a la situación (2013: 97-99).

Si bien el estudio de las autoras mencionadas no se centra únicamente en contextos escolares, su relectura y reinterpretación de la violencia puede operar como una advertencia metodológica válida, ya que la rápida rotulación de fenómenos muchas veces impide ver otro tipo de manifestaciones relevantes.

El señalamiento de "violento" arrastra una fuerte connotación negativa en nuestra sociedad. Dado que, desde una perspectiva eliasiana, el sujeto violento es aquel que hace tambalear el -supuestamente creciente- proceso de pacificación que caracteriza a las sociedades occidentales modernas, cualquier acción en contra de esta causa constituye una falta o una ilegalidad merecedora de un castigo y una penalización (dispuestos por el lado "bueno" de la sociedad). Así, "la amenaza que supone el hombre para el hombre se somete a una regulación estricta y se hace más calculable gracias a la constitución de monopolios de violencia física" (Elias, 1987: 456). Esto quiere decir que todo aquel que atente contra los estándares y los monopolios de violencia legítimos debe recibir el peso de una condena social por la que será señalado como un individuo "violento", "antisocial", "incivilizado";

\footnotetext{
${ }^{27}$ Es preciso aclarar que no se desconoce la relevancia de otros esquemas interpretativos en los que se incluyen conceptos tales como violencia pedagógica o violencia simbólica. Estas nociones se suelen emplear para llevar a cabo una lectura más amplia sobre el fenómeno en cuestión. La aplicación de estas herramientas conceptuales suelen fundamentarse teóricamente a partir de los trabajos de Hegel y Bourdieu, y emplearse para develar y describir el funcionamiento de una serie de redes -establecidas de manera implícita- por las que el estado, la familia y la escuela aceptan someter a las nuevas generaciones a una violencia "necesaria" -pero no obligadamente física- con el fin de llevar a cabo el proceso educativo-civilizatorio. Al respecto es recomendable el capítulo de Castorina y Kaplan "Violencias en la escuela: una reconstrucción crítica del concepto"(2015).
} 
en otras palabras, alguien que -por su naturaleza salvaje e indómita- no es digno de vivir en sociedad. Las investigaciones de Garriga Zucal -centradas en la violencia empleada como recurso "legítimo" hacia el interior de determinados grupos sociales- nos sirven para entender mejor los preconceptos negativos y las representaciones sociales que suelen acompañar la caracterización del sujeto "violento". En sus propias palabras, "lo definido como violento y negativizado ha sido expulsado de lo 'social' y parece ser ejemplo de un señalamiento patológico o anormal. [...] La violencia aparece como unidad exterior al campo social, como negación de la sociabilidad” (2015: 13). Si bien Garriga Zucal enfocó su investigación en las prácticas y los ritos que suelen evidenciarse en las hinchadas de fútbol y en las escuelas de policía, su análisis centrado en los preconceptos que suelen envolver las tipificaciones vinculadas en algún punto con la violencia nos sirve como correlato -con ciertos recaudos teóricos- para tratar de entender lo que acontece en el interior de las escuelas.

En la figura del "alumno violento" se vuelcan un montón de valoraciones negativas tendientes a la estigmatización y a la exclusión. Atendiendo a Kaplan, "los modos de nominación social y escolar en torno de los sujetos y los comportamientos tipificados como violentos no son neutros" (2009: 19). Por lo tanto, es posible afirmar que el problema de los alcances de la violencia, lejos de tratarse de un asunto irrelevante, puede leerse como una forma encubierta o sutil de llevar a cabo ciertas prácticas excluyentes. Atendiendo las advertencias de Di Leo: "cuando nos encontramos ante un problema social de definición, tenemos que preguntarnos quién está proponiendo qué definición, en cuál contexto, con qué objetivo e implicaciones personales y sociales" (2008: 17). ${ }^{28}$

Cuando la palabra "violencia" es utilizada indiscriminadamente, a modo de adjetivación o señalamiento, no solo se inviste a una persona de preconceptos negativos, sino que también se banaliza el problema tornándolo inabarcable. Si no intentamos analizar el fenómeno en profundidad, corremos el riesgo de percibir una realidad desbordada de violencia, en la que cualquier acción llevada a cabo en una escuela puede ser designada como una acción violenta y cualquier sujeto corre el riesgo de ser estigmatizado. En este

\footnotetext{
${ }^{28}$ Los preconceptos y arbitrariedades que los docentes y autoridades construyen sobre sus alumnos no operan únicamente en el plano discursivo, sino que pueden rastrearse en las prescripciones contenidas en algunos reglamentos de convivencia: "en ciertas escuelas aparecen algunas normas tendientes a la moralización de los estudiantes juzgándolos como carentes de pautas necesarias para insertarse en la escuela y posteriormente en la sociedad" (Litichever, 2012: 9).
} 
sentido, el preceptor citado más arriba agrega:

En todos los lugares dónde trabajé, escuelas primarias, de adultos, secundarias, todos, no hubo una sola... un solo lugar en mis años de trabajo donde no haya visto violencia [...]. En la escuela que yo estoy ahora, desde principio de año no pasaron dos semanas que yo no haya visto violencia. Capaz que tenía una semana tranquila y ya me sentía extraño [...]. La violencia siempre está, ya es parte de la institución.

Siendo un poco generalizadores no es extraño el hecho que hoy en día se oiga entre los pasillos de las escuelas un diálogo entre docentes en el que se adjetive a determinados alumnos de "violentos", “agresivos" o "salvajes". Es habitual, por ejemplo, en los momentos previos a la presentación de un grupo, recibir advertencias por parte de preceptores y autoridades del estilo: "cuidate de fulano que es uno de los más violentos" o "a este grupo tenés que tratarlo con mano dura". A pesar de la existencia de guías tendientes a la homogeneización de interpretaciones, la falta de límites claros ocasiona -entre otros malos entendidos- que un alumno corra la suerte de ser tildado como "violento" por docentes que, incluso sin conocerlo, pueden construir una serie de prejuicios negativos antes de intercambiar una sola palabra. Siguiendo a Di Leo:

En nuestras sociedades esa categoría [la violencia escolar] se encuentra asociada a comportamientos o palabras inaceptables, contrarios a la civilización, la humanidad, la modernidad. Por ello cada agente busca introducir en la lista de las violencias lo que vive como inaceptable en el comportamiento de los alumnos, los profesores, la escuela y las demás instituciones sociales (2008: 18). ${ }^{29}$

A fin de no caer en adjetivaciones y señalamientos derivados de una caracterización prejuiciosa, consideramos preciso aclarar algunas cuestiones semánticas, e identificar varios debates acerca de la denominación de la problemática estudiada. Algunos consideran pertinente emplear el término "violencia en las escuelas", atendiendo a la caracterización de un fenómeno, la violencia, cuyos rasgos generales se evidencian y se replican en varias instituciones educativas. Por otro lado, hay quienes prefieren la denominación "violencia escolar" para describir un tipo de violencia que acontecería únicamente dentro de la escuela y estaría protagonizada por los alumnos (los medios de comunicación se incluirían en esta categoría). Al respecto, la integrante del E.O.E. de la escuela de periferia norte, ya citada, argumenta: "si vos observás un poquitito en los medios de comunicación cómo hablan de las escuelas, es como que responsabilizan en algún punto a los jóvenes... estos jóvenes vienen a desordenar la institución escolar".

\footnotetext{
${ }^{29} \mathrm{El}$ texto entre corchetes es propio.
} 
Creemos que la denominación "violencia escolar" evidencia dos dificultades: la primera alude a la vaguedad del término: ¿qué acciones violentas serían específicamente escolares? O dicho de otro modo ¿cómo es posible discernir entre una acción violenta "escolar" y una acción violenta "a secas"? A simple vista pareciera que la cuestión se reduce a lo espacial sin aportar nada significativo a la problemática. La segunda dificultad se centra en la estigmatización y el señalamiento que recibe una escuela -y sus integrantescuando es incluida dentro de esta caracterización. De acuerdo con Kaplan, "la violencia adjetivada como escolar es, a nuestro entender, una noción ambigua y, como tal, puede cumplir funciones sociales de instalación de ciertos discursos criminalizantes e individualizantes" (2015: 21). En este sentido, dos integrantes del Equipo de Orientación Escolar expusieron:

Cuando vos empezás a indagar un poquitito más allá del hecho puntual que el profesor declara, te das cuenta que también hay una violencia de parte del profe. Esa es la violencia que generalmente está instalada. Esto está instalado en las instituciones educativas, donde se naturaliza y muchas veces se pone el punto o la mirada en el alumno (Marianela, "escuela de la periferia norte").

Si hay un adulto y hay un alumno, generalmente el violento termina siendo el alumno y el adulto queda como por fuera de la situación (Gabriela, "escuela de la periferia norte").

La denominación "violencia escolar", que pareciera remitir a una enfermedad fácilmente detectable, promueve el establecimiento cierta percepción negativa alrededor de la escuela que, lejos de promover la búsqueda de respuestas, profundiza los problemas asociados a la violencia y los instala aún más al interior de la institución. Esta naturalización de preconceptos afecta particularmente a los alumnos, quienes suelen ser catalogados como seres "violentos" y hasta "criminales". Radicalizando esta interpretación, pareciera que el riesgo ya no se encontraría fuera de los muros de la escuela, sino dentro de esta.

Es a partir de este breve recorrido teórico que, aun con ciertos recaudos en torno a la reproducción de prejuicios y tipificaciones, preferimos utilizar el término "violencia en las escuelas"; fundamentalmente por tratarse de un fenómeno que, si bien puede analizarse en el contexto escolar, tiene causas y manifestaciones que no se reducen exclusivamente a un espacio físico institucional. Al respecto, la integrante del E.O.E. de la escuela de periferia norte, ya citada, expresa: "la realidad es que la violencia está instalada en la escuela pero es una violencia social que por supuesto traspasa las paredes de la escuela". 


\subsection{El desnivel en los parámetros de percepción}

Junto al problema de los alcances, se halla el de la tolerancia. Las percepciones, los límites y las sensibilidades asociadas a la violencia varían de una cultura a otra y de un momento histórico a otro. En este sentido, y fundamentando sus análisis en la expansión de los deportes en Inglaterra (entre los siglos XVIII y XX), Norbert Elias y Eric Dunning afirman que las reglas y las relaciones de interdependencia que dan forma a al juego y el deporte también constituyen parámetros a partir de los cuales es posible medir el desarrollo de una civilización. De esta manera, los juegos medievales como el knappan, ${ }^{30}$ caracterizados por una lucha de todos contra todos (y donde la violencia física formaba parte de la propia práctica) comienzan a mutar hacia actividades más regladas y con menos contacto "cuerpo a cuerpo". Estos cambios se entrelazan con otros más generales acontecidos en la sociedad inglesa posrevolucionaria, que fueron desacreditando el uso de la violencia en la mayoría de las actividades sociales. En este sentido, Dunning sostiene que estamos en presencia de un declive en el anhelo de atacar y que "esto ha llevado consigo, primero, un descenso en el umbral de rechazo al derramamiento de sangre y otras manifestaciones directas de la violencia física" (1992: 275). En el quinto capítulo se tratará este tema con mayor profundidad.

En el ámbito escolar, hoy nos encontramos frente a una gran variedad de interpretaciones, las cuales, lejos de evidenciar consensos, ponen de relieve la permanencia de distintos parámetros de tolerancia. Esta situación conduce a una serie de interrogantes: ¿qué gravedad o qué tipo de consecuencias ameritan que un hecho sea incluido bajo el rótulo de "violento"? ¿Bajo qué indicador es posible medir este tipo de actos? Y por último, ¿cuál es el umbral de tolerancia de la violencia en contextos específicamente escolares?

Las acciones que usualmente son identificadas por las generaciones mayores como

\footnotetext{
${ }^{30}$ El knappan es un juego popular de la Edad Media sin límite de jugadores ni espacio y con reglas orales, en el que se desarrolla una lucha generalizada de todos contra todos. Con un marcado contenido de lo que Dunning (1992) denomina violencia afectiva, los pobladores solían utilizar el evento como una purga para descargar físicamente los resentimientos acumulados hacia familiares, vecinos, etc. La mención de esta práctica no es azarosa, su directa vinculación con la Edad Media sirve de respaldo a los estudios de Elias y Dunning sobre del avance de la civilización y la limitación de acciones violentas en las actividades recreativas. Poco a poco, el knappan introdujo restricciones sobre la violencia física y sus reglas fueron explicitadas de manera escrita, dando paso a lo que hoy conocemos como rugby.
} 
violentas, no son percibidas de igual modo por los jóvenes. Mientras que para un adulto el simple contacto físico puede significar un acto violento, para los más jóvenes puede tratarse de un juego, un modo de comunicación o incluso una demostración de afecto. Duschatzky y Corea se toparon con este problema cuando trataron de analizar las recurrentes manifestaciones de violencia protagonizada por un grupo de jóvenes de la ciudad de Córdoba. En sus propios términos:

En la escuela, la violencia no es vivida por sus protagonistas como un acto de agresividad, sino como un modo de trato habitual y cotidiano. La violencia en la escuela es identificada como tal por un observador y no por sus agentes. Son los docentes, en la posición de observadores, quienes hablan de violencia cuando constatan que los comportamientos habituales de los alumnos son la negación de la representación que corresponde a la condición de alumno (2013: 26).

Por su parte, durante la proyección de un video empleado como recurso disparador para una entrevista grupal, dos alumnas (pertenecientes a la "escuela del barrio ferroviario") expusieron: "no se están pegando, se están agarrando de los brazos". "En realidad no se pelearon, se agarraron los pelos nada más. Una pelea es cuando se dan en la jeta y se abren la cabeza, algo así”. Nos encontramos aquí frente a un parámetro cambiante en lo que refiere a la identificación de un acto violento. Dicho de otro modo, pareciera que la distancia intergeneracional entre docentes y alumnos promueve la coexistencia de distintos grados de tolerancia. Para muchos jóvenes "la violencia no es percibida como tal, en tanto no hay registro de un límite violado" (Duschatzky y Corea, ibíd.: 25). Ahora bien, el problema de este desacuerdo se agrava aún más cuando los adultos se corren de lo que las autoras denominan la posición de observadores. En otras palabras, el problema se recrudece significativamente cuando los docentes y autoridades no son capaces de advertir el estallido de episodios violentos, o lo que es aún peor, advierten el conflicto pero no hacen nada al respecto. Es el caso de una vice-directora, que en el contexto de una charla informal, reconocía que "cuando se empiezan a pegar en la escuela, los saco afuera y que se maten ahí”.

Cuando un conflicto considerado violento no es mediado por la intervención de un adulto, el mismo corre riesgo de naturalizarse como un modo de relación en que el que se desconoce tanto la posición del otro, como la de una autoridad capaz de apaciguar y resolver las diferencias. En un escenario donde la función histórica del adulto como autoridad pareciera resquebrajarse, los parámetros de tolerancia descansan en manos de los 
jóvenes, quienes, atendiendo a sus códigos, pueden elevar el umbral hasta desencadenar situaciones riesgosas tanto para ellos mismos como para quienes los rodean.

A primera vista pareciera que el problema de los alcances y la tolerancia trascienden el objeto de estudio planteado; sin embargo no podemos pasar por alto su mención, puesto que las confusiones asociadas al término colaboran con la permanencia de límites confusos y peligrosas arbitrariedades. Aquí resulta pertinente atender Kessler, quien, a partir de un relevamiento en escuelas catalogadas como violentas, advierte:

Directivos y docentes admitían que reinaba un clima de conflicto escolar, pero también la dificultad de llegar a un consenso con los alumnos sobre qué es la violencia. Muchas veces, lo que para los chicos era considerado un juego para los docentes era considerado violencia. Entonces ahí hay una cuestión central: ¿cómo ponerse de acuerdo? Uno no tiene por qué aceptar -pienso yo- lo que el otro dice que no es violencia, pero hay una primera cuestión a definir que es un consenso sobre qué es violencia (2006: 17).

Por lo hasta aquí desarrollado, asumimos que no es posible construir una definición certera del fenómeno comúnmente denominado violencia en las escuelas. ${ }^{31}$ Pese a esto -y para no caer en las mismas vaguedades que pretenden evidenciarse-, consideramos preciso aclarar, al menos de un modo aproximado, a qué nos estamos refiriendo cuando empleamos este concepto.

En línea con la hipótesis que guía la presente investigación, entendemos que la violencia en las escuelas hace referencia a aquellas manifestaciones exteriorizadas generalmente de manera física, en las que un sujeto vinculado en algún punto con los roles escolares pretende, por causas generalmente asociadas a la reconfiguración de la autoridad y el debilitamiento del lenguaje, ocasionar un daño evidente en el otro o en sí mismo. Si bien esta caracterización se aplica en mayor medida a los estallidos de violencia protagonizados por los jóvenes, los adultos también se manifiestan de manera violenta -aunque en este sector la violencia suele emplearse como un intento desesperado por restablecer la autoridad. Claro que esta es una conceptualización abreviada que deja fuera una gran cantidad de variables; solo se trata de un recorte posible del término, ordenador de la presente tesis.

\footnotetext{
${ }^{31}$ En línea con Noel (2006), consideramos que la violencia no es un objeto fácilmente objetivable, sino que, por el contrario, es un modo de catalogar ciertos comportamientos que, de acuerdo a las creencias y parámetros de valoración de un observador, pueden ser interpretados bajo ese rótulo. En palabras del autor mencionado: "la violencia, no es un observable -como sí lo es un empujón o una herida de bala- sino una forma de denominar o clasificar lo que uno observa. [...] Existe una zona gris bastante amplia para la cual las atribuciones de violencia varían: esto es, una clase de hechos que algunos actores calificarán de violentos y otros no" (39-40).
} 


\subsection{La multiplicidad de manifestaciones}

Lejos de acotarse al ámbito de lo escolar, la temática no reconoce límites entre el interior y el exterior de la institución educativa. Para la mayoría de los autores especializados en la problemática, la violencia que estalla en la escuela es una manifestación singular, ceñida únicamente al espacio institucional, sino el reflejo de cierta violencia acontecida -y últimamente recrudecida- a escala social. Según Osorio: "la violencia institucional es expresión de la violencia social; podría decirse que es una de sus formas” (2006: 119).

Si bien esta investigación está enfocada en el ámbito educativo escolar, no podemos obviar la influencia -sobre todo en la percepción de la gravedad del fenómeno- de ciertas manifestaciones populares comúnmente ligadas a la violencia, las cuales suelen condensarse en la categoría: "violencia social". Dentro de este agrupamiento -utilizado recurrentemente en los medios masivos de comunicación- se destacan la violencia en el fútbol, la violencia policial, la violencia de género, la violencia en el tránsito y la violencia delictiva, entre otros. Desde un punto de vista "pesimista" o "fatalista", los hechos frecuentemente incluidos dentro de estas categorías pueden interpretarse como "pequeñas expresiones" de un problema de violencia a gran escala. Sin embargo, debido al amarillismo con que suelen ser tratados en muchos medios de comunicación, estos hechos deben ser analizados con cierta cautela. El problema de la "violencia social", aunque a primera vista pareciera revelarse "evidente" o fácilmente identificable, se trata de un asunto muy difícil de categorizar para su análisis científico. Dicho de otro modo, los mismos discursos que dan forma al objeto: "la violencia en...", también lo vuelven susceptible a la reproducción de prejuicios y malos entendidos. Como dijimos anteriormente, no es un dato menor el hecho de que la mayoría de las investigaciones referidas a la violencia generalmente se nutran de testimonios brindados desde la posición de víctima. Siguiendo esta línea, consideramos oportuno atender la opinión de una de las autoridades entrevistadas:

La violencia se genera del afuera hacia el interior de la escuela. [...] En la escuela se están vivenciando cosas que pasan en el barrio o afuera, como por ejemplo, los robos. Siempre falta un celular o dinero de un bolso y eso no lo generamos nosotros. [...] Ellos vienen con esa carga negativa a la escuela, por ejemplo, el tema de la droga... es un problema terrible en estos momentos. Yo lo veo a la mañana cuando se juntan en la otra esquina a fumar antes del ingreso y eso genera otros conflictos (vicedirectora, "escuela del centro"). 
En este contexto, no sería coherente hablar de una violencia aislada al interior de un colegio; por el contrario, pareciera que el fenómeno se enmarca dentro un problema aún mayor, que, en cierta forma, involucra a la sociedad argentina contemporánea. La conferencia de Silvia Bleichmar, publicada bajo el título Violencia social - violencia escolar, se adentra de lleno en esta cuestión. En términos de la autora:

Antes era inexplicable que, en un país como el nuestro, ocurriera algo como lo que pasó en Carmen de Patagones; o que un chico intentara golpear a su maestra [...]; o que una madre intentara golpear a un docente. Era imposible que alguien llevara un destornillador para agredir a un compañero (2008: 26).

Hoy no se trata de algunos conflictos esporádicos y poco relevantes; el problema en cambio se centra en la magnitud y la diversidad de los actores involucrados. Los modos en que se desarrollan algunos eventos catalogados como "violentos" en ocasiones parecieran exceder los mecanismos de contención que prevé el sistema educativo formal. Al respecto, Bleichmar sostiene: "yo no concuerdo con los que plantean que estas nuevas formas son las formas actuales de un fenómeno que ocurrió siempre" (ibíd.).

En muchas de las entrevistas realizadas, esta diversidad y multidireccionalidad del fenómeno es un tema recurrente:

Uno ve violencia en cuanto a los chicos y en cuanto a docentes que son violentos con los chicos; también chicos que son violentos entre ellos y docentes que son violentos entre ellos... y también chicos que son violentos con docentes. Y padres que son violentos con quien pueden [...]. Una madre quiso ingresar "de prepo" a la escuela y yo la frené porque estaban los de primaria y tenía miedo que lastime a alguno. Me paré enfrente y le pedí por favor que se tranquilice, que cuando se tranquilizara yo la iba a dejar pasar. La acompañé hasta la puerta y cuando estaba a punto de salir me pateó la reja a propósito para golpearme; además me pegó en el pecho con algo de metal y me dejó una marca. [...] Lo feo es que los chicos se enganchan con eso, no toman consciencia de que es el trabajo de uno y que uno tiene que mantener una familia y no estás de joda ahí. La madre alteró los ánimos de un grupo de chicos que tenían muy buena conducta y empezó a generar una cadena que ya no la paraba nadie (preceptor, "escuela del barrio ferroviario").

A mí me parece que algo que no estamos diciendo es que la violencia se ejerce hacia los jóvenes. Estamos hablando como si los jóvenes fuesen los únicos que tienen manifestaciones de violencia y la verdad que las instituciones en su formato, y los adultos en particular, provocan y realmente tienen actitudes violentas hacia los jóvenes (integrante de un Equipo Distrital de Infancia y Adolescencia).

Dos chicas se mandaban mensajes de texto por el celular, "que te voy a cagar a palos y esas cosas", entonces vino la mamá de una furiosa a buscar a su hija porque esta otra le iba a pegar. Entonces viene la madre de la otra y se armó un quilombo en preceptoría terrible. Una gritaba y la otra gritaba, estaban las cuatro, las dos hijas y las dos madres (preceptora, "escuela de la periferia norte").

Cuando intentamos desglosar el fenómeno e indagar las direcciones en que se 
suelen llevar a cabo las manifestaciones consideradas violentas por los agentes educativos (adultos), podemos observar que hoy no se trata únicamente del exceso de autoridad de un profesor (como se relata en el primer extracto citado). Muchos docentes prefieren no involucrarse en los conflictos que acontecen en la escuela, sino refugiarse en la inactividad y la indiferencia. Tampoco se trata de la rebeldía de un alumno o un grupo de alumnos que se pronuncian en contra "del sistema"; ni de un complot generacional que pretende socavar intencional y sistemáticamente las funciones de los educadores; no se trata de un medio para ejecutar ideales "revolucionarios", ni para intentar modificar el status quo. De acuerdo a los testimonios recolectados, la violencia que manifiestan los jóvenes no suele estar dirigida hacia la exteriorización de un reclamo o una protesta; esta no parte del grupo hacia afuera, sino que, por el contrario, mayormente se recluye al interior del propio grupo.

En este sentido, los hechos que los alumnos entrevistados identificaron como "violentos" no revelaron vinculación alguna con la exteriorización consensuada de una demanda o con el sostenimiento de una ideología política (como quizás sí ocurría con los jóvenes de los '60 o los '70). En otra vertiente, los relatos vinculados con la violencia se concentraron dentro del mismo sector etario. Interpretando el testimonio de los jóvenes consultados, la violencia pareciera constituir un recurso sencillo y eficaz comúnmente empleado para la defensa, la resolución de conflictos, el establecimiento de jerarquías, la demanda de respeto, etcétera. En esta línea consideramos pertinente atender nuevamente a las reflexiones de Bleichmar:

Mi mayor preocupación con respecto a la violencia no está en la violencia en sí misma, porque es parte de la vida y parte de la historia. El problema es qué tipo de violencia [...]. Sin ella no se podría haber hecho la Revolución de Mayo. [...] La cuestión es esa, qué sentido tiene el ejercicio de la violencia. El ejercicio de la violencia individual, y como explosión, es puramente destructivo (2008: 60).

Muy difícilmente podamos encontrar alguna una ideología o intencionalidad manifiesta detrás de "hacerse el gato", "mirarse mal” o "abrirse la jeta": aquí se trasciende la discusión respecto de los medios y los fines, porque pareciera que la violencia ha llegado a convertirse en un fin. Según Duschatzky y Corea (2013), en algunos contextos la violencia no parece ser la excepción, la trasgresión de una regla, sino un modo de vivir la cotidianeidad. En el contexto en el que las autoras desarrollan su investigación (un barrio en la periferia de la ciudad de Córdoba a finales del siglo pasado), el empleo de la violencia no sería algo ocasional -y penado- sino un recurso habitual que, en cierta forma, vendría a 
ocupar el lugar del lenguaje.

Siguiendo esta línea, podría decirse que en determinados contextos históricopolíticos, el cuerpo -reducido a una materia viva que reacciona automáticamente ante un estímulo- parece ocupar el lugar de los símbolos. El resultado es la acción de un cuerpo mudo, o, en términos arendtianos, un cuerpo escindido del lenguaje (Arendt, 2014): una "cosa física" empleada como instrumento para la dominación, la experimentación del límite y la supervivencia. Este tema será retomado en el tercer capítulo.

Sintetizando: lejos de tratarse de un cruce de palabras entre docentes y alumnos, el asunto que, con fines analíticos, identificamos como "violencia en las escuelas", parece desprenderse de un problema social de mayor escala, comúnmente denominado -por la bibliografía especializada- "violencia social". Esta conexión entre "lo social” y "lo escolar" se hace evidente, por ejemplo, en los testimonios de algunos adultos entrevistados, quienes, a la hora de identificar situaciones "violentas", advirtieron sobre la participación de actores históricamente "excluidos" del ámbito escolar. Tomando como referencia el relato del preceptor citado más arriba, pareciera que la intrusión ocasional de actores "externos" (familiares, amigos, vendedores de droga, miembros de bandas barriales, etcétera) puede considerarse, eventualmente, como un factor agravante del fenómeno. Si bien esta clase de "intrusiones" ocurren con escasa frecuencia -de los once adultos entrevistados, solo uno de ellos hizo referencia específica a un acontecimiento de estas características-, no podemos dejar de mencionar la existencia de algunas dificultades a la hora determinar la jurisprudencia que tiene la escuela, particularmente en relación al manejo de situaciones conflictivas en las que participan actores "ajenos" a la institución.

\subsection{El marco sociopolítico}

A partir de la Ley 26.206 de Educación Nacional sancionada en el año 2006, muchos autores e informantes adultos hablan de una "escuela nueva" o "nueva ley de educación". Esta ley, al extender la obligatoriedad del nivel secundario e incluir a sectores históricamente exceptuados, también habría traído aparejada una serie de problemas vinculados a esta nueva función inclusiva. ${ }^{32}$ El testimonio de una psicopedagoga resume

\footnotetext{
${ }^{32}$ Sobre la extensión de la obligatoriedad del nivel secundario y las dificultades asociadas a esta medida, es relevante atender la opinión de Southwell, quien sostiene que "las políticas desarrolladas entre 2006 y 2015 , fueron un puntapié muy significativo al incorporar el nivel secundario completo a la obligatoriedad de la
} 
algunas de estas cuestiones:

Esa sensación de que ahora [la violencia] aparece más en la escuela secundaria, debe tener que ver con que no estaban todos en la escuela secundaria hace un tiempo, y ahora hay muchas más posibilidades de situarse desde el vínculo con un montón de sujetos que son diferentes. Si se anotaban en la escuela, a la primera situación que aparecía, la escuela tenía reglas de expulsión libres. Podían no ir a la escuela, como no era obligatorio y era de elite, aquellos que no estaban dentro de los parámetros que la escuela esperaba rápidamente se lo excluía y no seguía estudiando (miembro de un Equipo Distrital de Infancia y Adolescencia). ${ }^{33}$

El análisis de este relato nos obliga a introducir algunos cuestionamientos sobre la función de la escuela, la familia y los roles históricamente asignados a cada institución en los últimos tiempos. La crisis del año 2001 puso la satisfacción de las necesidades básicas en la cima de todas las agendas, incluidas la educativa; el auxilio de las carencias se convirtió en una urgencia ineludible. Por entonces, los debates al interior de escuela pública se centraban en la imposibilidad de enseñar frente a chicos desnutridos que se desmayaban durante las clases. "Con hambre no se puede aprender", fue el lema que incentivó la creación y ampliación de comedores en un gran número de instituciones educativas públicas.

En numerosas escuelas hubo que mantener los comedores abiertos durante las vacaciones porque si no, los niños no comían [...]. Indudablemente, en los últimos tiempos, la escuela ha abierto un enorme debate, sobre todo en los años 2001-2002: si la función de la escuela es alimentar o educar. Esta discusión explicita una tensión permanente, muy grave, entre necesidades actuales y necesidades futuras (Bleichmar, 2008: 33).

Este llamado desesperado a la intervención del estado -contextualizado en un momento de creciente polarización y desigualdad- se debió a la imposibilidad de grandes porciones de la población por solventar necesidades de primer orden (fundamentalmente alimentación, vestimenta y techo). Ahora bien, esta tarea asistencial comprometió la continuidad en la función educadora de la escuela; el ingreso de nuevas e ineludibles responsabilidades desplazó la transmisión de saberes como principal eje ordenador. Con esta reconfiguración de la escuela -en la que, siguiendo a Arendt (2014), se hace evidente el entrelazamiento entre actividades históricamente consideradas privadas y actividades propias del espacio público-, la satisfacción de necesidades vitales fue ganando cada vez

enseñanza. Asimismo, instalaron fuertemente la noción de la inclusión como condición necesaria para una educación democratizadora" (2018: 1). Profundizando la perspectiva de la autora, estos esfuerzos por hacer más inclusiva la escuela secundaria requirieron, en muchos casos, una desarticulación -y una consecuente reconfiguración- de la rigidez del formato institucional tradicional, o en términos de Bracchi, la posibilidad de pensar que "no hay una única manera de ir a la escuela" (Bracchi, en: Southwell, 2018: 3).

${ }^{33}$ El texto entre corchetes es propio. 
más terreno.

Esta nueva función de la escuela pública -estrechamente ligada a la urgencia de la época- significó un cambio trascendental en su representación social; de una percepción ligada al ascenso socio-económico y a la preservación de una cultura, gradualmente comenzó a ganar terreno otra en la que la mantención de la vida biológica, o la vida zoé en términos de Esposito (2006), fue la prioridad reguladora. A riesgo de generalizar, puede afirmarse que el problema de esta nueva ocupación de la escuela es que no se estructuró en base a un proyecto integral capaz de asegurar la transmisión de saberes. Siguiendo esta línea, Bleichmar advierte que "una enorme cantidad de niños son asistidos en todo sentido por la escuela, de tal forma que el aprendizaje pasa a ocupar un lugar secundario [...]. Esto pone en evidencia una situación terrible en el país" (2008: 33).

Al convertir las necesidades básicas en el principal eje ordenador, la escuela se sumó a un proceso de debilitamiento institucional generalizado -iniciado en la dictadura y acelerado en los noventa-, por el que la institución educativa fue perdiendo relevancia simbólica en nuestra sociedad. A la escuela se asiste a recibir cuidados y educación en relación directamente proporcional respecto al grado de vulnerabilidad de la zona en que se enmarque cada institución. De esta manera, el volumen de contenidos que se imparten en un colegio queda supeditado a la atención de las urgencias que la población requiera. Desde los albores del siglo XXI, problemas como el hambre, el desempleo y la asistencia social comienzan a resolverse en el marco de la institución escolar.

Podría pensarse la función asistencial de la escuela siguiendo la tesis de Arendt (2014), por la que los estados modernos se inmiscuyen cada vez más en la esfera privada intentando regular todos los aspectos de la vida. Siendo algo exagerados, podría decirse que la escuela pasó de ser el lugar donde se educa, al lugar donde se vive. El colegio funciona como un apéndice del hogar y, como en la mayoría de los hogares, es allí donde deben resolverse conflictos de diversa naturaleza. Siguiendo a Arendt, esto constituye una incompatibilidad, puesto que "el objetivo de la escuela ha de ser enseñar a los niños cómo es el mundo y no instruirlos en el arte de vivir" (1996: 207).

Para las familias que dependen exclusivamente del estado, la asistencia de los hijos 
a la escuela se convierte en una necesidad vital. ${ }^{34}$ Sin la acreditación de esta asistencia obligatoria, las familias corren el riesgo de perder el acceso a los servicios prestados. Tal como afirma la directora de la "escuela del barrio ferroviario":

Ahora existe la asignación universal por hijo y la obligatoriedad de asistencia a los centros de salud... todo eso con el condimento de la asistencia obligatoria a la escuela. [...] Se nota muchísimo la discriminación de los adultos, de los docentes, y los chicos entre sí también. Hay que entender por qué una persona necesita un plan. Tener un plan no es algo alegre sino que es algo necesario, es casi vital. Porque sin ese plan no tendrían nada.

En un contexto de crisis institucional, la premura del asistencialismo y la satisfacción de necesidades básicas parecieran haberse impuesto a costa de la transmisión de saberes, el reconocimiento de la autoridad y el valor pacificador del lenguaje, elementos necesarios para llevar adelante cualquier tarea educativa. Las últimas reformas incluidas en Ley de Educación Nacional $N^{\circ} 26.206$ promovieron la expansión de una escuela que, si bien atiende necesidades urgentes, también se revela atravesada por serios problemas de conflictividad.

Retomando los aportes de Arendt (2014), el espacio privado podría caracterizarse como el lugar donde se establecen las diferencias entre los miembros de la familia, se conforman los primeros lazos sociales y se resuelven los conflictos. En pocas palabras, es el primer lugar donde se aprende a vivir y a relacionarse con otros. La transposición de estas funciones hacia la escuela pareciera haber desencadenado un proceso de confusión generalizada en lo que refiere a las responsabilidades de los adultos. En este sentido es pertinente el relato de algunos adultos entrevistados:

Los chicos vienen con muchas problemáticas. Vienen a contar todo lo que les pasa en sus casas. Hay mucha depresión, hay mucho problema en los chicos de tristeza y angustia que no tienen donde manifestarlo [...]. Los chicos no se animan a decirlo enfrente de todos, pero sí cuando nosotros vamos viendo, los acercamos al gabinete y trabajamos muchísimo (vicedirectora, "escuela del centro").

Algunas familias tienen problemas. Entonces muchas veces los chicos terminan expresándolo en el ámbito escolar. Y no es porque el compañero le dijo algo o le tiró una

\footnotetext{
${ }^{34}$ Desde otra perspectiva, la percepción de un subsidio (destinado a una familia o una persona singular) suele ser uno de los principales motivos de señalamiento o discriminación en contextos escolares; esto sucede a causa de la connotación negativa que envuelve la condición de "vulnerabilidad" en nuestra sociedad (Nuñez, 2015). A pesar del discurso reivindicatorio (en términos de derechos humanos) que se pretende establecer por medio este tipo de acciones políticas, las etiquetas que remiten a una situación de "pobreza" o "precariedad" suelen arrastrar una serie de preconceptos y estigmatizaciones. Siguiendo la línea del autor mencionado, la persistencia de estos prejuicios revela, al menos, dos dificultades: por un lado, se agrupa bajo un mismo paraguas a personas que pueden atravesar experiencias diferentes, y por otro, al caracterizar a determinada población como "vulnerable" se establece una representación o un encasillamiento que parte de un faltante o una limitación, por lo general asociado a la escasez de recursos económicos.
} 
tiza. Sino porque ese chico, probablemente, está afectado por alguna cuestión que está pasando en la casa. Que puede ser una separación o puede ser violencia intra-familiar también (vicedirectora, "escuela de la periferia norte").

Hay papás y mamás que dicen "no me molestes, yo no tengo tiempo de ir a la escuela, que la escuela se ocupe de mi hijo o de mi hija en el tiempo que le corresponde porque yo no voy a ir". Ellos se desentienden, pero eso marca un grado de violencia muy fuerte en las familias de esos chicos y bueno... obviamente eso se mete adentro de la escuela. Los adolescentes traen problemáticas desde las familias (directora, "escuela del barrio ferroviario").

La nueva función de la escuela creó espacios grises, o vacíos de autoridad, en los que se dificulta reconocer adultos responsables (tanto padres como docentes). Estos vacíos se evidencian a la hora de resolver situaciones de violencia: las autoridades escolares demandan una mayor presencia de los padres y estos, a su vez, acusan a la escuela de no garantizar la seguridad que ellos desean para el cuidado de sus hijos. Mientras tanto, los jóvenes ocupan un lugar de peligrosa hegemonía, puesto que el contexto socio-político alienta un movimiento iniciado algunas décadas atrás por el que la figura del joven se impone como ideal, borrando las distancias intergeneracionales entre los diversos sectores etarios. Para Corea y Lewkowicz,

Debido a las mutaciones culturales, la producción institucional de la infancia en los términos tradicionales es hoy prácticamente imposible. [...] Como cualquier institución social, la infancia también puede alterarse, e incluso desaparecer. La variación [...] está asociada a las alteraciones que, a su vez, sufrieron las dos instituciones burguesas que fueron las piezas claves de la modernidad: la escuela y la familia (1999: 3).

Sumado a los efectos devastadores de la crisis socio-política que caracterizó a la argentina de comienzos del siglo XXI, los discursos pedagógicos de la época se preocuparon por adherir a una tendencia generalizada en occidente, por la cual los niños y jóvenes comienzan a gozar de cada vez de más privilegios, llegando a ocupar un lugar que podría considerarse hegemónico. Decisiones familiares, objetos de consumo (como alimentos, tecnología, indumentaria, música), programas de televisión, viajes, etcétera: todo pasa en algún punto por el deseo de los jóvenes. Bajo la bandera de la "autonomía" se promovió la creación de una sociedad específicamente infantil; artificio inestable y, sobre todo, riesgoso para los propios jóvenes. Sin recursos simbólicos, estos deben arreglárselas en un mundo cada vez más hostil, competitivo e individualista. En Frankestein Educador, Meirieu advierte que esta exacerbación contemporánea del narcisismo infantil no representa el desarrollo de la autonomía sino que, por el contrario, la constante e ilimitada satisfacción de los deseos genera un estado de dependencia y achatamiento de la vida cualificada: 
Ya sabemos que el niño llega al mundo infinitamente pobre, y que no puede desarrollarse más que gracias a un entorno estimulante y a su inscripción en una cultura. Atender sus peticiones, someterse a sus necesidades, proponerle tan sólo aquello que tiene ganas de hacer y que ya es capaz de hacer, es arriesgarse a mantenerlo en un estado de dependencia, incluso en una vida vegetativa en la que, privado de exigencias, se dejará caer al nivel más bajo [...]. No hay que subordinar toda la actividad educativa a los caprichos de un niñorey. La educación, en realidad, ha de centrarse en la relación entre el sujeto y el mundo (2003: 68-70).

Recapitulando: si bien los procesos históricos no pueden ser reducidos a una fecha en particular, muchas de las causas del actual fenómeno denominado violencia en las escuelas pueden rastrearse en las postrimerías de la crisis socio-política que atravesó el país durante la década de 1990 (hasta tener su momento más álgido en el año 2001). El caos político, la corrupción, la "violencia" social, las dificultades de las familias por asistir a sus hijos y el creciente protagonismo del joven como el modelo ideal en un mundo desregulado, fueron cimentando las bases de un problema que se perpetuaría hasta nuestros días. Los niños del 2001 fueron recorriendo estos caminos plagados de confusiones y vacíos de autoridad; los adultos estaban muy ocupados (intentando amortiguar los efectos residuales de la crisis) como para hacerse cargo de ellos. Sería una actitud muy hipócrita sorprenderse hoy por las formas en que las nuevas generaciones se relacionan con el mundo, ya que -exagerando un poco la expresión- pareciera que nadie se preocupó por asegurar su cuidado y su educación. Y es que, en términos arendtianos:

Como el niño no está familiarizado aún con el mundo, hay que introducirlo gradualmente en él; como es nuevo, hay que poner atención para que este ser nuevo llegue a fructificar en el mundo tal como el mundo es. [...] Ante el niño, el maestro es una especie de representante de todos los adultos, que le muestra los detalles y le dice: «Éste es nuestro mundo» (Arendt, 1996: 201).

\subsection{Debates sobre el recrudecimiento de la problemática}

Si bien la discusión sobre los alcances y la tolerancia revela una coexistencia de interpretaciones sumamente variadas, resulta muy difícil hallar algún trabajo dedicado a esta temática en el que se refute o se desmienta por completo la existencia del fenómeno. La bibliografía especializada y, sobre todo, los medios masivos de comunicación hablan de la violencia en las escuelas como un problema que, en términos generales, evidencia una tendencia cada vez más grave y recurrente. Al no existir una base de datos con anterioridad al año 2005, fecha en que se creó el primer Observatorio Argentino de Violencia en las 
Escuelas, ${ }^{35}$ se vuelve muy difícil construir una hipótesis respecto de la evolución de la problemática atendiendo únicamente a la información proporcionada por organismos oficiales.

La ausencia de estudios a largo plazo se hace aún más evidente si se tiene en cuenta el tratamiento de los medios masivos de comunicación. Anteponiendo un marcado y peligroso sensacionalismo -coincidente con una creciente $\mathrm{y}$, por momentos, exacerbada preocupación por la seguridad ciudadana-, los medios parecen haber introducido -y naturalizado- cierta sensación de alarma en todo lo que refiere a la "violencia escolar". Este tendencioso tratamiento de la información, el cual podría considerarse como una falsa percepción de la realidad que acontece día a día al interior de las escuelas, favorece la producción y reproducción de numerosos preconceptos y arbitrariedades. Dicho de otro modo, si se quisiera establecer un parámetro de medición del fenómeno estudiado empleando únicamente los datos publicados en los medios masivos de comunicación, las escuelas podrían compararse con campos de batallas. Siguiendo a Zizek (2008) podría decirse que, en términos generales, muchos medios de comunicación no pretenden transmitir ningún tipo de mensaje o reflexión ligado a este tipo de información. En contraposición, el cubrimiento mediático de una pelea, una acción bélica o un atentado suele realizarse a través de un bombardeo de imágenes crudas que, lejos de incentivar el análisis y la reflexión, provocan una especie de "acostumbramiento" en el espectador.

Atendiendo al recorte geográfico previsto para la presente investigación, los medios de difusión de mayor alcance en la ciudad de La Plata también evidencian, en los últimos años, una creciente visibilización de la temática en cuestión. Al respecto, algunos titulares del diario con mayor alcance en la región expresan:

Alarma por otro caso de violencia en la escuela (Diario El Día, ejemplar del 26 de abril de 2012)

Alumna apuñalada. Salvajismo en la puerta de una escuela (Diario El Día, ejemplar del 31 de agosto de 2012)

Toda la sociedad, desafiada por el flagelo de la violencia en las escuelas (Diario El Día, ejemplar del 2 de Mayo de 2014)

\footnotetext{
${ }^{35}$ El observatorio dispone de una serie de trabajos comúnmente denominados cualitativos y cuantitativos, dirigidos fundamentalmente a la recolección de información y a la publicación de actividades y estrategias para trabajar cuestiones asociadas a la convivencia. El material consta de dieciséis volúmenes al momento de la confección de la presente tesis y se encuentra disponible en su sitio web: http://www.me.gov.ar/construccion/observa_biblioteca.html
} 
Los maestros se sienten "superados" por la violencia en las escuelas (Diario El Día, ejemplar del 6 de julio de 2014)

Las noticias asociadas a la violencia en las escuelas suelen confundirse con problemas en apariencia cercanos, entrelazando las causas de problemas de distinta naturaleza. Por lo tanto, es común advertir expresiones entremezcladas tales como: agresividad, agresión, bullying, ciber-bullying, grooming, acoso escolar, etcétera, términos empleados indistintamente para dar cuenta de una realidad signada por la conflictividad y el caos. Parafraseando a Kaplan (2015), los medios gráficos y audiovisuales llevan a cabo una espectacularización de la violencia que atraviesa la vida escolar, construyendo imágenes propias sobre los hechos ocurridos en ese ámbito. ${ }^{36}$

La gran mayoría de las noticias confluye en la denuncia respecto de la existencia de una peligrosidad creciente en los comportamientos de los jóvenes. Reafirmando lo dicho anteriormente, si nos dejásemos llevar por el contenido literal de los medios masivos de comunicación parecería que la cotidianeidad en las escuelas se viviera como un escenario de conflicto permanente. En este sentido, es común advertir el empleo de términos como: agresores, bandas, víctimas, ataque, defensa, muertos, heridos, internados, entre otros. Este tipo de términos, alejados de cualquier neutralidad, suele emplearse para describir hechos que en ocasiones exceden los límites legales y jurisdiccionales de las escuelas. Este tratamiento de la información alimenta dos creencias: que el fenómeno comúnmente denominado "violencia escolar" remite a un mal que se propaga por todo lo referido a "lo escolar" y que son los alumnos del nivel secundario quienes conforman el sector más proclive a cometer actos asociados con la violencia.

La crudeza de los medios en la cobertura de los casos rotulados como "violentos" se reitera en la mayoría de las entrevistas realizadas a jóvenes y adultos. En esta línea, se destacan los relatos de una integrante del Equipo Distrital de Infancia y Adolescencia (con funciones en la "escuela de la periferia norte") y un profesor de Construcción de la

\footnotetext{
${ }^{36}$ La construcción del problema comúnmente denominado violencia en las escuelas es producto de las investigaciones recientes en el ámbito de las ciencias sociales (y de la influencia del paradigma de las políticas públicas); por lo tanto, no se puede hablar de un fenómeno estrictamente nuevo, sino que se trata de un proceso que se ha exacerbado en los últimos años. Esto quiere decir que la objetivación del problema como algo que irrumpe en la escuela de manera intempestiva -como si se tratase de un atentado o una invasiónconstituye una lectura propia de los medios de comunicación, una caracterización sesgada por un marcado sensacionalismo y un engrandecimiento de los hechos que acaban por descontextualizar el fenómeno, atribuyéndole caracteres propios y creando cierto estado de paranoia en la población no familiarizada con el ámbito escolar.
} 
Ciudadanía (correspondiente a la "escuela del centro"):

Los medios de comunicación construyen fuertemente en nosotros la sensación de que esto es mucho peor ahora de lo que era antes.

La exposición genera más violencia; reproducir las malas noticias, ese es el punto. Los hechos de violencia son jla noticia! Cuando en realidad deberían ser las buenas [...]. Las malas noticias son las que se venden y se comercializan.

Cuando se le preguntó a un grupo de alumnas (perteneciente a la "escuela del barrio ferroviario") si las peleas causadas por "hacerse la linda" ocurrían frecuentemente, una de ellas usó la cobertura de los medios como parámetro de referencia para dar cuenta de la recurrencia: "Sí pasa ¿no vio la tele? Ahí dicen: me pegaron por ser linda”. En el mismo diálogo, la alumna reitera la mención a los medios para comparar la gravedad de los hechos violentos que acontecen en su escuela con otras instituciones: "lo que pasa acá es algo muy chiquitito, porque yo veo en la tele lo que pasa en otros lugares y esto no es nada". Este tema será retomado con mayor profundidad en el cuarto capítulo.

Frente a este panorama de creciente visibilización y paranoia generalizada, resulta fundamental llevar a cabo una desarticulación y desnaturalización de los discursos que atraviesan la temática. A fin de comprender el fenómeno sin replicar tendencias alarmistas, resulta pertinente atender el recorrido que propone Bleichmar (2008), quien, si bien reconoce el crecimiento del problema de la violencia en los últimos años, no basa su análisis en una serie de casos aislados, sino que vincula y retrotrae la problemática a una serie de eventos socio-políticos que afectaron -y afectan- a la Argentina desde hace varias décadas. Como ya vimos, la autora identifica tres momentos en este recorrido: en primer lugar hace referencia al abuso de la autoridad militar durante la última dictadura. En este marco Bleichmar identifica el comienzo de una creciente desconfianza hacia las instituciones, basada fundamentalmente en los excesos en la violencia empleada por las fuerzas militares y policiales y en el consecuente rechazo de los crímenes contra los derechos humanos por parte de la población civil. En segundo término, la autora incluye la década de 1990 y la caracteriza como un momento signado por el vaciamiento y la impunidad, situación que afectaría determinantemente el valor de la palabra en nuestro territorio. Este proceso, guiado por recetas neoliberales, aceleraría considerablemente la crisis institucional y simbólica iniciada dos décadas atrás. En tercer orden, Bleichmar hace hincapié en la crisis del 2001 y en los años inmediatamente posteriores. A esta altura, las familias que envían a sus hijos a las escuelas públicas evidencian serias carencias 
materiales y simbólicas como consecuencia de los eventos que atravesaron el país en su historia reciente. Esto genera un vacío institucional y un consecuente proceso de desubjetivación que se complementa con dos males de época: la ausencia de futuro y la inmediatez.

Para Bleichmar, estos elementos constituyen las principales causas del fenómeno en cuestión. Lo que hoy conocemos como violencia en las escuelas se trata de un problema que, lejos de ser algo circunstancial y atribuible a una institución o a un individuo, es una consecuencia del devenir de la historia argentina reciente, más precisamente, de una serie convulsiones políticas y sus consecuencias sociales, las cuales afectaron determinantemente el sistema educativo público. En sus palabras: "las formas actuales dan cuenta de procesos muy severos de desubjetivación en el país, y de procesos muy profundos de impunidad y resentimiento acumulados" (2008: 26).

\subsection{Conclusiones parciales}

A lo largo de este capítulo se intentó llevar a cabo un primer acercamiento al problema de la violencia en las escuelas, centrando la atención en algunas investigaciones previas, en el contenido de los principales documentos oficiales referidos a la temática y en el testimonio de algunos informantes. A fin de sistematizar la información relevada, a continuación se enumerarán cuatro ejes o categorías a través de las cuales intentaremos volcar, resumidamente, las cuestiones abordadas.

En primer lugar, intentamos hacer un acercamiento general a la temática. En esta aproximación fue posible evidenciar la trascendencia de un problema que resuena no solo en el ámbito educativo, sino también en diversos canales de comunicación social: libros, documentos estatales, medios de difusión masiva, internet, reuniones docentes, conversaciones casuales, etcétera.

En segundo término se puso el acento en la denominación del fenómeno y en los problemas que surgen a raíz de la multiplicidad de interpretaciones. La polisemia que envuelve a la violencia opera, siguiendo a Kaplan (2015), como un obstáculo epistemológico. Esto significa que, al tratarse de una expresión habitual que evoca sucesos muy disímiles, se hace muy difícil sistematizar una definición que opere como denominador común. Aquí es posible identificar dos problemas: el primero se refiere a los 
alcances del término. Al no tratarse de un fenómeno fácilmente identificable, cualquier actor escolar puede ser señalado -y estigmatizado- como "violento". Esto afecta mayormente a los jóvenes, quienes deben recibir el peso negativo de una serie de discursos sociales fundados en preconceptos y arbitrariedades. El segundo problema a resaltar es la tolerancia. Siguiendo a Elias y Dunning (1992), los niveles de aceptación de la violencia cambian de una generación a otra, de una sociedad a otra, e incluso de una familia a otra. Trasladando este análisis al ámbito educativo, hoy podemos advertir la coexistencia de diversos parámetros de medición: lo que un joven puede interpretar como un juego, a los ojos de un adulto puede parecer una actividad desregulada y carente de límites (más cercano a la representación de un acto violento). Frente a estas dificultades interpretativas, y frente a la circulación de una gran variedad de definiciones, se intentó recortar el término "violencia en las escuelas" para establecer un punto de partida posible. Recapitulando, creemos que se trata de un fenómeno que, si bien puede analizarse en el contexto escolar, tiene causas y manifestaciones que no se reducen exclusivamente a un espacio físico institucional.

En tercer lugar se destacaron las múltiples direcciones que adoptan las manifestaciones violentas en contextos escolares. Lejos de tratarse de un problema que se acota al espacio específico de la escuela, la cuestión de la violencia se enmarca en un problema social de mayor envergadura que afecta a la Argentina contemporánea. Esto se evidencia en la multiplicidad de casos y en la diversidad de actores involucrados. Dentro de la categoría "violencia escolar", hoy es posible encontrar eventos en los que se describe a padres golpeando a docentes, alumnos peleándose con alumnos o a directivos atrincherados en su oficina por amenazas provenientes de "afuera de la escuela". A pesar de la amplia variedad de manifestaciones, es posible rastrear algunas continuidades; en los capítulos subsiguientes se intentará identificar aquellas asociadas a los componentes centrales de la hipótesis, es decir, a la reconfiguración de la autoridad y al debilitamiento del lenguaje.

Concluyendo, en cuarto lugar se puso el acento en la identificación de algunas causas histórico-políticas, las cuales revelarían -de acuerdo a la mayoría de los autores mencionados- la exacerbación del fenómeno en los últimos años. Como señalamos, muchas de las revueltas que afectaron a la Argentina en los últimos años repercutieron de manera directa en el sistema educativo público (Bleichmar, 2008). Desde las atrocidades 
perpetuadas en la última dictadura militar, pasando por una década de vaciamiento generalizado y un período crítico a comienzos del nuevo milenio, la violencia se revela como una consecuencia lógica de una profunda crisis institucional y una carencia simbólica que caracterizó -y caracteriza- a la Argentina de los últimos años. Aquí se hace preciso introducir una aclaración: los hechos que comúnmente se engloban bajo el fenómeno de la violencia en las escuelas no pueden explicarse mediante la exposición cruda de los casos más explícitos, tal como lo hacen los medios masivos de comunicación. Por el contrario, el problema nos obliga a indagar asuntos históricos y políticos que trascienden el sensacionalismo y la propaganda. 


\section{Capítulo 2: La reconfiguración de la autoridad}

El primer derecho que tiene el niño es a una asimetría protectora [...]. Los hijos no somos amigos de los padres y los padres no somos amigos de los hijos, sino padres. Esto no contradice la idea de que un padre pueda tener un buen diálogo con sus hijos, la refuerza.

Silvia Bleichmar (2008).

\subsection{La tensión intergeneracional}

Una de las aristas que guía este trabajo presupone que la autoridad que históricamente estuvo asociada al rol del adulto hoy se encuentra en un proceso de cambio, de reconfiguración, de reformulación; los esquemas tradicionales, en los que se asumía que un docente -por el solo hecho de desempeñar esa función- debía ser respetado y obedecido, hoy no cuentan con la vigencia y la pregnancia que tuvieron en otros tiempos.

Con una caracterización algo melancólica de la autoridad, y asumiendo que todo tiempo pasado fue mejor, hoy es frecuente oír a muchos docentes -en salas de profesores, en pasillos, en reuniones de perfeccionamiento, etcétera- expresar su disconformidad en relación al respeto y la obediencia que reciben de sus alumnos. De acuerdo con Greco: “a menudo escuchamos hoy que son ellos [los alumnos] quienes no quieren aprender, que nada les interesa, que buscan el facilismo de las nuevas tecnologías o la huída a través de la apatía, el consumo, la droga, etc.” (2007: 16). Este tipo de caracterizaciones suelen realizarse personificando una autoridad jerárquica e inamovible que -más orientada a sostener las formas que a transmitir saberes- hace que muchos docentes solo puedan reconocer insuficiencias en sus alumnos.

Desde la perspectiva de los alumnos, las reconfiguraciones en la autoridad se suelen evidenciar en el rechazo a la figura del maestro tradicional (alguien que reclama subordinación desde una posición superior en una escala jerárquica) y en los modos de resolver conflictos de diversa naturaleza. Centrando la atención en el segundo elemento, es destacable el hecho de que muchos alumnos hoy prefieren dirimir sus asuntos empleando sus propios recursos -generalmente en términos físicos, anteponiendo el cuerpo-, en lugar de recurrir a algún preceptor, docente o autoridad. El propio Meirieu (2007) advierte que, 
actualmente, muchos de los jóvenes que se rehúsan a la autoridad de los adultos prefieren someterse a la autoridad clánica, dura y violenta de los grupos en los que se encuentran.

En las escuelas seleccionadas, todos los grupos entrevistados expresaron que no suelen acudir a los adultos (padres, docentes, directivos, etcétera) para que estos resuelvan las discrepancias que puedan surgir entre ellos. En cambio, para reclamar justicia, manifestar un descontento o expresar un punto de vista diferente, los alumnos hicieron mención a acciones tales como "agarrase a piñas", "agarrarse a patadas" o "cagarse a trompadas", entre otras. Esta situación revela, de manera provisoria, no solo la desconsideración de los mayores como portavoces de una ley aplicable a la resolución de problemas, sino también la coexistencia de parámetros disímiles en la medición de conflictos y en la aplicación de sanciones. Pareciera que el grupo -incluso ordenado bajo una estructura clánica- tiene algo para ofrecer que no pueden ofrecer los adultos: "Les dan quizás la idea de que van a salir de la soledad, mientras que la autoridad de los adultos no les proporciona la sensación de ser portadora de porvenir" (Meirieu, 2007: 11).

Esta tensión entre docentes que se manifiestan en disconformidad y alumnos que no logran establecer vínculos con sus profesores afecta determinantemente el clima de las clases, dificultando no solo la transmisión de saberes, sino también la construcción de lazos sociales. Tanto unos como otros suelen redoblar sus apuestas: muchos docentes entrevistados -no todos- han optado por correrse deliberadamente de su lugar como adultos y como educadores, y muchos alumnos entrevistados - no todos- prefieren atender sus propias leyes antes que obedecer las vigentes en la institución educativa donde se encuentran. Es así como se establecen mundos diferentes en un mismo espacio físico. Siendo algo esquemáticos, pareciera que docentes y alumnos encuentran serias dificultades para reconocerse mutuamente como parte de una misma sociedad, de una misma escuela, de un mismo curso; cada posición tira para su lado, incluso cuando esto supone una fuerte disputa -generalmente desarrollada en términos verbales- con la otra parte. De acuerdo con Southwell:

En la escuela secundaria existen entre jóvenes y adultos percepciones muy distintas acerca de lo considerado valioso como saber digno de ser transmitido, distintos usos y valoraciones de las nuevas tecnologías, sensaciones disímiles acerca de la justicia de las reglas escolares, significados divergentes sobre el modo de entender al respeto o de 
interpretar diferentes momentos de la vida escolar; cuestiones todas que profundizan la distancia entre docentes/cuerpo directivo y alumnos (2018: 6). ${ }^{37}$

Estas posiciones, tensionadas, desencontradas y hasta en ocasiones enemistadas, suelen materializarse en una doble consecuencia: por un lado, el retiro de los adultos libera a los jóvenes de las ataduras que supone la presencia de una autoridad que determina qué se puede y qué no se puede hacer; pero, consecuentemente, también los obliga a adentrarse desprotegidos y sin recursos- a una sociedad atravesada por un creciente problema de violencia. El resultado, en términos arendtianos, es el arrojo de las nuevas generaciones a su propia suerte, favoreciendo la constitución de una especie de sociedad juvenil regida por códigos propios y donde, producto de la desatención y la autorregulación, la violencia -en tanto manifestación física desarticulada del orden simbólico- no es percibida como falta, sino como la forma más sencilla y económica de alcanzar un objetivo.

En este panorama de reconfiguraciones y amoldamientos en lo que refiere a la autoridad educativa, surgen algunos interrogantes: ¿Qué sucede, en el ámbito escolar, cuando no hay ninguna figura adulta reconocida como autoridad? ¿Qué reglas se ponen en juego? ¿Cómo se establecen los lazos sociales? ¿Quién determina lo que está bien y lo que está mal, lo que es legal e ilegal, lo que está admitido y lo que está prohibido? ¿Bajo qué parámetros se mide la violencia? ¿Qué sucede con aquellos que no logran adaptarse a las decisiones de la mayoría? Los estudios de Kantarovich, Kaplan y Orce dedicados a la cuestión de la violencia en las escuelas y a los procesos civilizatorios se adentran en estos cuestionamientos del siguiente modo:

Sin vínculos y ligazón social poco sentido tiene el autocoaccionarse. Dicho de otra manera los fenómenos de exclusión que afectan a grandes grupos de sujetos producen una rotura del lazo social, [...] sin el cual no tiene sentido imponerse algún tipo de autocontrol (2015: 61).

Cuando la figura del adulto se desvanece, comienzan a operar otros lazos, otros códigos, otras formas de comunicación -en resumen, otras formas de relacionarse con el otro. El autocontrol o la autocoacción adquieren otro significado: siendo un poco exagerados, actualmente muchos jóvenes no se sienten obligados a rendirle cuentas a un adulto, puesto que no reconocen la diferencia intergeneracional como argumento suficiente

\footnotetext{
${ }^{37}$ Para esquematizar los conflictos entre generaciones, Meirieu (2007) habla del "muerto simbólico de la clase". Resumidamente, el autor hace referencia a aquel que cede o es derrotado en un duelo intergeneracional, en el marco de una clase.
} 
para acatar y obedecer. En cambio es frente al par, al igual -posicionado como líder o cabecilla-, que deben responder por sus actos. Ahora bien, este desplazamiento de la autoridad del adulto al propio grupo representa un peligro aún mayor, puesto que la autoridad del grupo se impone mediante el uso de la violencia e impide cualquier tipo de manifestación singular (Arendt, 1996).

En este sentido, es interesante la perspectiva de un grupo de alumnos pertenecientes a la "escuela del centro", cuando se les preguntó si para ellos la escuela ayuda a resolver los problemas asociados a la violencia. Estos no solo respondieron -convincentemente y al unísono- de manera negativa, sino que además se mostraron renuentes a confiar en la mediación de los docentes, manifestando cierto disgusto producido por las consecuencias que se solían suceder a sus intervenciones. Incluso un miembro del grupo exclamó: "si alguien te mira mal y vos se lo decís al profesor -y el profesor le va a hablar-, entonces después le va a dar más rabia todavía (...) se va a seguir alimentando la bronca de la persona que vos denunciaste". Nótese que el alumno citado en ningún momento introduce el adulto como una presencia ordenadora; por el contrario, la intervención de un docente representa una alteración al funcionamiento del grupo.

Desde otro enfoque, el problema que expone el alumno no se centra en el conflicto inicial ni en los motivos que lo precedieron, sino en el que muy probablemente se sucederá a la intromisión del adulto. Esto representa una violación a las leyes del grupo, y todo aquel que ponga en juego las reglas de su funcionamiento recibirá un castigo mediante la aplicación de la fuerza. Sobre las leyes del propio grupo, Duschatzky y Corea recalcan que "esos nuevos marcos funcionan como usinas de valoraciones y códigos que estructuran la experiencia del sujeto. Es más grave violar las reglas construidas en su interior que las producidas por el dispositivo institucional" (2013: 56). Siguiendo esta línea, resulta oportuno atender a otro diálogo extraído de una entrevista grupal realizada en la "escuela de la periferia norte":

E: ¿Ustedes creen que la escuela ayuda a resolver los problemas de la violencia?

Alumna 1: -No, la escuela no hace nada. ${ }^{38}$

Alumna 2: -Solo llaman a tus papás.

E: -¿Qué hizo la escuela en el caso que me contaron?

Alumna 1: -Llamaron a los padres de una chica y empezaron a decir cualquier cosa.

E: ¿¿Qué opinan de las sanciones que emplea la escuela?

\footnotetext{
${ }^{38}$ Varios alumnos respondieron simultáneamente de manera negativa.
} 
Alumna 2: -Eso no sirve para nada porque volvés con más bronca.

Adviértase que, al igual que en el relato del alumno citado más arriba, la intervención de la escuela es considerada insuficiente, inapropiada y tendiente a acentuar sentimientos de rabia o de "bronca". Para el entendimiento de las jóvenes que hablan, el diálogo con los padres no representa una solución al conflicto: la presencia de estos no resuelve nada, sino que genera una mayor acumulación de resentimiento. La intervención de la escuela supone una distorsión de lo que ellas consideran que sucedió, y por lo tanto, un modo "errado" de resolver sus problemas. El resultado de estas tensiones entre una escuela que intenta resolver una pelea por medio de un llamado a los padres, y unas alumnas que encuentran esta acción como una especie de intromisión ofensiva, es la acumulación de rencor por parte de las últimas.

Sobre las dinámicas y legalidades propias de los grupos autorregulados, vale la pena atender a las palabras de Furlán:

El individuo, al verse prescindible para mantener toda tradición e historia, toma distancia de su comunidad en el marco de un proceso de identificación, que al verse perturbado por la ruptura con los lazos habituales acepta el camino de la regresión volviendo a ritos místicos, mágicos, holísticos, o tomando el atajo de la formación de nuevos grupos cerrados con legalidades propias (2013: 16).

Las opiniones de los educadores sobre la autorregulación de los jóvenes y los acontecimientos comúnmente asociados a la violencia suelen plasmarse en expresiones de impotencia, o en la formulación de hipótesis por las que intentan hallar algún tipo de explicación sobre el fenómeno en cuestión. Los siguientes testimonios de algunos de los docentes entrevistados son representativos:

Enseñamos la no discriminación y sin embargo entre ellos se discriminan, enseñamos la tolerancia y entre ellos son intolerantes, entonces yo creo que hay muchas cosas que ellos viven en sus casas. Viven golpes, abusos, abandonos y todas esas cosas se manifiestan acá, que es el lugar donde le dan bolilla. Yo hace veintisiete años que soy docente y no estoy preparada para soportar eso de la violencia (vicedirectora perteneciente a la "escuela del centro").

A principio del año aparecen las violencias de integración, cada uno de los chicos o las chicas que vienen a la escuela quieren integrarse en un grupo. Entonces aparecen estas cuestiones de quién se quiere empoderar del espacio áulico, quién quiere ser líder de determinado grupo y quiénes vienen de ámbitos diferentes (directora de la "escuela del barrio ferroviario").

Últimamente vienen muchos docentes a hacer catarsis. Están todos viendo de sacarse tareas pasivas, funciones en el ministerio o en algún gremio porque no quieren volver al aula; están todos mal (preceptor perteneciente a la "escuela del barrio ferroviario"). 
Analizando en detalle el relato de los informantes seleccionados, podemos observar que en todo momento -sea por la perpetuación de conflictos domésticos o por disputas entre los propios escolares- pareciera, en términos algo esquemáticos, que los alumnos hubiesen creado su propia autoridad, sus propias leyes, sus propios códigos: una especie de bloque organizado al margen de las reglas que comúnmente rigen en una escuela, y donde la violencia -entendida como una alternativa "más física" que se revela al margen del orden simbólico- no es percibida como infracción o como violación de una norma. El tercer relato representaría la materialización -y dramatización- de esta construcción: posicionándose desde el lugar de víctima, el preceptor entrevistado advierte que el avance de lo que podríamos denominar - con fines analíticos- la "autorregulación juvenil" ha empujado o inducido a muchos docentes a correrse de su tradicional lugar de autoridad y ceder espacios. $^{39}$

Resumiendo: a partir del testimonio de los informantes, pareciera que hoy nos encontramos frente a un desmoronamiento de la autoridad que históricamente descansó en el rol del adulto. Esto no supone la desaparición de la autoridad, sino un desplazamiento fundado en motivos que analizaremos- hacia el propio grupo juvenil.

\section{2 ¿Qué es la autoridad?}

Dadas las confusiones que recurrentemente se suelen evidenciar alrededor de la noción de autoridad, consideramos necesario revisar los sentidos que envuelven al concepto, y, simultáneamente, analizar cómo este se relaciona con $-\mathrm{y}$ se diferencia de- la violencia. ${ }^{40}$

\footnotetext{
${ }^{39}$ La caracterización de los alumnos como los principales culpables de todos los "males" que aquejan a los docentes, revela la persistencia -al menos en el plano discursivo- de un modelo tradicional en el que la imagen del maestro se eleva por encima de los alumnos como una figura "buena", correcta y superior. Al respecto, Greco sostiene: "los tiempos que vivimos, marcados por extremas desigualdades, colocan a muchos niños y jóvenes en problemas y los someten a situaciones dificultosas a menudo sin salida. Sin embargo, con mucha frecuencia todo el análisis parece quedar en la peligrosidad depositada en sus 'identidades' violentas o en la incapacidad de sus retrasos personales. Poco se considera la necesidad de desarrollar 'otra' autoridad posible" (2007: 16).

${ }^{40}$ Inés Dussel ofrece una interesante reflexión para analizar con mayor detalle el vínculo entre los cambios recientes en materia de autoridad educativa y el problema de la violencia: "el discurso de la disciplina, vinculado muchas veces con el de la seguridad ciudadana, construye una asociación entre la relajación de las normas y la crisis de la autoridad adulta, por un lado, así como el incremento de la delincuencia juvenil y la violencia escolar, por otro" (2005: 1111). En línea con la cuestión de la estigmatización mencionada por Kaplan (2009), consideramos que la advertencia de Dussel es sumamente pertinente dado que el estudio de la violencia en las escuelas es una problemática sumamente sensible desde lo enunciativo, no solo por la ya tratada carga negativa que arrastra el término "violencia", sino también por la estrecha conexión con otras temáticas (tales como la legalidad, la seguridad, la convivencia, el conflicto, etc.), cuyos sentidos varían
} 
En otras palabras, dado el desconcierto que envuelve la noción de autoridad -evidenciada en sus múltiples asimilaciones- debemos preguntarnos: ¿qué es la autoridad? ¿Qué lugar ocupa hoy en la escuela? ¿Cómo se vincula con el problema de la violencia? Como primera aclaración, debemos considerar que la autoridad es una construcción histórico-política que intenta brindar estabilidad a las relaciones humanas (Arendt, 2006), pero cuyos elementos constitutivos, así como sus alcances, varían considerablemente en función del contexto social y de la coyuntura temporal. Greco sitúa la autoridad "en una trama de encuentros, allí donde al menos dos -en relación asimétrica- entrelazan sus subjetividades en un tiempo y espacio cultural, histórico, social en común, para perpetuarlos y recrearlos" (2007: 4).

La cuestión de la autoridad constituye un tema central en el desarrollo de la presente investigación, sobre todo cuando asumimos que su reconfiguración afecta en forma determinante la función simbólica y asimétrica que históricamente personificaron los adultos. En este sentido, creemos que las reflexiones de Arendt (1996) nos pueden ayudar a entender mejor qué es la autoridad y de qué manera los cambios que rodean esta cualidad facilitan y promueven la constitución de una sociedad juvenil autorregulada. ${ }^{41}$

Las confusiones entre autoridad y violencia suelen centrarse en una característica compartida, y es que ambos conceptos reclaman obediencia. A pesar de la similitud, la divergencia se halla en los medios por los cuales se lleva a cabo esa demanda: los instrumentos empleados en función de la violencia pueden crear obediencia pero no pueden crear poder ni autoridad. La autoridad se basa en el respeto y el reconocimiento, por ejemplo, en la experiencia de un anciano, en la representatividad de un funcionario o en el saber de un maestro. Así, mientras que la autoridad se fundamenta en la tradición y el reconocimiento, la violencia se basa en el más ferviente individualismo (Arendt, 2006).

radicalmente de acuerdo al punto de vista del observador. Sin perder de vista esta advertencia, y atendiendo a la hipótesis que guía esta investigación, consideramos que el asunto de la autoridad es un elemento constituyente del problema de la violencia en contextos escolares, y que su estudio es necesario para entender los elementos constitutivos del fenómeno estudiado.

${ }^{41}$ Es preciso hacer una aclaración con respecto a la vigencia y la pertinencia de Arendt como referente teórica. Si bien no se desconoce que sus reflexiones sobre la educación fueron realizadas hace más de medio siglo, y que su enfoque evidencia un matiz filosófico que desatiende, entre otras cosas, la mención de datos empíricos o el recorte preciso de un campo de análisis, las recurrentes menciones a su obra obedecen al carácter histórico-político que envuelve su pensamiento. En otras palabras, al asociar la educación con las categorías: sociedad, autoridad, tradición y modernidad, la autora nos ofrece una base teórica para entender que el problema de la violencia no se trata de un fenómeno aislado o un comportamiento atribuible a un individuo, sino que es el resultado de una profunda crisis en el mundo moderno que, lejos de pasar inadvertida en el ámbito educativo, afecta determinantemente sus aspectos constitutivos. 
En un intento por distinguir la autoridad de otros términos, Arendt la define del siguiente modo: "su característica es el indiscutible reconocimiento por aquellos a quienes se les pide obedecer; no precisa ni de la coacción ni de la persuasión. (...) El mayor enemigo de la autoridad es, por eso, el desprecio y el más seguro medio de minarla es la risa" (2006: 62). Un ejemplo vinculado a esta concepción puede hallarse en la relación tradicional que se construye entre padre e hijo: allí el vínculo no supone una dominación por medio de la coacción física, pero sí es requerido un reconocimiento de los roles culturalmente legitimados para ambas partes. Cuando el hijo desobedece alguna norma impuesta por su progenitor, espera, al menos, un reto o un castigo, y de esa manera la restauración de la relación (a sus índices "normales"). De esta manera, padre e hijo cumplen roles basados en la función simbólica que le corresponde asumir a cada uno; claro que las características que acompañan al ejercicio de estos roles pueden variar de una sociedad a otra, o incluso de una familia a otra.

Otro ejemplo puede observarse en la relación entre un maestro y sus alumnos. Desde un punto de vista convencional, quien pretende ejercer la enseñanza en el marco de una escuela solo puede hacerlo si los alumnos creen y aceptan el lugar del profesor como portador de un saber $-\mathrm{y}$ de las estrategias más adecuadas para su transmisión- que lo diferencia de sus alumnos.

En estos casos, la fuente de autoridad reside en el reconocimiento en base a la potencialidad de crecimiento y enriquecimiento que esa relación ofrece para una de las partes implicada. [...] La educación se sustenta en la autoridad de una tradición que exige ser preservada y como toda autoridad, supone relaciones asimétricas (Di Pego, 2016: 945948).

Cuando esto no sucede, cuando los alumnos creen que un profesor no domina un saber ni los medios para transmitirlo, la autoridad del enseñante se diluye a causa del descreimiento y la desconfianza. Arendt destaca que, desde mediados del siglo XX, no solo el rol del maestro se encuentra en crisis, sino también el del adulto en general. ${ }^{42}$

Una de las principales consecuencias de esta crisis es la desatención y desprotección de las nuevas generaciones. Bajo el discurso de la autonomía, del autogobierno, de la

\footnotetext{
${ }^{42}$ Cabe destacar que la filósofa no pensaba en una crisis localizada, ni en los problemas de algunas escuelas en particular; la crisis se encontraría asociada a una constante y creciente obsolescencia de los sistemas educativos modernos y a cambios vertiginosos en el reconocimiento generalizado de la autoridad como elemento estabilizador de las relaciones humanas.
} 
independencia, niños y jóvenes fueron ubicados en un lugar privilegiado y al mismo tiempo descuidado:

La autoridad que dice a cada niño qué tiene que hacer y qué no tiene que hacer está dentro del propio grupo infantil y, entre otras consecuencias, esto produce una situación en la que el adulto, como individuo, está inerme ante el niño y no establece contacto con él. Sólo le puede decir que haga lo que quiera y después evitar que ocurra lo peor (Arendt, 1996: 192-193).

Extremando esta línea argumentativa, podríamos decir que desde mediados del siglo XX nadie sabe bien qué es la autoridad, qué función cumple y por qué es necesaria para la convivencia humana. Esta cualidad, afirma Arendt, "brindó al mundo la permanencia y la estabilidad que los humanos necesitan justamente porque son seres mortales" (ibíd.: 105); sin embargo, desde que se desvaneció el fundamento romano que originalmente acompañaba el significado de la autoridad, dicho concepto hoy puede ser fácilmente convertido en cualquier otra cosa. En verdad, su significado puede rastrearse en la filosofía política griega y su posterior acepción romana, más específicamente en el valor simbólico que estas sociedades le asignaron a las leyes para el ordenamiento de la polis. Esta preocupación de los griegos por utilizar instrumentos de gobierno más eficientes y estables que la coacción explícita (es decir, alternativos al uso de la violencia) dio como resultado la creación de las leyes y de la autoridad. En pocas palabras, la autoridad fue pensada originalmente por los griegos y reforzada posteriormente por los romanos como el marco legitimador necesario para asegurar, mediante la distribución -y el reconocimiento- de roles específicos, el funcionamiento de las leyes.

El valor de la autoridad fundada por los griegos para el control de las sociedades halló su réplica inmediata en manos de la Iglesia Católica, que vio en el uso de esta cualidad un recurso fundamental para llevar a cabo el control por medio del poder ligado al valor de las creencias (los fundamentos bíblicos de la religión cristiana suplantaron las leyes griegas manteniendo el uso de la autoridad como herramienta fundamental para legitimar el gobierno del clérigo). En términos de Arendt, "gracias a que la fundación de la ciudad de Roma se repitió en la fundación de la Iglesia Católica -aunque, por supuesto, con un contenido radicalmente distinto-, la era cristiana se apoderó de aquella trinidad romana de religión, autoridad y tradición (1996: 138).

El devenir histórico-político de la modernidad -a pesar de sostener la autoridad como recurso para intentar asegurar el funcionamiento de las leyes y la creencia en sus 
representantes- reescribió el valor y el significado del término. Desde comienzos del siglo $\mathrm{XX}$, la influencia de la autoridad en el espacio político se prestó a diversas confusiones y abusos respecto de sus cualidades como recurso para la legitimación del dominio. Entre esas confusiones, Arendt destaca el entrelazamiento de la autoridad con la violencia como una de las más preocupantes, puesto que el significado original del término intentaba alejarse de los instrumentos de la violencia. ${ }^{43}$ La autora mencionada explica:

La autoridad siempre demanda obediencia y por este motivo es corriente que se la confunda con cierta forma de poder o violencia. No obstante, excluye el uso de medios externos de coacción: se usa la fuerza cuando la autoridad fracasa. Por otra parte, autoridad y persuasión son incompatibles, porque la segunda presupone igualdad y opera a través de un proceso de argumentación. [...] Ante el orden igualitario de la persuasión se alza el orden autoritario, que es siempre jerárquico (Arendt, 1996: 102).

\subsection{Debates en torno a la asimetría de la autoridad}

Hasta aquí analizamos la autoridad desde una perspectiva que podríamos denominar tradicional, es decir, como una construcción con ciertos caracteres fijos y enraizados en la jerarquización y la asimetría. Ahora bien, ¿qué ocurre en el ámbito educativo actual con respecto al reconocimiento de la autoridad vinculada al rol docente? Si bien no caben dudas de que la autoridad es un elemento constitutivo de la educación, está claro que esta construcción hoy demanda mucho más que "un título". Las relaciones asimétricas que históricamente se establecieron entre docentes y alumnos hoy se muestran alejadas, desencontradas y, en algunos casos, enfrentadas. Los maestros no cuentan con una voz autorizada para pararse frente a sus alumnos con la certeza de que su posición como profesionales de la educación constituya un argumento suficiente para que estos obedezcan. En la sociedad argentina contemporánea, la situación de la autoridad y la asimetría no distan mucho del escenario que planeta Arendt en relación a las disputas y los malos entendidos. Sin pretender transpolar los estudios de la autora citada de forma automática al ámbito regional, las confusiones que rodean a la autoridad, sus roces con la violencia y, en general, la reconfiguración del esquema jerárquico y verticalista que históricamente

\footnotetext{
${ }^{43}$ Por citar solo un ejemplo respecto a esta confusión entre violencia y autoridad: la última dictadura militar argentina (1976-1983), además de intentar restituir valores conservadores aplacando la participación política de determinados sectores, también intentó restaurar la supuesta autoridad perdida de las instituciones empleando recursos vinculados al terror y la violencia. Estos elementos de coacción estuvieron acompañados por la aplicación de torturas sistemáticas, llevadas a cabo en diversos centros clandestinos de detención. Los objetivos de la dictadura se centraban en la "reorganización" del presunto caos político que caracterizaba a Argentina hacia mediados de la década de 1970.
} 
posicionó al docente por encima del alumno, son algunos de los condicionantes que caracterizan a la educación argentina actual.

Los debates por la asimetría y los modos en que los maestros deberían posicionarse frente a sus alumnos -y cómo este posicionamiento puede afectar la convivencia- suelen evidenciar dos tendencias antagónicas. Por un lado, algunos educadores y pedagogos sostienen y refuerzan la idea de que la autoridad debe ser siempre vertical, asimétrica y aceptada -sin reclamos- por los alumnos. "Algunos discursos la reclaman nostálgicamente en su formato habitual, asociado a un orden jerárquico inconmovible, hecho de lugares de superioridad instalados sobre lugares de inferioridad" (Greco, 2007: 4). Por el otro, están aquellos que consideran que este posicionamiento "clásico" en materia de autoridad desatiende una serie cambios socio-históricos acontecidos en las últimas décadas, y que el ejercicio de una autoridad en términos tradicionales solo puede generar un "choque" con las nuevas generaciones. Para estos, la autoridad puede ser ejercida desde la igualdad y sosteniendo una posición no ortodoxa con el saber: "la autoridad queda así reformulada, reubicada, desplazada de su tradicional plano de superioridad, interrumpida la jerarquía que le ha otorgado siempre un lugar "por encima de"" (ibíd.: 12). En línea con las confusiones que rodean a la autoridad, es oportuno atender a las opiniones de una de integrante de un Equipo de Orientación escolar (perteneciente a la "escuela de la periferia norte") y de una integrante del Equipo Distrital de Infancia y Adolescencia:

La realidad es que a veces en esta escuela el profesor se pone en el lugar de la autoridad en una relación asimétrica... "iporque soy el docente vos me tenés que escuchar!" Se genera digamos... una especie de maltrato.

La autoridad se construye, el hecho de que yo tenga un cargo no me da la autoridad. Según los chicos, es alguien que les genera confianza, que los escucha, alguien que cumple su palabra, alguien que está. Nosotros trabajamos mucho la cuestión del referente para el grupo, alguien que esté cerca y que para ellos sea importante, hoy la autoridad se construye desde ahí. A los chicos la autoridad del director no les importa.

Los fragmentos citados no solo advierten que los esquemas convencionales en materia de autoridad se muestran obsoletos para brindar respuestas a las problemáticas que deben enfrentar los jóvenes de hoy, sino que además pregonan por una reformulación del concepto; ya no desde la asimetría, sino desde cierta horizontalidad o igualdad de derechos. Al respecto, resulta pertinente atender los aportes de Bleichmar, quien se adentra en la cuestión de la asimetría y ofrece una explicación para tratar de entender mejor la controversia que envuelve al concepto: 
La cuestión de la asimetría nos preocupa no solamente en relación con los jóvenes, se está planteando como preocupación en todos los modelos [...]. En la Argentina, a partir de los modos en los que se ejerció el poder despótico durante muchos años, hay una cierta desvalorización de la asimetría (Bleichmar, 2008: 143-144).

La autora citada vincula los problemas que se evidencian hacia el interior de las instituciones educativas con los cambios políticos que marcaron la historia reciente del país, y le otorga a la cuestión de la asimetría un lugar central. Completando la cita: "quienes tienen que ser responsables no se hacen responsables, como si hubiera un temor de que al ejercer la asimetría se ejercieran modelos autoritarios, cuando la asimetría lo que implica son formas de responsabilidad" (ibíd.: 143).

Duschatzky y Corea también reflexionan sobre las modificaciones en la autoridad y la reconfiguración de los roles familiares. En sus propias palabras:

En el entorno familiar es visible la indiferenciación de los lugares tradicionales de padre, madre e hijo, con la consecuente disolución de las posiciones de protección y autoridad de los padres hacia los hijos [...]. En las ruinas de esa experiencia histórica vemos emerger nuevas relaciones que no sólo ponen de relieve la simetrización o indiferenciación de lugares sino más bien la pérdida de toda referencia en la cual anclar [...]. Por lo tanto, cualquier sistema de referencias que se arme conlleva la oportunidad de un proceso subjetivante (2013: 73-74).

En los últimos años, varios factores influyeron sobre la asimetría que históricamente separó a los jóvenes de los adultos: la crisis institucional, ${ }^{44}$ el temor al ejercicio de la autoridad, la disolución del rol adulto y la constitución de una sociedad juvenil. Por estas razones, si "antes la infancia estaba preservada de las preocupaciones de los adultos, en cambio en la actualidad los chicos reciben las tensiones de los adultos como picotazos" (Meirieu, 2007: 3). Los jóvenes, despojados de la protección de los mayores, se ven obligados a crear sus propias reglas, obedecer sus propias jerarquías y habitar sus propios espacios.

\footnotetext{
${ }^{44}$ En la caracterización de las violencias escolares que propone Di Leo también se hace mención a la crisis institucional como uno de los componentes centrales de la problemática. En sus palabras: "el progresivo retiro y/o crisis de las instituciones estatales deja a los jóvenes, especialmente a aquellos en situación de vulnerabilidad o desafiliación, sin las herramientas simbólicas y materiales básicas para constituirse como sujetos [...]. Para estos individuos, las instituciones han dejado de ser anclajes de proyección de un futuro y de construcción de identidades narrativas, de un orden simbólico integrador" (2008: 21). Siguiendo la línea del autor recién citado, creemos que el debilitamiento de la escuela como principal espacio de referencia y constitución de subjetividades desencadenó un proceso de blindaje dentro del propio grupo de jóvenes. Asimismo, este proceso de encapsulamiento supone una relación de enemistad o enfrentamiento -que muchas veces se manifiesta en el plano físico- con lo que se considera exterior: la escuela y sus agentes.
} 


\subsection{Autorregulación}

Bajo la dominación del adulto, el joven se hallaba en una relación de inferioridad y debía obedecer -o rebelarse- frente a una figura individual, jerárquicamente superior y con claras ventajas físicas y simbólicas. La fortaleza del padre, del maestro o de cualquier adulto históricamente estuvo asentada sobre un consenso generalizado, sobre un acuerdo tácito de dominio. Bajo el dominio del grupo, de la mayoría absoluta, en cambio, el joven debe enfrentarse a los de su propia clase: debe entablar una lucha contra un bloque que se organiza en torno a sus propios códigos, que es solidario entre sus miembros y que excluye a quienes se hallan fuera de su unidad.

Dentro del grupo, [...] el niño está mucho peor que antes, porque la autoridad de un grupo, aun de un grupo infantil, siempre es mucho más fuerte y más tiránica de lo que pueda ser la más severa de las autoridades individuales. Si se mira desde el punto de vista de cada niño, sus posibilidades de rebelarse o de hacer algo por su cuenta son prácticamente nulas (Arendt, 1996: 193).

Al liberarse de la dominación del adulto, entonces, el joven queda sujeto a la dominación del grupo; las reglas que imperan en esta lógica responden a un orden tiránico, esto es, a la hegemonía de un líder o una minoría dominante en lo que respecta a la toma de decisiones importantes para asegurar su funcionamiento. Bajo este tipo de dominio se establecen la sumisión y la obediencia como los únicos comportamientos aceptados, al mismo tiempo que se iguala a los sometidos por su condición de inferioridad. Arendt habla de una posición desesperada dado que no existe posibilidad de rebelarse, de manifestarse individualmente. Un joven, bajo estas condiciones, representa "una minoría de uno enfrentada con la mayoría absoluta de todos los demás" (Arendt, ibíd:: 193). En otras palabras, entre los mandados no hay diferencias, todos carecen de poder, todos son inferiores con respecto a quienes toman las decisiones:

Al emanciparse de la autoridad de los adultos, el niño no se liberó sino que quedó sujeto a una autoridad mucho más aterradora y tiránica de verdad: la de la mayoría. En cualquier caso, el resultado es que se desterró a los niños, por decirlo así, del mundo de los mayores; es decir que quedaron librados a sí mismos o a merced de la tiranía de su propio grupo, contra el cual, a causa de la superioridad numérica, no se pueden rebelar (Arendt, 1996: 93).

En este contexto, la violencia constituye uno de los medio más eficaces para imponer la voluntad de los líderes; este recurso puede llegar a naturalizarse como un instrumento propicio para materializar una relación de dominación y sometimiento. La 
utilización del sometimiento físico - por parte de los cabecillas- marca la diferencia con los dominados. Cuando los alumnos entrevistados hablan de "cagarse a trompadas" o de "agarrarse a piñas", posiblemente se están refiriendo -con los recursos que disponen- a ser reconocidos dentro del grupo, demostrar que son lo suficientemente "duros" como para ser respetados, reclamar la posesión de algo o de alguien, disputar un liderazgo, etcétera. La resistencia a obedecer las órdenes impuestas por los cabecillas supone la aplicación automática de tormentos. Desde amenazas verbales hasta la agresión con armas, todo puede ocurrir, incluso bajo la mirada de los adultos; muchos de estos - no todos- prefieren, sea para autopreservarse o eludir responsabilidades, permanecer indiferentes.

A esta altura consideramos pertinente atender el testimonio de uno de los directivos (perteneciente a la "escuela del barrio ferroviario"), quien, en línea con lo desarrollado en el párrafo anterior, advierte sobre la determinación o la dureza que hipotéticamente emplearían los alumnos si pudieran tomar decisiones -autónomamente-, sobre el tipo de sanciones que aplicarían a sus pares:

Cuando uno le consulta al grupo de adolescentes, estos son muchos más rígidos en las sanciones que nosotros los adultos. Cuando no es para sí mismo, quieren que al otro que los molesta, o que no le permite aprender, o los está agrediendo, reciba una sanción seria. Si uno le preguntara al grupo de adolescentes: ¿qué sanción debería tener un chico que golpea a otro? Lo más probable es que quieran romperle la cabeza o expulsarlo de la escuela. $^{45}$

Si nos adentramos un poco más en las reflexiones de Arendt (1996), hallamos que la constitución de una sociedad puramente juvenil representa una artificialidad, una construcción específicamente contemporánea que exacerba la independencia de los jóvenes hasta llegar a un punto en que tal construcción ha llegado en convertirse en un peligro para ellos mismos. Aquí es preciso introducir una pregunta originalmente formulada por Meirieu: “¿Por qué los jóvenes aceptan la autoridad tan dura y violenta, la autoridad clánica de los grupos en los cuales se encuentran, mientras que se rehúsan a la autoridad de los adultos?" (2007: 11). Podría decirse que esto ocurre posiblemente porque el grupo -incluso

\footnotetext{
${ }^{45}$ Con respecto a las sanciones, no es un dato menor el hecho de que la permanencia no sea algo que se ponga en juego cuando los alumnos deciden aplicar sus propias leyes. Dado que la exclusión del sistema educativo público atenta, justamente, contra el derecho a la educación, varios adultos entrevistados advirtieron que algunos alumnos, conscientes $-\mathrm{y}$ haciendo abuso- de este derecho, aprovechan la garantía de permanencia para manifestarse "violentamente" desatendiendo la consecuencia sus actos. Sobre la determinación o "dureza" de los jóvenes en la hipotética aplicación de sanciones, véase: Patierno (2014).
} 
conformado bajo modalidades tiránicas de dominio- tiene algo para ofrecer que los adultos ya no les proporcionan:

La banda es un refugio, sobre todo en el contexto de una insuficiencia familiar, donde contribuye a apuntalar un sentimiento de identidad a falta de cimientos más sólidos, y autoriza el pasaje al acto en una sensación de obviedad, disolviendo las interdicciones morales, a veces bajo la égida de un jefe convertido en figura identificatoria (Le Breton, 2017: 39).

El adulto ha tomado una posición hipócrita: en primer lugar libra a las nuevas generaciones a su propia suerte, y luego se consterna cuando, producto de la autorregulación, un joven resulta herido o pierde la vida. Este es el camino que parecen haber tomado muchos adultos vinculados en algún punto con la profesión docente: saben qué hacer (desde un punto de vista burocrático y legal) frente a un hecho considerado violento por la comunidad escolar y también saben cómo recomponer rápidamente la rutina; pero estas medidas no interpelan las causas que arribaron a la resolución violenta de un conflicto, solo sirven como parches o remiendos temporales. Más adelante se ampliará sobre este tema.

El trabajo de Duschatzky y Corea es relevante en lo concerniente a la autorregulación de los jóvenes y a los riesgos a los que estos se ven expuestos. Las autoras encuentran en la autorregulación, o la conformación de bandas (como ellas lo llaman), la instauración de nuevas formas en las que los jóvenes habitan la inmediatez y la necesidad. Las autoras identifican la "fraternidad", el "aguante", "la fidelidad", "la creación de valores propios" y "la percepción constante del riesgo" como los elementos que caracterizan el autogobierno de los jóvenes:

Solo me debo al próximo, el que comparte mi circunstancia, con el que establezco fidelidades y reglas de reconocimiento recíproco. El otro, el par, y no la autoridad simbólica inscripta en la tradición, el saber y la legalidad estatal, puede anticipar algo de lo que va a suceder porque ha vivido en la inmediatez que compartimos (Duschatzky y Corea, 2013: 34).

Recapitulando, podría decirse el aumento de una sociabilidad cerrada entre pares se produce por la necesidad de afirmar la propia identidad en un contexto en el que el lazo social y la autoridad del adulto atraviesan una serie de cambios determinantes. Siguiendo esta línea, creemos que hoy en día resulta muy difícil advertir, tanto en jóvenes como adultos (en contextos escolares), un reconocimiento consensuado del nosotros, esto es, un reconocimiento generalizado de país, de comunidad, de barrio, de escuela, de curso. En contraposición, muchos jóvenes han tenido que enfrentarse a un estado de aislación creando 
un mundo propio, un artificio caracterizado por "un proceso de encapsulamiento en el propio grupo y enfrentamiento con el exogrupo" (Kornblit, 2008: 11). Creemos que este cierre o encapsulamiento promueve el establecimiento de códigos intrínsecos en los que la violencia -entendida como una opción "más corporal" que se produce a causa de la escasez de recursos simbólicos- no representa una trasgresión, una excepción, sino un modo "corriente" de resolver las diferencias.

A modo de cierre consideramos conveniente atender una vez más las palabras de Kornblit:

La pérdida de poder de anclaje de las instituciones deja a muchos jóvenes a la deriva, sin otro asidero más que el del pequeño grupo de pertenencia, cuya identidad se construye por oposición a la de otros grupos similares, con los que resulta necesaria la confrontación como medio de reafirmación (ibíd:: 11).

\subsection{La influencia del contexto}

De acuerdo a la hipótesis presentada, menos autoridad supone más violencia; pero esta conjetura no remite a ninguna clase de esencialismo. El corrimiento del adulto y la consecuente desprotección del joven no suponen un pasaje automático a la violencia; no se trata de la manifestación de un instinto o el despertar de alguna conducta innata. Para Arendt, "la violencia ni es bestial ni es irracional" (2006: 84); esto nos lleva a considerar, en términos generales, que es la propia sociedad -despreocupada por el destino de los jóvenes-, la que crea condiciones "primitivas", "salvajes", donde opera la ley del más fuerte y se excluye a quienes no logran adaptarse. Hace más de medio siglo, la misma autora presagiaba:

Es evidente que en la vida pública y en la vida política la autoridad no tiene ningún papel. En la educación no puede haber tales ambigüedades ante la actual pérdida de autoridad [...]. Los adultos desecharon la autoridad [...], se niegan a asumir la responsabilidad del mundo al que han traído a sus hijos (Arendt, 1996: 201).

Siguiendo esta línea, podría decirse que el problema de la violencia en las escuelas no puede reducirse a un caso específico, ni tampoco puede volcarse a un individuo aislado, sino que se centra en el contexto histórico-político que caracteriza a nuestra época: capitalismo, individualismo, competencia, autosuperación, intolerancia, indiferencia, egoísmo, triunfalismo. Estos condicionantes sociales conforman un terreno adverso para los más jóvenes, quienes deben adentrarse sin el cuidado de los adultos: 
Una sociedad ya injusta al marginarlos, los ha transformado en sus enemigos, niños y jóvenes que se viven amenazantes por su violencia o inhabilitados por sus incapacidades, [...]. No se advierte, en un sentido general, un "hacerse cargo" social, institucional, adulto que perciba que esos y esas, todos "sus" niños, niñas y jóvenes son su responsabilidad, el sentido de sus instituciones y sus acciones (Greco, 2007: 17).

En este encuentro directo de los jóvenes con un mundo que pareciera prescindir del consenso y el lazo social, la violencia no es una excepción sino un recurso necesario para sobrevivir. Duschatzky y Corea hacen hincapié en una serie de cambios acontecidos en la modernidad tardía, entre los que se destacan el encuentro con nuevos -y cada vez más desafiantes- retos para la consolidación del vínculo y la consecuente variación en la constitución de los sujetos. Así,

Mientras en el marco de los Estados-nación y en las coordenadas de una cultura moderna el sujeto devenía tal por acción de los dispositivos familia y escuela, hoy en el contexto de la centralidad que ha cobrado el mercado y la caída hegemónica de los Estados-nación el suelo de la constitución de los sujetos parece haberse alterado (2013: 32).

Centrando la atención en la Argentina de las últimas décadas, es innegable el hecho de que la sustitución del estado de bienestar por la lógica del mercado representó, entre otros cambios severos, radicales y económicamente despiadados, la "liberación" económica -y consecuente desprotección- de las clases trabajadoras. El ascenso del mercado supuso la desatención de ciertas funciones históricamente asociadas al cuidado de las masas, y el estado se retrajo en favor de un liberalismo salvaje (conocido en la década del noventa como "neoliberalismo"). Este esquema sociopolítico caracterizado por la descentralización y la desregulación, lejos de garantizar una equitativa repartición de la riqueza, desató una creciente polarización material y simbólica entre los que más y los que menos tienen. Siguiendo a Furlán, "el mercado se constituye en el regulador de la vida por excelencia, y el egoísmo se convierte en el sentimiento característico en toda interacción social” (2013: 14).

Los efectos negativos de los nuevos condicionantes socioeconómicos en la vida de los jóvenes fueron mencionados en forma recurrente por varios entrevistados adultos. Al respecto son oportunos el relato de una integrante de un Equipo Distrital de Infancia y Adolescencia, y el de un profesor de Construcción de la Ciudadanía (perteneciente a la "escuela del centro"):

Creo que a veces las condiciones socio-económicas son violentas. En general se piensa que los portadores de la violencia son los jóvenes y en realidad la provocación existe cuando las expectativas de la cotidianeidad no están cubiertas, ahí estamos hablando de otras violencias. Creo que los jóvenes no son violentos sino que hay que pensar desde lo sociológico y en cómo el sistema te provoca. 
Vienen de contextos muy humildes donde la violencia es el lenguaje cotidiano [...]. Esta es una sociedad de consumo y, aunque a vos te parezca mentira, genera violencia. El ultra comercio y el ultra capitalismo no ayudan. La sociedad de consumo no ayuda; hoy se nota el chico que tiene frente al que no tiene.

En un marco social donde el otro constituye un obstáculo y la acción va delante de la palabra, la violencia pareciera constituir un recurso generalmente empleado para, siguiendo a Bleichmar, sostener un férreo individualismo en el que se exalta la premisa de "salvarse solo, a costa de lo que sea" (2008: 39). Sobre los efectos nocivos de este proceso que, con fines analíticos, podríamos denominar "individualismo contemporáneo", Furlán afirma: "la premisa de todo vale lleva a la dispersión del universo simbólico tradicional precipitando al sujeto a conductas del orden de la impulsividad y del cuerpo a cuerpo" (2013: 14). ${ }^{46}$ Estas respuestas automáticas, físicas, impulsivas, reaccionarias -en pocas palabras, escindidas del orden simbólico-, en ocasiones no solo no son reprimidas, sino que, bajo el yugo del todo vale, incluso son celebradas. Siguiendo esta línea podemos citar el testimonio de una directora (con tareas en la "escuela del barrio ferroviario"):

Hay familias que se angustian muchísimo porque sus hijos o sus hijas han participado en una acción de violencia o una falta de respeto y hay otras que hemos visto que hasta los alientan. Dicen: "si no te entiende, pegale una buena piña", y bueno nosotros siempre explicamos que nadie entiende nada a partir de un golpe. Jamás una persona pudo aprender nada a partir de un golpe, un manotazo, un insulto, sino que todos aprendemos a partir de la cordialidad y del buen trato.

Lejos de reconocer y respetar las instituciones y las autoridades tradicionales (familia, escuela, estado), los adultos defensores de la violencia promueven la constitución de un nuevo tipo de subjetividad. En esta lógica, los jóvenes establecen un modo de relación con el mundo en el que no son capaces de reconocer límites, porque (siendo un poco dramáticos) son sus propios padres quienes los alientan a transgredirlos. En este punto resulta interesante atender las reflexiones de Noel:

Aquellos que trabajamos habitualmente en escuelas de barrios populares estamos familiarizados con las complejas situaciones que surgen de estas discrepancias sobre la legitimidad del uso de la fuerza física: padres que demandan a los docentes que castiguen físicamente a sus hijos, docentes que se horrorizan ante la demanda de los padres (a los que tachan de "brutales" o "ignorantes", para decirlo de modo elegante), padres que se horrorizan de la inacción de los docentes (a los que califican de "cómodos" o "incompetentes"), alumnos para quienes las admoniciones, reflexiones o llamados a la

\footnotetext{
${ }^{46}$ Esta despiadada búsqueda del éxito individual se evidencia, por ejemplo, en algunas organizaciones de fútbol infantil, donde los niños son enviados desde edades cada vez más tempranas y son alentados a competir bajo un sistema de torneos que promueven el triunfo a cualquier precio. Aquí padres y entrenadores se corren del lugar de autoridad ya que no ofrecen protección alguna; por el contrario, promueven y alientan el precoz ingreso a una competencia cruda justificándose en la búsqueda de un resarcimiento económico futuro.
} 
vergüenza (o alguno de sus equivalentes como el amor propio, el honor o el respeto) resultan incomprensibles o irrelevantes, de modo tal que ven a los docentes como "blandos", cuando no lisa y llanamente "estúpidos" por su resistencia a castigar o a respaldar sus castigos haciendo uso de la fuerza (2006: 41-42).

La reconfiguración de la autoridad escolar y, sobre todo, la indiferencia de algunos adultos representan dos de los factores más preocupantes en lo concerniente al problema de la violencia en las escuelas. Centrando la atención en el segundo elemento, creemos que la indiferencia, la no intervención, el silencio o la desatención, podrían considerarse actitudes o respuestas tendientes a crear $-\mathrm{y}$ a consolidar- un vacío de autoridad que afecta no solo la asignación de los roles y el reconocimiento de las normas, sino la convivencia en general de todos los actores presentes en la escuela. En este vacío no queda claro lo que se puede y lo que no se puede hacer, lo que está bien y lo que está mal, lo que es legal e ilegal. Como plantean Duschatzky y Corea, "el docente es con frecuencia la figura de ese que no escucha, que no entiende, que no reconoce" (2013: 63). Si bien pareciera que el ejercicio de la docencia actualmente se encuentra atravesado por cierta desvalorización simbólica y material, la propia desautorización, esto es, la evasión de responsabilidades y la lógica del mínimo esfuerzo, marcan una peligrosa ruptura con los valores que históricamente estuvieron vinculados a la enseñanza.

$\mathrm{Al}$ atender el testimonio de los informantes adultos, es evidente que en las escuelas estudiadas coexisten una multiplicidad de discursos y valoraciones en lo que refiere a la autoridad escolar. Como dijimos más arriba, algunos critican la postura de aquellos docentes que pretenden -nostálgicamente- recuperar o sostener cierta noción de autoridad "tradicional", como muestran los testimonios de dos integrantes de un Equipo Distrital de Infancia y Adolescencia, una preceptora (perteneciente a la "escuela de la periferia norte") y un preceptor (perteneciente a la "escuela del barrio ferroviario"):

El profesor pretende posicionarse en un lugar que hoy ya no existe; tiene que trabajar desde otros lugares. [...] Eso eliminaría mucha violencia dentro del aula.

Hoy los jóvenes tienen una posición mucho más fuerte. Antes la posición era de acatamiento, con toda la bronca del mundo, pero ahora el chico se para y le contesta que no, y no, y no y no.

Para mí los más violentos son los docentes con la actitud que tienen frente al alumno. Porque el alumno reacciona en respuesta... te rompen el auto, te lo rayan, te putean, te escupen... pero si vos les hiciste algo.

Tiene que haber ciertos acuerdos y me parece que ahí hay un corrimiento del adulto que está en crisis. 


\subsection{La indiferencia de los adultos}

En términos generales, el ejercicio de la docencia también se encuentra atravesado por grandes cambios. Estos se evidencian fundamentalmente en las múltiples, imprevisibles y

desgastantes funciones que deben desempeñar -sobre todo- los nuevos profesionales, quienes, para ingresar al sistema educativo público, deben adentrarse a un terreno altamente burocrático y competitivo que no goza de reconocimiento estatal en términos económicos, ni es valorado socialmente como lo fue en otros tiempos. De acuerdo con Kantarovich, Kaplan y Orce: "Los docentes forman ellos mismos parte del sufrimiento social a la vez que su misión consiste en acompasar el sufrimiento social de los alumnos, lo cual genera la necesidad de analizar la incidencia de esta situación en la vida cotidiana de las escuelas" (2015: 68).

La figura del maestro errante, sistematizada por Duschatzky (2007), resume algunos de los obstáculos que debe atravesar un docente en la actualidad: cargos temporales, traslados constantes, salarios mínimos, escasez de materiales didácticos, clases superpobladas, descontento de los padres, capacitación no remunerada y trabajo adicional, entre otros. Al respecto, Southwell afirma: “antes que docentes somos ciudadanos que nos insertamos y vinculamos con una sociedad poniéndonos en diálogo con sus tendencias, sus problemas, sus urgencias, sus dilemas" (1999: 172). Lejos de tratarse de un asunto secundario, creemos que estas nuevas y complejas dificultades -sumadas a la desconsideración estatal y el desprestigio social- repercuten seriamente sobre la cuestión de la violencia.

A la desvalorización social del rol docente se suma, en muchos casos, la oposición familia/escuela (Kornblit, 2008), donde algunos padres -desconformes con el desempeño profesional de los profesores- han llegado a manifestar su descontento adoptando una actitud reñidora, "defendiendo" a sus hijos y apelando en ocasiones a la confrontación física. En este panorama de pauperización laboral y descrédito social, es habitual que, de acuerdo a varios testimonios (proporcionados por los adultos), muchos docentes manifiesten hoy sus reclamos a través de cierto "boicot profesional" o, dicho de otro modo, un deliberado descuido de sus responsabilidades; pero este comportamiento, lejos de pasar inadvertido, expone varias falencias en el ejercicio de la profesión y, lo que es más 
preocupante, revela la permanencia de cierto descuido o desatención sobre el accionar de los alumnos. En esta línea se destacan una serie de testimonios, los cuales revelan la presencia de un mecanismo de "autodefensa" o "evasión” que, con fines analíticos, podría resumirse en la noción de "indiferencia":

Están todos traumados, preocupados por la situación, buscan la comodidad y yo los entiendo. $\mathrm{Y}$ eso hace que no se jueguen... que muchos docentes aprueben y aprueben alumnos para sacárselos de encima. Y a mí me lo han dicho. No los quieren desaprobar porque no los quieren tener de nuevo, no los quieren hacer repetir. Se los quieren sacar de encima porque se quieren sacar de encima a los padres [...]. Y aparte porque no se quieren comer una denuncia, porque un día desaprobaste a un pibe y ya al otro día sos un violador [...]. Esas cosas son las que me duelen un poquito, el docente también siente... no tener la oportunidad de decir "hoy no quiero ir porque tengo miedo", ponele [...]. Pasa que todo el mundo tiene miedo. En mi caso no me da tanto miedo porque la educación no es mi única entrada de dinero (preceptor, "escuela del barrio ferroviario").

Hay profes cansados. Profes que corren de acá para allá en una especie de vorágine... entonces vienen acá, se sientan y esperan que el chico rinda, haga, proponga, sea creativo (vicedirectora, "escuela de la periferia norte").

Creemos que el descontento con las condiciones laborales repercute determinantemente en la convivencia escolar. Muchos docentes optan por refugiarse en el rol de espectadores, de observadores inermes frente a cualquier acontecimiento; para estos profesores agotados, sobrecargados, indiferentes, las dificultades asociadas a la convivencia no son una prioridad, porque, exagerando un poco, difícilmente estos dispongan del tiempo y la predisposición para, al menos, tratar de entender las preocupaciones -y las reaccionesque manifiestan sus alumnos.

El deliberado abandono del lugar de autoridad genera un emplazamiento vacío de significado; el trabajo docente se reduce entonces a lo que podría considerarse una asistencia, un acompañamiento, o, en otros términos, a ser alguien dispuesto para, sencillamente, "evitar que se maten”. Como señala Southwell, "la docencia -como tarea y como rol social- es una de esas prácticas sociales que se han sedimentado y cuyos puntos de origen, así como las decisiones que contribuyeron a su conformación, se han ido volviendo menos evidentes" (1999: 170). Eludir las responsabilidades generacionales y éticas que deberían asumir adultos y educadores representa un debilitamiento en la relación -y en las diferencias- que debería existir entre adultos y jóvenes. Lejos de favorecer la autonomía o la independencia, creemos que la indiferencia de los adultos habilita la sustitución de códigos y el retraimiento de los jóvenes hacia el propio grupo de pares, 
afianzando la consolidación de un mundo "artificial", autorregulado por estructuras en cierto modo clánicas o tiránicas.

La relación entre adultos y jóvenes hoy parece haberse reconfigurado; en términos exagerados, pareciera que es el adulto quien debe adaptarse a las demandas del joven. Decir "no" genera temor; temor a dejar de ser un adulto "copado", es decir, alguien que es, convenientemente, bienvenido y aclamado entre jóvenes. Tal como relata el preceptor citado más arriba:

Uno tiene que ser firme y tiene que mostrar cierto grado de autoridad y no está bueno eso, porque después se siguen generando roces, los pibes se acuerdan y el pibe no le importa si vos tuviste razón o no... a mí me pone mal haberle puesto un límite a una persona, porque después se genera un roce con esa persona. Y por lo general se genera un roce con el grupo; además, muchas veces terminás quedando solo cuando hay algún problema.

Analizando el relato citado de manera crítica, nos animamos a afirmar que esta posición de “des-autorización propia" constituye una peligrosa contradicción que afecta a jóvenes y adultos: a los jóvenes, porque se mueven en un ambiente (la escuela) donde, de acuerdo al relato del preceptor, pareciera que la autoridad y el límite fuesen palabras prohibidas, y a los adultos, porque transitan por un lugar cada vez más frágil en términos de simbolización. Siguiendo esta línea, vale la pena recuperar un pasaje de Bleichmar: "en la escuela no somos todos iguales. Si fuéramos todos iguales, entonces sería imposible no solamente la instauración de las normas, sino también el aprendizaje: ¿por qué alguien tendría que aprender del otro que es un par?" (2008: 47).

Adentrándonos en la cuestión de la indiferencia de un modo más esquemático, pareciera que muchos adultos, incluso algunos educadores, prefieren posicionarse -por motivos ya descriptos- en el lugar de observadores; asumen que si un joven camina en dirección a una piedra es mejor que la embista, para que este aprenda de manera autónoma -y con una magulladura- que sería mejor esquivarla. Incluso cuando el adulto es consciente de los riesgos a los que el joven se expone, en el ejemplo mencionado el adulto decide privar al joven de la protección que, fundada en el bagaje cultural y en la diferencia intergeneracional, supone la intervención del adulto. Resumiendo podríamos decir que, cuando un adulto decide correrse de su lugar de autoridad, deja - y hasta promueve- que el joven "choque" directamente con un mundo que, siendo algo pesimistas, se revela excesivamente individualista y escasamente simbólico. Al respecto, como señala nuevamente Bleichmar: 
Si tuviéramos que aprender a vivir por ensayo y error, nos moriríamos al primer error. No se puede aprender a vivir por ensayo y error: no les metemos a los nenes los dedos en el enchufe para que sepan que la gente se muere por la descarga de corriente eléctrica. En cambio, les decimos: "no toques, porque te morís". Y el niño nos cree. No sabe bien qué es morirse, pero sabe que es perder el cariño del adulto. [...] Por lo tanto, no se aprende por ensayo y error, sino por confianza en el otro. Se aprende porque uno cree en la palabra del otro (2008: 32-33).

Cuando el adulto decide correrse deliberadamente de su lugar como portavoz y protector, comienzan a establecerse otros modos de relación. Esta reconfiguración se evidencia en la anulación de las líneas divisorias que históricamente han separado a los jóvenes de los adultos. Aquí consideramos pertinente citar el testimonio de una vicedirectora (correspondiente a la "escuela del centro") y el de un preceptor (correspondiente a la "escuela del barrio ferroviario"):

Hay una falta de compromiso de los padres. Yo la llamo "la escuela sin padres" porque lamentablemente los largan solos a los chicos y los chicos no están en una edad para largarse solos. Recién empiezan a vivir [...]. Lo que más necesitan los chicos es un diálogo en casa. Uno en la escuela les puede explicar mil veces las cosas, pero después cuando salen de acá tienen otro tipo de vida.

Hemos citado a padres de chicos problemáticos y no van nunca, o cuando van, van de mala gana. Cuando vos les decís lo que no les gusta escuchar, te agreden. Los padres por lo general no te respaldan, depositan a los hijos en la escuela y siempre les dan la razón a ellos.

Pareciera, por lo tanto, que hoy estamos en presencia de un proceso de identificación inverso al establecido en la modernidad. En línea con Corea y Lewkowicz (1999), hoy podríamos decir que muchos adultos intentan asemejarse cada vez más, en apariencia y en comportamiento, a los jóvenes. Esto no solo implica una reconfiguración en las relaciones que históricamente se establecieron entre unos y otros, sino que recrudece el encapsulamiento de los segundos. Los jóvenes no buscan respuestas en los mayores porque pareciera que estos no son capaces de proporcionar herramientas adecuadas para superar las dificultades por las que transitan.

\subsection{La incertidumbre respecto al futuro}

Muchas investigaciones dedicadas a la violencia en las escuelas identifican la incertidumbre respecto al futuro como uno de los principales agravantes de la problemática tratada (Corea y Duschatzky, 2001; Bleichmar, 2008; Castorina, 2008; Kornblit, 2008; 
Kaplan, 2009, entre otros). Dentro de esta categoría podrían incluirse dos procesos determinantes: el declive de las instituciones y la ruptura con la idea de progreso infinito.

En Civilización y violencia, Elias (1981) introduce la ausencia de futuro como uno de los principales detonantes de la violencia, y lo explica narrando un hecho histórico: tras la derrota de los soldados alemanes de la Primera Guerra Mundial, los miembros del ejército derrotado conformaron un Cuerpo de Voluntarios. Este movimiento -leal a un país que había dejado de existir del modo en que lo conocían al inicio de la guerra- se encontraba en una situación desesperada: la causa por la que estaban dispuestos a entregar su vida había desaparecido en manos de los enemigos y en manos de los propios alemanes, más específicamente, de aquellos que prefirieron rendirse. Sin país por el cual luchar, estos jóvenes autoconvocados -en torno a una causa debilitada- se encontraron estancados en una situación de profunda incertidumbre. En palabras del propio Elias:

En una situación así, los jóvenes necesitan básicamente por lo menos tres cosas [...]. Necesitan perspectivas de futuro; necesitan un grupo de personas de la misma edad [...], y, en tercer lugar, necesitan un ideal, una meta que dé sentido a su vida. Para la mayoría de los miembros del Cuerpo de Voluntarios, con el derrumbamiento de Alemania se había perdido exactamente eso que para ellos constituía el fin último, una tarea con sentido muy superior al de la propia vida (ibíd:: 147).

La situación de los hombres del Cuerpo de Voluntarios era desesperada: se trataba de un grupo de jóvenes dispuestos a luchar, pero no sin causa por la cual hacerlo. Es entonces que estos ex-soldados comenzaron a optar por alternativas más radicales; esto se hizo evidente cuando comenzaron a atentar contra los responsables del Tratado de Versalles. Empleando la violencia como recurso para manifestar su descontento, estos jóvenes -despojados de futuro- intentaron volcar sus frustraciones sobre aquellos que prefirieron deponer las armas y firmar el pacto.

De acuerdo al relato recién citado, la ausencia de porvenir, la incertidumbre y el "sinsentido", constituirían las causas que habrían conducido a estos jóvenes a materializar -mediante recursos comúnmente considerados violentos- su imposibilidad de previsión, de proyección, de anhelo, etcétera. Aquí la violencia representa un modo material, sencillo y eficaz de habitar el presente, de gozar la espontaneidad. De lo hasta aquí desarrollado podríamos deducir que, sin anclajes ni proyección de fututo, no sería necesario construir condiciones pacíficas de convivencia. Sin el reconocimiento mínimo de un orden 
simbólico, todo está permitido; dicho de otro modo, al no existir un reconocimiento consensuado del límite, la idea de trasgresión no tiene ningún significado.

Recordemos que, para Elías, el problema de la violencia no reside únicamente en las manifestaciones, sino en los modos en los que esta puede ser canalizada. En sus propias palabras: "hoy día, la investigación se concentra en aquellos que ejercen la violencia buscando una explicación de por qué lo hacen. Mi enfoque es, por el contrario, el siguiente: ¿cómo se puede entender que podamos convivir tan pacíficamente?” (1981: 142). Esto sugiere que la convivencia constituye un aprendizaje, un esfuerzo por aceptar al otro en el marco de un orden que excede las individualidades y garantiza que los esfuerzos por coexistir pacíficamente valen la pena, que serán retribuidos -al menos- con la edificación de un mejor porvenir. “¿Por qué cumplimos la ley? ¿Por qué aceptamos las normas? Porque sabemos que siempre perdemos algo a cambio de ganar algo" (Bleichmar: 2008: 36). Cuando el orden que reúne y mancomuna voluntades se desarticula, tal como ocurrió en la Alemania de posguerra, es muy probable que la confianza depositada en el futuro se vea resquebrajada y, consecuentemente, alterados los pactos de convivencia.

La renuncia al goce inmediato se sustenta en la perspectiva de futuro; tal como vimos con el ejemplo narrado por Elias (1981), la imposibilidad de proyectar un futuro conlleva un peligroso ascenso del presente y la inmediatez. Estas condiciones efímeras y espontáneas de habitar el ahora se erigen como un nuevo dogmatismo centrado en la convicción de que el presente es la única opción posible.

Con los pertinentes recaudos teóricos, la situación de muchos jóvenes argentinos en edad escolar también podría considerarse como una situación atravesada por una profunda incertidumbre:

En nuestro país una enorme cantidad de chicos no tienen claro cuál es su futuro o directamente no anhelan un futuro y viven en la inmediatez total. Y esto es lo que vemos reflejado en su imposibilidad de aprender. No está dado porque no sean inteligentes, está dado porque no creen que los conocimientos que reciban puedan servirles para enfrentar la vida. Se ven reducidos a la inmediatez de la vida que les ha tocado y nadie les propone soñar un país distinto desde una palabra autorizada (Bleichmar, 2008: 32).

La ausencia de una palabra autorizada que invite a edificar un porvenir sugiere que muchos jóvenes difícilmente puedan alcanzar ese nivel de preocupación por ellos mismos. Por el contrario, creemos que una de las principales metas de la educación debería ser "hacer sitio al que llega" (Meirieu, 1998: 81), o, en otros términos, introducir la preocupación por el 
futuro y crear las condiciones para que los jóvenes puedan adentrarse progresivamente al mundo con la posibilidad de llevar adelante sus propios proyectos. De acuerdo con Arendt: "mediante la educación decidimos si amamos a nuestros hijos lo bastante como para no arrojarlos de nuestro mundo y librarlos a sus propios recursos, ni quitarles de las manos la oportunidad de emprender algo nuevo" (1996: 208).

Un joven no puede plantearse a sí mismo que debe esforzarse por apropiarse de determinados saberes para construir un futuro; quizás suene algo básico, pero no está de más recalcar que estas intervenciones corresponden a las generaciones precedentes, así como les corresponde crear un escenario en el que esas promesas tengan sentido. Pineau nos recuerda que la educación siempre estuvo ligada al progreso, al futuro deseado, a una utopía accesible:

La utopía -el futuro soñado, imaginado, deseado- se ubica al fin del camino y se llega allí mediante la razón [...]. Este camino es posible de ser recorrido mejor mediante la educación. A partir de los planteos ilustrados, la educación, en su unión indisoluble con la razón, permite la construcción de este bienestar general, de este progreso, de estas utopías. Los fines educativos dejan de estar en la satisfacción inmediata de las necesidades o en la obtención de la otra vida, para ubicarse en el mejor futuro posible de ser construido por la humanidad (2008: 88).

Con la crisis de la modernidad en términos generales, y el debilitamiento simbólico y material de la escuela en términos algo más específicos, la fusión entre escuela y futuro que, históricamente, le confirió sentido de existencia a la primera, parece haberse replegado en favor del presente, del ahora, de lo efímero. Siguiendo a Kaplan: "los adolescentes y jóvenes se ven limitados objetivamente en la fabricación de una representación simbólica sobre su futuro. La falta de proyección a futuro atraviesa a todos los alumnos" (2009: 17).

El testimonio de una vice-directora (perteneciente a la "escuela de la periferia norte") también revela la preocupación por el futuro:

La persona que no tiene trabajo, que no tiene plata, que no tiene esto, que no tiene lo otro... eso también provoca [violencia]. Pero si tienen la posibilidad de hacer un curso ya hay otra cosa en la cabeza de ese joven, eso va a ayudar a que haya menos violencia. ${ }^{47}$

Con cierto pesimismo, Bleichmar concluye que "con su capital simbólico, este país sigue participando del mundo. Pero los niños han quedado excluidos de la adquisición de ese capital simbólico. Los padres los mandan a la escuela con muy poca confianza en el futuro" (2008: 41). En este contexto, uno de los desafíos que debe plantearse la escuela es

\footnotetext{
${ }^{47}$ El texto entre corchetes es propio.
} 
encontrar el modo en que los jóvenes puedan superar el presente más allá de su condición de origen; que puedan plantearse el reto de hacer algo más, algo nuevo, algo mejor.

\subsection{Conclusiones parciales}

El corrimiento del adulto justificado en la preservación de la autonomía del joven constituye un rasgo característico de nuestro tiempo, que repercute de manera directa en el problema de la violencia en las escuelas. La liberación del joven en favor de su independencia supone una ruptura con los valores que dieron forma a la modernidad, pero, al mismo tiempo, genera un vacío de autoridad que se completa con la ley del más fuerte. Bajo la premisa de preservar la autonomía de los jóvenes, hoy se han desdibujado las barreras intergeneracionales, obligando a los nuevos a construir su propio mundo al margen de la protección de una cultura.

En este escenario (acaso un poco apocalíptico) de desregulación generalizada, los jóvenes deben autogobernarse estableciendo sus propios códigos, sus propias leyes -en suma, su propio mundo. Esto los conduce a enfrentar una serie de riesgos: por un lado los provenientes del exterior, es decir, las consecuencias de chocar - de manera directa y sin cuidados- con una serie de cánones sociales organizados en torno a un ferviente individualismo; y por otro los inherentes al propio grupo, esto es, la lucha con los pares por establecer las relaciones de dominio. De acuerdo con Furlán, "la importancia de los pares en grupos cerrados es apenas consecuencia de aquel apartamiento que significa crecer en medio de la desolación" (2013: 16).

Centrando la atención en el autogobierno de los jóvenes y empleando algunas herramientas conceptuales inicialmente pensadas por Arendt, es posible trazar cierta analogía entre los modos en que los jóvenes se relacionan entre sí y ciertos esquemas tiránicos de dominación. En esta clase de estructuras se impone la ley del más fuerte y la igualación de los dominados por su condición de minoría o "inferioridad" (física, económica, nacionalidad de origen, elección de género, etcétera). Bajo un orden tiránico, el único modo de sobrevivir es a través de la obediencia y la sumisión, anulando de esta manera cualquier intento de manifestación singular. En este marco, la violencia, entendida como una manifestación con un fuerte contenido físico que se revela al margen de un orden simbólico, constituye un medio de relación, de imposición, de demanda. Frente a la 
decisión de la mayoría no hay modo alguno de rebelarse, porque el joven se encuentra atrapado entre dos mundos: el de los adultos, que aún se encuentra cerrado para él, y el de sus pares, al que debe subordinarse -y hasta humillarse- para sobrevivir (Arendt, 1996).

Frente a este panorama esquemático de jóvenes estableciendo sus propios códigos y adultos observando inermes, cabe preguntarse: ¿qué función cumplen hoy, desde un punto de vista simbólico, los docentes y las autoridades de una escuela secundaria? Como desarrollaremos en el cuarto capítulo, hallamos que muchos de los profesionales entrevistados se manifestaron "atrapados" en una rutina, o, en sus propios términos, en una "vorágine" que les dificulta atender cuestiones vinculadas con la convivencia escolar.

En un contexto sociopolítico en el que la docencia muestra claros síntomas de desprestigio social y desvalorización material, la preocupación de muchos educadores por mejorar sus situaciones personales (en términos económicos) es llevada a cabo, en ocasiones, en detrimento de algunos requerimientos "extraoficiales" dispuestos para tratar asuntos vinculados a la convivencia escolar (reuniones, charlas, capacitaciones, etcétera); de acuerdo con el testimonio de un preceptor (perteneciente a la "escuela del barrio ferroviario"), "para cambiar algo hay que aportar tiempo de cada uno, y, sobre todo, ganas. [...] De esa manera vamos a poder acordar criterios para trabajar la violencia”. Debido, en gran parte, a la ya descripta situación socio-económica que atraviesa -simbólica y materialmente- la profesión docente, el modo en que muchos profesionales de la educación han resuelto esta doble demanda (entre los requerimientos de la escuela y el cubrimiento de las propias necesidades básicas) ha sido, de acuerdo al propio relato de algunos docentes, a través de la indiferencia.

Siendo algo pesimistas, creemos que esta práctica de la docencia apresurada, efímera, "errante" en términos de Duschatzky (2007), altera un poco el significado de la autoridad escolar para los estudiantes. Esto puede constatarse, por ejemplo, en la desconfianza que manifestó uno de los grupos de alumnos entrevistados (en la "escuela del centro"), cuando afirmaron que los intentos de los docentes y las autoridades por resolver los conflictos que interpelan a los alumnos, "no sirven para nada".

En este marco interpretativo pareciera que, en términos generales, los adultos no tienen -o no saben cómo hallar- respuestas a los problemas que deben enfrentar los jóvenes en edad escolar. Este desencuentro hace que muchos jóvenes consideren el grupo de pares 
como el primer referente, asignándole un valor primordial al presente, a la inmediatez y, atendiendo las advertencias de Elias (1981), a la violencia. 


\section{Capítulo 3: El debilitamiento del lenguaje}

La concepción del yo en nuestra existencia conduce, conforme a la concepción utilitarista del hombre que la secunda, a realizar cada vez al hombre como individuo, es decir, en un aislamiento del alma cada vez más emparentado con su abandono original.

Jacques Lacan (2010).

\subsection{El repliegue de la palabra}

Tras haber recorrido uno de los componentes centrales de la hipótesis, por el cual se presupone que las reconfiguraciones en los roles tradicionales de autoridad repercuten de manera directa sobre el problema -común y erróneamente- denominado "violencia escolar", consideramos pertinente ahora desarrollar el segundo eje analítico incluido en la conjetura inicial: el debilitamiento del lenguaje. Como premisa ordenadora es preciso aclarar que, de las múltiples lecturas y enfoques que pueden realizarse en torno a la cuestión del lenguaje, en este apartado se revisarán únicamente aquellas que se ajustan a su función simbólica y a su potencial como alternativa al uso de la fuerza física. La potencia que caracteriza al lenguaje supone que, contrariamente a lo que Arendt denomina la "violencia muda", la palabra se erige como una salida fundada en el reconocimiento del otro y en la posibilidad de simbolización.

En La condición humana Arendt afirma que "la pura violencia es muda" (2014: 40), focalizando su análisis en uno de los rasgos fundamentales de la violencia, esto es, actuar sin el uso de la palabra. En tanto que la palabra desprovista de un quién se reduce a "mera charla", es decir, a un conjunto de palabras que "no revelan nada" (ibíd.: 204), el puro acto es seducido por la simplicidad de la violencia. En términos de la autora: "si no hubiera nada más en juego que el uso de la acción como medio para alcanzar un fin, está claro que el mismo fin podría alcanzarse mucho más fácilmente en muda violencia" (Arendt, ibíd.: 203). A pesar de que la palabra constituye una alternativa pacífica a la acción violenta, pareciera que actualmente este recurso no cuenta con la eficacia necesaria para enfrentar la violencia de un modo efectivo; en otro texto, escrito a mediados del siglo XX, la autora sentencia que, "la propia palabra está ensombrecida por la controversia y la confusión" (Arendt, 1996: 101). 
Para varios de los antecedentes relevados en materia de violencia en las escuelas, las posibles manifestaciones de este fenómeno tienen, en algún punto, cierta conexión con la ausencia, la falencia, o lo que aquí se designa como el debilitamiento del lenguaje, esto es, la imposibilidad de hacer un uso persuasivo de la palabra para resolver conflictos de diversa naturaleza. Para Kaplan, por ejemplo, la violencia que se ve en las escuelas opera como un sustituto de la palabra, y, aunque considera que el conflicto es inherente a las relaciones humanas, la imposibilidad de canalizarlo por otros medios pone en jaque la estabilidad de las normas, afectando considerablemente la convivencia hacia el interior de las instituciones: ${ }^{48}$

Es preciso tener en cuenta que siempre habrá conflicto ya que es inherente a las relaciones sociales en las sociedades divididas; el tema, en todo caso, está en cómo abordarlo. Sostenemos a partir de nuestra indagación, que la violencia opera en lugar de la palabra (Kaplan, 2015: 20).

Muchos docentes, autoridades y miembros de Equipos de Orientación escolar de las escuelas seleccionadas advierten, en términos generales, un proceso de debilitamiento del lenguaje; al mismo tiempo, caracterizan la potencia de este recurso como un elemento fundamental para atenuar las manifestaciones violentas. En sus propios términos:

Acá parecería que no saben resolver las cosas con las palabras y los hechos son más contundentes, entonces necesitan descargar enseguida con sus manos (vicedirectora, "escuela del centro").

Y no hablan, no hablan. El profesor los quiere hacer hablar pero no encuentra el modo (preceptora, "escuela de la periferia norte").

Antes de hablar ya se agarraron a trompadas, eso es muy básico y genera una situación de violencia (vicedirectora, "escuela de la periferia norte").

Una de las constantes que pueden advertirse en los diálogos seleccionados es el repliegue del lenguaje y la sustitución de este recurso por otros comúnmente asociados a la violencia. Frases como "no saben resolver las cosas con las palabras", "no hablan" o "no usan la palabra", suelen estar sucedidas por alguna acción exteriorizada en el plano físico,

\footnotetext{
${ }^{48}$ En la definición de violencias escolares que propone Di Leo también se hace referencia al debilitamiento del lenguaje como uno de los elementos constitutivos del problema en cuestión. En sus propios términos: "los diversos sentidos y/o dimensiones de las violencias escolares [...] pueden ser abordados como múltiples expresiones de la crisis actual en los lazos sociales y de la precariedad en las mediaciones discursivas y simbólicas de los sujetos para reconocerse con relación a los otros, manifestando su necesidad primaria de afirmar sus propias identidades en contraposición a las de los demás" (2008: 18). Desde esta perspectiva, la irrupción de la violencia en la institución educativa no se trata de una serie de manifestaciones aisladas, sino que -en línea con la mayoría de los investigadores sociales abocados a esta temática- vincula el problema de la violencia con los procesos de des-civilización, identificando el enfrentamiento físico y la desconsideración del otro como las cuestiones más preocupantes a la hora de sostener una sociedad democrática.
} 
tal como "agarrarse a trompadas" o "descargar con las manos". Lejos de tratarse de un asunto menor, esta tendencia a emplear el cuerpo reducido a lo "físico" revela un preocupante acortamiento en la distancia que, siguiendo a Lacan (2010), debería existir en todo proceso de socialización entre la representación y la materialización de las conductas agresivas (castración, mutilación, desmembramiento, dislocación, destripamiento, devoración, etcétera).

Bajo la denominación de "diálogo", "palabra", "habla" o "conversación", los testimonios seleccionados a continuación reafirman la función del lenguaje como recurso tendiente a la no-violencia:

Los enfrentamientos y los desencuentros se deberían poder resolver por vía del diálogo. Cuando esa vía de diálogo no existe y se pasa a otro tipo de enfrentamiento, entonces ahí aparece la violencia (directora, "escuela del barrio ferroviario").

Yo creo que el hecho puntual para poder abordar la violencia dentro de la escuela es la palabra. [...] En el peor de los casos vos podés tener un alumno desbordado y demás, pero cuando haya un minuto de calma le tenés que hablar. Yo creo que es la única herramienta, si uno intenta callar a ese joven que está enojado, lo que lográs, es más violencia. [...] El tema es hablar y hablar (integrante de un Equipo de Orientación Escolar, "escuela de la periferia norte").

Hay que tratar de descubrir qué es lo que paso, qué es lo que está pasando que a través del diálogo no se puede resolver. Hay que confiar en un cien por ciento que hay que conversar, charlar, esclarecer, y aunque muchas veces no nos vamos a poner de acuerdo, no tenemos que pegarnos, ni tenemos que engendrar situaciones de violencia porque no estemos de acuerdo (vicedirectora, "escuela de la periferia norte").

Por el contrario, de más de treinta alumnos entrevistados, solo una alumna hizo referencia al lenguaje como alternativa pacífica a la violencia. Ante la pregunta: ¿cómo creen que podrían disminuir los niveles de violencia?, la joven mencionada respondió: "hablando con la persona que es violenta". También es pertinente señalar que las respuestas brindadas por los alumnos en las entrevistas grupales mostraron niveles muy básicos de locución. En general, las respuestas fueron de carácter monosilábico, evidenciando una seria dificultad para describir acontecimientos o expresar opiniones personales.

\subsection{Entre el cuerpo y el lenguaje}

El relevamiento de bibliografía especializada nos ha permitido detectar que una gran parte de los estudios referidos la violencia en las escuelas introduce la cuestión del cuerpo como un asunto determinante en la problemática tratada (Duschatzky y Corea, 2013; Di Leo, 2008; Furlán, 2013; Kaplan, 2008; Kornblit, 2008; Le Breton, 2017; Noel, 2006). En 
términos generales, el cuerpo aparece vinculado a la materialización, la exteriorización, la liberación de impulsos, como si se tratarse un objeto tangible o maleable sobre el que los jóvenes pueden plasmar aquello que no pueden manifestar mediante el empleo de recursos simbólicos. En esta lógica, el cuerpo pareciera recluirse al plano de lo físico, lo biológico, lo esencial.

Siguiendo esta línea, el cuerpo podría considerarse como un espacio de resguardo en la vida de los jóvenes, ocupando un lugar primordial: todo lo que no pasa por la palabra, pasa por la carne. El cuerpo escindido del lenguaje opera sencillamente como una materia viva a la espera de un estímulo para devolver una respuesta de forma automática. Sin la mediación de la palabra, la carne y la piel funcionan como depósitos materiales, tangibles y maleables de aquello que los jóvenes no pueden exteriorizar de otro modo: al sentimiento de culpa le corresponde un corte, al de ira un golpe, al enamoramiento un tatuaje, etcétera. Siguiendo a Furlán. "el cuerpo pasa a ser lo único que le queda al sujeto para poder afirmar su particularidad y ejercer su poder" (2013: 16).

Al no poder expresarse a través del lenguaje -por no encontrar o no reconocer espacios propicios para el diálogo-, el joven se encuentra aislado, no solo en términos simbólicos sino en términos físicos. "El joven ha perdido su centro, es arrojado a un mundo que no entiende y no logra separar sus fantasías de la realidad" (Le Breton, 2017: 42). La propia piel se convierte entonces en un espacio de seguridad y expresión, al mismo tiempo que representa el lugar en el cual depositar las frustraciones, las humillaciones, las tristezas, los duelos, el enojo, la ira, la decepción, etcétera. De acuerdo con Duschatzky y Corea, "la violencia [...] asume distintas formas, pero todas suponen una práctica situada en los bordes de la palabra. Se trata de una expresión que se materializa en el cuerpo" (2013: 2526).

Los usos del cuerpo que los jóvenes consultados manifestaron en las entrevistas grupales demostraron la permanencia de una serie de problemas vinculados en algún punto a la imposibilidad de hacer un uso persuasivo de la palabra, y con el desconocimiento -o la desconsideración- de las instancias mediadoras convencionales (en el marco de una escuela). El "conflicto", la "pelea", los “celos", el “castigo", la "venganza", todo es materializado en el plano físico; la palabra es reemplazada por la "trompada", la "patada" o la "cachetada" y el pasaje automático al acto pareciera erigirse como la forma más rápida y 
eficiente de alcanzar un objetivo o demandar algo. En términos de los propios entrevistados:

Una vez una chica se me hacía la re mala, era re zorra y me miraba re mal. Le gustaba hacer quilombo, entonces le puse la traba, cayó para atrás y se rompió la jeta (alumna, "escuela del barrio ferroviario").

Si te querés pelear le decís: “¿qué me mirás corte piola? ¡Vení a pelear, vení!” O le decís: “¿sos piola vos?”, "los piolas se cortan” y pum pum pum... O le decís en la cara: “iqué mirás?" Y ¡pum! (alumna, "escuela de la periferia norte").

A principio de año Sandra le tiró una silla a Nahuel porque le tenía envidia, porque él se hacía el cheto (alumno, "escuela del centro").

En los testimonios seleccionados puede apreciarse una tendencia a actuar inmediata e impulsivamente, anteponiendo el cuerpo -vivenciado como un instrumento listo para devolver una respuesta mecánica- en lugar de emplear otros recursos más ligados a la simbolización, es decir, al uso persuasivo de la palabra.

En este punto es preciso recordar que, si bien algunos eventos transcendentales, tales como las amenazas con armas o las agresiones físicas, son unánimemente catalogados como violentos, en muchas ocasiones los agentes escolares adultos anteponen el adjetivo de "violento" a algunas manifestaciones que, en la vida cotidiana de los alumnos -por influencia del barrio, de la familia, de las "juntas", etcétera- no son percibidas como tal. Inversamente, algunos estudiantes utilizan la subjetividad que envuelve a la violencia a su favor, tal como advierte Noel: "como a los ojos de los docentes no está siempre clara la distinción entre pelea y juego, los alumnos [...] en ocasiones logran persuadirlos de que «sólo están jugando» cuando entre ellos están de acuerdo en que están peleando" (2006: 40). El autor advierte que muchos profesionales de la educación, posicionándose desde un “deber ser" -propio de las escuelas pensadas originalmente para las clases medias-, suelen catalogar de "violentas" a determinadas conductas, desatendiendo los condicionantes sociales y los usos del cuerpo que "los sectores incluidos recientemente" traen consigo (ibíd.). Con algunos recaudos en relación a los prejuicios de clase, siguiendo esta línea interpretativa podría decirse que la escuela - por medio de una batería de dispositivos disciplinares- creó ciertas expectativas sobre los usos correctos del cuerpo, o, en términos de Di Leo, "una corporalidad canónica de los agentes del sistema escolar socializados en sectores medios" (2008: 24). A medida que el sistema educativo fue expandiéndose hacia

\footnotetext{
${ }^{49}$ Los nombres originales fueron modificados para preservar la identidad de los informantes.
} 
sectores históricamente desatendidos, muchas de las demandas sobre las "formas", las "maneras" o los "modales" encontraron resistencias provenientes de las diferencias entre la "clase social" de los educadores y la de los nuevos destinatarios. ${ }^{50}$ Desde nuestra perspectiva, la implicancia del cuerpo en los asuntos comúnmente caracterizados como violentos no tiene que ver únicamente con las diferencias de clase o con las exigencias históricas del sistema educativo, sino más bien con nuevas formas de experimentar el cuerpo que, más allá de las diferencias sociales, merecen ser atendidas debido a la inmediatez de las acciones (lo que, en términos lacanianos, se conoce como "el pasaje al acto”). En Una pedagogía para prevenir la violencia en la enseñanza, Meirieu se refiere a este fenómeno del siguiente modo:

En la actualidad la crisis mayor es la del pasaje sistemático al acto. Los alumnos de hace veinte o treinta años eran quizás mentalmente tan violentos como los de hoy, pero no pasaban al acto. El pasaje al acto es lo que me parece problemático, ya que es un pasaje a la violencia, a veces en términos de agresión física (2007: 3).

Al mismo tiempo que el joven se aísla cada vez más sobre sí mismo -producto de vivir a espaldas de los adultos y bajo el dominio de sus semejantes- el lenguaje comienza a debilitarse, a retraerse, a modificarse; se diluye la posibilidad de simbolizar y comienzan a evidenciarse unos usos del cuerpo de carácter impulsivo, reaccionario, volátil. ${ }^{51}$

En El cuerpo herido, Le Breton denomina estas acciones emplazadas al margen del lenguaje como "conductas de riesgo" (2017: 37). Con esta denominación, el autor se refiriere a una serie de comportamientos evidenciables en las nuevas generaciones (de adolescentes franceses), en los que se advierte un uso del cuerpo asociado a la expresión de emociones y a la experimentación del peligro (intentando alcanzar, y exhibir, el límite más cercano a la muerte que el cuerpo pueda tolerar). En sus términos:

El rasgo común de estas conductas juveniles consiste en la exposición deliberada al riesgo de lesionarse o de morir, de alterar su porvenir personal o de poner su salud en peligro: desafíos, juegos peligrosos, intentos de suicido, escapadas, vagabundeos, embriaguez, toxicomanías, trastornos alimenticios, velocidad en las rutas, violencia, delincuencia,

\footnotetext{
${ }^{50}$ Un ejemplo recurrente en lo que refiere a las expectativas de los agentes escolares adultos (sobre todo de aquellos provenientes de sectores medios), suele evidenciarse en los requerimientos de indumentaria. Mientras que para los educadores la imagen de alumno ideal suele estar asociada al guardapolvo o al uniforme, la indumentaria que frecuentemente usan los estudiantes de barrios marginados gira en torno al uso de ropa deportiva.

${ }^{51}$ Es preciso aclarar que, en el contexto de la presente investigación, la noción de impulso no tiene nada que ver con la idea de instinto o con cualquier comportamiento supuestamente implícito desde el nacimiento; por el contrario, creemos que esta construcción esconde una peligrosa conexión con los esencialismos. El carácter impulsivo de una acción radica, más bien, en la irreflexión y en la imposibilidad de anticipar las consecuencias de la misma.
} 
incivilidad [...]. La acción es una tentativa psíquicamente económica de escapar a la impotencia (2017: 37-38).

Cabe aclarar que estas conductas representan un riesgo desde la mirada del observador externo, pero no para los propios jóvenes. A pesar de que estos puedan identificar perfectamente el peligro al cual se enfrentan y las probables consecuencias, la acción desprovista de lenguaje transgrede cualquier idea de preservación. Con la aceptación del reto también se acepta el riego que este conlleva: cuanto más peligro, mejor. En un mundo donde se premian el individualismo y la autosuperación, el desafío de superar el límite establecido por otro o de hacer algo nuevo que ponga en riesgo la propia vida constituye una parte fundamental de estas nuevas modalidades de "vivenciar" o de "sentir" el cuerpo. Según Le Breton, "la propensión a la acción que caracteriza a esa edad se vincula con la dificultad de poner en movimiento dentro suyo recursos de sentido para enfrentar los escollos biográficos de otro modo" (ibíd.).

Frente a la imposibilidad de construir una identidad propia y de pertenecer a un mundo en el que deberían ser cuidados por los mayores, muchos jóvenes encuentran en la estimulación del cuerpo un medio para existir. "A lo inasible de sí mismo y del mundo [el adolescente] le opone lo concreto del cuerpo" (Le Breton, ibíd.: 46). ${ }^{52}$ La constante e ilimitada búsqueda de sensaciones constituye una forma de habitar el presente: ¿para qué esforzarse en construir vínculos y dirimir diferencias por medio de recursos simbólicos si la violencia permite materializar el deseo de una manera mucho más sencilla y eficaz? Si solo queda habitar el ahora (como parecen entender algunos jóvenes), y ahora lo único que poseo es un cuerpo, ponerlo en riesgo es un modo de sentir que estoy vivo, que soy capaz de sentir, de experimentar, de alcanzar algo a lo que no logro acceder por otra vía.

La herida, el tatuaje, el piercing, los implantes, pueden considerarse marcas o rasgos identitarios de generaciones que no pueden inscribirse en un orden simbólico, esto es, expresar con palabras aquello que sienten. "La imposibilidad de salir de la situación por medio del lenguaje obliga a pasar por el cuerpo [...] como un intento desesperado por mantenerse en el mundo, por encontrar de dónde agarrarse" (Le Breton, 2017: 58). Pero esta imposibilidad no es producto de una rebelión juvenil generalizada que se propone desplazar el habla tal cual la conocemos, sino una consecuencia histórica ligada al egoísmo,

\footnotetext{
${ }^{52}$ El texto entre corchetes es propio.
} 
al individualismo y a la experimentación del cuerpo en su sentido puramente físico y orgánico. Siguiendo los aportes de Kornblit:

El bajo control de las emociones y la vía libre a las experiencias agresivas son el correlato [...] de la imposibilidad de poner en palabras el malestar, originado en múltiples falencias de la estructura, amén de las dificultades personales. Como tantas veces se ha dicho, la cultura de la imagen y el descrédito del trabajo intelectual favorecen la expresión directa de las emociones, sin la mediación de la palabra y la reflexión (2008: 11).

Partiendo de las reflexiones de Le Breton (2017), las acciones incluidas dentro de las conductas de riesgo representan un peligro, en primer orden, para el propio cuerpo (al someterlo a situaciones de las que se puede resultar herido), y en segundo, para el cuerpo del otro (ya que las acciones violentas tendientes a ocasionar un daño tienen como objetivo final la invalidación o el aniquilamiento). Desde la perspectiva de un contendiente preparado para una pelea -siempre y cuando no sea en defensa propia o esté en riesgo la propia vida-, el otro es reducido a la categoría de objeto, algo que, sencillamente, sería mejor quitar del camino. ${ }^{53}$ Lejos de tratarse de un asunto menor, estos usos del cuerpo ligados a lo que en determinado contexto puede considerarse "violencia", revelan una seria dificultad para vivir en relación con otros.

En un acto considerado "violento" se pone en juego, por lo general, no solo la integridad física (tanto la propia como la del adversario), sino también "la dificultad del joven para encontrar sus referencias en relación a los demás" (Le Breton, 2017: 48). En las escuelas estudiadas no solo se evidenciaron serios problemas a la hora de emplear la palabra como recurso tendiente a la negociación, sino también en el reconocimiento de instancias mediadoras, es decir, en la identificación de espacios previstos para dirimir los conflictos de una manera democrática.

En las sociedades complejas, explica Kaplan, el uso argumentado de la palabra debería superar la fuerza muscular:

\footnotetext{
${ }^{53}$ El uso de la violencia en defensa propia es un tema muy controversial ya que confronta el derecho a la vida con la justificación de la violencia. Si bien es imposible establecer una generalización en este punto, ya que cada caso se compone de elementos únicos, consideramos pertinente atender al modo en que Arendt intenta resolverlo: "la violencia puede ser justificable pero nunca será legítima. Su justificación pierde plausibilidad cuanto más se aleja en el futuro el fin propuesto. Nadie discute el uso de la violencia en defensa propia porque el peligro no sólo resulta claro sino que es actual y el fin que justifica los medios es inmediato" (Arendt, 2006: 72). La autora citada "solucionó" el problema de la violencia en defensa propia apelando a la necesidad e inmediatez del acto. En esta línea de análisis, la violencia en defensa propia posee justificación relativa, cuando se trata de una reacción instantánea frente al riesgo de ser herido o perder la vida. En contraposición, la violencia perpetuada a lo largo del tiempo, por ejemplo la aplicada sistemáticamente por un gobierno, no podría contar con ninguna legitimación, puesto que no solo no hay riesgo que amerite su uso, sino que además su empleo constituye una estrategia -sistemática y racional- de dominio.
} 
Las sociedades más complejas han asumido como instrumento principal de disputa la argumentación, la persuasión a través de la palabra, prescindiendo de la fuerza física y de la violencia para la solución de conflictos. Las fuerzas de la oratoria y del discurso bien estructurado superan la fuerza muscular. La amenaza física al individuo lentamente pierde su personalidad, pues se queda sujeta al control del estado, un control más riguroso, calculable y predecible (2013: 116).

El reconocimiento de un orden superior constituido por normas tendientes a la convivencia, la aceptación de la autoridad y los usos responsables del cuerpo, requiere una serie de aprendizajes fundamentales para la vida en sociedad. Dado que estas demandas provienen siempre del exterior, en tanto exigencias tendientes a la represión del narcisismo, estas demandas van a ser inicialmente resistidas. Abandonar ese estado de egoísmo inicial implica un esfuerzo y un arduo trabajo por parte de los dos polos involucrados: en un extremo se encuentra el niño, que se resiste a salir de su mundo interior, y en el otro se halla el adulto, quien pretende desarticular su mundo para introducirlo en otro donde operan las leyes de una cultura determinada. En el apartado siguiente revisaremos algunos fragmentos de El malestar en la cultura, donde el propio Freud se refiere a la tensión que resulta de una cultura que pretende asentarse sobre los deseos egoístas y las manifestaciones violentas de sus miembros.

\subsection{Violencia, represión y cultura}

Desde los primeros momentos posteriores al nacimiento, el niño pequeño no distingue su yo del mundo exterior y su nexo con el afuera se acota al pecho materno. Cuando este le es sustraído temporariamente, el lactante consigue recuperarlo mediante el llanto. "De este modo se contrapone por primera vez al yo un «objeto» como algo que se encuentra «afuera» y sólo mediante una acción particular es esforzado a aparecer” (Freud, 1992b: 68). A partir de este momento, y sobre la base de diversos estímulos externos, el niño comenzará progresivamente a "desasir el yo de la masa de sensaciones, vale decir, a reconocer un «afuera», un mundo exterior" (Freud, ibíd.). Estos afluentes exteriores propiciarán, de manera frecuente, diversas sensaciones de dolor y displacer que colisionarán inevitablemente con el principio de placer. $^{54}$

\footnotetext{
${ }^{54}$ En pocas palabras, el principio de placer tiene como rasgo fundamental evitar el displacer y perpetuar las satisfacciones directas del yo. "Este principio gobierna la operación del aparato anímico desde el comienzo mismo (...) y su programa entra en querella con el mundo entero" (Freud, 1992b: 76). Cabe aclarar que por su naturaleza extremadamente narcisista, este principio es irrealizable e ilícito, recluyéndose en consecuencia al terreno de las fantasías.
} 
Nace la tendencia a segregar del yo todo lo que pueda devenir fuente de un tal displacer, a arrojarlo hacia afuera, a formar un puro yo-placer, al que se contrapone un ahí-afuera ajeno, amenazador [...]. Así se aprende un procedimiento que [...] permite distinguir lo interno -lo perteneciente al yo- y lo externo -lo que proviene de un mundo exterior(Freud, ibid:: 68).

A partir de esta distinción entre un yo-placer y un afuera-amenaza comienza a instaurarse, progresivamente, el principio de realidad: una fuerza externa que obstaculiza la plena realización del yo. La experimentación del placer solo puede concebirse en relación a un contraste, es decir, al displacer o la desdicha. Frente a la imposibilidad de sostener un placer egoísta y al mismo tiempo vivir en comunidad, Freud identifica la subordinación de la dicha individual a la de todos, como un paso elemental en la conformación de una cultura. Este desplazamiento de la vida pulsional al gobierno implica un doble movimiento: la sumisión del yo y la construcción de una defensa (asociada a las instancias psíquicas más elevadas). Dicho de otro modo: al disminuir el placer de las satisfacciones inhibidas, se alcanzaría cierta protección del sufrimiento devenido por su insatisfacción. De acuerdo a Sierra y Wankiewicz, "el sujeto renuncia a la satisfacción de sus pulsiones a cambio de la seguridad y protección que le brinda la inserción en la cultura, regulada por leyes que ponen un coto a la satisfacción pulsional directa" (2016: 39). En otras palabras, teniendo en cuenta que el disgusto de las pulsiones no inhibidas es más doloroso, la protección ofrecida por subordinarse a la vida en comunidad proveería cierto mecanismo de defensa para hacer frente a las frustraciones. Entre los "recursos culturales" implementados para mitigar el sufrimiento, Freud menciona el desplazamiento libidinal hacia ocupaciones profesionales y artísticas. Estas producciones, en tanto se mantengan alejadas de la obligación, reflejarían cierta "producción más fina y superior" (Freud, 1992b: 79) que las mociones pulsionales, a las que califica de "groseras".

Entre las actividades reprimidas por el principio de realidad se destacan la violencia y el ejercicio libre de la sexualidad como dos de las principales acciones a ser procesadas y ordenadas por los intereses de una comunidad. En el caso de la violencia, el goce asociado al uso de la fuerza para alcanzar un objetivo es censurado mediante leyes, al mismo tiempo que es reprimido por un juicio moral colectivo, evidenciable en los límites -variables- de la tolerancia. De ser necesario, los intereses de una comunidad, defendidos por la censura, serán sostenidos por medio de una violencia aún mayor. Bajo el clásico lema violencia a la violencia, "la cultura espera prevenir los excesos más groseros de la fuerza bruta 
arrogándose el derecho de ejercer ella misma una violencia sobre los criminales" (Freud, 1992b: 109). Lejos de que este proceso de sumisión del placer se trate de una transferencia armónica, Freud la caracteriza como un malestar. Como dicen Sierra y Wankiewicz, "la cultura edificada de este modo no permite la libre tramitación de las pulsiones, generando un malestar que surge de este inevitable desencuentro entre lo pulsional y la cultura" (2016: 39).

Una vez instituida, los miembros de una comunidad deben renunciar al ejercicio de la violencia para satisfacer sus demandas individuales; este recurso debe reposar en manos de la fuerza pública y su uso será legítimo en tanto sea aplicado en favor de la defensa del territorio y el aseguramiento del orden público. ${ }^{55}$ Solo el estado puede hacer uso legítimo de la violencia; el uso independiente y deliberado de la misma es considerado un atentado contra el equilibrio de la sociedad, y por esto mismo se establecen un conjunto de leyes que castigan su empleo y convierten el acto en ilegítimo. "Una historia implacablemente realista muestra que la violencia se halla en el origen mismo del poder del estado, que es inseparable de él" (Aranguren, 1973: 144).

Siguiendo a Freud (1992b), para que una comunidad pueda lograr cierta estabilidad en su funcionamiento debe existir una regulación de los vínculos personales. Si las leyes no son aceptadas por todos, entonces aquellos que decidan vivir de acuerdo a sus propias leyes deberán asumir los riesgos de una exposición aislada al sufrimiento y la frustración.

De faltar ese intento [de regular los lazos sociales], tales vínculos quedarían sometidos a la arbitrariedad del individuo, vale decir, el de mayor fuerza física los resolvería en el sentido de sus intereses y mociones pulsionales. Y nada cambiaría si este individuo se topara con otro aún más fuerte que él. La convivencia humana sólo se vuelve posible cuando se aglutina una mayoría más fuerte que los individuos aislados, y cohesionada frente a estos. Ahora el poder de esta comunidad se contrapone, como «derecho», al poder del individuo, que es condenado como «violencia bruta» (ibíd.: 93). ${ }^{56}$

\footnotetext{
${ }^{55} \mathrm{Si}$ bien el estado, a través del derecho, considera que la violencia en manos de la persona aislada constituye un peligro o una amenaza para el orden social, esto cambia cuando la violencia es impartida por "fuerzas legítimas" tales como la milicia o la policía; el aseguramiento del status quo constituye argumento suficiente para emplear la fuerza cuando esta sea requerida por un gobierno. Atendiendo a Benjamin: "la violencia, cuando no se halla en posesión del derecho (...), representa para éste una amenaza, no a causa de los fines que la violencia persigue, sino por su simple existencia fuera del derecho" (1995: 32). La legitimidad de la violencia se construye entonces en el movimiento que va del afuera hacia el adentro del derecho, o, dicho de otro modo, el estado hace propia la violencia amparándose en el mantenimiento de un orden social y creando organismos para su monopolio. Para Benjamin, esta relación entre el derecho y la violencia no es neutral; por el contrario, se presta a una serie de confusiones y ambigüedades que acaban por revestir a la violencia de cierta "legalidad" no para resguardar el orden, sino como un mecanismo de gobierno.

${ }^{56} \mathrm{El}$ texto entre corchetes es propio.
} 
A modo de síntesis, podríamos decir que el concepto de violencia bruta remite, desde la perspectiva de Freud, a una instancia física, primitiva, natural y narcisista, mientras que la cultura constituye el paso "evolutivo" necesario para procesarla a través de la sublimación. Lejos de tratarse de una teoría en desuso, esta concepción se sostiene hasta nuestros días, sobre todo en el campo de la educación, donde se supone que la realización de determinadas actividades, sobre todo las artísticas o las comúnmente denominadas físicas (en el sentido en que demandan un gasto de energía calórico), conducirán a los impulsos “a dirigirse por otros caminos" (Freud, ibíd:: 93). ${ }^{57}$

\subsection{La potencia del lenguaje}

Esta breve revisión de algunas teorías freudianas asociadas al establecimiento de la cultura y el aplacamiento de la violencia nos sirven como punto de partida para el análisis de lo que sucede en el conflictivo pasaje de lo individual a lo social, del narcisismo al reconocimiento del otro, del egoísmo a la solidaridad, del sometimiento a la negociación. Muchos autores dedicados al estudio de la violencia en las escuelas hacen mención a este callejón que hoy aparenta no tener una meta clara: pareciera que la resolución de las conductas egoístas en comportamientos sociales fuera un antiguo adagio que remite a otros tiempos.

Sobre este tránsito a la vida en comunidad, Lacan (2010) aporta un conjunto de hipótesis en las que propone reelaborar la tópica freudiana haciendo hincapié en la función constitutiva de la agresividad y en el reconocimiento de un orden simbólico. Para el psicoanalista francés, el problema de la propuesta freudiana es que parte del supuesto de que todos los humanos son agresivos, dificultando la construcción de cualquier hipótesis que trascienda esa afirmación. Esto constituye una contradicción, ya que no se puede analizar algo que se asume como dogmático e incuestionable; esta interpretación conlleva, desde su perspectiva, los caracteres de una aporía: ${ }^{58}$

\footnotetext{
${ }^{57}$ Para que las pulsiones egoístas puedan rendirse a los mandatos sociales, es preciso que actúen factores externos, tal como ocurre con la educación. Para Freud, esta es "portadora de las exigencias del medio cultural (...). La cultura se adquiere por renuncia a la satisfacción pulsional, y a cada recién venido le exige esa misma renuncia" (1992b: 284). La educación, desde la perspectiva freudiana, tiene un sentido netamente instrumental: esta es sinónimo de represión y de sublimación de los deseos egoístas.

${ }^{58}$ Lacan se despega de los postulados freudianos que vinculan la agresividad casi automáticamente con la pulsión de muerte. El psicoanalista francés se pronuncia en contra de cierta naturaleza agresiva común a la especie humana, advirtiendo la permanencia de una serie de contradicciones que deberían ponerse en cuestionamiento. "La agresividad que el sujeto experimentará aquí no tiene nada que ver con la agresividad animal del deseo frustrado" (Lacan, 2010: 243). En esta línea, también es importante aclarar que Lacan toma
} 
Si se designa por instintos a conductas atávicas cuya violencia hubo de hacer necesaria la ley de la selva primitiva, [...] bien podemos preguntarnos por qué, desde que el hombre es hombre, no se revelan también impulsos de excavar, de plantar, de cocinar y hasta de enterrar a los muertos (Lacan, 2010: 148-149).

Antes de adentrarnos la concepción lacaniana de agresividad, consideramos preciso repasar brevemente algunas de sus reflexiones ligadas al registro simbólico. Dado que el ser humano no se rige por comportamientos instintivos, sino que es capaz de desplazarlos en favor de una construcción que va más allá de lo animal, de lo puramente biológico, podemos hablar de la posibilidad una representación simbólica consensuada. En sus propios términos, "cuando uno de esos segmentos desplazados adquiere un valor socializado, sirve de referencia para determinado comportamiento colectivo" (Lacan, 1953: 9). Un hombre no necesariamente va a reclamar tener relaciones sexuales con una mujer de acuerdo a su ciclo menstrual; este puede no sentir atracción hacia las mujeres o, inclusive, dirigir su deseo sexual hacia objetos inanimados.

El simbolismo se establece por una interpretación interhumana de la realidad, se trata de "lo que encontramos, y aquello de lo que hablamos, es lo que encontramos y volvemos a encontrar sin cesar" (Lacan, 1953: 11). Su funcionamiento se basa en símbolos organizados en el lenguaje que se ponen en marcha a partir de "la articulación del significante y el significado" (Lacan, ibíd.). ${ }^{59}$ Aun sin tener noción de cuándo ni cómo ha comenzado, el lenguaje está ahí, no tenemos chance de saber cómo era la vida antes de que emergiera. El lenguaje no solo designa algo, cumple una función estructurante; no sirve únicamente para nombrar los miembros de un grupo, también determina el modo en que

distancia de Freud respecto al destino de la agresividad. Según Evans, para Freud "la agresividad es una manifestación dirigida hacia afuera" (Evans, 2007: 32); para Lacan (2010), en cambio, la agresividad puede estar dirigida tanto hacia el exterior como hacia el propio cuerpo.

${ }^{59}$ Es preciso recordar que Lacan desarrolla una relectura psicoanalítica de las teorías lingüísticas de Saussure en la que invierte el lugar del significado y el significante y propone un nuevo algoritmo: ubica el significante por encima del significado en una relación de tipo contingente en vez de arbitraria, intentando romper con el paralelismo de la propuesta original, y otorgando mayor importancia al lugar del significante. En el algoritmo lacaniano, significante (S) y significado (s) no se enmarcan bajo una esfera de dominio cerrado, como ocurría con la representación del signo saussureano. Otra diferencia se halla en la línea divisoria: mientras que para Saussure esta línea representa una relación positiva, para Lacan simboliza la separación de dos órdenes diferentes. El resultado de esta relación no es un arbitrio del significante limitado por una serie de significados preestablecidos por consenso, sino que "el significante se desliga de la operación de dominio que sobre él ejerce la lingüística" (Carabajal, D’Angelo y Marchilli, 2012: 24). Resumidamente, esto quiere decir que, desde la óptica de Lacan, las palabras pueden no representar lo que comúnmente significan, o, en otros términos, su significado depende del significante. Ahora bien, para que se produzca una significación es preciso una articulación entre, al menos, dos significantes, esto quiere decir que un significante por sí solo no puede crear un significado. Dicho de otro modo, un significante no representa un significado, este solo se define en la relación con otro significante. 
tales miembros se constituyen como sujetos. "El lenguaje, innegablemente, ocupa un lugar central en el universo simbólico; y más específicamente, las palabras hacen al mundo social al distinguirlo" (Kaplan, 2009: 21).

Lacan relee de manera crítica la experiencia freudiana sobre la violencia y la cultura, introduciendo el valor constitutivo de la palabra como uno de los aspectos fundamentales en la reconstrucción de dichas categorías. Aquí se destacan dos movimientos con respecto a la propuesta freudiana: en primer lugar, la violencia no es un fenómeno común; no es la manifestación de un "lado salvaje", ni tampoco es aplacable por vía de la civilización. La segunda cuestión radica en que, si bien la violencia posee una connotación destructiva, la agresividad -cuando es acompañada de represión- posee un carácter constitutivo: los límites de la agresividad son experimentados en un movimiento dialéctico fundamental para la formación del sujeto.

Teniendo en cuenta estas aclaraciones, nos adentraremos en dos elementos desarrollados por Lacan en La agresividad en psicoanálisis: la agresividad y el lenguaje. Creemos que una revisión de estos conceptos desde el punto de vista lacaniano puede servirnos para entender mejor el fenómeno de la violencia en las escuelas y esbozar -teóricamente- algunos modos posibles de sosegarla.

Lacan plantea que la agresividad nos es dada como "intención de agresión", escenificándose como anticipo, preludio del acto agresivo. Es sólo intención aunque puede incluir al acto [...]. Ésta puede manifestarse a través de la palabra y de imágenes (Sierra y Wankiewicz, 2016: 42).

El pasaje de la agresión manifiesta a la representación simbólica suele ser, en términos lacanianos, el modo más frecuente de procesar la agresividad. Cuando la intención de conseguir algo, provocar o dañar no es sublimada en una fantasía y el protagonista del acto no es capaz de esconder sus intenciones -sino que, por el contrario, desearía magnificarlas desatendiendo las consecuencias de sus actos-, nos encontramos frente a "la violencia propiamente dicha" (Lacan, 2010). La diferencia con la agresión reside en la efectivización de la intención. Mientras que la agresión es generalmente sublimada en imágenes, fantasías, insultos, autoflagelos, etcétera, el acto violento -en tanto manifestación contraria a la palabra- va por todo, no reconoce límites en su exteriorización. ${ }^{60}$ Este tipo de acto es

\footnotetext{
${ }^{60}$ En pocas palabras, podría decirse que la violencia en perspectiva lacaniana es la efectivización magnificada de la intención. Se trata de una manifestación menos frecuente que la agresión y más grave en cuanto a las consecuencias. Debido a su carácter destructivo, la violencia rompe las barreras culturales y trasciende toda
} 
menos frecuente que la agresión. ${ }^{61}$ La diferenciación que hace Gallo entre agresividad y violencia nos puede ayudar a entender mejor las características fundamentales de cada uno de estos conceptos:

Lo contrario de la palabra es un acto que resulta violento cuando tiene la particularidad de no comportar un llamado al Otro de la ley, al Otro marcado por el significante, al Otro que en tanto lugar de la palabra autoriza y funda un sistema de relaciones simbólicas. El acto violento, es aquel que en rigor no comporta un mensaje, por ejemplo, de decepción, malestar, ira, vértigo, injuria, desprecio, ni expresa un deseo, por ejemplo de muerte como sí puede suceder con la agresividad en el plano imaginario (2016: 59).

La agresión -en tanto manifestación de agresividad- no implica necesariamente una sustancia; el acto violento sí. El enojo de una madre con su hijo por no obedecerle no implica automáticamente una cachetada, ella puede reprimirlo o exteriorizarlo de múltiples maneras. Estas imágenes o manifestaciones son formas de agresión, y en tanto conformen un proceso posterior de elaboración positiva, constituirán el fenómeno de la agresividad. "La agresividad no excluye ese elemento objeto de intercambio -la palabra- mediante el cual nos reconocemos, mientras que en la violencia deja de circular como elemento que permite la constitución del símbolo" (Gallo, ibíd.: 64).

Para desarrollar mejor este concepto, Lacan sustituye las pulsiones del psicoanálisis freudiano y en su lugar introduce la noción de imago. Con este movimiento reconoce la agresividad como una de las funciones formadoras en el sujeto. "Un padre severo intimida por su sola presencia y la imagen del Castigador apenas necesita enarbolarse para que el niño la forme" (2010: 110). Estas representaciones mentales -imagos para Lacan- son determinantes en la constitución de la personalidad, pero no por tratarse de cualidades innatas sino de imágenes estructurantes.

Volviendo al análisis de la agresividad, es preciso señalar que las intenciones agresivas suelen estar vinculadas con las imagos del cuerpo fragmentado, es decir, con las representaciones previas al estadio del espejo:

posibilidad de intercambio o reconocimiento del otro, mientras que la agresividad "puede ser simbolizada y captada en el mecanismo de lo que es represión, inconsciencia, de lo que es analizable e incluso, digámoslo de forma general, latente en la relación imaginaria" (Lacan, 1999: 468). Sobre el concepto de violencia en Lacan, Héctor Gallo, en Del bullying o matoneo, aporta lo siguiente: "la impostura del agente de la violencia, consistirá en ocupar el lugar de alguien que en vez de llevar a cabo acciones simbólicas (...), opta por una irrupción en lo simbólico de algo real, desarticulado de la estructura de la palabra" (2016: 60).

${ }^{61}$ La idea de que la violencia es un acto menos recurrente que la agresión también puede deducirse a partir de un breve fragmento incluido en Subversión del sujeto y dialéctica del deseo en el inconsciente freudiano, donde Lacan expresa: "el pacto es siempre previo a la violencia (...), y lo que llamamos lo simbólico domina lo imaginario” (Lacan, 2009: 771). 
Son las imágenes de castración, de mutilación, de desmembramiento, de dislocación, de destripamiento, de devoración, de reventamiento del cuerpo, en una palabra, las imagos que personalmente he agrupado bajo la rúbrica que bien parece ser estructural de imagos del cuerpo fragmentado (Lacan, ibíd:: 110). ${ }^{62}$

La agresión como mecanismo reaccionario no es una estrategia innata que revela el estado de indefensión absoluta de un niño, no se trata de la reacción instintiva de un animal acorralado por su cazador, sino que es parte de un proceso de adaptación al mundo social, esto es, el pasaje de tomar y arrebatar lo deseado al empleo articulado e intencionado del lenguaje para la negociación.

Dado que el niño debe adaptarse a las decisiones de los adultos para sobrevivir, la intención de agresión (materializada, por ejemplo, en la rotura de objetos) puede representar la frustración del sometimiento. Siguiendo esta línea, el papel del niño en los juegos de rol -representando al tirano y al verdugo- puede simbolizar el castigo recibido por sus padres. De acuerdo al pensamiento lacaniano, cuando este rompe los juguetes, daña el entorno, golpea o muerde -y es reprimido por un adulto-, experimenta los límites de la agresividad. Para que el pasaje de la agresión a la negociación pueda llevarse a cabo, es necesaria la intervención de un portavoz de las normas establecidas para la vida en sociedad. El adulto -en tanto representante de imágenes pacificadoras- es quien debe establecer esos límites (en la verbalización del acto, en la explicitación de disconformidad, en el castigo, etcétera).

En un primer momento, es muy poco probable que el niño acepte pacíficamente deponer el uso de la fuerza y buscar un acuerdo por vía del lenguaje. La agresividad conlleva resistencias y oposiciones: el yo que relata una acción -el hijo que debe explicar a sus padres por qué le pegó a su hermana, el alumno que debe explicar a su maestra por qué rompió el cuaderno de su compañero- debe enfrentarse a la posibilidad de una reprimenda, un acto que excede incluso a quien debe juzgar la acción.

Los juegos con el propio cuerpo y el cuerpo de los demás también sirven para conocer los límites de la agresividad: los niños suelen revestir el cuerpo de prácticas censuradas por los padres y por otros adultos. Junto con la masturbación, el desnudo, el autoflagelo y la satisfacción de algunas necesidades fisiológicas, la agresividad que

\footnotetext{
${ }^{62}$ Resumidamente, la noción de cuerpo fragmentado representa una amenaza a la fantasía de integridad que constituye el yo. Según Evans: "el cuerpo fragmentado no designa solo las imágenes del cuerpo físico, sino también cualquier sensación de fragmentación y de falta de unidad. Cualquiera de estas sensaciones de falta de unidad amenaza la ilusión de síntesis que constituye el yo" (2007: 60).
} 
inicialmente es tolerada bajo la imagen de juego infantil, progresivamente es sometida a la represión. No obstante, esto no significa que la relación con el propio cuerpo -incómoda para la mirada del adulto- fácilmente se someta a las normativas culturales; se trata de un arduo proceso dialéctico plagado de resistencias. ${ }^{63}$

Explorando la potencia del lenguaje como factor mitigador de la violencia, consideramos preciso centrar la mirada en el ingreso al orden simbólico y la consecuente renuncia al uso de la fuerza. En este sentido, Lacan afirma que "el diálogo parece en sí mismo constituir una renuncia a la agresividad" (2006: 111), y para justificarlo remite a la vía racional pensada por Sócrates como “esperanza de diálogo” (ibíd.). Más adelante, en su conferencia Lo simbólico, lo imaginario y lo real, Lacan dirá que "la palabra juega ese papel esencial de mediación. De mediación, es decir de algo que cambia a los dos partenaires en presencia" (1953: 17). Gallo, por su parte, resume esta cualidad pacificadora de la palabra del siguiente modo: "la violencia es lo contrario de la palabra, [...] desaloja la intención en donde todavía hay posibilidad de hablar" (2016: 58).

Los romanos ya habían reparado en la potencia del lenguaje cuando empleaban la persuasión como medio de dominación y gobierno. Esta alternativa al uso de la fuerza parte del principio básico de que los objetivos perseguidos por una guerra pueden lograrse por medios considerablemente más económicos, es decir, a través de un uso racional e intencionado de la palabra. Esta confianza en la potencia del lenguaje como factor constitutivo de los lazos sociales es advertible en numerosos autores provenientes de diversos campos.

En el pensamiento de Arendt (2014), por ejemplo, el poder depende del consenso, es decir, de la disponibilidad conjunta a actuar a través el acto y la palabra. A partir del análisis de algunas experiencias desarrolladas en la polis griega, la autora considera que la persuasión es capaz de reemplazar el uso de la violencia, trasladando la atención del campo de batalla al mundo de la política. No obstante, esta ruptura del sometimiento a la espada no

\footnotetext{
${ }^{63}$ Lacan (2010) desmiente la idea de que en las sociedades avanzadas o civilizadas el cuerpo del adulto no es producto de flagelos. En este sentido, los tatuajes, las incisiones o la moda (como el uso de corsets, la perforación de la piel y la realización de cirugías cosméticas) en cierta medida constituyen formas "más legítimas" de moldear el cuerpo. Para el psicoanalista francés no existe algo así como una forma natural del cuerpo humano que admita la agresión, y una forma avanzada -o civilizada- que la reprima totalmente. En esta posición Lacan se separa considerablemente de Freud, puesto que el segundo asociaba la idea de agresión -y muy posiblemente también la violencia- a cierta manifestación primitiva o pre-cultural, la cual podría mitigarse mediante el proceso civilizatorio propio de las sociedades modernas.
} 
implica el abandono absoluto de la violencia; esta es reservada para los que se hallan fuera de la polis, y, dentro de la misma, para quienes intenten trasgredir las normas. Desde su punto de vista,

Ser político, vivir en una polis, significaba que todo se decía por medio de palabras y de persuasión, y no con la fuerza y la violencia. Para el modo de pensar griego, obligar a las personas por medio de la violencia, mandar en vez de persuadir, eran formas prepolíticas para tratar con la gente cuya existencia estaba al margen de la polis (Arendt 2014: 40).

Centrando la atención en los conflictos globales de comienzos del siglo XXI, y atendiendo a las reflexiones lacanianas, Žižek también destaca la importancia del lenguaje para la comunicación y la intersubjetividad. El filósofo resalta su valor como "medio de reconciliación y mediación, o de la coexistencia pacífica" (Žižek, 2008: 78). La introducción de un orden simbólico depone la necesidad de apelar a un medio violento o a una confrontación inmediata. Siguiendo esta línea de análisis, incluso la agresión verbal o el insulto suponen un reconocimiento -al menos mínimo- del otro, como un sujeto atravesado por el lenguaje (trasladando a un segundo plano la necesidad de apelar a la confrontación física):

En el lenguaje, en vez de ejercer violencia directa sobre el otro queremos debatir, intercambiar palabras, y tal intercambio, incluso cuando es agresivo, presupone un reconocimiento mínimo de la otra parte. La entrada en el lenguaje y la renuncia a la violencia son a menudo entendidas como dos aspectos de un mismo gesto (Žižek, ibíd.).

\subsection{La constitución del orden simbólico}

Con cierto matiz propositivo, creemos que las teorías lacanianas centradas en la agresividad y el lenguaje nos permiten comprender $-\mathrm{y}$ recalcar- la función pacificadora del orden simbólico. Adentrándonos poco a poco en este ejercicio, es decir, en la exploración de alternativas simbólicas tendientes a la no-violencia, consideramos pertinente desarrollar tres ejes, los cuales hemos denominado: la reelaboración positiva del conflicto, la rearticulación cuerpo-lenguaje, y el reconocimiento de la ley.

\subsection{1) La reelaboración positiva del conflicto}

Desde un punto de vista educativo-tradicional, o, para ser más específicos, previo a la sanción de la Ley 26.206 de Educación Nacional, ${ }^{64}$ un conflicto considerado "violento" por

\footnotetext{
${ }^{64} \mathrm{Si}$ bien la sanción de la ley mencionada no es argumento suficiente para hablar de un cambio "radical" de posiciones a la hora de tratar un asunto considerado violento en el marco de una escuela -de hecho así lo
} 
los agentes escolares adultos era considerado -y arbitrariamente señalado- como una falta, una trasgresión, una ruptura deliberada del orden establecido. Desde este enfoque -hoy considerado ineficaz y antirreglamentario-, la manera más frecuente de proceder solía ser la aplicación de un castigo individual con una fuerte connotación punitiva, culpabilizando exclusivamente al protagonista del acto y desatendiendo sus posibles causas (Kaplan, 2009). En esta lógica, el alumno señalado culpable debía ser apartado para su reencauzamiento: se lo sancionaba con alguna clase de medida "correctiva", se lo suspendía o, de acuerdo a la gravedad del asunto, se lo expulsaba. En este marco disciplinar, el ejecutante del acto "violento" carga sobre sus espaldas, al menos, dos problemas: el que lo condujo inicialmente a utilizar la fuerza y el que le sucede como consecuencia a su accionar. Aquí pareciera que no hay momento para la reflexión, para desenmarañar por qué un joven decide trasgredir las barreras de la tolerancia, ni (lo más preocupante) para introducir alternativas pacíficas para la resolución de conflictos.

Este modo convencional de resolver los conflictos "violentos" descuida la posibilidad -y la oportunidad- de reordenar los lazos sociales garantizando el derecho a la educación. Además, al no promover una reelaboración positiva del conflicto, la apelación a la violencia puede ser interpretada como un problema propio, individual, arraigándolo aún más en la personalidad. Teniendo en cuenta que los alumnos de una escuela se encuentran en formación, consideramos que sería más enriquecedor introducir un "elemento constitutivo" que excluirlos sin posibilidad alguna de resignificación. Con Lacan (2010) es posible pensar que, si bien la violencia debe ser señalada como una acción inapropiada para vivir en sociedad, su reelaboración, la reflexión sobre sus consecuencias y la búsqueda de alternativas simbólicas son medidas que pueden colaborar en su mitigación. En esta misma línea Meirieu afirma que "la violencia, la prohibición de la violencia, no se discute sino que se descubre" (2007: 5). Con el acento puesto en la potencia del lenguaje y la proyección hacia el futuro, debemos asumir que sin la intervención de un portavoz de la cultura, el pasaje del acto violento a la representación simbólica nunca será llevado a cabo.

hemos corroborado en la presente investigación-, creemos que su contenido ofrece algunas herramientas para encarar este tipo de problemas desde una perspectiva considerablemente más democrática, esto es, "garantizando el derecho a la educación" y promoviendo -al menos en el marco normativo-, la "convivencia escolar", un "adecuado clima de estudio" y el "respeto por la autoridad de los/as docentes y los/as profesores/as" (Ley 26.206/06 de Educación Nacional). 
La palabra puede ser fuente de conflictos y ello es justamente lo productivo. La riqueza del diálogo está en la diferencia, pero hay que poder aceptar que el punto de vista del otro no es más que "eso": un punto de vista, y que tiene el mismo valor que el propio, o que quizá pueda enriquecer el propio punto de vista (Boggino, en: Kornblit, 2008: 36).

La tarea de introducir el lenguaje allí donde este no se evidencia es una labor ardua y minuciosa que no puede llevarse a cabo con mecanismos coactivos (tales como la represión, el castigo o la censura). Combatir la violencia con más violencia solo alimentará un ciclo inagotable de rencor y venganza que tarde o temprano conducirá al estallido de un nuevo conflicto, con consecuencias cada vez más graves. En contraposición, y atendiendo los aportes de Meirieu (2007), consideramos que la violencia debe ser "metabolizada" o "reelaborada" de manera positiva, asumiendo que las diferencias van a existir siempre pero que estas no pueden exteriorizarse de un modo destructivo.

En relación al proceso de elaboración positiva de la violencia, consideramos oportuno citar una intervención del pedagogo polaco Janusz Korczak, relatada por Meirieu:

Él había fundado orfelinatos en Varsovia y trataba de acompañar a chicos que estaban en situaciones sumamente difíciles: se peleaban todo el tiempo por la comida, la supervivencia, porque cada uno quería acaparar al maestro para sí. Este educador buscó dispositivos para luchar contra la violencia de estos chicos entre sí, y con respecto a los maestros. [...] Un día les dijo a los chicos: "A partir de hoy, todos tienen derecho a pegarle al que sea, pero avisándole por escrito 24 horas antes". Entonces instaló en el orfanato una "caja de pelea" donde los chicos tenían derecho a escribir por qué querían pegarle a otro. [...]. Este pensador había apostado a que les decía que tenían derecho a la expresión, pero no con violencia, sino por otra vía. De este modo él planteó un acto pedagógico que para mí es fundante de una pedagogía contra la violencia, puesto que permite ponerle límite al acto de violencia en el que están muchos alumnos, siempre y cuando ese pasaje no se viva como la prohibición de expresarse (2007: 5).

En este ejemplo es posible rastrear la introducción del lenguaje -por escrito y argumentado- como salida posible al problema de la confrontación física. Lo relevante de esta alternativa es que el educador citado en el relato no parte de una reprimenda ni reclama obediencia, ya que es consciente de que los dispositivos convencionales resultan insuficientes. En cambio, el maestro en cuestión realizó una intervención más compleja, a través de la cual se mantiene -y se alienta- el lugar del joven como un sujeto con demandas y necesidades. En otras palabras, Korczak reconoce la presencia de una serie de problemas propios del contexto en el que se encuentra, al mismo tiempo que entiende la necesidad de los jóvenes de exteriorizar sus descontentos. La “caja de pelea" representa la exteriorización de dos dificultades: el malestar de vivir en un contexto violento y la posibilidad de expresar ese descontento de una manera simbólica. Creemos que la 
conclusión de Meirieu es pertinente y certera: "lo que funda una sociedad es el esfuerzo para no utilizar la violencia" (ibíd.: 4).

\subsection{2) La rearticulación cuerpo-lenguaje}

Como vimos más arriba en la descripción de las conductas de riesgo caracterizadas por Le Breton (2017), la manera en que muchos jóvenes suelen manifestar sus problemas y sus emociones revela la presencia de una relación "violenta" con el propio cuerpo y con el cuerpo de los demás, depositando en la piel y la carne aquello que no pueden exteriorizar de otro modo. Según Crisorio (2015), esta "fisicalización" de las emociones remite a la experiencia de habitar un cuerpo reducido a lo puramente físico, biológico y esencial, ${ }^{65}$ esto es, un conjunto de órganos funcionando prácticamente por estímulo y respuesta. Este modo de "sentir" o "experimentar" el cuerpo constituye una catapulta a la acción, o, en términos arendtianos, un modo de actuar escindido de la palabra (Arendt, 2014). Habitar un cuerpo disociado del lenguaje es el equivalente a vivir en un estado de automatización: todo se reduce a un conjunto de órganos a la espera de una provocación capaz de desatar una reacción mecánica. Para el caso de la violencia, la escisión cuerpo-lenguaje revela la inexistencia de un plano simbólico, entre el estímulo y la respuesta.

Como vimos con Lacan (2010), la introducción de "lo simbólico" solo puede llevarse a cabo mediante la intervención de un tercero. Lo mismo sucede con los usos responsables del cuerpo: la relación de un joven con su cuerpo no puede construirse al margen de la cultura. "Lejos de pertenecer a la naturaleza, el cuerpo es de la cultura y tiene una historia en la que hay que indagar" (Crisorio, 2009: 170). ${ }^{66}$ Siguiendo esta línea de análisis, un ser humano al margen del orden simbólico sería tan solo un conjunto de órganos funcionando por automatismos, es decir, reaccionando de forma instantánea ante

\footnotetext{
${ }^{65}$ Esta supuesta naturaleza del cuerpo, asociada a un origen esencial, supone también un modo único de interpretar el cuerpo, de estudiarlo, de tomarlo por objeto, considerándolo como "perteneciente a la naturaleza en cuanto universo, (...) fundamental, constante, como si tuviera un modo de ser que le es propio y que hay que conocer tal como efectiva y naturalmente es" (Crisorio 2014: 168). Es preciso destacar que la reflexión de Crisorio no niega el cuerpo sustancial que la fisiología toma por objeto, más bien lo traslada a una dimensión socio-política mucho más amplia y diversificada.

${ }^{66}$ Resumidamente, podría decirse que Crisorio introduce lo que podría considerarse un "giro" en los modos de interpretar el cuerpo. Desde una perspectiva alternativa al clásico reduccionismo orgánico, propone que "el saber del cuerpo en tanto algo distinto del organismo, requiere investigaciones por entero distintas de las de la fisiología, la neurología o la psicología. Requiere indagar, por ejemplo, precisamente cómo, y si fuera posible por qué, en nuestra cultura el cuerpo ha devenido unidad orgánica, dado que hay pruebas suficientes de que no siempre lo fue" (2011: 6).
} 
determinados estímulos. Cuando las exteriorizaciones físicas de la agresividad no son reprimidas o, en términos lacanianos, cuando las imagos del cuerpo fragmentado (la castración, la mutilación, el desmembramiento, la dislocación, el destripamiento, la devoración, el reventamiento) desbordan el registro imaginario, es muy posible que la relación de un joven con su cuerpo y el cuerpo de los demás se constituya al margen de la simbolización y el reconocimiento de los límites establecidos en una cultura.

Ya hemos revisado varias teorías enfocadas en los procesos civilizatorios provenientes de diversos campos-, en las que se menciona la misma necesidad: para la constitución y el funcionamiento de una cultura es preciso deponer la fuerza y emplear el lenguaje como común denominador. Sin esta restricción, la irrupción de la violencia es perfectamente admisible, ya que este medio representa el modo más eficaz de satisfacer las necesidades de un cuerpo vivido únicamente en su faz biológica. Tanto si nos posicionamos desde estas perspectivas como si volvemos la atención hacia los jóvenes que asisten a las escuelas seleccionadas, estamos en condiciones de sostener que, tanto la confrontación física directa como el empleo de insultos, amenazas y provocaciones, revelan un profundo debilitamiento del lenguaje como medio de intercambio y negociación. Inversamente, el cuerpo es experimentado o vivido como un lienzo sobre el que es posible plasmar las dificultades propias de transitar una juventud descuidada por los adultos y gobernada por los pares. Bajo estas circunstancias, la violencia puede ser considerada, sencillamente, como una manera habitual de experimentar un cuerpo escindido del lenguaje. La contrapartida, el desafío o la exigencia, en términos de Meirieu (2007), consiste en anteponer la representación sobre la acción, introduciendo la argumentación y el uso responsable del cuerpo en lugar del individualismo y el pasaje automático al acto. De acuerdo con Southwell, "gran parte de la tarea que le toca a la escuela consiste en ampliar las oportunidades para construir respeto, reconocimiento y cuidado hacia el otro" (2018: 8).

\subsection{3) El reconocimiento de la ley}

A diferencia de Freud (1992b), quien (siendo muy esquemáticos) entiende la agresividad como una manifestación derivada de ciertas pulsiones originarias o primitivas, Lacan (2010) articula el análisis de la agresividad con el valor constitutivo de la experiencia, más específicamente, con la función del registro imaginario en la constitución del yo. De 
acuerdo con Sierra y Wankiewicz, "en la lógica imaginaria no hay lugar para dos, o es uno o es otro, por lo que se desencadena la agresividad propia de esta dimensión ante la posible amenaza de fragmentación y evidencia de la carencia" (2016: 43); dicho de otro modo, dado que el egoísmo narcisista no puede sostenerse en la realidad, la agresividad es frecuentemente desviada al registro imaginario. Pero, para que esto suceda -es decir, para que la agresión repose en una intención de agresión-, debe existir una instancia de represión. En el pensamiento lacaniano, esta función es desarrollada, generalmente, por la función del padre, ${ }^{67}$ quien, en tanto se posicione como un portavoz de la cultura, representa las demandas del mundo exterior y las manifiesta en el proceso comúnmente denominado complejo de castración (tema en el que no ahondaremos). Es preciso aclarar que este proceso dialéctico y represivo no significa que la agresividad sea exteriorizada únicamente en la niñez, por el contrario se encuentra siempre presente en el comportamiento humano y se manifiesta con mayor intensidad en momentos trascendentales (como el pasaje a la adultez o la maternidad). Si bien la represión y la simbolización constituyen en cierta medida una renuncia la "agresividad física", de acuerdo con Lacan (2010) esta nunca desaparece: se trata una conducta -basada en la experimentación del odio y el amorpresente a lo largo de toda la vida.

El desarrollo de una agresividad "formativa" o, en términos más precisos, constitutiva del yo, es una experiencia dialéctica que resulta del estar -e interactuar- con otros. Pero, cabe señalar, esta experiencia puede ser reelaborada positivamente solo si existe una estructura social e institucional capaz de acompañar este proceso. La escuela históricamente representó la primera institución -fuera de la esfera privada- donde esos límites fueron transmitidos. Siguiendo a Meirieu: "la escuela es un lugar donde los chicos tienen que descubrir la ley, no construir la ley [...]. La ley permite discutir pero no es discutible [...]. La suspensión de la violencia no es discutible" (2007: 4).

Los límites que una sociedad establece sobre el accionar de sus miembros, entonces, deberían constituir un margen de acción en el que sus integrantes deberían reconocer fronteras y prohibiciones. Sin la presencia del límite no hay posibilidad de establecer una

\footnotetext{
${ }^{67}$ En la conferencia publicada bajo el título La familia, Lacan atribuye al padre dos papeles fundamentales: "el padre representa la autoridad y es el centro de la revelación sexual" (Lacan, 2003: 47). De acuerdo a esta doble función -protectora y prohibitiva-, a medida que el niño comienza a reconocer los límites de la cultura, este debería proscribir sus deseos sobre el progenitor de sexo opuesto y acatar, con ciertas resistencias, las represiones comúnmente vinculadas a la sexualidad.
} 
línea divisoria entre la tolerancia y la trasgresión, entre lo admitido y lo prohibido, entre lo aceptable y lo indeseado. ${ }^{68}$ En la "autorregulación juvenil", aunque los límites puedan ser reconocidos $-\mathrm{y}$ hasta expresados verbalmente en un ejercicio de simulación-, pareciera que su efectividad se ha debilitado. La irrelevancia de las normas -por omisión o desconsideración- pone de manifiesto cierta imposibilidad de los jóvenes por reconocerse a sí mismos, a sus pares y a los mayores como integrantes de algo más grande que los mancomuna. ${ }^{69}$ Siguiendo a Duschatzky y Corea:

Cuando la ley simbólica -en tanto límite y posibilidad- no opera, el semejante no se configura. El semejante no es una construcción espontánea que nace del vínculo entre dos sujetos. El semejante es siempre igual a otro, ante y mediante un tercero. Es la ley la que, a partir de instituir un principio de legalidad basado en la formulación de la igualdad, habilita la construcción de un semejante. De aquí se deriva que si la ley no opera como principio de interpelación, tampoco opera la percepción de su trasgresión (2013: 25).

La independencia respecto de la ley no representa, necesariamente, una liberación en términos positivos; la autonomía también conlleva cierto riesgo a padecer en soledad (Freud, 1992b). Podría decirse que un joven autónomo, emancipado o independiente, además de adentrarse en el mundo para poder sobrevivir, deberá hacerlo de manera improvisada, desprovisto de guía. La vida en relación con otros y el acatamiento de una ley

\footnotetext{
${ }^{68}$ En una investigación llevada a cabo por Litichever centrada en los reglamentos de convivencia de varias escuelas medias de Argentina, se destaca que el contenido de estos documentos, además de sostener ciertas costumbres comúnmente asociadas a la escuela (vestimenta, puntualidad, pautas de respeto, conductas aprobadas y censuradas, etc.), también incluyen -sobre todo en estos últimos años- nuevas normas vinculadas con lo que podría denominarse "problemáticas contemporáneas". Según la autora, "la incorporación de nuevas normas da cuenta de una transformación al interior de la escuela media, particularmente, en relación con los cambios a nivel de las fronteras entre lo prohibido y lo permitido y de los parámetros aceptados por el imaginario social" (2012: 8). Siguiendo esta línea, podría decirse que la separación entre lo debido y lo indebido ya no se establece únicamente a partir de lo que acontece en el interior de la institución educativa (como si se tratase de un lugar aislado), sino que estas distinciones - plasmadas generalmente en los Acuerdos Institucionales de Convivencia y en otros reglamentos de la misma naturaleza- revelan cierta permeabilidad en relación a las dificultades y los acontecimientos que históricamente estuvieron situados "al margen" de la escuela.

${ }^{69}$ Sobre la ley entendida como una exterioridad capaz de mediar en los conflictos particulares, resulta pertinente atender a las reflexiones de Kessler, quien, a partir de una investigación desarrollada en cuatro escuelas comúnmente catalogadas como violentas, advierte: "había algo que era transversal a toda la investigación y era la dificultad que tenían los jóvenes para percibir la existencia de la ley. Le ley entendida como una terceridad, una institución o una persona, que legítimamente podía intervenir en los conflictos privados. (...) Tal dilución de toda instancia facultada para intervenir en los conflictos privados llevaba al punto que se desdibujaba la idea misma del Estado" (2006: 18). Desde nuestra perspectiva, consideramos preciso recalcar que no son únicamente los estudiantes quienes muestran conflictos con la percepción de la ley; muchos docentes y directivos también evidencian malentendidos en este punto. En ocasiones, a la hora de identificar los eventos comúnmente considerados violentos y aplicar las normativas institucionales previstas, muchos profesionales consultados han reconocido que prefieren -probablemente por ignorancia o desconsideración- aplicar sus propias reglas (añadiendo un considerable, y debatible, conjunto de arbitrariedades y valoraciones personales). Este tema será ampliado en el capítulo siguiente.
} 
común, si bien constituyen un sacrificio en términos narcisistas, también proveen cierta protección a la hora de "metabolizar" los fracasos y las decepciones.

Si bien muchos de los documentos destinados a la resolución de conflictos intentan dirimir las diferencias de un modo democrático y asegurando la permanencia del alumno en el sistema educativo -en cierta forma los Acuerdos Institucionales de Convivencia operan bajo esta lógica-, la ley penal no repara en estos cuidados. ${ }^{70}$ Es por este motivo que consideramos que la liberación de los jóvenes a sus propios recursos representa un peligro considerable para ellos. No es un dato menor el hecho de que el poder judicial -en respuesta a la demanda de un importante sector de la sociedad argentina- pretenda, en contra de numerosos tratados internacionales, establecer penas más duras a chicos cada vez más chicos.

\subsection{Conclusiones parciales}

Tras la revisión del primer componente de la hipótesis, enfocado en la reconfiguración de la autoridad, en este capítulo se hizo hincapié en el segundo de los factores posiblemente desencadenantes y agravantes de las manifestaciones comúnmente interpretadas como "violentas" en contextos escolares: el debilitamiento del lenguaje. Después de analizar la opinión de varios informantes y de revisar un volumen considerable de bibliografía especializada, nos atrevemos a afirmar que la simbolización es una práctica que revela claros signos de debilitamiento. Ampliando esta afirmación, y centrando la atención en el análisis de las entrevistas realizadas a los alumnos, podemos agregar que, frente a la dificultad de manifestase en el plano simbólico y de hallar -y reconocer- un espacio de

\footnotetext{
${ }^{70}$ En términos generales, los Acuerdos Institucionales de Convivencia suelen descansar en un plano metateórico, y se asientan sobre la construcción de un ideal de alumno capaz de entender y hacer un uso democrático de la ley, comprometido con la institución educativa e idóneo en la resolución de diversas problemáticas (las cuales, en ocasiones, exceden la jurisdicción escolar). Una de las guías distribuidas por la Provincia de Buenos Aires para el tratamiento de situaciones conflictivas establece, como acción para la promoción de la convivencia: "abordar la temática de las violencias y las formas dialogadas de resolución de conflictos en las diferentes instancias institucionales y comunitarias. Para ello, es pertinente, por ejemplo, la construcción genuina y colectiva de los Acuerdos Institucionales de Convivencia, la conformación de Centros de Estudiantes y otros espacios colectivos de democratización, como las Mesas de Participación Juvenil en el caso de las Escuelas Secundarias. Deben posibilitarse diversas formas de participación que colaboren en la construcción de formas consensuadas de la regulación de los conflictos en todos los niveles y modalidades" (2014: 23). Si bien creemos que el contenido del documento es pertinente como herramienta para resolver conflictos y se posiciona a la vanguardia en términos de derechos humanos, hay mucha distancia entre este contenido y su aplicación -e interpretación- en el día a día de las escuelas secundarias seleccionadas. En estos casos, la implementación de los Acuerdos Institucionales de Convivencia suele reducirse a la confección y al archivo de un escrito que rara vez es empleado para dirimir las diferencias que se viven a diario.
} 
diálogo en cual poder expresar sus preocupaciones, muchos de estos revelaron una fuerte presencia de lo corporal -en tanto cosa física e instrumental- a la hora de resolver sus asuntos. Estableciendo cierta analogía con la preocupación de Meirieu (2007) en lo concerniente a lo que él denomina como "el pasaje automático al acto", pareciera que en la “autorregulación juvenil" el cuerpo sustituye al lenguaje, ya que brinda seguridad y al mismo tiempo ofrece la posibilidad -volátil, riesgosa, impredecible-, de experimentar el goce y la inmediatez sin atender (o, inclusive, exacerbando) las consecuencias.

El debilitamiento del lenguaje es un proceso que se desarrolla de manera directamente proporcional a la experimentación de un cuerpo mudo. La piel y la carne se convierten en los vehículos elegidos por las nuevas generaciones para canalizar la frustración, la ira, la depresión, la tristeza, etcétera. Para un joven incapaz de reconocer límites en una sociedad con fronteras difusas y que, asimismo, no sabe bien cómo expresarse en el plano de la simbolización, el cuerpo pareciera constituir la única exteriorización posible.

Estos modos contemporáneos de experimentar del cuerpo se centran en la constante y creciente búsqueda de sensaciones provenientes de la estimulación física. Para un observador externo, estas prácticas representan un riesgo para la propia vida y para la vida de los demás. La violencia ingresa en este tipo de prácticas, ya que el acto violento pone en juego no solo la propia integridad física, sino también la de los demás; asimismo, el empleo de este recurso también revela una marcada dificultad en la construcción de lazos sociales y en el reconocimiento de ley y la autoridad.

Recurriendo a algunas herramientas conceptuales pensadas originalmente por Lacan -enfocadas en la función constitutiva de la agresividad y la relevancia del lenguaje-, se desarrollaron tres propuestas orientadas a la reivindicación del orden simbólico: la reelaboración positiva del conflicto, la rearticulación cuerpo-lenguaje, y el reconocimiento de la ley. 


\section{Capítulo 4: La relevancia de la escuela en la metabolización de la violencia}

Hoy sabemos, por experiencias desgraciadas del siglo XX, que cualquiera sea el grado de instrucción y el grado intelectual de los individuos, la violencia siempre está y nunca vamos a poder erradicarla totalmente. El trabajo que tenemos que hacer al respecto es más bien de reflexión sobre el origen de esta violencia, pero también sobre la forma de hacerla constructiva, de acompañarla pedagógicamente para que no sea destructiva ni ponga en dificultad el funcionamiento de la institución escolar.

Philippe Meirieu (2007).

\subsection{La representación "optimista" de la escuela}

Tras haber recorrido las principales aristas del controversial -y sensible- problema de la violencia en las escuelas, y luego de desarrollar los principales componentes de la hipótesis, consideramos preciso ahora analizar las medidas que se suelen llevar a cabo en dichas instituciones con respecto a la temática en cuestión. Anticipadamente, podemos decir que la información recolectada en las entrevistas demuestran la coexistencia de dos tendencias contradictorias: por un lado, se suele interpretar a la escuela como un espacio previsto para la civilización y la pacificación de las nuevas generaciones, es decir, como una institución que -por su "naturaleza social"- es enemiga de la violencia. A esta tendencia la denominaremos optimista. Desde otra perspectiva, fundamentalmente ligada a la cobertura de los medios masivos de comunicación, la escuela suele caracterizarse, sin mayores argumentos, como un lugar altamente beligerante en el cual la violencia sería recurrente y fácil de identificar. Designaremos esta tendencia como fatalista.

La tendencia optimista, que mira la escuela como el lugar previsto para el aprendizaje de la no-violencia, se enmarca en un entendimiento de la institución educativa como aquella institución -originada en la modernidad- para la construcción y la reproducción de un modelo ideal de hombre. Siguiendo a Pineau: "sobre este sujeto con estas características -único, esencial, preexistente, soberano, completo, compacto, racional, planificador, activo, autocentrado, limitado, idéntico a sí mismo, etc.- es donde se llevará a cabo la educación moderna" (2008: 86). 
La violencia, recordemos, estuvo históricamente asociada a cierta animalidad o comportamiento primitivo, cualidades que fueron consideradas indeseables y obstaculizantes para el desarrollo del proceso civilizatorio, un proceso específicamente moderno que, de hecho, se construyó a la par de la escuela. "El hombre proviene de la naturaleza, de la animalidad, del azar, de la contingencia, etc., pero debe alejarse de allí, debe desprenderse de esos elementos para surgir puro y limpio y poder expandir y difundir su razón" (Pineau, ibíd:: 87). Con el fin de aplacar estas conductas "naturales" o "esenciales", se implementaron una serie de dispositivos que varían desde el autocontrol producto la influencia de una moral colectiva- hasta la sanción externa, materializada en la sanción disciplinaria (castigo eventualmente acompañado por el uso de la fuerza). ${ }^{71}$

La escuela moderna replicó algunas características propias de la matriz monacal y las reescribió de acuerdo a la lógica de la época. En ese esquema, las paredes que delimitaban el adentro y el afuera de la institución estaban cargadas de un fuerte simbolismo: en el adentro se debía resguardar todo lo bueno de la amenaza que representaba el exterior, lugar de la incertidumbre y la "maldad" (el peligro, la incivilización, la delincuencia, la inmoralidad, los malos hábitos, etcétera). Replicando -y acentuando- la represión del cristianismo al uso individual de la fuerza, la violencia fue ocupando un lugar de exterioridad con relación a la institución educativa.

La escuela se convierte en la caja donde se conserva algo positivo de los ataques del exterior negativo y desde ella debe expandirse para dominarlo. La escuela, templo de la salud, de la civilización, de la Patria, de la tradición, de la razón, de la ciencia, de lo público, conserva e irradia estos bienes sobre el exterior, reino de la enfermedad, de la barbarie, de la antipatria, de la novedad, de la irracionalidad y el azar, del saber nocientífico, de la ley de la selva (Pineau, 2008: 92).

\footnotetext{
${ }^{71}$ Desde un punto de vista educativo-moderno-tradicional, la violencia impartida en las escuelas como parte de una sanción disciplinaria era considerada un acto legítimo. La legitimidad descansaba en el convencimiento generalizado de que en la escuela se debía fabricar, con los medios que fueran necesarios, el modelo de hombre ideal (descripto en el texto principal). Parafraseando a Hegel (1968), el ejercicio de la violencia en el ámbito de la educación escolarizada no solo posee fines correctivos, sino que forma parte del propio acto educativo. A diferencia de la violencia secundaria, impartida por el estado para aplacar las resistencias individuales, según el filósofo mencionado el empleo de la violencia en las escuelas poseía un carácter primario. En otras palabras: dado que el fin último de la violencia institucional conduciría a un apaciguamiento de la sociedad, su uso -aun en las edades más tempranas- era considerado fundador de un orden social. La fuerza en manos de la autoridad escolar tenía como objetivo aplacar la violencia "primordial" u "original" ligada al desconocimiento y la ignorancia; como dijimos, su empleo no solo era considerado legítimo, sino también indispensable. Resumiendo, para Hegel la educación no puede llevarse a cabo sin violencia pedagógica, y para que esto suceda es necesario, primero, vencer cierta "resistencia natural" (ligada a la representación de un mundo desregulado, es decir, carente de restricciones y obligaciones).
} 
Hoy en día, esta caracterización de la escuela como institución "socializadora" y "pacificadora" -aunque con cierto signos de debilitamiento- se sigue sosteniendo (Dussel, 2005). ${ }^{72}$ Si bien no representa la totalidad de las opiniones encontradas, un gran número de docentes y autoridades entrevistados - posicionados desde lo que podría considerarse un "deber ser"- se refieren a la institución en estos términos, es decir, evidenciando la permanencia, al menos en el plano discursivo, de ciertas representaciones asociadas a la transmisión de la no-violencia. A continuación seleccionamos algunos fragmentos extraídos de tres entrevistas a una integrante de un Equipo Distrital de Infancia y Adolescencia, un profesor de Construcción de la Ciudadanía (perteneciente a la "escuela del centro") y un preceptor (con funciones en la "escuela del barrio ferroviario"):

Si el conflicto es inherente al ser humano, la educación es el antídoto para poder regular los vínculos; y lo produce en grandes masas porque lo produce en Argentina como estado [...].Uno escucha "la escuela está cada vez peor", y en realidad nosotros pensamos que es al revés. Los chicos van a estar atravesados por cuestiones simbólicas que nosotros no tuvimos, en nuestras épocas no había centros de estudiantes, no teníamos espacios de exposición ni espacios de voz, no podíamos decir lo que nosotros pensábamos [...]. En realidad la escuela sigue sosteniéndose, y la verdad que es la mejor forma de educar.

Si algo tiene como objetivo nuestra escuela es educar para la paz, entonces todas las situaciones se van a hablar y a escuchar.

La escuela puede sacar buena gente o mala gente. Yo prefiero que la escuela saque buena gente. Y hay que colaborar en eso ipor qué? Porque esa buena gente o mala gente el día de mañana se va a cruzar con mi hija por ejemplo [...]. Yo sé que puedo hacer algo en ese lugar, en las escuelas. Para el día de mañana sacar buenos pibes y no delincuentes.

En los últimos años, la caracterización de la escuela como lugar de la civilización y la pacificación se ha entrelazado a menudo con paradigmas político-educativos vinculados en algún punto con la democracia y la inclusión. Estas tendencias repercutieron de manera directa en las medidas que debían tomarse para analizar y resolver los problemas

\footnotetext{
${ }^{72}$ Sobre el papel de la escuela como institución prevista para la socialización y la pacificación, consideramos oportuno atender los aportes de Dussel, quien afirma que, si bien su hegemonía muestra claros signos de crisis, esta institución aún perdura -sobre todo en el plano discursivo- como un lugar indispensable para la transmisión de cierto orden disciplinario, materializado en "la cultura política educativa y en las formas en que se piensa la convivencia, el disenso y el conflicto en las escuelas" (2005: 1110). La misma autora también advierte que, si bien esta función se mantiene intacta en los discursos educativos, "esto no es lo que efectivamente sucede en las escuelas" (ibíd.). Este desencuentro entre lo que se dice y lo que ciertamente acontece en los colegios en materia de convivencia, es una constante que se advirtió en muchas de las entrevistas realizadas a directivos y docentes. $\mathrm{Al}$ mismo tiempo que varios de estos agentes se pronunciaron en reiteradas ocasiones como impulsores de, en sus propios términos, una "educación democrática" o una "educación para la paz", también reconocieron -generalmente asumiendo una postura conservadora en la descripción de los acontecimientos- la presencia constante de conflictos señalados como violentos. Creemos que este tipo de contradicciones nos obliga a reflexionar una y otra vez sobre las confusiones y las arbitrariedades que suelen rodear la temática en cuestión.
} 
comúnmente asociados a la violencia. De un tradicional enfoque penalizante y estigmatizador se pasó a una orientación más "reflexiva" (Dussel, 2005), centrada en la contextualización de los problemas, y se dirigió la atención, ya no hacia el "culpable" del acontecimiento violento, sino hacia los elementos desencadenantes y en las condiciones del entorno. ${ }^{73}$ En este sentido, varios estudios realizados a mediados de la década pasada intentaron mostrar que la idea de "convivencia" es superadora de la "disciplina" en términos de derechos educativos. Mientras que la disciplina históricamente fue utilizada como instrumento para señalar acciones como buenas o malas, correctas o incorrectas, bajo el paradigma de la convivencia se intenta desarrollar una concepción "más amplia que hace referencia a los modos de estar junto con otros y a la manera en la que es transitada esta experiencia" (Nuñez, 2015: 66).

Estos nuevos modos de interpretar los conflictos e intervenir sobre ellos, introdujeron -y pusieron en el centro de la escena- la preocupación por "el contexto", es decir, la consideración de los vínculos familiares, los problemas barriales, las relaciones intergeneracionales y el clima escolar. ${ }^{74}$ De esta manera, una amonestación, un cambio de turno, una suspensión o una expulsión, no solo fueron consideradas medidas obsoletas e ineficaces, sino que a partir de la nueva Ley de Educación Nacional pasaron a constituir medidas antirreglamentarias. Desde el punto de vista de Dussel, actualmente asistimos a un “desplazamiento de las formas disciplinarias centradas en la autoridad burocrático-legal a

\footnotetext{
${ }^{73}$ Dussel identifica los comienzos de esta tendencia "reflexiva" sobre las cuestiones disciplinares del sistema educativo argentino hacia finales del siglo pasado, cuando las discusiones acerca de la autoridad docente y su estado de crisis requirieron poner en práctica medidas o estrategias alternativas a las empleadas hasta ese momento. Centrando la atención en los nexos entre el orden disciplinario escolar y el político, la autora mencionada afirma: "hacia finales de la década de los noventa, surge un renovado interés en la disciplina y el gobierno escolar, esta vez impulsado por preocupaciones por la crisis de la autoridad adulta y por el desdibujamiento de las fronteras entre lo permitido y lo prohibido" (2005: 1111). En línea con la democratización del sistema educativo iniciada en los ochenta, estas actualizaciones se enfocaron -no con pocas dificultades- en ampliar la participación de docentes, estudiantes y padres en todas aquellas decisiones vinculadas con la convivencia escolar.

${ }^{74}$ Cornejo y Redondo definen el clima escolar como "la percepción que tienen los sujetos acerca de las relaciones interpersonales que establecen en el contexto escolar (a nivel de aula o de centro) y el contexto o marco en el cual estas interacciones se dan" (2001: 28). Varias investigaciones referidas a la violencia en las escuelas suelen incluir la influencia del "clima escolar" o el "clima institucional" como uno de los factores determinantes en el desencadenamiento de conflictos violentos. Entre estos estudios se destaca el desarrollado por D’Angelo y Fernández, publicado con el título: Clima, conflictos y violencia en las escuelas. En dicho escrito, los autores afirman que "la cuestión de los climas escolares ocupa un lugar central en las investigaciones sobre la violencia en las escuelas, en la medida en que permite desmarcarse de los determinismos fatalistas y comenzar a interrogarse sobre la posibilidad de una intervención activa de la institución escolar en relación con la gestión del conflicto y la violencia” (2011: 23).
} 
formas reflexivas [...], fundadas en discursos psico-pedagógicos y en la idea de contrato o negociación con los niños y jóvenes" (2005: 1110). Sobre este pasaje de un tratamiento individual de la violencia a una interpretación considerablemente más amplia, democrática y contextualizada, Kornblit manifiesta:

Los intentos de dar cuenta de estos procesos desde el campo académico atravesaron un camino desde el énfasis puesto en los problemas individuales de los alumnos, en cuanto a sus características personales y familiares -discurso que abrevaba en la impronta de la psicología en las ciencias de la educación-, a enfoques socioculturales que toman en cuenta tanto el proceso de los factores estructurales en la vida escolar como los psicosociales (2008: 11-12).

En algunos discursos de los adultos entrevistados fue posible rastrear -en ocasiones con matices contradictorios- algunas referencias a lo que podría considerarse "nuevos enfoques" o "nuevos paradigmas" en materia de resolución de conflictos. En esta línea, consideramos pertinente atender a las siguientes opiniones:

Hay que tratar de entender más a los jóvenes, porque si nos quedamos con la sentencia de que fulano es irrespetuoso, consume, es un violento... y si nos quedamos solo con eso estamos en el horno. Hay que tratar de tener una mirada más crítica. Bueno... a ver, qué le estará pasando a este alumno, qué está sucediendo en la vida de este joven que hace que actúe así. Porque si nos quedamos con lo que vemos, con la apariencia, con el joven violento, con el que consume, con el que insulta, con el inquieto... ahí es imposible hacer algo (integrante del Equipo de Orientación Escolar de la "escuela de la periferia norte").

En nuestras épocas no había centros de estudiantes, no teníamos espacios de exposición ni espacios de voz, no podíamos decir lo que nosotros pensábamos. Hoy todos los sujetos tienen ese lugar prioritario, y eso también supone mayor ejercicio de la democracia, que todavía no lo tenemos (integrante de un Equipo distrital de Infancia y Adolescencia).

El proceso social se supone que en la primaria ya se está trabajando, el chico aprende a compartir, aprende a convivir, va adquiriendo hábitos, entonces si acá hubo un momento de tensión y estrés hay que hablarlo y hay que trabajarlo, pero no sacarlo [...]. Si vos sacas a un chico de la escuela estás vulnerando el derecho a la educación que es primario, es como comer (vicedirectora perteneciente a la "escuela del barrio ferroviario").

Yo creo que la sanción por sí misma, sin el diálogo, sin la reflexión, sin la búsqueda de nuevos acuerdos, y sin la posibilidad de una reflexión escrita; una reflexión con la familia, es absolutamente obsoleta, no tiene sentido [...].Por eso siempre hablamos de sanciones reparadoras, o de restitución de acuerdos, o de búsqueda de información. En ningún momento hablamos de expulsión (directora perteneciente a la "escuela del barrio ferroviario").

En lugar de "sentenciar" y "quedarse con las apariencias", la integrante del Equipo de Orientación Escolar de la "escuela de la periferia norte" propone desarrollar una "mirada crítica", esto es, adentrarse en la vida del joven para indagar lo que le sucede, lo que lo perturba, lo que lo intranquiliza. En otras palabras, la propuesta se centra alrededor de la pregunta: ¿qué es lo que acontece en la vida de un joven, fundamentalmente en la relación 
que tiene con su familia, la escuela y sus pares, para que este se haya visto tentado a hacer uso de la violencia?

Estos nuevos enfoques, más orientados a proteger al alumno que a castigarlo con una sanción penalizante, se erigen sobre la presunción de que las medidas disciplinarias tradicionales no solo no evidencian avances en la mitigación de los hechos comúnmente considerados "violentos", sino que además atentan contra los derechos de los jóvenes. Es preciso aclarar que este nuevo paradigma en lo que refiere al tratamiento de la violencia en escenarios escolares, lejos de reducirse a una experiencia aislada o a una moda pasajera, se materializó en diversas normativas, protocolos y guías de carácter oficial, en concordancia con las políticas públicas condensadas en la Ley 26.206 de Educación Nacional.

Ahora bien, como ocurre con toda reforma, estos modos "más democráticos" de tratar de resolver los conflictos, si bien evidenciaron un importante avance en lo que respecta al cuidado y la garantía de los derechos humanos y los derechos de los niños, también desencadenaron algunas resistencias y confusiones a la hora de determinar "qué hacer" en materia de convivencia escolar. En un estudio desarrollado por Litichever (2012) sobre las normas de convivencia en varias escuelas secundarias de Argentina, es posible advertir que la indecisión, la confusión o el temor de los adultos por no saber "qué hacer" frente a las problemáticas más frecuentemente visibilizadas en los últimos tiempos (agresiones físicas, portación de armas, toxicomanía, delincuencia, corrupción, entre otras), suele advertirse en el contenido -explícito e implícito- de los reglamentos de convivencia. Conjuntamente con una serie de mandatos históricamente asociados a la regulación de la cultura escolar (como la apariencia, el cuidado de la institución y el respeto por los símbolos patrios), estos documentos -más exactamente aquellos confeccionados entre la década del noventa y la actualidad- dejan traslucir la permanencia -y la naturalización- de varios temores por parte de los educadores. En palabras de Litichever:

En la letra de los reglamentos se incorporan nuevas temáticas [...], lo que indica la presunción, por parte de los actores institucionales de que, en un momento u otro, ocurrirán. La percepción de los docentes, preceptores y equipo directivo de que los alumnos pueden desplegar una serie de transgresiones novedosas, más allá de que efectivamente las realicen, lleva a plantear las interacciones de manera diferente (2012: 7).

Siguiendo esta línea, podría decirse que los reglamentos de convivencia representarían algo así como un reflejo o la materialización de las demandas y las expectativas que los adultos construyen sobre los jóvenes (sobre todo en relación a las 
problemáticas más resonantes de los últimos tiempos). De esta manera, asentándose sobre el mandato histórico de que la escuela es el lugar ideal para transmitir el rechazo a la violencia, muchos docentes y directivos encuentran en estos documentos un espacio para plasmar, no solo cuestiones vinculadas con la convivencia, sino también una serie de valoraciones que podrían leerse como preconceptos y estigmatizaciones derivadas de un clima de época atravesado por cierta paranoia y por la presunción de que las poblaciones jóvenes son más proclives a cometer actos ilegales. ${ }^{75}$ Así, resulta significativo el hecho de que:

En las escuelas que atienden a sectores populares se concentran con mayor preponderancia en sus reglamentos normas para neotransgresiones que refieren a la violencia, la delincuencia y allí se enuncian pautas en relación a la prohibición de ingresar con armas y otras vinculadas a los robos. En la enunciación de este tipo de normas parecen operar los efectos de una serie de supuestos y expectativas de los agentes escolares respecto de los barrios populares en los que se ubican las escuelas sobre la percepción de peligrosidad extrema (2012: 8). ${ }^{76}$

El contenido de estas reglamentaciones, siguiendo la línea de Litichever (2012; Litichever y otros, 2008), nos permite vislumbrar una serie de constantes -inmiscuidas entre cuestiones procedimentales inherentes a la cotidianeidad de las instituciones-, tendientes a la naturalización de ciertas idealizaciones y expectativas vinculadas con lo aquí hemos decidido nombrar "una representación optimista de la escuela".

\footnotetext{
${ }^{75}$ En línea con lo que podría caracterizarse, sintéticamente, como una mirada sesgada de la juventud, consideramos pertinente atender brevemente a los aportes de Núñez (2015) y Chaves (2010). A partir de una serie de investigaciones enfocadas en la discriminación en el nivel secundario, particularmente en la asignación de ciertos "rótulos" o "etiquetas", Núñez (2015) advierte que el señalamiento de, por ejemplo, el "desertor" o el "libre", en lugar de promover la asistencia a clases, recrudece aún más el problema original, ya que introduce una fuerte carga social negativa (legitimada en la valoración positiva del sacrificio y la meritocracia). Chaves (2010), por su parte, pone el acento sobre los efectos nocivos de la "vulnerabilidad". Esta circunstancia, en ocasiones materializada en la percepción de algún tipo de subsidio personal o familiar, cristaliza una serie de representaciones negativas sobre los jóvenes señalados como "pobres" o "vulnerables" que los sitúan en un lugar de negatividad de sus posibilidades. En resumen, podríamos decir que la estigmatización de los jóvenes en edad escolar es un ejercicio -a veces inconsciente-, que se nutre de una serie de preconceptos cargados con una fuerte connotación negativa. Lejos de tratarse de un asunto menor, creemos que esta situación repercute directamente sobre el problema de la violencia, ya que este tipo de caracterizaciones -de manera más o menos explícita- favorece el establecimiento de un clima sesgado por la desconfianza y el distanciamiento (alimentado, en muchos casos, por agentes escolares adultos que, en ocasiones involuntariamente, colaboran con la producción y reproducción de diversos prejuicios).

${ }^{76}$ La neotransgresión es un término empleado por Litichever para designar nuevas posibles faltas relacionadas con la delincuencia, la drogadicción, la agresión física, la corrupción, la falsificación de la identidad, entre otras. Se trata de nuevas conductas que habitan (o se presupone que lo hacen) el actual escenario escolar y que se traducen de manera diferente en cada una de las instituciones (Litichever y otros, 2008).
} 


\subsection{La representación "fatalista" de la escuela}

En contraposición a la caracterización de la escuela como aquel lugar favorable para transmitir valores asociados a la civilización y la pacificación, en los últimos tiempos es posible advertir la presencia cada vez mayor de cierta interpretación fatalista de la misma. Esta nueva tendencia parte de la premisa de que la institución educativa, y más aún el nivel secundario, se ha convertido en un lugar donde predomina el descontrol y la violencia. Dicha concepción se fundamenta, en términos generales, en una profunda crisis que afectaría -simbólica y materialmente- el modelo de la escuela moderna-tradicional. Tal como afirma Pineau: "en la actualidad, la crisis de la modernidad da lugar a una crisis de la escuela, ya que las bases -modernas- sobre las que la institución se construyó y se justificó han perdido validez" (2008: 84).

Esta caracterización fatalista no solo parte de la creencia de que la escuela ya no representa lo que históricamente representó en materia de educación y cuidado de las nuevas generaciones; además, incorpora la violencia como un problema "evidente", "dado", "incuestionable". En esta línea, Duschatzky y Corea afirman que "la escuela sabe -mejor dicho, supo- mucho de los tiempos estables, regulares y de progreso. Supo de ello porque fue creada en tiempos estables, en condiciones regulares, y para asegurar el progreso. Pero no se trata de eso ahora" (2013: 9).

El ejemplo más representativo de esta visión fatalista de la escuela posiblemente se encuentre en las caracterizaciones realizadas por los medios de comunicación, más específicamente, en las dramáticas coberturas que suelen hacer de los casos comúnmente asociados a la violencia. Esta situación ha sido advertida por varios autores dedicados a la problemática desarrollada (Bleichmar, 2008; Kornblit, 2008; D’Angelo y Fernández, 2011; Kaplan 2015, entre otros): sus investigaciones, por lo general, coinciden en considerar a los medios como un elemento clave en la reiteración, magnificación y, en cierta forma, en la misma creación del -debatible- concepto "violencia escolar". Tal como afirman Brener y Kaplan:

La "violencia escolar" se ha transformado en una suerte de categoría dada: prácticamente se ha constituido en una sección autónoma de periódicos gráficos, revistas de circulación masiva, en columnas de numerosos periodistas televisivos, así como en preocupación constante de columnistas y formadores de opinión de emisoras radiales. De este modo, empieza a no resultar tan excepcional que la vida escolar esté atravesada por imágenes que parecían ser exclusivas de otros espacios sociales (2015: 81). 
Esta cosificación de la "violencia escolar" favorece la reproducción de cierta paranoia social que recae, indiscriminadamente, sobre todo lo que remite en algún punto a las relaciones mediadas por "lo escolar", afectando determinantemente el valor simbólico de la escuela media en nuestro territorio. Parafraseando a Southwell (2018), la "violentación" de la escuela secundaria se alinea a una serie de críticas relacionadas (rastreables desde mediados del siglo XX) que deben ser revisadas, no solamente en su validez, sino también en sus efectos destructivos sobre el valor simbólico del sistema educativo público.

El modo en que se suele graficar esta tendencia fatalista se caracteriza por una exposición vertiginosa de imágenes sangrientas, brutales y explícitas, como si se tratara de la cobertura de una guerra (aunque, vale la pena aclarar, en estos ámbitos el objetivo de los periodistas son alumnos y docentes en contextos formativos). Al abordar la problemática, los medios de comunicación "enuncian a la violencia escolar con una contundencia y precisión que pareciera tratarse de un fenómeno terminante, indiscutible, que no amerita ningún tipo de explicación” (Brener y Kaplan, ibíd:: 80). Muchos adultos entrevistados también advierten que las noticias asociadas a la violencia comúnmente se encuentran impregnadas por un alto contenido de sensacionalismo y pesimismo. En sus términos:

El contenido de los noticieros en un noventa por ciento de violencia, que no deja de ser la realidad. Lo que hay que revertir es eso, y la mirada ante eso, para que no sea una cosa cotidiana y normal [...]. Me parece que los medios magnifican, las cosas pasan, pasaron siempre, pasan en todos lados y en todo el mundo. Hemos visto que un chico puede entrar a una escuela de Estados Unidos con un arma y mata a 10 pibes. Entonces no me vengan con que es acá, con que es en la provincia de Buenos Aires (vicedirectora, "escuela de la periferia norte").

Programas de violencia callejera, programas de violencia entre adolescentes, el empoderamiento del macho frente a la mujer, frente al otro macho, el golpe como una búsqueda de solución al conflicto... son cosas que están presentes en la mayoría de los programas de televisión (directora, "escuela del barrio ferroviario").

Los medios están todo el día bombardeando. El tema es que muestran mucho, muestran la misma noticia una y otra vez. Te la pasan, te la recontra vuelven a pasar, y te la vuelven a pasar [...]. Están todo el tiempo mostrándote violencia, violencia, violencia (preceptora, "escuela de la periferia norte").

Hoy día se ha hecho frecuente observar en los noticieros de mayor audiencia en Argentina, en sus horarios centrales, la exposición de la cara magullada de un maestro, peleas entre alumnos (tanto en el interior como en el exterior de los colegios), amenazas de padres a docentes, docentes que arrojan objetos hacia su clase, solo para mencionar unos 
pocos ejemplos. La mayoría de estas capturas suelen realizarse con teléfonos móviles y posteriormente son publicadas en diversas redes sociales. Una vez allí, las imágenes y videos son captados y ampliados por diversos medios televisivos, los cuales intentan resaltar el plano más explícito posible. Acto seguido, el material obtenido es repetido varias veces al día. La frecuencia suele variar de acuerdo a la gravedad del hecho, llegando a reiterarse en cada resumen de hora, con una frecuencia cada vez menor, hasta que luego de dos o tres días desaparece de escena; esta progresiva desaparición, generalmente, es reemplazada con la cobertura de un nuevo caso. Este tratamiento -curiosamente sistemático- de la información pareciera alimentar un tema cuya significación no es discutida; parafraseando a Brener y Kaplan (2015), se trata de una trama que, a primera vista, se revela como algo dado, terminante, indiscutible.

Una hipótesis posible es que otros discursos, principalmente el de los medios de comunicación masiva, podrían estar contribuyendo a magnificar el fenómeno de la violencia en las escuelas y esto tendría una incidencia considerable en la percepción de los actores respecto de su gravedad (D’Angelo y Fernández, 2011: 9).

Ampliando lo expuesto en el primer capítulo, creemos que las noticias que se suelen incluir en lo que podría denominarse "la sección de la violencia escolar" resultan discordantes con la realidad que se vive día a día en las escuelas secundarias de la ciudad de La Plata. Palabras tales como: agresores, bandas, víctimas, ataque, defensa, muertos, heridos, internados, revelan un abordaje de la noticia que permite entrever una marcada connotación negativa. Para centrar la atención y magnificar el contenido "violento" de la crónica, en ocasiones los hechos son enunciados con el foco dirigido hacia la imagen más impactante: la sangre, la herida, la lesión, las roturas, los testimonios más dramáticos, etcétera. Creemos que esta distorsión intencionada de los hechos, en consonancia con cierta representación social de la delincuencia juvenil, acentúa la producción y la reproducción de una imagen fatalista de la institución educativa. Desde este punto de vista, la escuela es considerada un lugar donde ocurren cosas "malas", "peligrosas", "destructivas" -en suma, un lugar que sería mejor evitar-.

Esta nueva rotulación de la escuela como una institución violenta en sí misma, como un organismo catalizador de violencia, supone una ruptura con una de las máximas que históricamente caracterizó a la educación pública: la proyección de un mejor porvenir. La distorsión de la idea de progreso asociada al paso por la escuela, o, en otros términos, la presunción de que esta institución ya no es el lugar más apropiado para la socialización de 
las nuevas generaciones (o, desde otra perspectiva, la caracterización de la escuela como una especie de antro malicioso y altamente conflictivo en el que los jóvenes pueden "contaminarse" de hábitos vinculados a la violencia, la delincuencia y el vagabundeo), es una de las constantes -peligrosamente descalificadora- que puede advertirse en el tratamiento mediático de la problemática aquí estudiada. Algunos fragmentos extraídos del diario más popular en la región pueden considerarse "pruebas" de lo hasta aquí desarrollado:

El problema reviste una extraordinaria complejidad y exige, además de los diagnósticos que puedan servir como puntos de partida, la adopción de una verdadera política de Estado que se ocupe de enfrentar los desafíos de la infancia y la juventud, ofreciéndose desde allí la apoyatura y el respaldo imprescindibles para que el sistema educativo vuelva a ser lo que fue durante tantas décadas en nuestro país: un ámbito excelente de formación y no un escenario más para la violencia (diario El Día, 2 de mayo de 2014). ${ }^{77}$

La madre de un alumno golpea a una maestra porque a su hijo le puso notas bajas; otro alumno amenaza a una profesora porque no lo eximió en su materia; un grupo de tres alumnas golpean a otra hasta desfigurarla por el solo hecho de ser "linda". Episodios como estos se reiteran dentro y fuera de las escuelas con actos de violencia que parecieran no tener límites (diario El Día, 2 de diciembre de 2014). ${ }^{78}$

Padres extremadamente preocupados piden ayuda a gritos para que se encauce la situación y deje de ser un espacio signado por la violencia, cada vez más fuerte y sin tener límites en el horizonte [...]. Algunos no se animan a llevar a sus hijos por temor a que les ocurra algo grave dentro del colegio; y otros los llevan a la escuela con la sensación del temor en cuerpo y alma, pero tratan de estar lo más cerca posible, haciendo guardias a metros del colegio, en situación de extraña alerta (diario El Día, 25 de agosto de 2017). ${ }^{79}$

Hemos asistido en los últimos días, a crónicas periodísticas que dieron cuenta de incendios, ataques y roturas varias en establecimientos educativos de la Región [...] ¿Por qué ocurren estos hechos? Porque la escuela ha dejado de formar en valores (diario $\mathrm{El}$ Día, 2 de noviembre de 2017). ${ }^{80}$

Lejos de reducirse a unos pocos periódicos o medios televisivos, la caracterización

fatalista de la escuela -sobre todo en las instituciones de nivel secundario- se replica cada vez con más recurrencia en la opinión pública; en ocasiones, son los propios educadores

\footnotetext{
${ }^{77}$ Fragmento extraído de una nota editorial titulada: "Toda la sociedad, desafiada por el flagelo de la violencia en las escuelas", vinculada a un hecho acontecido en una escuela secundaria de la ciudad de Junín.

${ }^{78}$ El escrito corresponde a las primeras líneas de una nota titulada: “¿Cuáles son los límites de la violencia en las escuelas?" En la misma se relata un episodio en el que una alumna de un colegio secundario público habría envenado a un profesor colocando una sustancia tóxica dentro de una botella de agua.

${ }^{79}$ El texto citado corresponde a una nota titulada: "El aula, un territorio hostil", de autoría anónima y ubicada inmediatamente después de la crónica de un hecho en el que un grupo de estudiantes de una escuela primaria de La Plata se habría trenzado a golpes en el baño del establecimiento.

${ }^{80}$ Las palabras seleccionadas pertenecen a un directivo entrevistado por el diario con el motivo de incluir una evaluación profesional en relación a una serie de eventos ocurridos en una plaza de la ciudad de La Plata, donde varios grupos de jóvenes -supuestamente pertenecientes a colegios secundarios de la región- se habrían enfrentado a goles.
} 
quienes revelan -tal como se desprende de los testimonios brindados para la presente investigación- la presencia de un discurso alarmista sobre la violencia. En el relato de la vicedirectora de la "escuela de la periferia norte" citada más arriba, es posible entrever la pregnancia de un recurso lingüístico característico de los medios de comunicación: la referencia a otros casos -acontecidos en otros tiempos o en otras regiones geográficas- con el fin de dramatizar o recrudecer la información original. Si bien la vicedirectora reconoce que el asunto de la violencia es un tema recurrente en los medios de comunicación (en sus propios términos, "que los medios magnifican"), a la hora de emitir una opinión propia sobre los problemas comúnmente asociados a la violencia en la escuela donde ella trabaja, hace una referencia a las masacres escolares de Estados Unidos como parámetro para medir los alcances y la frecuencia de los acontecimientos ocurridos en su colegio.

La caracterización fatalista de la escuela lleva ínsito un problema de carácter filosófico: si anteponemos la imposibilidad como rasgo predominante al problema de la violencia, la escuela nunca será capaz de resolver o atenuar ninguna clase de conflicto. Lejos de tratarse de un asunto de menor importancia, esta supuesta inutilidad de la institución educativa pone de relieve los efectos nocivos de cierta representación catastrófica. Dicho de otro modo, si la escuela nada puede hacer para mitigar los hechos comúnmente catalogados como violentos, entonces el problema de la violencia constituye la cara visible de un asunto considerablemente más grave, como es la propia legitimación de la escuela pública.

Como muchos docentes y autoridades entrevistados no confían en que la escuela en la que trabajan posea recursos para mitigar los conflictos "violentos", entonces optan por asumir una posición de espectadores-críticos: culpan al sistema, a los inspectores, a los directivos, a los alumnos, a los padres, a los ministros, a sus colegas, etcétera. Siguiendo esta línea, consideramos oportuno preguntarnos: ¿cómo es posible que docentes y autoridades convivan a diario con un malestar generalizado sin hacer nada al respecto? ¿Qué sucede cuando alguien pretende hacer algo en relación al asunto de la violencia? ¿De qué herramientas dispone? ¿Con que obstáculos suele encontrarse? ¿Qué respaldo tiene? El testimonio de un preceptor (perteneciente a la "escuela del barrio ferroviario") puede servir para ahondar aún más en las cuestiones planteadas. Refiriéndose a un episodio en el que descubre a un grupo de alumnos fumando marihuana dentro del colegio, el docente explica: 
Vos tenés muchas pautas a seguir, pero no te dan estrategias. Vos ves que el instructivo ese de situaciones de riesgo dice: ${ }^{81}$ en caso de que veas a un chico presuntamente consumiendo sustancias, marihuana o lo que sea, tenés que llamar al $\mathrm{CPA}^{82}$ e informar al equipo. También hay que llamar a los padres con total discreción.

El estado te baja ciertas medidas a tomar pero cuando vos querés llevarlas a cabo, te das cuenta que no tenés los medios. Todo es en apariencia y sobre las apariencias no podés hacer nada, entonces desde ese punto ya se te dificulta. Si tenés que llamar a un CPA, llamás a un CPA y no te contestan nunca. Cuando te contestan, no tienen personal para mandarlo, y si tienen personal para mandarlo, necesitan autorización del directivo porque va a ir alguien externo... y el directivo nunca firma ese pedido. Entonces tratás de derivarlo al equipo de orientación, al asistente social, al gabinete. Y en el gabinete, ¿qué te dicen? Que no se van a meter en eso porque en temas de droga tienen miedo; entonces queda ahí. Queda un acta que yo hago y le muestro a un directivo que nunca firma. En lugar de guardar el porro, el directivo - para no tener problemas- lo rompe en mi cara, lo tira. Y después me dice a mí que lo rompió porque no se dio cuenta. Y en realidad lo rompió porque si lo guarda está obligado a mandarlo a analizar. Porque el reglamento te dice eso, que vos tenés que mandarlo a analizar. Y cuando están seguros de lo que es, ahí siguen otros pasos.

Al final es más fácil no haber visto nada o fumártelo vos con los pibes, vas a tener menos problemas... yo pasé a ser el hijo de puta que no quería porro. Además me preocupó que yo al salir de la escuela, estando en la parada de micro, un auto se paró y me dijo: "¿así que vos sos el preceptor?" Y se rieron; el mismo día del porro. Y nadie dice nada; yo fui cagado a la escuela un par de días porque no sabía qué onda; entonces te das cuenta que no tenés respaldo de nadie.

Si bien esta investigación se asienta sobre un manifiesto rechazo a la caracterización fatalista de la escuela, el relato del preceptor nos obliga a cuestionarnos respecto de la permanencia de ciertos elementos obstaculizantes para el tratamiento de las diversas problemáticas que suelen acontecer en las escuelas secundarias seleccionadas. En su testimonio se pueden distinguir: la elusión, el desentendimiento, el escape de los adultos responsables, el exceso de burocracia, la falta de medios, la ambigüedad de ciertos discursos y las presiones externas a la institución. Con tales impedimentos es admisible que alguien -más allá de la función que desempeñe- se sienta superado por las circunstancias y opte por no hacer nada para mejorar las condiciones de su lugar habitual de trabajo. En la misma línea, muchos adultos entrevistados expresaron su descontento con respecto a las normativas disponibles para el tratamiento de la violencia en contextos escolares. Con fines analíticos, condensamos estas críticas en tres grupos: insuficiencia, irrelevancia y alteración; a continuación ampliaremos su desarrollo.

\footnotetext{
${ }^{81}$ Se refiere a la Guía de orientación para la intervención en situaciones conflictivas y de vulneración de derechos en el escenario escolar, publicada por el Ministerio de Educación de la Nación en el año 2014.

${ }^{82}$ Sigla que hace referencia a los Centros Provinciales de las Adicciones (organismos dependientes de la Provincia de Buenos Aires).
} 


\subsection{1) Insuficiencia}

Muchos de los entrevistados caracterizan a las normas previstas para la resolución de situaciones conflictivas como débiles, flojas o poco contundentes. Entre los documentos a los que se suele hacer referencia se destacan: la Guía de orientación para la intervención en situaciones conflictivas y de vulneración de derechos en el escenario escolar, el Programa de reformulación de normas de convivencia y disciplina y la propia Ley 26.206 de Educación Nacional. Una de las constantes que puede trazarse en el discurso de varios informantes adultos es la falta o la insuficiencia de instancias y organismos que deberían acompañar la puesta en marcha de las normativas mencionadas. En ocasiones, estas demandas se entremezclan con una especie de nostalgia o reivindicación de los antiguos sistemas de sanciones (basados en amonestaciones, suspensiones y expulsiones). La expresión de estos reclamos se suele centrar en el supuesto -hoy antirreglamentario- de que tales normativas, por contemplar cierta dureza, eran más efectivas a la hora de tratar asuntos vinculados con la violencia. Entre las críticas relevadas se destacan las siguientes:

Las faltas existen y están dentro del acuerdo de convivencia, lo que no está definido es la máxima, le falta, está incompleto [...]. Todo se centra ahora en el código institucional, a mí me gustaría que vos lo revises y veas que hay puntos en el código institucional que se quedan sin respuesta frente a hechos de violencia, porque te quedás sin herramientas (profesor en Construcción de la Ciudadanía, "escuela del centro").

Expulsiones no hay, pero para mí tendría que haber. A mí me pueden decir "vos sos un hijo de puta porque no estás incluyendo nada, a vos no te importa sacar a un pibe de la escuela". Yo prefiero sacar uno y que no se me vayan diez. [...] Muchos buenos pibes se fueron por el tema de la droga. Entonces no me sirve seguir reteniendo gente, yo prefiero el sistema antiguo de expulsión [...], que el pibe sienta que perdió algo, que al padre se le complique la vida. Y yo no te digo que esto es una solución, esto es sacarse un problema de encima también. Pero yo prefiero sacarme un problema de encima a que se me vayan cinco o seis buenos (preceptor, "escuela del barrio ferroviario").

Como muestra el segundo testimonio, esta demanda por sanciones más determinantes coexiste en ocasiones con el temor de evidenciar un posicionamiento "autoritario" o "excluyente" que exhiba tal rasgo públicamente o que ponga en juego su continuidad laboral. $^{83}$ Este posicionamiento crítico -pero cauto al mismo tiempo- da cuenta de la

\footnotetext{
${ }^{83}$ Este pronunciamiento ambivalente fue un elemento que se reiteró en varias de las entrevistas realizadas a docentes, autoridades e integrantes de Equipos de Orientación Escolar. Inmediatamente después de una opinión contraria al pensamiento "oficial", muchos entrevistados preguntaron acerca del destino de la información compartida, como si al escucharse a sí mismos y reflexionar sobre lo dicho se plantearan qué acontecería si dijeran en público lo que dijeron.
} 
presencia de ciertas confusiones respecto a la aplicabilidad y efectividad de las medidas "reparatorias" (vigentes en el período relevado). Provisoriamente, podemos decir que esta (supuesta) falta de instancias institucionales -que deberían acompañar la ejecución de las ordenanzas antes mencionadas- posiblemente se corresponda con el carácter novedoso y rupturista de las políticas proteccionistas de niños y adolescentes. Además de eso, la aplicabilidad de estas nuevas ideas se desarrolló sobre la base un sistema educativo pensado y diseñado en el siglo XIX, cuya estructura, si bien tuvo su momento de esplendor, adentrado el siglo XXI muestra inocultables contradicciones en el tratamiento de situaciones conflictivas. $^{84}$

\subsection{2) Irrelevancia}

Otra constante que se evidencia en la opinión de los entrevistados adultos es que la redacción y la publicación de las normas escolares no suelen estar acompañadas por un acuerdo generalizado a la hora de determinar cuándo y cómo ponerlas en práctica. Así, aunque no desconocen el hecho de que la escuela está regulada por ciertas reglas (comúnmente plasmadas en los acuerdos de convivencia), varios educadores manifestaron que estos documentos, por lo general, no son respetados.

Con respecto a la perspectiva de los jóvenes, consideramos pertinente recuperar un fragmento de la entrevista realizada a un grupo de alumnas pertenecientes a la "escuela del barrio ferroviario".

Alumna 4: -Yo me agarré a piñas afuera de mi casa ¿viste esa época en que le decían bicho feo a todo el mundo?... Yo les decía bicho feo a mis amigos. Dos pibitas pensaron que les dije eso y parece que se lo tomaron mal, se dieron vuelta y me empezaron a mirar mal, empezaron a bardear. Una me dice: “¿qué decías vos?”...Y yo le estaba hablando a un amigo, entonces la piba me dice "vos cortala" mientras se iba. Le digo "vos cortala qué", entonces voy y la busco y nos agarramos a piñas afuera de mi casa [...]. Se metió mi hermana y la empezó a rasguñar, entonces yo la saqué para que no la rasguñe y viene la otra de atrás para pegarme a mí. Cuando me pegó me di vuelta y le agarré la remera porque se quería ir. Después me agarró con un palo y también me quiso agarrar una señora de 30 años que me pegó en la cabeza; todavía tengo un chichón.

Alumna 1: - Y denunciala!

Alumna 4: -No llegan a ningún lado las denuncias [...]. La denuncia no sirve, si esta señora ya tenía un par por pegar [...].

\footnotetext{
${ }^{84}$ Estas contradicciones se centran en el carácter excluyente de las antiguas medidas disciplinarias. La suspensión y la expulsión -aunque hoy en día se siguen aplicando a través de una manipulación corrupta de las reglamentaciones- atentan contra el derecho a la educación, una de las máximas presentes en numerosos tratados internacionales y en la Ley 26.206 de Educación Nacional.
} 
Alumna 2: -Yo le meto una patada en el orto y la dejo una semana sin sentarse.

La situación mencionada en el diálogo no tuvo lugar en el ámbito escolar; sin embargo, consideramos que el fragmento es oportuno porque remite a lo que podría considerarse cierta "irrelevancia" o "desconsideración" de las instancias oficiales previstas para la regulación de la convivencia. A pesar de haber sufrido la agresión de una persona mayor, la joven desacredita la denuncia como medida legal para reclamar justicia. Y eso lo reafirma argumentando que la mujer mencionada ya contaba con varias denuncias previas por causas similares. Ya vimos en el tercer capítulo que el descrédito de las normas tendientes a garantizar una convivencia pacífica constituye un serio riesgo al momento de estar junto con otros, y que ningún marco normativo pude sobrevivir a la sustitución de reglas generales por otras de carácter individual. Dirigiendo la mirada en el ámbito educativo, consideramos que hoy resulta fundamental reafirmar el lugar del acuerdo y el consenso como estrategias ordenadoras a la hora de resolver conflictos de cualquier naturaleza.

Centrando la atención en el interior de las instituciones educativas seleccionadas, el relato de varios adultos no solo da cuenta de la irrelevancia de las normas, sino que en ocasiones también evidencia una desacreditación explícita de las mismas:

Los directivos toman el reglamento como ellos quieren. Hay algunos que se juegan y otros que no (preceptor, "escuela del barrio ferroviario").

Para nosotros es importante que los Acuerdos Institucionales de Convivencia funcionen, supuestamente acá ya hay acuerdos pero... creo que se hicieron hace dos años atrás ¿no? [...] Cuando le preguntamos a los chicos no tenían idea de los acuerdos. [...] Y lo ideal de los acuerdos es que participen también las familias y toda la comunidad educativa. Por ahí eso es lo más difícil. Pero bueno, deberían ser trabajados asî" (integrante del Equipo de Orientación Escolar de la "escuela de la periferia norte").

A fin de evitar generalizaciones, en este punto es necesario aclarar que, si bien en las escuelas relevadas no pudo evidenciarse (al menos en la voz de los adultos) un funcionamiento claro de los Acuerdos Institucionales de Convivencia, no se desconoce el hecho de que en otras instituciones del mismo nivel y gestión estos acuerdos no solo se hallan contemplados desde un punto de vista "oficial", sino que además operan, efectivamente, como consensos constituidos por los diversos agentes escolares. En este punto se destaca el testimonio de una vicedirectora quien, a modo de excepción, hizo referencia al funcionamiento de los acuerdos con cierta coherencia y apegándose a la normativa original: 
Si se trabaja con la familia, si se trabaja con los alumnos, las cosas tienen que volver a su cauce; además todos tienen que ver que uno se preocupa por ellos, que habla con ellos y que si se tiene que aplicar una sanción se aplica. Está en nuestro acuerdo de convivencia, donde dice que nosotros tenemos faltas leves y faltas graves. Esas faltas tienen diferentes tipos de sanción. Esa sanción puede ser una suspensión de dos días y también puede ser que si un alumno tiene reiteradas sanciones se forme un consejo de convivencia (vicedirectora, "escuela del centro").

\subsection{3) Alteración}

Una de las irregularidades que pueden rastrearse a partir del análisis de los testimonios obtenidos en las entrevistas se centra en la manipulación o alteración de las normas existentes. Esta apropiación intencionada de los reglamentos evidencia la falta de supervisión o de seguimiento en lo que refiere a la aplicación de los mismos. El estado considera que la emisión de textos es suficiente, pero en la cotidianeidad escolar estos documentos son reinterpretados con un arbitrio y una parcialidad considerables.

En lugar de atender a la información provista por los documentos destinados al ordenamiento de la convivencia escolar y la resolución de conflictos, muchos docentes, autoridades y miembros de Equipo de Orientación Escolar optan por introducir sus propias leyes o por modificar radicalmente las existentes. Esta discrepancia entre lo que se escribe y lo que se hace, lejos de tratarse de un asunto sin importancia, constituye una irregularidad que influye de manera determinante en el problema de la violencia, ya que no existe algo así como un código reconocido, consultado y aceptado por todos los actores escolares.

La falta de acuerdos claros promueve la libre interpretación de las normas, iniciando un interminable ciclo de intervenciones tendenciosas y considerablemente subjetivas, las cuales, en lugar de mitigar los conflictos, desencadenan otros nuevos. Como afirma Osorio: “existe la ley jurídica, pero no un sistema judicial que la aplique correctamente. Hay caudillos, dictadores y hasta monarcas disfrazados de presidentes. En fin, personajes que no pretenden ser representantes de la ley, sino ser ellos mismos la ley" (2006: 120). Centrando la atención en el ámbito escolar secundario, Dussel ofrece una interesante lectura sobre las dificultades que se suscitan a la hora de intentar "decir" la ley en estos ámbitos:

Es común escuchar que la dificultad de enunciar o instaurar la ley se vincula con la masificación de la escuela media y el acceso de sectores de la población con otros códigos y disposiciones a las habituales en los alumnos de la escuela media. "Los hijos de los salvajes" de hoy son, muchas veces, objeto de prácticas expulsivas por parte de los adultos en la escuela que no saben o no pueden instaurar otros órdenes normativos (2005: 1113). 
La interpretación y aplicación tendenciosa de las reglas -la irregularidad en el funcionamiento de los Acuerdos Institucionales de Convivencia constituye el ejemplo más representativo- también representa en cierto modo una desconsideración a su función ordenadora. $^{85} \mathrm{Al}$ igual que la ya desarrollada "autorregulación juvenil", el manejo intencionado que los adultos hacen de las normativas, también supone el ejercicio de una peligrosa autonomía que en ocasiones converge en la toma de medidas autoritarias y excluyentes. Y esto es posible únicamente con la legitimación generalizada de la ilegalidad, es decir, con la aprobación de la mayoría. En un estudio enfocado en el análisis de los Acuerdos Institucionales de Convivencia, Dussel advierte que los usos tendenciosos de la ley escolar (por parte de los adultos) son una constante que puede evidenciarse en un número considerable de documentos. La construcción y el sostenimiento de una ley asimétrica, diferenciada, estratificada, revela la transposición de ciertas costumbres políticas tendenciosas y cuestionables:

La ley es asunto de los débiles y no de los poderosos, porque quienes pueden, la sortean mediante conexiones o sobornos. [...] La no inclusión de los adultos en la ley escolar, lejos de fundar una asimetría necesaria para la tarea pedagógica (que en todo caso sería deseable fundar en una legitimidad cultural y ética democrática) refuerza la idea de que sólo los débiles son objeto de regulación normativa (Dussel, 2005: 1114).

Así, lejos de tratarse de un asunto que concierne exclusivamente a los jóvenes, la autorregulación de los adultos es un hecho que -por otros mecanismos- promueve el desencadenamiento de hechos violentos; quizás no de forma directa, pero sí por medio de decisiones arbitrarias implementadas al margen o manipulando los reglamentos vigentes. Algunos relatos de los adultos entrevistados dan cuenta lo recién desarrollado:

La escuela tiene que ser apolítica y educar para la paz. Por eso nosotros estamos atentos a todos los brotes posibles de violencia. Nosotros tenemos que escanear el humor del grupo y estar muy encima; desgraciadamente a mí me sirvió lo que aprendí en el sistema carcelario.

Como nunca... una vez tuvimos tres peleas seguidas en el aula a las trompadas en las que se dieron bastante [...]; cuando me metí yo la ligué de costado. Lo peor que hay es meterse, pero hay preceptoras que están muy prácticas en las peleas. Me gustaría que hables con mi compañera. Ella tiene una cancha espectacular. Primero da trompadas y los empuja de atrás y de costado -y además esquiva- ¡vos tenés que ver! Por la experiencia que tiene es una peleadora ideal para contener situaciones de violencia que no pasan de las

\footnotetext{
${ }^{85}$ En la mayoría de las instituciones seleccionadas es posible leer el contenido de los acuerdos de convivencia en afiches pegados en sus paredes. No obstante, su presencia pareciera no tener demasiado valor simbólico. Al respecto Southwell sostiene: "resultaría importante para las escuelas revisar el sentido de ciertas normas y de su posterior exigencia, ya que estas contradicciones entre exigir por un lado pero hacer la "vista gorda" por otro parecen generar vínculos confusos respecto de la legalidad y de la norma (Southwell y otros, 2015: 321).
} 
trompadas. Por suerte son solo problemas de liderazgo, son comunes, son frecuentes, en qué escuela no los hay (profesor en Construcción de la Ciudadanía, "escuela del centro").

A veces empiezo siendo un poquito agresiva con los chicos y después los empezás a conocer... ves que los querés, y no los podés tratar mal (preceptora, "escuela de la periferia norte").

Al anteponer el arbitrio y la imparcialidad, muchos educadores no solo ejercen una autoridad debatible en términos éticos, sino que también operan como reproductores y magnificadores del problema de la violencia; la desregulación generalizada se convierte entonces en un problema que trasciende las distancias generacionales. La ausencia de referencias claras y medidas de sencilla -y coherente- aplicación introduce la incertidumbre y la espontaneidad como prácticas habituales a la hora de determinar qué hacer frente a un hecho "violento".

Lejos de evidenciar una política consensuada y determinada a acabar con los problemas vinculados a la violencia en las escuelas, la omisión y la desregulación que caracterizan a los documentos emitidos por el estado dejan sin efecto el abordaje de la problemática. En este sentido, "uno de los índices de la ineficacia simbólica del Estadonación es, precisamente, la incapacidad para producir instancias adecuadas y legítimas de enunciación y ejercicio de la ley" (Duschatzky y Corea, 2013: 98).

La problemática de la violencia es reconocida por el estado en todos sus niveles (legislatura, ministerios, jefaturas distritales, facultades, escuelas, etcétera), y no faltan normativas pensadas por cada una de estas instancias para hacer frente a esta cuestión; pese a esto, y teniendo en cuenta la información brindada por los informantes, pareciera que la forma en que tales normativas suelen ser implementadas queda supeditada al criterio y a la voluntad de la autoridad interviniente. A partir de esto podríamos decir, siendo un poco esquemáticos, que el estado adopta un posicionamiento algo contradictorio. Por un lado se preocupa en sancionar leyes y distribuir documentos destinados a mitigar la violencia (cuyo contenido, en términos generales, es adecuado y conveniente), pero por otro abandona tales documentos a su suerte, desentendiéndose de la aplicación y de la efectividad de los mismos.

Sobre el material documental referido a la violencia en las escuelas, es pertinente atender a la opinión de dos integrantes de un Equipo de Orientación Escolar (con funciones en la "escuela de la periferia norte"):

Yo particularmente creo que si cada docente leyera las comunicaciones que hay... está 
todo, en comunicación está todo escrito. [...] Te dicen hasta cómo abordar una situación en la que se te presenta un alumno con un arma en la escuela. Todo lo que tenés que hacer te lo dice. Y así para cada una de las situaciones, si hay presencia de sustancias tóxicas, etcétera. Está todo escrito en educación; es leer y apropiarte de eso digamos.

Si bien hay una formación que te la da el instituto o la universidad, luego tenés que estar vos ahí y decir: «bueno yo estoy trabajando en educación, me encuentro con jóvenes y me encuentro con problemas que por ahí antes a un docente no le llegaba a los oídos» (de abuso, de maltrato familiar, de una serie de situaciones). [...] Tenés que tratar de buscar información, tratar de asesorarte, de preguntar a los inspectores; hoy todos tenemos acceso al material.

Con una política discutible en materia de relevamiento y supervisión de las leyes, el estado deposita el tratamiento de la violencia en las escuelas en un personal que se manifiesta "superado", "incapacitado" y "saturado de ocupaciones". El resultado es el ejercicio de una simulación a gran escala, en la cual el estado se asegura así mismo el haber tomado medidas en el asunto, incluso cuando es evidente que tales medidas, por sí solas, son insuficientes. En otros términos, pareciera que el estado se contenta con aportar herramientas para la solución del problema, suponiendo que si esas herramientas no son utilizadas (correctamente) será por culpa de los alumnos o los docentes que no actúan de acuerdo al último comunicado.

\subsection{Los efectos nocivos de la burocracia y la "vorágine escolar"}

Para explicar el sentido en el que es entendida la idea de burocracia y su vínculo posible con la cuestión de la violencia, ${ }^{86}$ comenzaré este apartado con el relato de una experiencia personal vivida en el año 2016 en calidad de profesor, a la salida de un colegio secundario (que no forma parte de las instituciones en las que fueron realizadas las entrevistas). En el momento mencionado, en la vereda inmediatamente posterior a la puerta del

\footnotetext{
${ }^{86}$ En este punto, a fin de evitar malos entendidos, consideramos necesario explicitar qué entendemos por burocracia. En pocas palabras, y en línea con una conceptualización arendtiana del término, interpretamos la burocracia como una serie de disposiciones estatales materializadas en un "conjunto de oficinas" y en una serie de roles estratégicamente distribuidos para automatizar y, consecuentemente, despersonalizar las tareas vinculadas a la administración del estado (Arendt, 2006). Si bien no pretendemos hallar en Arendt respuestas a problemas locales, esta breve caracterización de la burocracia adquiere particular relevancia para el desarrollo de este trabajo, dado que el automatismo y la despersonalización que caracterizan el sistema educativo de la Provincia de Buenos Aires en ocasiones operan como un obstáculo que obstruye las posibilidades de acción de sus agentes. Este asunto puede ser leído de dos maneras (posiblemente complementarias): por un lado, podemos presuponer que la burocracia es efectiva y son las personas que ocupan los diversos cargos quienes, por inoperancia o falta de compromiso, alteran su funcionamiento. Desde otra perspectiva, son los agentes educativos, quienes, a pesar de contar con una capacitación y una predisposición acorde a las funciones que desempeñan, se topan con un aparato administrativo que limita sus posibilidades de intervención (en lo que refiere al tratamiento pedagógico de la violencia).
} 
establecimiento (donde se encontraban alumnos, familiares y personal de la escuela), se acercó una madre con lágrimas en los ojos y claros síntomas de angustia, pidiendo hablar urgentemente con algún preceptor o autoridad. Ella solicitó - acongojada- cambiar a su hijo de colegio, quien, según su relato, no aprendía nada a causa de los problemas que protagonizaban "los violentos de la escuela". De acuerdo al testimonio de la madre, toda la atención estaba dirigida a los conflictos que generaba un grupo reducido de alumnos, quienes atentaban, no solo contra su hijo, sino también "contra todo el colegio".

Entre gestos de apuro para que los alumnos desalojen la escuela, una preceptora -en ese momento la única representante del establecimiento en lo concerniente a cuestiones administrativas- se encuentra con la madre y fríamente le responde: "ahora no te puedo atender porque tengo que entrar a la una en otro colegio y no tenés el formulario que tendrías que haber sacado en la fotocopiadora". El hecho concluyó con la madre -ahora más angustiada por la impotencia de ver frustrada su solicitud-y su hijo, solos en la puerta del colegio, sin posibilidad de hacer nada para mejorar su situación.

Los aspectos destacables de la anécdota se centran en que, pese a la presencia de dos adultos responsables por el cuidado y la educación de un joven -aparentemente acosado por sus pares-, fue imposible hacer algo para mejorar la situación del alumno. Lejos de buscar alternativas o programar un encuentro, la "vorágine escolar" y las trabas burocráticas impidieron algo tan básico, necesario e imposible como el diálogo entre una madre y la preceptora de su hijo. Centrando la atención en la cuestión de la burocracia, no podemos pasar por alto el hecho de que, en ocasiones, esta compleja red administrativa no solamente dificulta la tarea de enseñar, sino que también obstaculiza la resolución de diversas problemáticas acontecidas en la escuela.

Es preciso aclarar que el automatismo y la impersonalidad que la burocracia introduce en los ámbitos escolares no suponen el desencadenamiento automático de acontecimientos violentos; la influencia es indirecta. La relación que podría condensarse en la frase "a mayor burocracia, mayor violencia" radica en que la burocracia -inhabilitando la reflexión y la acción de los actores escolares- dificulta y obstaculiza la resolución de los conflictos. En otros términos, podría decirse que el efecto de la burocracia sobre la violencia es magnificador, pero no por mecanismos coactivos sino por la impotencia y la frustración que resultan del "dominio de nadie" (Arendt, 2006). 
La burocracia, la rutina, el desapego, la falta de compromiso y una institucionalidad exigua en términos de contención material y simbólica, promueven la continuidad de un automatismo que impide atender lo que acontece en los colegios, en materia de vínculos, conflictos y convivencia. Siendo un poco esquemáticos, podría decirse que, una vez finalizado el horario escolar, todo es borrón y cuenta nueva: la "vorágine" se lo come todo y los problemas derivados de las relaciones personales solo pueden atenderse si ocurren antes de la una. El sostenimiento de esta inamovible e infranqueable rutina supone -en estrecha relación con lo desarrollado en el segundo capítulo- el ejercicio de una peligrosa indiferencia por parte de los adultos. La omisión de los conflictos y la hipócrita reacción de asombro cuando estos se exteriorizan en el plano físico solo aseguran la perpetuidad y el agravamiento del fenómeno estudiado. Al no recibir la ayuda que la madre estaba solicitando, los problemas del chico pueden haberse agravado, o incluso la propia madre puede haber recurrido a medios más agresivos con el fin de captar la atención de docentes y autoridades, introduciendo de este modo un nuevo conflicto sobre otro irresuelto.

Si bien en el relato de los informantes adultos la cuestión de la burocracia y la "vorágine escolar" no son manifestadas exactamente con la misma denominación, consideramos que el relato de algunas experiencias y sensaciones vividas (por ejemplo, aquellas en las que se hace referencia a funciones mal desempeñadas, la pérdida de sentido de la tarea, o quejas que involucran en algún punto "al sistema") pueden incluirse como testimonios de las categorías propuestas. A continuación citamos algunos ejemplos:

Los padres se quieren comunicar pero la preceptora falta toda la semana, pero durante diez años. Nadie le hace un examen psicológico. Es el sistema. Empezando por el sistema... los profesores, los preceptores, todo el cuerpo educativo no está en condiciones (profesor en Construcción de la Ciudadanía, "escuela del centro").

En el funcionamiento del sistema a veces uno se siente como que es un peoncito. Entonces cuando uno tiene que sacrificar una ficha en la partida de ajedrez ¿qué sacrifica primero? El peoncito. Entonces uno a veces siente eso, que es un poco descartable [...]. Llega un punto donde uno termina siendo cómplice de toda esa burocracia tonta... te ponés a pensar y uno se pelea con los pibes para que no rompan las cosas, cuando lo que tendríamos que hacer es perder tiempo y pelear contra el consejo escolar. Esas son las cosas las que te terminan distorsionando la cabecita (preceptor, "escuela del barrio ferroviario").

Cuando a ellos les pasa algo y el profesor quiere continuar con la clase, en lugar de parar y decir "bueno a ver chicos qué les pasa", y por el contrario los saca y les dice "van para dirección", ellos lo ven como una situación de violencia (miembro del Equipo de Orientación Escolar, "escuela de la periferia norte"). 
Para entender mejor esta asociación -indirecta, desgastante y, en ocasiones, volátilentre la burocracia y la violencia, podemos trazar cierta similitud con las investigaciones desarrolladas por Garriga Zucal referidas a la violencia en la formación de los policías de la Provincia de Buenos Aires. Según el autor, "los policías con los que hemos trabajado ocultan sus prácticas violentas y usan la idea de violencia para impugnar las acciones de otros. Por ejemplo, alegan que son víctimas de la violencia burocrática porque sus salarios son paupérrimos y sus condiciones laborales sumamente riesgosas" (2015: 12). La frustración manifestada por los policías con respecto a sus condiciones laborales (materializada en la percepción del riesgo y en la insuficiencia del salario) constituye un factor sumamente negativo para el desarrollo de sus actividades profesionales. En este marco de descontento laboral, los uniformados introducen la "violencia burocrática" como una forma de designar la relación -percibida como desigual, injusta y abusiva- entre ellos y el estado, o, más exactamente, la administración provincial. Con los pertinentes recaudos teóricos, las condiciones laborales descritas por los policías no distan mucho de las reseñadas por los docentes entrevistados en el marco de la presente investigación. La caracterización del aparato educativo como un sistema que "no se halla en condiciones", la percepción del docente como una figura "descartable" comparable con el lugar que ocupa un "peoncito" en el tablero de ajedrez (es decir, una pieza "sacrificable" y de poca relevancia), la demanda de una mayor presencia de los organismos responsables de administrar recursos, o la mecanización observable en las clases de algunos profesores, representan factores -comúnmente relacionados con la idea de burocracia- tendientes a la indiferencia, al descuido de las responsabilidades laborales $\mathrm{y}$, en ocasiones, a la exacerbación de un clima hostil que termina por naturalizarse.

En Sobre la violencia, Arendt entiende la burocracia "como un complejo sistema de oficinas en donde no cabe hacer responsables a los hombres, ni a pocos ni a muchos y que podría ser adecuadamente definida como el dominio de nadie" (2006: 53). Si bien el análisis propone la autora no se centra en cuestiones específicamente educativas, la hipótesis de que la burocracia comparte algunos elementos con la violencia nos invita a considerar su propuesta. Arendt atribuye a la burocracia un carácter tiránico, ya que al tratarse de un sistema que no está obligado a dar cuentas a nadie (es decir, que antepone la impersonalidad del documento a la persona), "no existe precisamente nadie al que pueda 
preguntarse por lo que se está haciendo" (ibíd.)

En ocasiones, la burocracia ligada al sistema educativo público de la Provincia de Buenos Aires parece funcionar como un obstáculo a la hora de combatir los problemas comúnmente asociados a la violencia. Lejos de tratarse de un asunto irrelevante, esta "mediación impersonal" hace que, tomando como referencia el relato del preceptor citado más arriba, algunos profesionales de la educación opten por eludir sus responsabilidades antes que verse envueltos en situaciones conflictivas. Siguiendo esta línea, sería comprensible -pero no justificable- el hecho de que un educador prefiera, frente a una pelea (por ejemplo), esconderse en lugar de intentar desarticularla.

Cuanto más grande sea la burocratización de la vida pública, mayor será la atracción de la violencia. En una burocracia completamente desarrollada no hay nadie con quien discutir, a quien presentar agravios o sobre quien puedan ejercerse las presiones de poder. La burocracia es la forma de Gobierno en la que todo el mundo está privado de libertad política, del poder de actuar; porque el dominio de Nadie no es la ausencia de dominio, y donde todos carecen igualmente de poder tenemos una tiranía sin tirano (Arendt, 2006: 110).

$\mathrm{Si}$, asumiendo una postura algo ensayística, trasladamos las reflexiones de Arendt al ámbito educativo, podríamos decir que la burocracia, al establecer "el dominio de nadie" y "la imposibilidad de acción", constituye uno de los elementos más agravantes en el asunto de la violencia. A través de la despersonalización, el automatismo y la irreflexión, esta modalidad de administración genera las condiciones propicias para que muchos jóvenes despreocupados de cuestiones operativas, legales y jurisdiccionales- habiten lo que podríamos denominar "vacíos de autoridad", introduciendo allí sus propios códigos, considerablemente más simples aunque -impredecible y riesgosamente- "más físicos".

Es preciso aclarar que el personal adulto no escapa a esta "sustitución de normas": en muchas ocasiones, para no lidiar con los cuantiosos "requisitos burocráticos" varios docentes y autoridades manifestaron haber seguido sus propias reglas (para resolver un hecho comúnmente considerado "violento"). Si bien esto no representa un acto violento en términos físicos, creemos que este tipo de apropiaciones alimentan -aún más- el desconcierto que existe en torno a la problemática en cuestión, ya que, por lo general, las reglas propias suelen ser considerablemente subjetivas (agravando aún más los conflictos existentes o, inclusive, generando otros nuevos). 


\subsection{Intervenciones alternativas}

Siguiendo con el análisis de las intervenciones y retomando la cuestión del lenguaje y su función pacificadora, consideramos preciso citar y analizar una serie de propuestas pedagógicas desarrolladas por Meirieu en Una pedagogía para prevenir la violencia en la enseñanza. ${ }^{87}$ En dicho escrito, el pedagogo pone de relieve una serie de supuestos vinculados a la "violencia escolar" y expone una propuesta basada en cinco factores que, de acuerdo a sus investigaciones en colegios secundarios franceses, servirían para mitigar los hechos comúnmente incluidos bajo este rótulo.

Para la lucha contra la violencia escolar, lo más eficaz es instalar en la enseñanza no la certeza, sino la búsqueda de la precisión, la justicia y la verdad. Esto implica poner en el corazón de la actividad pedagógica algo más que relaciones de fuerza, sobre todo entre alumnos y maestros, y en los alumnos entre sí (Meirieu, 2007: 6-7).

Siguiendo esta propuesta, la primera cuestión a observar en el funcionamiento de una escuela es la relación con el saber. De acuerdo al autor citado, cuando el maestro tiene una relación no dogmática con el saber, es posible advertir cierta disminución de la tensión y la violencia. El pasaje de un docente que reproduce a un docente que investiga abriría las puertas a una tarea de permanente búsqueda alejada de las verdades irrefutables, la repetición, la frustración y la negatividad, elementos que predisponen a los alumnos a permanecer inermes y en un estado de nerviosismo creciente (producto de la exigencia de un único comportamiento válido: acatar y repetir). Según Meirieu: "hemos visto que los docentes en formación continua estaban en situación de búsqueda de una didáctica en sus propias disciplinas y eso pacificaba considerablemente el ambiente de la clase (ibíd:: 7).

Con el eje puesto en la indagación y la exploración de diversos métodos y recursos didácticos, Meirieu introduce un segundo elemento a analizar: el pensamiento experimental. Atendiendo a los postulados del pedagogo, al desarticular la tradicional relación del maestro con el saber, "el mismo alumno se pone en búsqueda de un saber exigente y no coagulado" (ibíd.: 8). Este alejamiento de una verdad indiscutible rompe con la figura del docente como poseedor de un conocimiento esencial, inmutable e irrefutable. Ampliando la hipótesis de Meirieu, podría decirse que la apertura a la búsqueda y a la pesquisa generaría un clima de esfuerzo compartido en el que la violencia no tendría lugar, ya que nadie tendría razones para posicionarse como el único poseedor de la verdad.

\footnotetext{
${ }^{87}$ Es el título de una videoconferencia brindada por Meirieu en el año 2007 en el contexto del Quinto Encuentro de Videoconferencias organizado por el Observatorio Argentino de Violencia en las Escuelas.
} 
Siguiendo esta lógica, nos animamos a afirmar que en el mundo de la investigación no importa quién es el que tiene más fuerza o quién es el que grita más fuerte, lo que verdaderamente importa es acceder a las herramientas que posibilitan establecer una relación dinámica con el saber.

Observamos en las clases que cuando hay tensión, cuando hay violencia, al hacer intervenir el pensamiento experimental, se produce una situación que cobra gran importancia: la violencia de las opiniones se ve regulada por el experimento que los chicos van a tener que hacer (Meirieu, ibíd.: 8-9).

En estrecha relación con lo desarrollado más arriba, el tercer elemento que menciona Meirieu es la búsqueda documentaria. Este ejercicio de ir a las fuentes, confrontarlas y verificar su veracidad posibilita introducir objetos, cosas y temáticas atrayentes para los propios jóvenes. Esta tarea no está ceñida únicamente al programa escolar ni al enciclopedismo tradicional; la investigación de diversas fuentes admite la posibilidad de preguntarse sobre problemáticas contemporáneas y situacionales que afectan directamente a los jóvenes (familia, género, sexualidad, adicciones, trabajo, capacitación, etcétera). Siguiendo a Meirieu: "incluso con alumnos muy duros y muy violentos, en cuanto se los ponía en la situación de búsqueda de información documentaria [...] tenían que salir de la afirmación brutal y entrar en un proceso a través del cual se despegaban del pasaje al acto" (ibíd.: 9).

El cuarto tipo de actividades que deberían observarse en una escuela preocupada por combatir la violencia son las actividades artísticas. El pedagogo en cuestión afirma que "cuanto más arte hay, hay menos violencia, aunque el entorno sea difícil" (Meirieu, ibíd.: 9). El principio que sostiene tal afirmación supone que las actividades artísticas introducen la posibilidad de adentrarse en un orden simbólico que posibilita la expresión de los deseos a través del dibujo, el teatro o la música. Este ejercicio de la simbolización permite que las manifestaciones individuales no sean reprimidas, sino que puedan exteriorizarse a través de prácticas socialmente aceptadas. Esta alternativa, distante de la realidad pero ligada al mismo tiempo a través de su representación, solucionaría dos demandas frecuentes de los jóvenes: por un lado, la necesidad de mostrarse, de decir quiénes son y exponer lo que les sucede en sus vidas, y por otro la posibilidad de hacerlo en un ambiente de trabajo y reconocimiento mutuo.

La expresión artística es tal vez la manera de acceder a esa capacidad mental de percibir lo más peligroso de nosotros mismos y expresarlo de una manera que lo transforme y lo 
ponga a distancia, o sea que lo simbólico permite construir una personalidad apaciguada [...]. Esas actividades pueden ser artes plásticas, teatro, música, coro, danza, expresión artística, etcétera (Meirieu, ibíd.: 9).

Aquí consideramos pertinente hacer mención a la experiencia relatada por una preceptora (con funciones en la "escuela de la periferia norte"), quien -motivada por las numerosas problemáticas que afectaban recurrentemente a los alumnos que asistían a la misma escuela- desarrolló un taller de teatro destinado a los estudiantes que estuvieran interesados en participar, no solo en el aprendizaje de diversas técnicas de actuación, sino también en el armado de los guiones. El contenido de estos talleres se centró en la representación de algunas problemáticas recurrentes en la vida de los jóvenes, tales como la violencia de género, los noviazgos conflictivos, los abusos sexuales, las adicciones, la búsqueda de empleo, el embarazo en la adolescencia, etcétera. Uno de los aspectos relevantes de esta experiencia es que la preceptora no se centró en la recreación de obras "preparadas", sino que incluyó a los alumnos en la selección de los contenidos, lo que resultó en un medio de expresión novedoso y convocante, y que ella misma describe como "un espacio en el que se puede establecer vínculos y charlar las diferencias".

Retomando la propuesta de Meirieu, el quinto elemento para la atenuación de la violencia en contextos escolares es la conformación de un proyecto común que involucre a todos los actores de la institución. Este tipo de iniciativas, ligadas a propósitos culturales, deportivos, humanitarios, etcétera, permite que los alumnos perciban la escuela no solo como una institución dispuesta para la reproducción de determinados saberes, sino como un establecimiento capaz de incluirlos como partícipes activos de un proyecto común, democrático e inclusivo. "Cuando el establecimiento tiene un proyecto fuerte y una idea a la que los alumnos pueden aplicarse, hay una disminución notable de los actos de violencia" (Meirieu, ibíd.: 10).

Lejos de posicionarse en la represión directa y la penalización de las faltas, las acciones propuestas por Meirieu para metabolizar la violencia introducen una novedad con respecto al tratamiento de la problemática, ya que no se concentran en lo que hay que hacer una vez acontecido un episodio considerado "violento", sino que se enfocan en el fortalecimiento de aquellos elementos que posibilitan mejorar el clima de los establecimientos educativos. Reconstruyendo y ampliando su propuesta, podría decirse que la riqueza de su iniciativa pedagógica consiste en que, sin necesidad de apelar a grandes 
reformas o transformaciones, es posible frenar el pasaje automático al acto poniendo el acento en los recursos simbólicos "disponibles" en cada escuela. Por el contrario, al enfrentar la problemática dirigiendo la atención a los acontecimientos violentos ya ocurridos, no se aborda el origen de los conflictos; esta clase de medidas -siempre urgentes y atrasadas- evidencian algo más preocupante: la ausencia de espacios para el diálogo, la expresión y la contención. Siguiendo a Meirieu: "por supuesto que se pueden poner reglamentos y sanciones, pero para bajar la violencia se debe crear un clima en los establecimientos" (ibíd:: 10). Esta mirada centrada en el fortalecimiento de los vínculos y en la prevención -a diferencia de los abordajes pedagógicos tradicionales que tienden a tratar la violencia con más violencia- introduce algo del orden simbólico que sustituye y desalienta por completo el uso de la fuerza. Siguiendo esta línea, los estudios de Kornblit también hacen referencia a la importancia de un clima favorable, la relación docentealumno y la integración de los estudiantes como acciones tendientes a la mitigación de las "situaciones violentas". En sus palabras:

Las conclusiones permiten evidenciar que los climas escolares favorables, en los que se desarrollan prácticas pedagógicas que facilitan la integración y participación de los alumnos, disminuyen considerablemente la frecuencia de situaciones violentas, tanto en lo que respecta al hostigamiento como a las manifestaciones de violencia propiamente dicha (2008: 12).

En las escuelas seleccionadas, varios de los educadores entrevistados demostraron poseer la capacidad creativa de pensar estrategias para mitigar la violencia con los recursos disponibles en sus establecimientos, además, fundamentaron sus propuestas con argumentos no muy distantes a los desarrollados por Meirieu. Dicho de otro modo, cuando se consultó a docentes, autoridades y miembros de los EOE sobre qué aporte consideraban interesante para el tratamiento de la violencia en su escuela, algunos de los profesionales consultados hicieron referencia -con sus propios términos- a la relevancia del orden simbólico, el empleo de la palabra, la moderación de la fuerza, la importancia de la ley, la implementación de actividades artísticas, entre otras medidas pertinentes, novedosas y relativamente ejecutables.

A continuación se citan algunos de los fragmentos que se inscriben en esta “metabolización” o "abordaje pedagógico" de la violencia:

Entonces cuantos más hábitos de convivencia y buenas costumbres, se van a presentar menos situaciones de violencia. En la medida que se vayan generando acuerdos, en la 
media que tanto los adultos como los chicos comprendan que es necesario respetarse, es necesario sociabilizar (Directora, "escuela del barrio ferroviario").

Ahí donde falta la palabra irrumpe el acto, irrumpe la violencia sin sentido. Y ahí es donde -desde nuestra modalidad-decimos que es importante que haya otro que medie eso. Que pueda codificar, traducir, ponerle palabras a esto que le pasa al chico (integrante del Equipo de Orientación Escolar de la "escuela de la periferia norte"). ${ }^{88}$

El primer paso debe ser el diálogo. Tenés que hablar con las personas. Si son los chicos los que se pelean, primero con los chicos. [...] Necesitamos comenzar a hablar de las cosas que nos irritan, que nos hacen mal, que nos ponen mal, y las cosas sobre las que no estamos de acuerdo [...], eso es fundamental en la comunidad educativa (vicedirectora, "escuela de la periferia norte").

Este año muchas personas me dijeron, "bueno, yo los apruebo porque no los quiero ver más. Me los quiero sacar de encima". Yo la verdad los entiendo. Ahora, ¿por qué no mejor nos sentamos en una reunión antes de empezar las clases y planteamos los problemas? [...]. Tiene que haber coherencia en la escuela, una unión entre directivos y entre docentes. Respaldarse, saber que tu compañero va a estar con vos y que el directivo no es tu enemigo, ni que se va a lavar las manos (preceptor, "escuela del barrio ferroviario").

Teniendo en cuenta que algunos de los profesionales consultados -sin importar el título habilitante ni la especificidad de la función- se mostraron capaces de proyectar, al menos en la enunciación, acciones pedagógicas para disminuir el estallido de conflictos violentos, cabe preguntarse por qué estas ideas, incluso cuando son pertinentes y realizables, no son llevadas a cabo. ¿Qué separa a la enunciación de la ejecución, de la experiencia? Estos cuestionamientos nos obligan a remitirnos una vez más al entramado burocrático que caracteriza al sistema educativo público de la Provincia de Buenos de Aires. Este organismo -aun contando con educadores predispuestos a hacer algo para combatir la violencia con los recursos que tienen a su disposición- funciona muchas veces como un impedimento, anteponiendo la burocracia, el automatismo y la despersonalización a cualquier intervención que se aleje de la rutina.

\subsection{Conclusiones parciales}

Los modos en que se suelen resolver los problemas comúnmente asociados a la violencia en las escuelas, por el carácter confuso y arbitrario de las intervenciones, no solo demuestran un alto grado de ineficacia, sino que, en ocasiones, agravan aún más el problema inicial (desencadenando otros nuevos). Esto probablemente se deba en parte a las dificultades y las

\footnotetext{
${ }^{88}$ Cuando hace referencia a la modalidad, se está refiriendo a Psicología.
} 
limitaciones de un sistema educativo altamente burocrático, que antepone el automatismo y la rutina sobre la búsqueda de soluciones efectivas y duraderas.

De acuerdo al testimonio de varios educadores, pareciera que las ideas orientadas a mitigar los problemas comúnmente asociados a la violencia están destinadas a disolverse en la burocracia de un "sistema que te atrapa" (en palabras de un preceptor perteneciente a la "escuela del barrio ferroviario"). Docentes corriendo de una escuela a otra, autoridades abocadas exclusivamente a tareas administrativas, Equipos de Orientación Escolar desbordados de casos, padres ausentes y alumnos desatendidos, hacen imposible la reunión de voluntades para establecer acuerdos.

Resumiendo, además de la influencia de factores histórico-políticos, como la reconfiguración de la autoridad y el debilitamiento del lenguaje, creemos que la forma en que el estado administra las escuelas públicas secundarias en ocasiones dificulta u obstaculiza lo que Meirieu denomina "la lucha contra la violencia escolar" (2007: 6). Sin proyectar reformas ambiciosas e irrealizables, y en línea con el autor recién citado, creemos que en las escuelas medias resulta imperioso generar y reforzar los espacios previstos para el encuentro, el reconocimiento y la negociación. Recordemos que, como señala Arendt (2006), los vínculos humanos constituidos por mecanismos pacíficos suelen ser más sólidos y perdurables que aquellos forzados por medio de la violencia. 


\section{Capítulo 5: El pasaje automático al acto}

Todo parece indicar que la violencia con el otro, la violencia a modo de descarga o pulsión descontrolada es el índice de la incapacidad [...] para instituir una subjetividad regulada por la ley simbólica.

Silvia Duschatzky y Cristina Corea (2013)

\subsection{La acción muda}

A partir del análisis de la información proporcionada por los informantes, de la revisión de bibliografía especializada y de algunas experiencias -de carácter exploratoriasdesarrolladas en el campo de la extensión, ${ }^{89}$ consideramos pertinente recuperar y ampliar uno de los temas tratados de manera incipiente en el tercer capítulo, esto es, la dimensión física de la violencia, junto a lo que podría considerarse su sentido opuesto o alternativa inmaterial, es decir, el uso argumentado de la palabra y la inscripción del cuerpo en un orden simbólico. Analizando -de manera hipotética- los modos posibles en los que podría llevarse a cabo esta tarea de "acercar" el cuerpo a aquellas prácticas socialmente aceptadas, en la última parte del capítulo proponemos adentrarnos, en sintonía con algunas reflexiones de Elias y Dunning (1992), en las posibilidades que ofrecen el juego y el deporte como espacios oportunos para trabajar la renuncia a la violencia. Siguiendo esta línea, centraremos la atención en tres aspectos constitutivos de las prácticas mencionadas: la identificación de los usos del cuerpo legítimos e ilegítimos, la negociación de acuerdos (sobre todo en relación al juego) y el reconocimiento de las reglas.

Ya vimos, a partir del análisis de varios referentes teóricos provenientes de diversos campos académicos (Elias y Dunning, 1992; Arendt, 2006; Lacan, 2010; Le Breton, 2017, entre otros), que toda acción violenta lleva ínsita una exteriorización física. Empleando

\footnotetext{
${ }^{89}$ Las actividades asociadas al trabajo de extensión se enmarcan en el proyecto denominado "Convivencia, lazo social y construcción de legalidades", dirigido por Adriana De Negri y Cristina Erausquin y radicado en la Facultad de Psicología (UNLP). Entre sus propósitos se destacan la elaboración de talleres interdisciplinarios (en escuelas secundarias de La plata, Berisso y Ensenada) en los que se aborda la cuestión de la violencia, la convivencia y los vínculos desde múltiples enfoques. Centrando la atención en las potencialidades que ofrecen los juegos de rol y los juegos cooperativos -dónde el reconocimiento del otro es un requisito fundamental para la práctica-, las experiencias desarrolladas hasta el momento, y el interés demostrado por los alumnos, han creado una veta factible de estudio y ampliación. Si bien aún no se pueden establecer conclusiones con respecto al resultado de este proyecto, el encuentro de los jóvenes con una serie propuestas no convencionales evidenció la imperiosa necesidad que estos tenían de expresar sus descontentos y preocupaciones. Es preciso aclarar que el proyecto no parte de una negación de la violencia; por el contrario, intenta ofrecer espacios alternativos para que los jóvenes puedan expresar sus preocupaciones y sus diferencias sin necesidad de hacer uso de la fuerza física.
} 
Dicho de otro modo, en casi todas aquellas manifestaciones que -tras haber sobrepasado determinados umbrales de tolerancia- pueden ser caracterizadas como "violentas", el cuerpo suele considerarse un objeto simplificado a su costado orgánico, es decir, una materia viva que responde de manera automática ante un estímulo (Crisorio, 2010). Incapaz de acudir a medios "no físicos" para expresar o demandar algo, el cuerpo es reducido a lo que Arendt denominaría la "acción muda". En sus propias palabras: "la violencia, a diferencia del poder, es muda; comienza allí donde acaba el discurso" (2008: 30).

En una pelea, el cuerpo puede amoldarse o convertirse en un instrumento disponible para causar daño a otro objeto igualmente reducido a lo tangible, a lo palpable, y, por ende, a lo destruible. La característica principal de esta reducción instrumental es su escisión con respecto al lenguaje, su alejamiento del orden simbólico que se manifiesta inversamente proporcional a la materialización o a la substanciación física. Agotado el lenguaje, todo pasa por la carne; todo debe sentirse, experimentarse, probarse, la persuasión cede ante la fuerza y las disputas se resuelven al margen de los símbolos, o sea, mediante la superioridad física. A este proceso en el que el cuerpo es concebido como una cosa maleable, destruible y, sobre todo, incapaz de adaptarse a los mecanismos pacíficos de negociación, lo denominaremos, con fines analíticos, como la experimentación del cuerpo mudo.

Si tenemos en cuenta que la civilización se erige sobre la renuncia a la violencia (Elias y Dunning, 1992), el riesgo que todo acto "violento" conlleva -en el que se desconoce o se omite la existencia del otro como semejante- es el debilitamiento o la desarticulación de los lazos sociales. Al anteponer la satisfacción del deseo propio a cualquier precio, es decir, al desatender las consecuencias y los medios empleados para alcanzar un objetivo o demandar algo, la vida en relación con otros se dificulta considerablemente. En pocas palabras, podría decirse que el cuerpo es la materialización del individualismo característico de nuestro tiempo, un individualismo cada vez más tendiente al aislamiento, la autosatisfacción y la destrucción del otro.

En la bibliografía dedicada el estudio de la violencia en las escuelas, el cuerpo es caracterizado frecuentemente como un objeto con el que es posible "experimentar", "materializar" o "pasar al acto", como si se tratarse una cosa tocable y modificable sobre laque los jóvenes pueden plasmar aquello que no pueden manifestar mediante el empleo de 
recursos simbólicos. Para Meirieu, por ejemplo, el problema de la violencia en las escuelas gira en torno al "pasaje sistemático al acto, [...] ya que es un pasaje a la violencia, a veces en términos de agresión física" (2007: 3). Duschatzky y Corea, por su parte, afirman que "la violencia se trata de una expresión que se materializa en el cuerpo" (2013: 25-26); siguiendo esta línea, Kornblit considera que "la vía libre a las experiencias agresivas son el correlato [...] de la imposibilidad de poner en palabras el malestar" (2008: 11), mientras que para Kaplan "la violencia opera en lugar de la palabra" (2015: 20). Se ve así claramente que, para estos autores, el cuerpo se vincula tanto a una dimensión física (lo material, lo moldeable, lo tangible) como a una dimensión biológica (lo instintivo, lo indómito, lo salvaje). Profundizando este análisis, el cuerpo implicado en un acto violento representaría algo así como un depósito donde es posible volcar aquello que no se puede o no se sabe expresar de manera inmaterial. Asimismo, el cuerpo también sería el lugar donde "lo natural" se hace carne. En esta lógica -de la cual pretendemos distanciarnos-, la violencia podría considerarse como una parte "esencial" del hombre, o en otras palabras, como una conducta innata, originalmente empleada -y justificada- para la defensa, el ataque, la supervivencia, etcétera. ${ }^{90}$

\subsection{La tipología física del "violento"}

La violencia entendida como parte esencial del ser humano, como comportamiento inherente a su existencia, suele vincularse con una interpretación marcadamente biológica de la vida. Asociar la violencia con ciertos rasgos físicos, con cierta animalidad latente o con algunas conductas "hereditarias" es una explicación marcadamente tendenciosa y determinista que suele entremezclarse con la noción de agresividad, un concepto

90 En el marco de esta lectura "biologista" o "naturalista", consideramos pertinente mencionar una interpretación que hace Osorio respecto del problema de la violencia en las escuelas, ya que para evidenciar la creciente gravedad del fenómeno, el autor utiliza algunos términos comúnmente empleados en el campo de la biología. En sus propios términos: "los jóvenes irrumpen en la calle y en los colegios con la voracidad de una fiera que sale a cazar. [...] Los tiempos están alterados, los valores extinguidos. Se supone que las nuevas generaciones deberían superar las anteriores. Se involuciona hacia el hombre primitivo. Aunque el hombre primitivo sólo mataba cuando necesitaba proveerse de abrigo y alimento" (2006: 121-122). Consideramos que el empleo de palabras comúnmente ligadas al estudio de la agresividad animal (tales como: "fieras", "caza", "extinción", "involución" y "hombre primitivo") reviste la cuestión de la violencia -no solo en las escuelasde una serie de preconceptos y arbitrariedades tendientes a la tipificación y al recrudecimiento del fenómeno: si el comportamiento de un alumno puede ser reducido o comparado al de un animal, resulta muy difícil, sino imposible, pensar estrategias de intervención más allá de las comúnmente empleadas en el mundo de la biología. En contraposición, creemos que, por motivos ya descritos en los capítulos precedentes, el problema de la violencia remite exclusivamente al orden de lo social. 
comúnmente empleado en el estudio de otras especies (Patierno, 2018a). En contraposición, podríamos considerar que los animales no son violentos ni agresivos, y que estos sencillamente se comportan de acuerdo a sus instintos. Recordemos la afirmación de Arendt: "la violencia ni es bestial ni es irracional" (2006: 84). Esta aclaración se hace fundamental para distanciarse de las explicaciones provenientes de la biología, la fisiología y la zoología, las cuales pretenden atribuir al humano cierta violencia o agresividad caracterizada a partir del estudio de otras especies. La autora citada nos ofrece algunas claves para entender mejor los efectos de estas tendencias "biologistas" sobre los comportamientos humanos. En sus propios términos: "no creo que necesitásemos conocer los instintos del «territorialismo de grupo» de las hormigas, los peces y los monos; para conocer que el hacinamiento origina irritación y agresividad" (ibíd.: 79-80).

En contextos escolares, recalcamos la presencia (al menos en las escuelas relevadas) de ciertos discursos tendientes a atribuir una serie de conductas comúnmente consideradas violentas, delictivas o vandálicas con determinados rasgos físicos. Así, fue posible advertir que, si bien constituyen una minoría en relación a la totalidad de la muestra, algunos educadores aún sostienen un discurso que reproduce en cierto modo las teorías lombrosianas de la delincuencia, en el que se presume que los jóvenes, y, más particularmente, aquellos cuya "apariencia" puede vincularse a sectores vulnerables, son más proclives a cometer actos ilícitos (robo, agresión, narcotráfico, pillaje, etc.). En línea con lo recién desarrollado, seleccionamos un fragmento de las entrevistas realizadas a los adultos:

Una alumna se peleó con una compañera y fue tan mala, tan mala -y eso que eran íntimas amigas-, cuestión que la empujó para que la pisara un auto, ¡la empujó en la calle de la escuela para que la matara un auto! [...] Si ves a la chica, es una rubia, una modelo, no puede haber hecho eso, sin embargo tuvo toda la intención de quitarle la vida (profesor de Construcción de la Ciudadanía, "escuela del centro").

En el relato podemos advertir que el profesor asocia -de manera automática- lo que él considera violencia con cierta representación de apariencia o caracterización física. Si bien no describe específicamente los detalles del estereotipo "violento", sí nos ofrece pistas a partir de la descripción de su opuesto, es decir, del tipo de personas que él considera excluidas o alejadas del "ideal violento" (además de la mención a la "maldad" como un comportamiento evidente y atribuible a una persona). Para llevar a cabo la distinción entre el "ideal violento" y su opuesto, emplea tres palabras claves: "chica", "rubia y "modelo", 
no casualmente tres de los principales rasgos físicos asociados al estereotipo occidental de belleza femenina (y alejados de la representación social del "violento", el "delincuente" o el "pibe chorro").

Las investigaciones de Garriga Zucal, plasmadas en el libro El inadmisible encanto de la violencia, nos sirven para reflexionar acerca de los señalamientos y las estigmatizaciones que suelen envolver la caracterización del sujeto "violento":

Debemos escapar a la "naturalización" de la violencia ya que los actores sociales tienen múltiples pertenencias sociales. Así, un mismo actor puede estar inserto en una trama relacional que impugne prácticas que él considere violentas y, al mismo tiempo, sea parte de acciones que otros consideran como violentas. La violencia no es una particularidad natural ni esencial de ningún grupo social. Desde esta perspectiva, podemos escapar de un error recurrente: transformar a los que cometen acciones violentas, de una vez y para siempre, en violentos (2015: 14).

Desde el punto de vista de los alumnos entrevistados, la situación no dista mucho de la descripta anteriormente. Si bien emplean otros términos, tales como "villero", "chorrito", "cara de captura" o "cara de secuestro", la caracterización del "violento" generalmente coincide con cierta imagen social creada en torno a la representación del delincuente juvenil. En línea con lo recién desarrollado, debemos tener en cuenta que el mismo discurso por el que se presume que el sujeto "violento" o el delincuente puede ser identificado como tal por su "cara", su "forma de ser" o su "manera de vestir", también sirve como fundamento para graduar la severidad de los castigos "merecidos". En una investigación anterior (Patierno, 2014), cuando se consultó a los alumnos sobre la naturaleza y la determinación en el tipo de sanciones que deberían recaer sobre un sujeto señalado como "violento", a diferencia de las medidas comúnmente aplicadas por los adultos, estos introdujeron sin resquemores el castigo físico y la exclusión social como penas perfectamente admisibles.

Aquí debemos hacer una pausa para reflexionar acerca de los riesgos que conlleva la reproducción irreflexiva de ciertos discursos tendientes al señalamiento y a la discriminación. Adjetivar a un sujeto o a un grupo bajo el rótulo de "violento" no es un acto neutral, sino que, de acuerdo con Kaplan, "establece distancias entre unos y otros y tiene consecuencias sobre la mirada que ese sujeto construye de sí mismo" (2009: 20). Cuando este tipo de señalamientos acontece de manera frecuente en el ámbito escolar (incluso a través de mecanismos involuntarios), nos encontramos frente a la propagación de un discurso fuertemente estigmatizador con el cual se estaría tipificando y atribuyendo 
caracteres -justificados en una serie de prejuicios y en la reproducción de cierta paranoia social- a aquellos jóvenes que, sin importar los motivos, se asemejan o se acercan a la imagen -socialmente expandida- del "violento", del "chorro" o del "criminal". En una investigación desarrollada por Noel (2006) sobre el conflicto y la violencia en escuelas de barrios populares, el autor sugiere:

Si partimos de pensar que los jóvenes (o aún los niños) son violentos, de que los sectores populares son particularmente propensos a la violencia, y de que, en consecuencia, las escuelas de sectores populares serán inevitablemente violentas, habrá de configurarse un marco de interpretación en el cual casi cualquier cosa que hagan los chicos o sus padres será leído como violencia, mientras que conductas o hechos similares en otras escuelas no recibirían la misma calificación (2006: 42).

Como se dijo en el primer capítulo, la personificación de la violencia es una práctica cuyos orígenes se remontan al siglo XIX, cuando se pensaba que determinados rasgos corporales constituían prueba suficiente para excluir u ocultar al sector de la población que se alejara del modelo de "ciudadano ideal". En el ejemplo que menciona Noel se ve cómo, en determinadas escuelas ubicadas en barrios "exclusivos" o "privilegiados", una acción como puede ser tomar el útil escolar de un compañero- puede ser considerada una "travesura" o un juego, mientras que en otras escuelas, situadas en contextos más vulnerables, la misma acción puede ser considerada un acto criminal.

A partir de lo expuesto, consideramos preciso recalcar que no creemos en la existencia de una "naturaleza violenta" ni de cualquier mecanismo que opere como un indicador "incuestionable" para identificar tal cualidad. De acuerdo con Garriga Zucal, "definir prácticas y actores como violentos es una manipulación que ilumina las acciones" (2015: 12-12). La violencia no es observable, más bien se trata de un proceso de adjetivación o calificación -asentado sobre construcciones históricas y políticas- que sirve para señalar aquellos comportamientos que, por su contenido físico y destructivo, son rechazados -y reprimidos- por las instituciones sociales tradicionales.

\section{3 "Nos peleamos porque sí"}

Si bien la permanencia de preconceptos y arbitrariedades no hace más que recrudecer el problema de la violencia, no podemos obviar el hecho de que, atendiendo a la información provista por la bibliografía especializada, pero también al relato de los jóvenes que asisten a las escuelas seleccionadas, es posible advertir que estos evidencian serias dificultades a la 
hora de expresar, mediante recursos simbólicos, sus deseos, demandas y diferencias. Las opciones más recurrentes a la hora resolver sus discrepancias suelen girar en torno a "agarrase a piñas"; "agarrarse a patadas" o "cagarse a trompadas" (en sus propios términos). En esta línea, varios autores recalcan el hecho de que en ocasiones -cada vez más recurrentes- las manifestaciones comúnmente concebidas como "acciones violentas" han sobrepasado umbrales nunca antes superados en este tipo de instituciones. Como apunta Bleichmar (2008), antes era inexplicable que en el sistema educativo de Argentina aconteciera algo como lo que ocurrió en Carmen de Patagones; o que un chico llevara un arma a la escuela, o intentara golpear a un adulto; o que una madre pretendiera agredir a un docente.

A continuación seleccionamos tres testimonios de los estudiantes, representativos de esta tendencia a actuar anteponiendo el cuerpo en su dimensión física:

Yo antes iba a otra escuela y me tuve que cambiar porque siempre nos peleábamos en la parte de atrás de la escuela. [...] Nos peleamos porque sí, porque me miraban mal y me decían cosas y yo me defendía... me hacía respetar (alumno, "escuela del centro").

Yo no puedo hablar con las bolivianas porque a veces te pegan por ser linda nada más [...], porque son bolivianas y nosotras somos blancas. Se enojan porque nosotros somos más lindas (alumna, "escuela de la periferia norte").

Ahora hay más droga. Acá entra mucha, se consigue rápido y encima están las barras bravas de [un equipo de fútbol local] ${ }^{91}$ que tienen la cabida con los del barrio así que ellos manejan todo el negocio de las flores [...]. Igual por un porro no van a salir a robar, ahí está la cocaína. Ahí sí, se toman una línea y los pibes no entienden nada. También le dan a la bolsa. Cuando tienen plata se la re deliran, con lo que trabajan compran droga y para las fiestas consiguen pepas (alumna, "escuela del barrio ferroviario").

Recordemos que, como afirmamos a partir de los testimonios sistematizados en el primer capítulo, las situaciones que los estudiantes suelen identificar como violentas giran en torno a la defensa, un cruce de miradas, los celos, la envidia, la nacionalidad de origen, o como respuesta a una serie de actitudes estereotipadas, tales como "hacerse el gato", "mirar mal", "mirar corte piola", "hacerse el cheto", "hacerse la linda" o "hacerse la popu". Estos motivos suelen encender la chispa del pasaje automático al acto, es decir, una reacción de carácter impulsiva y primaria -aunque no irracional- en la que el otro es reducido a un objeto que colisiona con la satisfacción del propio deseo y, por lo tanto, sería mejor inhabilitarlo o destruirlo (Lacan, 2010).

\footnotetext{
${ }^{91}$ Para preservar el anonimato de los informantes, preferimos omitir el verdadero nombre del club de fútbol.
} 
En los relatos citados más arriba, es posible entrever que el cuerpo es percibido como un objeto material siempre disponible para depositar o exteriorizar -en la piel, en la carne- las dificultades comúnmente asociadas al momento de la vida en que los jóvenes transitan por la escuela. Sea por la demanda -o imposición- de respeto, por la práctica de cierta xenofobia o por el consumo de sustancias tóxicas, el cuerpo siempre aparece ligado al goce de la experimentación directa, a la prueba "en carne propia", al desafío de "ir más allá". El problema de esta materialización o "fisicalización", particularmente en relación al acto violento, es que este tipo de acciones posee un contenido destructivo, y anula la posibilidad de generar y sostener lazos sociales en torno al lenguaje. Parafraseando a Lacan (ibíd.), la violencia es una imposición real, omnipotente y egoísta, llevada a cabo por un agente que se conduce como si no reconociera la presencia de una autoridad legítima, simbólica, mediadora. Al no expresarse como demanda articulada -a través de la palabra-, el acto violento involucra el cuerpo en tanto vehículo de un impulso, una reacción, lo que tiene por consecuencia la provocación del dolor.

Desde el punto de vista de los adultos entrevistados, los actos protagonizados por los jóvenes suelen remitir a lo corporal en tanto cosa física de carácter reaccionario, primitivo e incivilizado; un modo de exteriorización que pareciera inversamente proporcional al uso de la palabra. Dicho de otro modo, el problema de la violencia suele aparecer como una consecuencia de la falta de diálogo (además de la mención recurrente a factores agravantes, tales como la influencia negativa del "barrio", los noviazgos conflictivos, las provocaciones por redes sociales, el alcoholismo y la drogadicción). Para los docentes y directivos entrevistados, los estudiantes "antes de hablar ya se agarraron a trompadas", "no saben resolver las cosas con las palabras", "el profesor los quiere hacer hablar pero no encuentra el modo", "necesitan descargar enseguida con sus manos". 92 A riesgo de generalizar, consideramos que este desuso o debilitamiento del lenguaje, advertido por la mayoría de los profesionales de la educación entrevistados, es el principal factor para el proceso que Meirieu ha identificado como una de las principales problemáticas educativas de estos tiempos, "el pasaje automático al acto" (2007: 3). En este escenario de escasez de diálogo y abundancia "física", el cuerpo pareciera escindido del

\footnotetext{
${ }^{92}$ No se menciona el rol ni la pertenencia institucional de los sujetos entrevistados, ya que estos breves pasajes fueron extraídos de otros ya citados anteriormente (referenciados apropiadamente).
} 
orden simbólico, como si quedara al margen o excedido en relación aquellos usos considerados legítimos o enmarcados dentro de lo que Elias llamaría "umbrales de tolerancia aceptables" (1992: 202). Dicho de otro modo, podría decirse que, desde el punto de vista de los adultos, muchos jóvenes no saben o no pueden acomodar su cuerpo dentro de los parámetros socialmente aceptados, y entonces se ven tentados a alcanzar sus objetivos o resolver sus discrepancias a través de manifestaciones que pueden ser interpretadas $-\mathrm{y}$ tendenciosamente señaladas- como acciones violentas.

\subsection{Nuevas prácticas, nuevos desafíos}

Frente a la reconfiguración de la autoridad escolar, el debilitamiento del lenguaje y la materialización del cuerpo, los educadores nos encontramos frente a una tarea y a una responsabilidad inmensa: proveer a los jóvenes de herramientas simbólicas capaces de suplantar la "fisicalización": no todo tiene que pasar por la piel y por la carne, no todo tiene que sentirse, que hacerse, que vivenciarse. La velocidad extrema, el consumo abusivo de alcohol y de drogas, las perforaciones, los tatuajes, las peleas, la portación de armas, los juegos potencialmente mortales como la "ruleta rusa" marcan tendencia en las redes sociales, ${ }^{94}$ constituyen prácticas que revelan la presencia de un cuerpo mudo, algo así como una forma de transcurrir la juventud en la que se antepone la experiencia como premisa fundamental. ${ }^{95}$ Como advierte Le Breton, "en nuestras propias sociedades individualistas, quienquiera que no se reconozca en su existencia puede intervenir sobre su piel para cincelarla de otra manera" (2017: 51).

\footnotetext{
${ }^{93}$ La ruleta rusa es un juego de azar potencialmente mortal en el que se coloca una bala en el tambor de un revólver, se gira el cilindro y se aprieta el gatillo. El objetivo por lo general es ganar una apuesta o simplemente sobrevivir.

94 Entre los desafíos mencionados se destacan el "knock out", reto que consiste en acertarle un golpe a un transeúnte desprevenido; el "fire challenge", rociarse el cuerpo con algún combustible inflamable, prenderse fuego, e inmediatamente rociarse agua; o la "ballena azul", que consiste en lacerarse el antebrazo formando el contorno de una ballena. En los tres casos mencionados, la secuencia siempre debe ser filmada para, una vez concretado el desafío, difundirlo a través de las redes sociales.

95 Entre las conductas de riesgo consideramos oportuno incluir a los comúnmente denominados "deportes extremos". Para Crisorio, este tipo de actividades ostenta un alto grado de aislamiento y de exposición corporal en el que se ponen en juego un riesgo y una habilidad puramente físicos. "En esos juegos, las únicas relaciones de los practicantes parecen ser consigo mismos, el peligro y la espectacularidad. La palabra con que se suele explicarlos es «adrenalina», es decir, una referencia estrictamente orgánica" (2010: 195). Este tipo de prácticas pareciera comprimir el cuerpo a su costado exclusivamente biológico; los desbordes y los "peligros" se fusionan con una sobrevaloración de "lo físico" y con una resignificación de la idea de riesgo (entremezclada con la noción de desafío).
} 
El placer asociado a la estimulación orgánica no solo implica un riesgo para la propia vida, sino también para la vida en sociedad; esto es particularmente evidente en el caso de la violencia. El uso abusivo de la fuerza no solo representa un peligro para la persona que decide emplear este recurso, sino también un riesgo aun mayor para el contexto en el que se encuentra. Ahora bien, el paso de la exteriorización a la representación, como vimos con Lacan (2010) en su particular concepción de la agresividad, no se trata de una tarea sencilla. Este movimiento requiere de un minucioso y sostenido trabajo de adaptación y readaptación constante en el que los niños progresivamente van reconociendo la existencia de un orden simbólico. La educación en términos generales, y la educación del cuerpo en particular, tienen mucho para aportar en este proceso: el desafío consiste en dotar al cuerpo de cultura, inscribir el cuerpo en un orden simbólico o, desde otro enfoque, deponer los comportamientos imprudentes, egoístas y materiales en favor de una convivencia pacífica construida en torno al empleo argumentado de la palabra y el uso legítimo del cuerpo.

De la multiplicidad de contenidos educativos que podrían considerarse esenciales para el desarrollo de "lo simbólico en el cuerpo", dos de ellos, interpretados en la línea que proponen Elias y Dunning (1992), se presentan como particularmente relevantes: el juego y el deporte. ${ }^{96}$ Estas prácticas representativas, miméticas, alegóricas, constituyen alternativas simbólicas con un altísimo valor educativo en términos de socialización, ya que suelen constituir el primer acercamiento de los jóvenes a los usos del cuerpo considerados legítimos.

En línea con la propuesta de Meirieu (2007) de metabolizar la violencia para que poco a poco su uso sea innecesario y para que el pasaje automático al acto pueda ser redireccionado, consideramos que el juego y el deporte constituyen espacios oportunos para introducir a los jóvenes en un camino hacia el reconocimiento de un cuerpo no necesariamente reductible a lo físico, o, dicho de otro modo, un cuerpo capaz de

\footnotetext{
${ }^{96}$ Aquí es preciso abrir un paréntesis para comentar brevemente por qué hemos decidido introducir la cuestión del juego y el deporte en un trabajo dedicado al estudio de la violencia en las escuelas. Resumiendo, los motivos son dos: en primer lugar, consideramos que las prácticas mencionadas constituyen espacios y momentos oportunos para articular la educación del cuerpo y el acercamiento a un orden simbólico. En segundo término, el análisis de las prácticas mencionadas y su vinculación con el problema de la violencia fue un tema trabajado de manera incipiente en el marco de la realización de la Maestría en Educación Corporal (UNLP). Los alcances parciales de esas indagaciones -de carácter exploratorias- fueron publicados en diversos trabajos académicos; esto nos permite contar con un volumen considerable de información, empleada en este capítulo como antecedente relevante.
} 
"acercarse" a la cultura a través de prácticas mediadas -y reguladas- por mecanismos simbólicos.

\subsection{El juego: la relevancia de la negociación y la pautación de reglas}

Como el juego posee un excelente potencial como estrategia de intervención pacificadora -pasando por alto la discusión acerca de si el "juego-intervención” es específicamente juego-, consideramos que esta práctica es ineludible en el camino hacia el reconocimiento del otro, la negociación, el consenso y la aceptación de las reglas. Si bien el juego suele emplearse como recurso didáctico en los niveles más básicos del sistema educativo, creemos que esta práctica debería trascender considerablemente tal reduccionismo. Ahora bien: ¿qué entendemos por juego? La definición que ofrece Crisorio es teóricamente pertinente:

Nuestra valoración de los juegos no significa [...] concebirlos como conductas innatas que todos los niños poseerían en sí mismos como instrumentos naturales de adaptación al mundo, sino como elementos culturales, cuya transmisión puede contribuir a formar ciudadanos más lúdicos; menos habituados a ser restringidos principalmente por controles externos y más propensos a construir con el mundo una relación menos instrumental; a jugar los juegos institucionales; a ver en los otros algo más que objetos del propio beneficio (2010: 197).

La inclusión de un contenido lúdico disuelve las diferencias personales y en su lugar introduce un objetivo común: desafíos tales como alcanzar una meta, recrear una escena, reunir elementos, plantear estrategias, superar obstáculos, hallar objetos, constituyen una invitación a trabajar mancomunadamente para superarlos. La conjetura que aquí se sostiene es que a través del juego es posible establecer lazos sociales y reconocer la función de las reglas, todo esto en el marco de actividades no convencionales (pensando en la escuela secundaria); asimismo, el uso abusivo de la fuerza aquí no supone ninguna ventaja, por el contrario su empleo representa la automática anulación de la práctica. Como argumento adicional, el carácter mimético que hace al juego (más particularmente los juegos de rol) posibilita la creación de espacios para la expresión y la reflexión en relación a problemáticas relevantes para los jóvenes y la institución escolar.

Sin embargo, en el nivel secundario el juego no cuenta con un espacio y un momento propios, sino que suele reducirse al desarrollo de habilidades requeridas para la práctica deportiva. Este carácter instrumental se encuentra íntimamente vinculado con la permanencia de cierta reticencia a la presencia del juego en la adolescencia y la adultez. 
Muy sintéticamente, la causa de este rechazo se retrotrae al creciente protagonismo de las actividades productivas en las sociedades modernas. Poco a poco, el juego es caracterizado como algo infantil, ocioso, y fundamentalmente opuesto al trabajo. Entre los cambios asociados a la inserción en la vida adulta, alejarse del juego constituye un requisito fundamental para no quedar excluido de la tendencia que asume la mayoría. En esta lógica, el juego es considerado como una práctica inútil, admitida únicamente en la infancia y cuyo sentido es tolerado siempre y cuando colabore en la transición hacia las "ocupaciones serias" (Nella, 2009).

El juego es visto por el pensamiento racional propio de la modernidad como una mera broma, un modo de experimentar la ficción, o, en pocas palabras, como una mentira. En términos de Milstein y Mendes:

Los adultos están regulados por juicios de valor que tienden a distinguir ciertas actividades que designan como [...] apropiadas, descalificando los que se apartan de esa convención como manifestación de un rasgo infantil, inmaduro, lo que supone un menoscabo de su propia condición de adulto. En estos casos, expresiones tales como niñerías, chiquilinadas, etc., revelan la carga de significado peyorativo asociadas al juego (1999: 60).

Si bien esta herencia representa un obstáculo en términos de búsqueda e innovación de estrategias asociadas al juego, también representa una oportunidad para explorar nuevas propuestas tendientes a movilizar recursos y potencialidades comúnmente estancadas en rutinas escolares convencionales. En contraposición a la caracterización negativa que suele envolver al juego en la adolescencia y la adultez, Elias y Dunning (1992) advierten que el juego y las actividades recreativas constituyen parámetros altos de civilización. ${ }^{97}$ En esta lógica, la presencia del juego en las sociedades contemporáneas constituiría la evidencia de haber alcanzado cierto crecimiento o madurez, ya que la posibilidad de jugar solo es admitida una vez resueltas las necesidades básicas que ubican al trabajo en lo más alto de la escala social. En un sentido inverso, los países más pobres y con mayores necesidades económicas son incapaces de admitir el juego como una actividad legítima, ya que malgasta energías y recursos que deberían invertirse en el crecimiento económico.

\footnotetext{
97 Kantarovich, Kaplan y Orce resumen las características generales del proceso civilizatorio como "la monopolización de la violencia y la consolidación de los órganos centrales de poder. La división creciente de funciones y las interdependencias cada vez más amplias sobre masas humanas en espacios territoriales significativamente mayores que en el pasado" (2015: 57).
} 
Una vez resueltas las exigencias socio-económicas, el acercamiento al juego es sinónimo de haber alcanzado un alto grado de desarrollo. En palabras de Elias y Dunning:

En las sociedades-Estado altamente organizadas de nuestro tiempo, con una ubicua presión de controles externos e internos relativamente permanentes, la satisfacción del ocio -o la falta de ella- puede resultar más importante para el bienestar de la gente, desde el punto de vista tanto individual como social, que lo que el valor relativamente bajo adjudicado hasta ahora al ocio nos haría creer (1992: 87-88).

En un contexto social caracterizado por la violencia y la constante resignificación de valores, el juego puede ser visto en ocasiones como algo ridículo o como una pérdida de tiempo. Las objeciones pueden resumirse en la siguiente pregunta: ¿para qué introducir juegos si las demandas sociales actuales requieren el abordaje de contenidos y estrategias didácticas comúnmente consideradas más serias y productivas? Desde otro enfoque, si pensamos en el juego como un contenido universal (y no como un instrumento pedagógico asociado exclusivamente a la infancia), quizás podamos hallar allí propuestas más atrayentes y acordes a las demandas de una sociedad en constante movimiento.

La propuesta en relación al juego consiste, en pocas palabras, en vincular este contenido con el abordaje "pedagógico" o "positivo" de problemáticas vinculadas en algún punto con la violencia; asimismo, proponemos pensar en el juego como un contenido universal y desligado de la carga histórico-política que lo asocia automáticamente a los conceptos de infancia, ocio y tiempo libre. El desafío consiste en reinventar el juego en la adolescencia y adaptarlo para abordar cuestiones significativas; creemos que la exploración de este inagotable recurso abre las puertas a la solidaridad, el respeto, la negociación y el acuerdo, cualidades que desalientan por completo el empleo de la fuerza. Aquí resulta pertinente atender los aportes de Crisorio:

Los juegos ayudan a construir una independencia social y moral, que conduce más lenta pero más seguramente a la reciprocidad y a la cooperación. Esta potestad sobre sí mismo resulta indispensable, además para que los sujetos sean dueños del control que las coerciones sociales ejercen (y ejercerán) sobre ellos (2010: 197).

Consideramos que el juego, entendido como una práctica adaptable a cualquier nivel educativo, merece la misma consideración que cualquier otro saber. En la propuesta que aquí se pretende esbozar, el juego no opera como "cosa de chicos" o "cosa poco seria", sino como una estrategia para el abordaje pedagógico de la violencia a través del uso responsable del cuerpo y el empleo de la palabra. Siguiendo esta línea, a través del juego también es posible estudiar el cuerpo desde un enfoque no convencional, desatendiendo el 
reduccionismo anátomo-fisiológico característico de las ciencias biológicas para, desde otra perspectiva más asociada al estudio de las prácticas corporales, explorar el conocimiento de sus potencialidades, sus limitaciones y las consecuencias que las acciones propias tienen sobre el cuerpo de los demás. Para que estos temas puedan ser trabajados, es menester que exista un trabajo previo dirigido a la pautación de reglas, el reconocimiento de la ley ${ }^{98}$ y la tolerancia al fracaso (tanto por parte de los alumnos como por parte de los docentes). En otros términos, un puñetazo no debería representar una falta únicamente porque a un profesor se le antojó que así sea; se trata de acuerdos sociales de mayor envergadura y expresados en una serie de códigos, los cuales demarcan los límites de las acciones singulares. El desafío para los educadores de hoy, más allá de la especificidad disciplinar, "no es ponerle un límite a la violencia, sino construir sujetos capaces de definir los límites de la propia violencia y capaces de articular su individualidad con el conjunto" (Bleichmar, 2008: 60).

Es preciso destacar que la creación de espacios para el juego monitoreado y pedagógicamente dirigido no conlleva ningún tipo de desautorización sobre el resto de las actividades educativas. Incluso en las escuelas de hoy en día persisten opiniones en contra del juego que lo acusan de inservible y descontrolado, y no faltan quienes lo consideran como un catalizador de "conflictos violentos". En lo hasta aquí desarrollado se pretende demostrar exactamente lo contrario: que el juego no solo no afecta las relaciones de autoridad y la transmisión de contenidos, sino que, por el contrario, promueve la generación un clima lúdico capaz de movilizar a los alumnos desde una propuesta no convencional. Retomando los aportes de Arendt (1996), la oposición juego-autoridad es una construcción que remite al ascenso de las actividades productivas que caracterizan a la época moderna. Siguiendo esta línea, nos animamos a afirmar que ni el juego socava la autoridad, ni la función de ésta debe ser abolir el juego. En otras palabras, más juego no significa menos autoridad, ni tampoco significa mayor violencia.

\footnotetext{
${ }^{98}$ Sobre la relevancia de la ley en el asunto de la violencia en las escuelas, se destacan los aportes de Bleichmar, quien recalca que la ausencia de acuerdos claros a escala social constituye un mal de época en el que parecería que cualquiera puede hacer cualquier cosa. Siguiendo esta línea, la autora destaca que hoy resulta imperioso trabajar sobre la pautación de reglas, no de manera represiva, ya que dicho modelo hoy se muestra poco efectivo y propenso a cometer excesos, sino a través de la negociación y la búsqueda de acuerdos perdurables. En términos de la autora: "el problema en la escuela no está en la puesta de límites, sino en la construcción de legalidades. Porque el límite es exterior, no educa. Aunque a veces haya que ponerlo en la base de la instauración de ciertas leyes" (Bleichmar, 2008: 33).
} 


\subsection{El valor socializador de los deportes}

En la mayoría de los currículos escolares y proyectos educativos pensados para el nivel secundario en los que se incluye el deporte, el argumento siempre suele ser el mismo: su valor socializador. El propio Diseño Curricular para la Educación Secundaria contempla la relevancia del deporte como un medio de socialización, arguyendo que en el mismo

Se despliegan las capacidades sociales y relacionales que permiten la construcción de normas y reglas, el desarrollo de la solidaridad, la cooperación, el respeto, la ejercitación de su responsabilidad y el fortalecimiento de vínculos con los demás (Dirección General de Cultura y Educación de la provincia de Buenos Aires, 2010: 28).

Las causas de esta vinculación pueden hallarse en la génesis misma de los deportes: además de constituirse como una práctica de distinción social, su creación fue pensada para reglamentar ciertos juegos populares y comportamientos inicialmente asociados a la violencia y el descontrol.

Todo deporte [...] es una actividad de grupo organizada y centrada en la competición entre al menos dos partes. Exige algún tipo de ejercicio o esfuerzo físico. El enfrentamiento se realiza siguiendo reglas conocidas, incluidas -en los casos en que se permite el uso de la fuerza física- las que definen los límites de violencia permitidos (Elias,1992: 190).

La codificación e institucionalización de los comportamientos excesivos fue muy útil para el proceso civilizatorio encabezado por los países más industrializados, que tiene su origen a mediados del siglo XIX (y se expande globalmente hasta nuestros días). Si bien podría considerarse que la función original del deporte fue la sublimación y el apaciguamiento de los jóvenes de las clases burguesas que asistían a las public schools, este fue tan solo uno de los múltiples usos que posteriormente se le atribuirían a lo largo del siglo XX. El deporte sirvió -y sirve- para la distinción de clases, para el control de las masas, para la comercialización de productos, para la producción de espectáculos y otras tantas utilidades que hoy lo convierten en mucho más que un pasatiempo ocasional. De todos los atributos que comúnmente se le suelen asignar -y al mismo tiempo se le critican-, aquí se centrará la atención en las funciones socializadoras dentro del ámbito educativo.

Como veremos a lo largo de este apartado, la aceptación del reglamento, el respeto por los demás participantes y la aceptación del arbitraje requieren de un minucioso y progresivo trabajo de enseñanza dirigido a la renuncia progresiva al individualismo y el empleo de la violencia. En pocas palabras, podríamos afirmar que la violencia es siempre enemiga del deporte; en el desarrollo de cualquier especialidad -cuando es debidamente 
reglamentada y fiscalizada-, cualquier exceso en el uso de la fuerza constituye una falta (situación que representa una ventaja para el oponente). ${ }^{99}$

Los estudios de Elias (1992) centrados en el deporte como parámetro de medición de ciertas conductas tendientes al autocontrol constituyen una fuente de información ineludible en la temática. El sociólogo alemán caracteriza las sociedades posrevolucionarias como constitutivas de un proceso civilizador, el cual se evidencia, entre otras prácticas, en los modos en que se regulan y ejecutan los deportes. A partir de un minucioso análisis sobre el devenir de la caza de zorros en Inglaterra durante los siglos XVII y XVIII, Elías halla que, a medida que la sociedad inglesa supera los enfrentamientos armados entre bandos que rivalizan por el mando del país, se inicia un proceso de pacificación evidente en las características figuracionales de los deportes. ${ }^{100}$ Aquí confluyen dos procesos específicamente modernos: la constitución del yo -o, en otras palabras, la configuración del ideal de hombre autorregulado- y una progresiva desaparición de comportamientos que remitirían a cierta barbarie o salvajismo.

Podemos hallar un ejemplo de lo mencionado en la matanza de animales: mientras que en la Edad Media se trataba de una práctica socialmente aceptada, hoy en día las actividades que implican la muerte de animales poseen una connotación negativa, generan descontento social y se hallan prácticamente desaparecidas.

Elias contextualiza la Inglaterra del siglo XVIII -sobre todo los primeros añoscomo una época de conflictos y luchas armadas por el poder en las que no se evidenciaba la posibilidad de una rápida salida pacífica. A partir de allí, introduce el análisis de la caza de

\footnotetext{
${ }^{99}$ Los deportes de combate no son una excepción: si bien para el observador externo un golpe de puño o una patada pueden representar, a simple vista, una acción violenta, al estar reguladas por un reglamento no pueden ser caracterizadas bajo ese rótulo. El eje de este tipo de deportes se centra en la posibilidad de entablar una batalla mimética en la que los contactos están previstos y se regulan a partir de un código predeterminado, con lo que no sería pertinente hablar de violencia en tales circunstancias. Sin embargo, algunas prácticas de combate específicamente contemporáneas (como las artes marciales mixtas) introducen una controversial y delicada relación con la violencia. Al promover cierta "espectacularización del knock out", ya no se estaría contemplando el respeto por el oponente, sino su destrucción. Si bien este tipo de actividades podría caracterizarse como uno de las máximos exponentes del deporte-espectáculo, no podemos dejar de preguntarnos hasta dónde la liberación de restricciones (como las inmovilizaciones, el sangrado o los golpes bajos) promueve cierta exacerbación de la violencia, que, lejos de ser penalizada, parece naturalizarse como una parte del show.

100 Bajo la idea de figuraciones, Elias propone analizar los deportes atendiendo tanto al desarrollo de las reglas como a las relaciones de interdependencia que se tejen entre los individuos (arguyendo que estas categorías no pueden analizarse de manera aislada). A partir de sus estudios enfocados en el pasaje de la sociedad inglesa de la Edad Media al siglo XVIII, Elias fue pergeñando una teoría que articula aspectos comúnmente denominados "macro" con aspectos "micro", dando origen a lo que hoy se conoce popularmente como sociología figuracionista.
} 
zorros como modelo empírico para desarrollar algunas de las características estructurales de los deportes. En un proceso que va del desorden a la conformación del parlamento inglés y la consolidación de una sociedad industrial, la caza de zorros es una especie de termómetro empleado por Elias para medir su desarrollo: dado que esta actividad también sufrió cambios determinantes en su reglamentación (pasando de ser una actividad de supervivencia en la Edad Media a un refinado entretenimiento de las clases altas en la época victoriana), el autor afirma que ambos aspectos se hallan influenciados mutuamente. En el comienzo de Un ensayo sobre el deporte y la violencia, ${ }^{101}$ el sociólogo ratifica la existencia de un paralelismo entre "la difusión desde Inglaterra de modelos industriales de producción, organización y trabajo, y [...] la difusión de actividades de tiempo libre del tipo conocido como «deporte»"(1992: 185).

Centrando la atención en la cuestión de la violencia, el sociólogo advierte que, mientras que en un comienzo la caza de zorros era llevada a cabo directamente por las personas, a lo largo del siglo XVIII se incluye la utilización de perros para esta tarea. Este pasaje de matar con las propias manos a dejar que los mastines lo hagan y experimentar placer durante el proceso, evidenciaría cierto progreso hacia la civilización. En palabras del propio Elias:

La dirección de los cambios experimentados en la manera de cazar, si se contrasta el ritual inglés de la caza de zorros con anteriores formas de caza, muestra muy claramente la dirección general de un empuje civilizador. El aumento de las restricciones sobre el empleo de la fuerza física y en particular sobre el hecho de matar y, como expresión de estas restricciones, el desplazamiento del placer experimentado cometiendo actos violentos al placer experimentado viendo cometer actos de violencia, pueden observarse como síntomas de un empuje civilizador en muchas otras esferas de la actividad humana (1992: 199-200).

El placer de la caza de zorros, por lo tanto, ya no descansaría únicamente en la matanza, sino en la extensión del proceso de cacería (mediante la implementación de una serie de limitaciones cada vez más complejas, hoy conocidas como reglas). La muerte rápida del zorro a punta de cañón significaría una culminación veloz del proceso; en cambio, las restricciones propuestas tenían como objetivo extender el placer devenido de la persecución. De esta manera, se establece un equilibrio de tensiones entre el proceso de

${ }^{101}$ La lectura de este texto suele complementarse con los comentarios posteriores de Eric Dunning explicitados en el escrito Lazos sociales y violencia en el deporte. Ambos textos fueron publicados en 1986 como capítulos del libro Deporte y ocio en el proceso de civilización. Pese al tiempo transcurrido desde su publicación, estos textos aún son considerados fuentes ineludibles para el estudio del deporte, la violencia y la civilización. 
persecución y la muerte del animal, lo que aseguraría la experimentación de una tensiónemoción agradable. "La violencia se practicaba con animales en lugar de seres humanos, [...] las personas disfrutaban con la muerte del animal cazado de una forma indirecta, como observadores" (Elias, 1992: 203).

El desplazamiento de cazar por supervivencia - para obtener alimentos- a cazar por deporte -para obtener placer, esto es, "una emoción agradable derivada de la batalla mimética" (ibíd.: 202) - es un pasaje que se alinearía con la constitución de una sociedad más civilizada. En este proceso Elias introduce dos categorías: un avance en el umbral de sensibilidad y la formación de la conciencia. La primera de ellas hace referencia al crecimiento de las prohibiciones sociales contra el hecho de matar y de ver cómo otros lo hacen. Es por este motivo que el sociólogo encuentra la prohibición de la participación humana en la matanza de zorros como una acción tendiente a la disminución de la violencia. Dunning se va a pronunciar a favor de esta hipótesis arguyendo que estamos en presencia de un "declive en el anhelo de atacar [...]. Esto ha llevado consigo, primero, un descenso en el umbral de rechazo al derramamiento de sangre y otras manifestaciones directas de la violencia física" (1992: 275). La segunda categoría se desprende directamente de la primera y se centra en la inclusión de animales en el proceso de caza. Si bien hoy en día esta práctica resultaría bastante controversial, la inclusión de mastines representaba por entonces "la irradiación del sentimiento más allá del objetivo inicial” (Elias, 1992: 203). El distanciamiento en el acto de dar muerte y el empleo de otros animales para ejecutar la presa significan, para el autor, una especie de "ejercicio de la conciencia" que aleja al humano de un comportamiento "primitivo". Para Dunning, a su vez, "la interiorización de un tabú más estricto sobre la violencia [...]. Consiguientemente tienden a brotar sentimientos de culpa cada vez que este tabú es violado" (1992: 275).

En este contexto de creciente civilización, el deporte representa una especie de invento social que resolvería dos problemas derivados de vivir en una sociedad cada vez más "organizada". Por un lado, determina qué hacer con el tiempo libre, y por otro, canaliza positivamente la tensión derivada de vivir bajo ciertas restricciones.

Volviendo al tema que nos ocupa, algunos estudios realizados en torno al fenómeno de la violencia en las escuelas han introducido herramientas teóricas originalmente 
pensadas por Elias (Castorina, 2008; Kornblit, 2008; Kantarovich, Kaplan y Orce, 2015). ${ }^{102}$ Las investigaciones mencionadas coinciden en un punto: la coexistencia de procesos históricos de civilización y subjetivación con otros, fechados en el presente, tendientes a la des-civilización y la des-subjetivación. En otras palabras, los aportes del autor mencionado pueden colaborar para entender mejor de qué manera una sociedad que se pronuncia -al menos desde el discurso- renuente al uso individual y abusivo de la fuerza, convive a diario con un volumen preocupante de manifestaciones de este estilo.

Castorina, por ejemplo, afirma que la teoría de la civilización no opera de manera lineal, como si se tratase de un proceso "evolutivo" que terminaría para siempre con el recurso de la violencia; por el contrario,

Los comportamientos violentos y las prácticas de pacificación se anclan en procesos civilizatorios de sociedades particulares y con individuos e interrelaciones concretas. Esta caracterización evita, justamente, que se pueda acusar a Elias de haber postulado procesos orientados hacia un progreso abstracto e irreversible [...]. La evolución social se abre no solo a los procesos civilizatorios sino también a otros des-civilizatorios (2008: 93). ${ }^{103}$

Es decir que, a pesar de un manifiesto rechazo general de la violencia, ciertos condicionantes sociales como la desigualdad, la exclusión, la inseguridad y la discriminación pueden promover, al mismo tiempo, el desencadenamiento de hechos comúnmente considerados "violentos". "La civilización convive con las áreas donde predomina la regresión hacia formas de relaciones humanas des-civilizadas" (Kantarovich, Kaplan y Orce, 2015: 61). ${ }^{104}$ Desde esta perspectiva, podría decirse que las manifestaciones frecuentemente asociadas a la violencia en el escenario escolar contemporáneo no son

\footnotetext{
${ }^{102}$ Sobre las contribuciones de Elias a la cuestión de la violencia en las escuelas, Castorina recalca que, en vez enfocarse en precisiones conceptuales y aspectos metateóricos, los aportes de Elias sirven por "el modo de plantear las preguntas de investigación; en la dialéctica del distanciamiento y el compromiso que da cuenta de las vicisitudes de los investigadores sociales; sobre todo, en la construcción de una teoría social que permite vincular a la violencia con las configuraciones, fuera y dentro de la escuela" (2008: 92).

103 Este presunto carácter esencialista o evolutivo posiblemente se corresponda con el enfoque interdisciplinario que envuelve la obra de Elias. Si bien se lo suele considerar el padre de la sociología figuracionista, sus teorías sirven de referencia para estudios provenientes de campos académicos muy diversos.

${ }^{104}$ En Violencia escolar y climas sociales, Kornblit también hace referencia al "proceso de des-civilización”, que define como un "proceso caracterizado por el bajo control de las emociones, agresiones, inestabilidad emocional e importancia de la corporalidad en la expresión de los conflictos" (2008: 15). En este contexto, la "corporalidad" se refiere a la imposibilidad de representar -mediante recursos simbólicos- una posición, un descontento, una diferencia, etcétera. En línea con lo que Dunning (1992) denomina lazos sociales fragmentarios, el uso del cuerpo para la exteriorización de emociones también podría considerarse como una consecuencia de la falta de represiones. De acuerdo al autor recién citado, en las sociedades más avanzadas las manifestaciones físicas son sustituidas por mecanismos de negociación y lo "corporal" es sublimado en actividades legítimas como el deporte.
} 
arrebatos aislados, sino que ocurren como resultado de una descomposición social que trasciende los límites de la escuela; más específicamente, como consecuencia de la desestructuración de las condiciones de vida asociadas al estado de bienestar. Kantarovich, Kaplan y Orce sintetizan muy bien esta lectura "figuracionista" del fenómeno estudiado:

Las investigaciones más relevantes a nivel internacional sobre las manifestaciones actuales de violencia en las escuelas, dan cuenta de que este fenómeno sólo puede ser comprendido en el contexto de sociedades profundamente desiguales, fragmentadas y polarizadas (2015: 55).

\subsection{Deporte, violencia y educación}

De acuerdo con lo desarrollado hasta aquí (y pese a que el análisis de Elias está más enfocado al proceso de la civilización y la deportivización que al estudio específico de la violencia), ${ }^{105}$ esperaríamos una distinción clara entre deporte y violencia, que reconozca en el primero una potencia socializadora que la educación no debería desatender. Sin embargo, Crisorio (2010) advierte que el deporte es -con frecuencia- acusado de "violento", conflictivo o tendiente al descontrol. La asociación entre deporte y la violencia remite a una serie representaciones provenientes de otros campos "que tienden a condenarlos en cuanto actividades competitivas, que llevan en sí mismas la rivalidad y la agresión, e incitan a la violencia en los propios deportistas y en los espectadores" (Crisorio, ibíd.: 190). El problema aquí es que la competitividad y las utilidades económicas que rodean el deporteespectáculo convierten a este tipo de prácticas en algo mucho más complejo e intrincado que una simple lucha de carácter mimética, inicialmente pensada para sublimar tensiones. Por lo tanto se vuelve imprescindible discernir entre deporte-educación y deporteespectáculo, entre una práctica pensada para la socialización de las nuevas generaciones y otra ligada a la espectacularización y la obtención de ganancias. ${ }^{106}$

\footnotetext{
${ }^{105}$ En la conferencia publicada bajo el título Civilización y violencia, Elias menciona algunas precisiones respecto de su interpretación de la violencia, estas pueden ayudarnos a entender mejor su perspectiva: "normalmente, a la hora de investigar el problema de la violencia se sigue un enfoque erróneo. Se pregunta, por ejemplo, cómo es posible que los seres humanos cometan asesinatos [...]. Cuando en realidad la pregunta debería ser enfocada de otra manera, de manera opuesta: ¿cómo es posible que tantas personas convivan de manera -relativamente- tan pacífica?" (1981: 65). Siguiendo esta línea, resumidamente podría decirse que, conforme el proceso de la civilización avance, la violencia debería ocupar un lugar cada vez menos relevante en las sociedades contemporáneas.

${ }^{106}$ Con la intención de diferenciar el deporte-educación del deporte-espectáculo, Crisorio sostiene: "es preciso ser más estricto, más meticuloso, sobre todo si se trata el deporte desde un punto de vista educativo, porque su historia, aunque marcada por los grandes acontecimientos de la historia política y económica, es relativamente autónoma" (2010: 189).
} 
Aquí es pertinente atender a los aportes Dunning, quien sostiene la hipótesis de que la recurrencia de episodios violentos, pese al avance del desarrollo civilizador, se produce debido a una creciente importancia del triunfo sobre la participación, o, en términos del autor, al "ascenso de la meta del éxito" (1992: 279). De esta manera, la búsqueda de la victoria como único resultado aceptable promovería el aumento de la violencia de tipo instrumental. ${ }^{107} \mathrm{El}$ creciente profesionalismo y competitividad que se evidencia en deportes como el rugby, el fútbol o el boxeo se vincula estrechamente con el desarrollo de una sociedad altamente competitiva, en la cual una "elaborada división del trabajo genera asimismo una ideología en torno al éxito (...). Esta intensificación de la competitividad conduce al aumento generalizado de la rivalidad y la agresividad" (Dunning, ibíd.: 287).

A diferencia del deporte practicado en contextos escolares, donde, de acuerdo a Meirieu (2007), la violencia siempre debería ser prohibida al mismo tiempo que reelaborada positivamente, el deporte-espectáculo en ocasiones admite -y exacerba- la violencia como una parte más del show; el fútbol argentino de primera división constituye un claro ejemplo. Transpolar y generalizar estas imágenes de forma indiscriminada sobre todo lo que representa el deporte (incluyendo el escolar) constituye, en cierto modo, la reproducción de un discurso irreflexivo que acaba por desatender la potencia socializadora de este tipo de prácticas. Entre los defensores del deporte como práctica tendiente a la simbolización, la pacificación social y la regulación de la violencia, se destaca la perspectiva de Crisorio, quien sostiene que

Una de las particularidades de los deportes, relacionada en parte con la institucionalización de las reglas, es, precisamente y al contrario de lo que piensa mucha gente, el control y la disminución manifiesta de la violencia física. [...] La transmisión de las reglas del juego social en todos sus aspectos y dimensiones es un objeto principal de la

\footnotetext{
${ }^{107}$ En la tipología de la violencia humana pensada por Dunning, el tipo instrumental se refiere al empleo de esta "como medio para asegurar el logro de un fin determinado" (1992: 274). Esto significa que, conforme los deportes se hacen más complejos en su profesionalización, los oponentes pueden recurrir -de manera racional y calculada - a "jugar con rudeza dentro de las reglas y a recurrir a la violencia indebida con tal de lograr el éxito" (ibíd:: 279). Para Dunning, la violencia instrumental se contrapone a la violencia afectiva. La primera es un modo racional y "evolucionado" de emplear la violencia para la obtención de algún beneficio; en cambio, cuando la violencia es "tomada como un fin en sí misma" (ibíd.: 274), es decir, cuando el uso de la violencia no está ligada a la búsqueda específica de algo (o el fin que se persigue no es considerado legítimo), Dunning habla de una violencia "emocionalmente satisfactoria y agradable" (ibíd.). El problema contemporáneo de la violencia en los deportes se vincularía así con un uso racional de la misma, y no con un retroceso en el proceso de civilización. Mientras la violencia afectiva -propia de las sociedades no desarrolladas- decrece conforme avanza la civilización, comienzan a surgir otros modos de violencia más elaborados, dirigidos a alcanzar un fin determinado y asociados a ciertos lazos sociales funcionales.
} 
educación general [...], a la que la enseñanza de los deportes puede contribuir casi como ningún otro contenido de nuestra cultura (2010: 191).

Como se afirmó anteriormente, donde prevalece la violencia no puede desarrollarse el deporte. El problema se suscita cuando estos límites no están claros o cuando la violencia es un modo de interacción no identificado como falta, o, siguiendo a Elias (1992), cuando los límites de la tolerancia a la violencia se encuentran muy elevados. Ahora bien: si una sociedad -como es el caso de Argentina- convive a diario con un problema de violencia a escala social, su irrupción en el contexto de una práctica deportiva no deberá sorprendernos; no obstante no sería coherente culpar automáticamente al deporte por ello. Siguiendo con el análisis de Crisorio:

Si una mirada retrospectiva de corta distancia nos permitiría afirmar que, por lo menos en algunos deportes, el nivel de restricción con respecto a la violencia ha disminuido, alargando esa distancia veremos que el nivel de restricción de la violencia en los deportes de hoy es aún muy alto (2010: 195). ${ }^{108}$

Los hechos violentos ocurridos en el marco de una práctica deportiva no ocurren por la práctica deportiva en sí, sino por una sumatoria de condicionantes sociales que posibilitan -y en ocasiones promueven- este tipo de reacciones: el desconocimiento o la desconsideración de pautas regulatorias, el desinterés por el otro, la "físicalización" de las rivalidades, el desprestigio de las instituciones, la influencia de lo que numerosos autores denominan "violencia social", entre otros factores, hacen que el problema de la violencia haga su aparición en espacios y en prácticas nunca antes influenciados por problemas de esta naturaleza. Sin embargo, es preciso reconocer que la velocidad con la que el "problema de la violencia" se esparce también produce y reproduce prejuicios y señalamientos, en ocasiones de una forma tan apresurada que, como se dijo más arriba, pueden volver "violentos" a aquellos a quienes se pretende excluir u ocultar. Recordemos que la caracterización del "violento" no es un designio neutral, sino que arrastra una historia y una connotación cargada de preconceptos negativos y estigmatizantes. A fin de no repetir este tipo de discursos, consideramos que la enseñanza de los juegos y los deportes no debe presentarse como "juegos para violentos" o "deportes para violentos", ni tampoco reducirse

\footnotetext{
${ }^{108}$ Sobre la necesidad de disminuir aún más los niveles de violencia que se suelen presenciar hoy en día en el contexto general de la práctica deportiva, consideramos pertinente atender a las siguientes palabras de Bayce y De Boni: "estamos todos de acuerdo en que sería mejor que hubiera menos [violencia] de la que hay; y que deberíamos todos tratar de que disminuyera, tanto dentro de las canchas, entre deportistas, como entre los espectadores, en los entornos de las canchas y en la vida cotidiana en general con motivo del deporte" (2017:21).
} 
a lo "terapéutico" o a la "rehabilitación"; en contraposición, recalcamos su valor educativo ligado a la posibilidad de "acercar el cuerpo a la cultura".

\subsection{Conclusiones parciales}

Tanto en el relato de los informantes (jóvenes y adultos), como en las reflexiones de varios referentes teóricos, hemos hallado un elemento que -con diversos matices- se reitera una y otra vez: la materialización del cuerpo o su reducción a una dimensión física, tangible, maleable, destruible. Sea para evidenciar los "altibajos" del proceso civilizatorio, para poner de relieve aquellas tipificaciones que -basadas en el señalamiento de determinados rasgos físicos- operan como estigmas sociales, o para identificar los peligros del pasaje automático al acto, el cuerpo suele ser el epicentro de los miedos comúnmente asociados a la violencia, más específicamente, de los peligros que podrían vincularse a sus usos ilegítimos, individualistas, antisociales, etc.

A partir de este indicio, proponemos repensar el lugar del cuerpo y su inscripción en la cultura como uno de los principales desafíos educativos a la hora de encarar el problema de la violencia en contextos escolares. Si bien podría considerarse que los espacios previstos para la mediación de conflictos en las escuelas parecieran resultar insuficientes, la socialización de las nuevas generaciones es de una responsabilidad que no debería descuidarse bajo ningún pretexto. Más allá de la especificidad disciplinar, los educadores hoy tenemos la responsabilidad de transmitir saberes destinados a introducir algo del orden simbólico que opere como sustituto de la materialización; no todo tiene que pasar por la piel y la carne, no todo tiene que sentirse, que experimentarse, que hacerse. Siguiendo a Southwell:

Aun en el declive de las instituciones modernas, no es posible renunciar a la tarea de socialización, una socialización en suelos menos conocidos y con mayor incertidumbre, pero que pueden -también- ser menos opresivos y más distributivos (1999: 180).

Para llevar adelante esta tarea, es necesario que la educación enfoque sus objetivos hacia una renovada valorización de lo común. La educación en términos generales, y la educación del cuerpo en particular, tienen mucho para aportar en este desafío. En este sentido, aquí se hizo hincapié -de manera hipotética- en el valor socializador de dos prácticas específicas: el juego y el deporte. En tiempos en los que el individualismo se materializa en la carne y el otro parece haberse convertido en un enemigo, hablar de las 
potencialidades socializadoras y pacificadoras del juego y el deporte quizás suene algo anticuado, pero aún creemos que estas prácticas introducen algo que los deportes extremos o los desafíos de las redes sociales no poseen: una historia ligada al desarrollo de la civilización occidental. En este sentido, creemos que el fútbol y el bungee jumping no pueden agruparse bajo el mismo concepto de deporte, no solo porque tienen reglas y objetivos diferentes, sino porque implican cuerpos diferentes.

La predominancia de actividades asociadas a la experimentación de un cuerpo mudo, lejos de tratarse de una moda pasajera o una práctica asociada a las nuevas generaciones, revela, en términos eliasianos, la incursión -cada vez más recurrente- de prácticas tendientes a la des-civilización. Recordemos que la experimentación -y la exaltación- de un cuerpo mudo dificultan considerablemente la vida en relación con otros. La acción violenta -entendida resumidamente como una exteriorización física desarticulada del lenguaje- constituye uno de los ejemplos más representativos, ya que, al tratarse de una acción individualista con secuelas materiales, sus efectos destructivos afectan tanto al destinatario específico de la agresión como al entorno social.

A modo de síntesis, podríamos decir que, al desalentar las manifestaciones violentas e individualistas, el juego y deporte podrían constituir una herramienta fundamental para "aproximar" el cuerpo a la cultura. El autocontrol, el reconocimiento del otro, el respeto a las reglas, los esfuerzos por mejorar el nivel de juego y la tolerancia a la derrota, son algunos de los elementos que promueven el fortalecimiento de los lazos sociales entre todos los actores escolares. Creemos que la enseñanza de estas prácticas se articula perfectamente con el desafío contemporáneo de educar en tiempos en los que la escuela, al igual que otras instituciones, evidencia severas dificultades para adaptarse a los vertiginosos cambios sociales. Recordemos que Elias caracteriza el proceso de la civilización como un camino en constante movimiento, adaptación y readaptación, y que por lo tanto "nuestro entramado social no es definitivo y mucho menos un punto culminante de una civilización como tampoco lo es nuestra forma de comportamiento, nuestro nivel de coacciones, mandatos y miedos" (1987: 531). Esto quiere decir que cada acción tendiente a la des-civilización, como es el caso de la violencia, no debería significar una catástrofe, sino más bien un llamado de atención para combatir los motivos que la precedieron. La escuela -en tanto lugar de encuentro intergeneracional- constituye un espacio privilegiado para esta tarea, ya 
que la enseñanza de la pacificación es una responsabilidad que descansa, en gran medida, en las manos de los educadores. 


\section{Reflexiones finales}

Contrariamente a las teorías decimonónicas, que pretendían estudiar y caracterizar la violencia con el fin de excluir a los "violentos" para preservar lo "bueno" de la sociedad, hoy nos encontramos frente a un proceso de creciente visibilización y estudio de numerosas problemáticas asociadas, en menor o mayor medida, a la cuestión de la violencia. No obstante, esta creciente preocupación por analizar la violencia en las escuelas, la violencia de género, la violencia familiar o la violencia laboral, pareciera no surtir demasiado efecto sobre la constitución del lazo social y los procesos de simbolización, dos factores centrales a la hora de entender el porqué de la problemática planteada.

Cuando un joven decide emplear la fuerza física para resolver un conflicto, lograr un objetivo o reclamar algo, por lo general no lo hace contemplando el daño que le producirá a quien tiene enfrente, ni piensa en la sanción que le caerá después, ni en la posible reprimenda de sus padres; simplemente, entiende que en este mundo no hay mejor recurso que la violencia para ser escuchado, respetado y atendido. Si nadie se ha preocupado en mostrarle al recién llegado que renunciando a la violencia puede construir un futuro mejor (afirmación acaso exagerada, pero sustancialmente verdadera), es porque pareciera que cada vez menos personas creen que esta afirmación tiene validez. Pero, como afirma Elias (1981), ninguna sociedad puede sobrevivir sobre la base de relaciones violentas. El mismo autor insiste una y otra vez en la relevancia de la pacificación para el sostenimiento de la civilización; desde nuestro rol en la docencia y la investigación educativa insistimos en su enseñanza. De acuerdo con Kaplan: "la vivencia de la pacificación representa un aprendizaje donde la escuela encuentra uno de sus mayores retos" (2009: 23).

Como vimos a lo largo de varios capítulos, la renuncia al uso de la fuerza no es algo

que se adquiere con el nacimiento; se trata, por el contrario, de un arduo proceso dialéctico caracterizado por momentos de represión, de enojo, de ira, de frustración, pero fundamentalmente se trata de un trabajo que debe operar sobre la declinación de conductas narcisistas y el reconocimiento de la ley y la autoridad. Creemos que la educación debe invertir esfuerzos simbólicos y materiales justamente allí, en el pasaje del individualismo a la socialización, en el reconocimiento del otro, en la resolución pacífica de las diferencias, 
en la renuncia a la violencia, en los usos legítimos del cuerpo y en la potencia pacificadora del lenguaje.

No hay una respuesta única, ni un funcionario especializado, ni una manera ejemplar de combatir la violencia; de hecho, al afirmar "esta es la mejor receta" estaríamos recurriendo a modalidades de intervención universales y utópicas, que remiten a esquemas ya caducos en nuestros tiempos. Además de ello, un discurso que pretendiera desterrar la violencia por completo se revelaría rápidamente ilusorio y carente de argumentos. Sin ir más lejos, en tiempos de revoluciones la violencia fue el medio predilecto para erigir las estructuras socio-políticas que hoy conocemos; es por esto que no podemos pretender que una sociedad asentada sobre la base de la violencia se deshaga de esta con un documento, un discurso o una guía; en cierto modo esto representa un argumento contradictorio. Siguiendo esta línea, y centrando la atención en el ámbito local, Bleichmar sostiene:

La condena, en general, de la violencia me parece una tilinguería. Sin ella no se podría haber hecho la Revolución de Mayo, o la liberación de Perú y de Chile [...]. Nuestra tarea no es ponerle un límite a la violencia, sino construir sujetos capaces de definir los límites de la propia violencia y capaces de articular su individualidad con el conjunto (2008: 60).

Sin embargo, también rechazamos por completo que "la violencia es inherente a los seres humanos" (como se afirma casi literalmente en muchos estudios referidos a la violencia en las escuelas), como si la violencia fuera un mecanismo de ataque y defensa impreso desde el nacimiento. No solo habría que poner en cuestionamiento qué hay de inherente en el ser humano, sino que además esta afirmación colisiona con otra -igualmente recurrente- que supone que "el problema de la violencia en las escuelas se deriva de un problema de violencia a escala social". Para ser claros en este punto, creemos que la violencia es una consecuencia de las relaciones desiguales de dominación, de la supresión de derechos, de los abusos, de las injusticias, de la amenazas, etcétera. No puede haber "alumnos violentos" porque no hay "humanos violentos": la violencia no es una cualidad innata, esto es una construcción que -inclusive cuando es respaldada por teorías provenientes de diversos campos- es sumamente arbitraria y, sobre todo, peligrosa.

Con el fin de comunicar los alcances de la investigación, decidimos organizar las conclusiones en tres categorías, las cuales, además de recorrer en menor o mayor medida la totalidad de la tesis, sintetizan la información más relevante en términos de hallazgos: 
Discrepancia: Al momento realizar un diagnóstico inicial sobre el problema de la violencia en las escuelas, pudimos observar que el discurso preponderante en los medios masivos de comunicación revelaba -a través de un tratamiento crudo y sensacionalista- un panorama sumamente hostil, como si las escuelas se hubiesen convertido en escenarios de batallas donde todos sus agentes se entrelazan diariamente en enfrentamientos con secuelas físicas y materiales severas. Tras analizar este tipo de discursos en detalle, advertimos lo que podría considerarse una discrepancia: en numerosas ocasiones, la información -y sobre todo las imágenes- que los medios transmiten a la sociedad, no reflejan lo que efectivamente sucede en la cotidianeidad de los colegios secundarios públicos. Si bien el hecho de que hoy asistimos a una serie de eventos "inéditos" en la historia escolar argentina es innegable (Bleichmar, 2008), no podemos por ello estigmatizar a todas las instituciones educativas, ni a todos los actores que transitan por sus pasillos. Atendiendo a la información provista por los informantes, si bien la mayoría de los entrevistados adultos no dudó en afirmar que las escuelas en las que fueron entrevistados se hallaban atravesadas por un "evidente" o un "grave" problema de violencia, a la hora de solicitarles más detalles sobre la naturaleza de los hechos que ellos consideraban como "violentos", advertimos que -salvo escasas excepciones- estos remitían a situaciones cuyas causas excedían la injerencia o las posibilidades de intervención del establecimiento al que hacían referencia. Esto quiere decir que el fenómeno, si bien "existe" (es decir, efectivamente hay un problema que puede leerse como un asunto asociado en algún punto con la violencia), se desprende de otro de mayor envergadura, que excede los límites físicos y simbólicos de "lo escolar" y se inscribe en el ámbito de lo social. Dicho de otro modo, el problema de la violencia en las escuelas no puede personificarse en el alumno, el docente o el padre protagonista del caso más resonante del diario matutino; se trata de un fenómeno de gran magnitud cuyas causas trascienden la acción individual de un agente catalogado -arbitraria y tendenciosamentecomo "violento".

Autorregulación: los hechos que los informantes adultos y jóvenes suelen identificar como "violentos" - a la hora de determinar qué entienden o qué parámetro emplean para atribuir dicha adjetivación- se hallan en estrecha relación con dos fenómenos: la reconfiguración de la autoridad y el debilitamiento del lenguaje. Consideramos que estos procesos, si bien 
exceden lo estrictamente escolar, dificultan considerablemente la constitución de lazos sociales en su interior. Como resultado de la investigación, sostenemos que la consecuencia de estos movimientos es la autorregulación de los propios jóvenes y la conformación de un orden clánico o tiránico en el que la violencia -en tanto manifestación física desvinculada de un orden simbólico- circula como un medio de relación naturalizado, habitual, no identificable como falta o trasgresión.

Ampliando esta argumentación, podríamos caracterizar la reconfiguración de la autoridad como un proceso exacerbado en las últimas décadas, en el que los adultos parecieran haberse corrido de las responsabilidades que históricamente fueron atribuidas a ese rol. En este sentido, las entrevistas grupales realizadas a los jóvenes revelaron que, para reclamar justicia, manifestar un descontento o expresar un punto de vista diferente, los alumnos hicieron mención a acciones como "agarrarse a piñas"; "agarrarse a patadas" o “cagarse a trompadas", entre otras. Esta situación revela no solo la desconsideración de los mayores como portavoces de una ley aplicable a la resolución de problemas, sino también la coexistencia de interpretaciones disímiles en la medición de los conflictos y en la legitimación de los usos del cuerpo. Recuperando algunas reflexiones de Meirieu (2007), pareciera que el grupo -incluso ordenado bajo una estructura clánica- tiene algo para ofrecer que no pueden ofrecer los adultos. En un contexto socio-histórico donde el otro constituye un obstáculo y la acción va delante de la palabra, la violencia (de acuerdo con el relato de los estudiantes) es empleada para resolver diferencias, hacerse respetar, ascender jerárquicamente en el grupo de pertenencia, defenderse o exigir algo. El resultado de estas sustituciones, de la influencia de los condicionantes sociales y la ausencia de una asimetría protectora, es la creación de un mundo propio: un riesgoso e inestable artificio en el que las leyes tradicionales son sustituidas por el dominio del más fuerte.

Pasaje automático al acto: tanto en el testimonio de los entrevistados (jóvenes y adultos), como en la bibliografía especializada, hemos hallado una constante que -con algunas variaciones- se repite una y otra vez: la reducción del cuerpo a su dimensión física, maleable y destruible. La imposibilidad de manifestarse mediante recursos simbólicos convierte la piel y la carne en los vehículos frecuentemente elegidos por los jóvenes para materializar las dificultades comúnmente asociadas a la etapa que transitan. Para un joven 
que no puede entregarse a la seguridad y la protección que deberían brindarle las generaciones precedentes $-\mathrm{y}$ que se ve imposibilitado de expresarse mediante la simbolización-, el cuerpo pareciera constituir la única exteriorización posible. Aquí la violencia podría considerarse una respuesta física producida por la falta de recursos simbólicos: un pasaje automático al acto, una acción a través de la cual se hace posible exteriorizar la frustración, la ira, la depresión, la tristeza, etcétera.

El problema que ineludiblemente se le añade a este tipo de manifestaciones es que, tal como advirtió Freud (1992b), la violencia -por su carácter narcisista- dificulta considerablemente la construcción y el sostenimiento de una cultura. Es a partir de una interpretación semejante que este tipo de manifestaciones pueden interpretarse, sobre todo por personas ajenas a la institución educativa, como "amenazas" o "atentados" que, tras interrumpir la rutina escolar, merecen -en ocasiones de manera apresurada- la calificación de "violentas". Si bien es innegable que estas manifestaciones físicas representan un problema para la cotidianeidad escolar, la calificación de "violento" o "violenta" conlleva una fuerte connotación negativa; se trata de una tipificación que podría compararse con caracterizaciones igualmente estigmatizantes tales como la del "criminal", el "delincuente" o el "pibe chorro". Es por esto que consideramos que el problema de la violencia en las escuelas es también un problema de enunciación: no solo porque las adjetivaciones tienen efectos dañinos sobre los sujetos señalados, sino también porque existen argumentos suficientes para considerar que el problema no reviste una intencionalidad específica, es decir, no se trata de un plan sistemático ideado por las nuevas generaciones para atentar contra el status quo. Para concluir, diremos que el pasaje automático al acto -denominación con menos carga negativa que la violencia- es una consecuencia directa de la autorregulación; es una forma de sobrevivir en un "mundo juvenil", tal como se denomina al artificio resultante de la reconfiguración de la autoridad, el debilitamiento del lenguaje, las dificultades en el funcionamiento del sistema educativo público y la exaltación del cuerpo en su sentido físico.

A partir de esta breve revisión y categorización, pretendemos poner de manifiesto la centralidad de la violencia, no como fenómeno aislado, asociado a un grupo singular de sujetos o recluido a unas pocas escuelas, sino como una de las problemáticas sociales más relevantes de estos tiempos (Žižek, 2013). El problema de las sociedades actuales en 
relación a la violencia - a diferencia de aquellas que dieron inicio a la modernidad- es que este recurso hoy no suele ser empleado para derrocar a un régimen político opresor, ni para crear un nuevo orden en su lugar; actualmente la violencia es empleada para satisfacer los deseos más egoístas, hecho que, como se dijo anteriormente, representa un obstáculo para la vida en comunidad. La advertencia realizada por Arendt (2014) a mediados del siglo XX tiene una vigencia preocupante: la vertiginosidad y peligrosidad de los cambios sociales transitados fugaz e irreflexivamente en la época moderna nos conducirán a una masiva glorificación de la violencia. Pareciera que, a medida que avanza la modernidad, la violencia va dejando de ser una acción señalada y penalizada, y pasa a inmiscuirse cada vez más en los asuntos cotidianos hasta el punto en el que su identificación y su represión se vuelven difusas. Esto es particularmente riesgoso para las nuevas generaciones, puesto que, siguiendo la tesis arendtiana, al existir cierta aceptación de la violencia como algo mundano o habitual, niños y jóvenes serán educados en contextos cada vez más hostiles donde se asume que la violencia es, sencillamente, la manera más eficiente de relacionarse con el mundo.

Trasladando estas reflexiones al ámbito escolar, debemos tener en claro que la violencia no puede tratarse con más violencia, ya que con ese tipo de medidas solo se asegurará la perpetuidad de un proceso interminable de odio y venganza, que tarde o temprano estallará nuevamente. Cabe entonces preguntarse: ¿qué podemos hacer, quienes trabajamos en educación, para enfrentar la violencia? Estamos en condiciones de responder que la primera acción en este desafío es reconocer su existencia; pretender que la violencia sea erradicada de manera total y apresurada solo puede promover la aplicación de medidas apresuradas e incompatibles con la realidad. En esta línea resulta pertinente atender a Meirieu, quien no solo rechaza la idea de suprimir por completo la violencia, sino que además propone reelaborarla para que esta no sea destructiva, esto es, desviarla hacia modos de representación simbólicos o, en sus términos, "permitirles a los chicos expresar sus violencias de un modo no violento" (2007: 12). El trabajo, la responsabilidad, la capacitación y el planeamiento de los profesionales de la educación constituyen medidas esenciales para poder llevar a cabo este pasaje; es completamente absurdo que en un país atravesado por un evidente problema de violencia se continúe desvalorizando simbólica y materialmente la educación pública, a sus docentes y a sus alumnos. Es como tener una 
bomba a punto de estallar en la mano y arrojar el dispositivo capaz de desactivarla lo más lejos posible.

Creemos que es sumamente necesario llevar adelante una sostenida y progresiva desarticulación de los nodos que habilitan y promueven el uso de la violencia, e introducir, allí donde no hay lenguaje, algo del orden simbólico que otorgue sentido a esa traslación. La "exigencia" (Meirieu, 2007) se centra en volver sobre los propios pasos tratando de identificar aquellos puntos que deberían reforzarse o cambiarse para no transitar el camino hacia la resolución violenta de conflictos. Insistimos en que no tiene ninguna lógica combatir la violencia con una violencia aún mayor: el reto es desanudar las situaciones conflictivas intentando resolverlas en un marco en el que el empleo abusivo de la fuerza no tenga ningún sentido. Dicho de otro modo, los esfuerzos deben concentrarse en insistir -por intervención de profesionales capacitados, bien pagados y socialmente respaldados- en sustituir la violencia por herramientas simbólicas. De acuerdo con Kaplan: "aunque el fenómeno de la violencia en la escuela está determinado por variables sociales ajenas a ella, también existen variables internas de la institución escolar desde las que se puede operar y trabajar para que la escuela siga siendo un lugar de inclusión” (Kaplan, 2015: 20). La propuesta es simple: no tiene sentido apelar a la violencia porque hay otros recursos -más prometedores y pacíficos- que no operan en el plano físico. La renuncia a la violencia -proceso que debería desarrollarse con el respaldo de las instituciones- abre las puertas a la posibilidad de vivir sin necesidad de construir una muralla en relación al otro. En otras palabras, hay algo que se gana cuando se depone el uso de la violencia (quizás no en términos materiales, pero sí indudablemente en términos simbólicos): la posibilidad de reconocer y ser reconocido.

El empleo de la violencia anula la riqueza del intercambio y la pluralidad; dado que en el encuentro con el otro convergen subjetividades disímiles, resulta imperioso reforzar el ingreso de la cultura para que tales diferencias no sean resueltas apelando a la acción de un cuerpo físico, orgánico y volátil. El uso responsable del cuerpo y la palabra permiten el ingreso a un mundo -inmaterial- en el que no es necesario permanecer a la defensiva, en el que no es necesario atacar para hacerse notar, ni es necesario lacerarse para sentirse vivo.

El desafío de los educadores en estos tiempos es tratar de desalentar y sustituir el empleo de la fuerza apelando a un referente, a una causa, a un proyecto: algo que trascienda 
el plano individual y convenza a todos de que el encuentro con el otro y la construcción del consenso permiten multiplicar las fuerzas individuales y abren la posibilidad de alcanzar objetivos más grandes. En este sentido la pregunta de Southwell es fundamental: “¿Cómo los adultos que trabajamos en la escuela, nos podemos constituir en «cruzadores de fronteras» entre épocas, traduciendo, articulando y ayudando a construir referencias nuevas?” (2009: 175). Ampliando esta pregunta, podríamos agregar: ¿sobre qué referencias contemporáneas podemos asentarnos los adultos que trabajamos en las escuelas para construir una convivencia pacífica? Para responder esto es preciso, antes que nada, repasar brevemente una máxima de Meirieu: "cuando un adulto no tiene autoridad, es porque no encarna el porvenir" (2007: 11). Esto quiere decir que como adultos y como miembros de una sociedad, pero fundamentalmente como educadores, tenemos la potencia y la responsabilidad de brindar herramientas a las nuevas generaciones para que estas ingresen progresivamente a un mundo que ellos mismos puedan habitar y mejorar. "Nuestro trabajo no es simplemente una rutina [...], no vamos simplemente a cumplir un horario, sino que creemos en la posibilidad de mejorar lo que hay o de producir algo nuevo" (Bleichmar, 2008: 57). En otras palabras, los profesionales de la educación debemos proveer aquellos medios necesarios para que los nuevos no colisionen con el mundo, sino que lo habiten de una manera cada vez más pacífica.

Ahora podemos ampliar lo dicho más arriba. No tiene sentido hacer uso de la violencia, pero no porque lo diga un docente, un directivo, un miembro de un Equipo de Orientación Escolar o porque esté redactado en un documento, sino porque hay algo más grande, más fuerte y perdurable que se pierde cuando se emplea la fuerza: la pertenencia y protección de una cultura, la posibilidad de aceptar y de ser aceptado, la posibilidad de construir en vez de destruir. Si quienes trabajamos en las escuelas no creemos fervientemente en la potencia de la educación para cambiar y mejorar el presente, no podemos sorprendernos si los problemas asociados a la violencia -entre otros de igual relevancia- se agravan y multiplican con el paso del tiempo. Con cierto carácter reivindicatorio, es menester que reconsideremos el valor de lo público en nuestras sociedades. Frente al avasallador avance de lo individual y lo privado, la escuela -por su naturaleza pública, convocante y protectora- debería sostenerse, no como un lugar donde la 
violencia ha irrumpido para quedarse, sino como el espacio propicio y oportuno para combatirla. 


\section{Bibliografía general}

- Aranguren, J. (1973). "Sobre la evitabilidad o inevitabilidad de la violencia”. En El futuro de la Universidad y otras polémicas. Buenos Aires: Taurus, 127-149.

- Arendt, H. (1996). “QQué es la autoridad?” y “La crisis de la educación”. En Entre el pasado y el futuro. Barcelona: Península, 101-154, 185-208.

- $\quad$------------ (2006). Sobre la violencia. Madrid: Alianza.

- ----------- (2008). De la historia a la acción. Barcelona: Paidós. (2014). La condición humana. Buenos Aires: Paidós.

- Bayce, R. e I. De Boni (2017). "Preguntas y respuestas básicas sobre violencia en el deporte”. En: Bayce, R. y B. Pereyra (coords.), Violencia en el deporte: discursos, debates y políticas en Uruguay. Montevideo: Universidad de la República, 16-55.

- Benjamin, W. (1995). Para una crítica de la violencia. Buenos Aires: Leviatan.

- Blánquez Fraile, A. (1975). Diccionario latino - español. Barcelona: Editorial Ramón Sopena.

- Bleichmar, S. (2008). Violencia social - violencia escolar. Buenos Aires: Noveduc.

- Brener, G. y C. Kaplan (2015). “Violencias, escuela y medios de comunicación”. En Kaplan, C. (dir.), Violencias en plural. Sociología de las violencias en la escuela. Buenos Aires: Miño y Dávila, 77-102.

- Carabajal, E., R. D’Angelo, y A. Marchilli (2012). Una introducción a Lacan. Buenos Aires: Lugar Editorial.

- Castorina, J. y C. Kaplan (2015). "Violencias en la escuela: una reconstrucción crítica del concepto”. En Kaplan, C. (dir.), Violencias en plural. Sociología de las violencias en la escuela. Buenos Aires: Miño y Dávila, 27-53. 
- Castorina, J. (2008). "Las contribuciones de Elias para el estudio de las violencias en la escuela: Un enfoque epistemológico". En Actas XI Simposio Internacional Proceso Civilizador. Buenos Aires: Universidad de Buenos Aires, 84-94.

- Chaves, M. (2010). Jóvenes, territorios y complicidades. Una antropología de la juventud urbana. Buenos Aires: Espacio Editorial.

- Corea, C. e I. Lewkowicz (1999). ¿Se acabó la infancia? Ensayo sobre la destitución de la niñez. Buenos Aires: Lumen.

- Corominas, J. (1991). Diccionario crítico etimológico castellano e hispánico. Madrid: Gredos.

- Cornejo, R. y J. Redondo (2001). "El clima escolar percibido por los alumnos de enseñanza media”. En Última década, $\mathrm{N}^{\circ}$ 15, Viña del Mar, 11-52.

- Crisorio, R. (2009). "El cuerpo y las prácticas corporales". En El monitor. Sumario № 20, Marzo. Buenos Aires: Ministerio de educación, 20-21.

- - -------- (2010). "La práctica deportiva y la educación en valores”. En Toro, B. y A. Tallone (coords.), Educación, valores y ciudadanía. Madrid: Organización de Estados Iberoamericanos para la Educación, la Ciencia y la Cultura, 187-200.

- ---------- (2011). Homero y Platón: dos paradigmas de la Educación Corporal. Tesis doctoral, Doctorado en Ciencias de la Educación, Facultad de Humanidades y Ciencias de la Educación, Universidad Nacional de La Plata.

- --------- (2015). "Educación Corporal”. En Carballo, C. (coord.), Diccionario Crítico de la Educación Física Académica. Buenos Aires: Prometeo, 167-175.

- D’Angelo, L. y D. Fernández (2011). Clima, Conflictos y Violencia en la Escuela. Buenos Aires: UNICEF-FLACSO.

- Diccionario de la Real Academia Española (2016). Versión en línea. Disponible en: [www.rae.es]. 
- Diccionario Enciclopédico Salvat (1957). Octava Edición. Buenos Aires: Salvat Editores.

- Di Leo, P. (2008). "Violencias y escuelas: despliegue del problema". En: Kornblit, A. (coord.), Violencia escolar y climas sociales. Buenos Aires: Biblos, 17-41.

- Di Pego, A. (2016). "Dilemas de la sociedad contemporánea: educación y política". En Educativa, v. 19, nº1. Goiânia: Pontificia Universidade Católica de Goiás, 943966.

- Duschatzky, S. (2007). Maestros errantes. Experimentaciones sociales a la intemperie. Buenos Aires: Paidós

- ---------- (2008). "Maestros errantes. Nuevas formas subjetivas de habitar la escuela contemporánea". En Tiramonti, G. y N. Montes (comps.), La escuela media en debate. Problemas actuales y perspectivas desde la investigación. Buenos Aires: FLACSO y Ediciones Manantial, 169-177.

- Duschatzky, S. y C. Corea (2013). Chicos en banda. Los caminos de la subjetividad en el declive de las instituciones. Buenos Aires: Paidós.

- Dussel, I. (2005). “¿Se renueva el orden disciplinario escolar? Una lectura de los reglamentos de convivencia en la Argentina de la post-crisis". En Revista mexicana de investigación educativa, vol. 10, $\mathrm{n}^{\circ}$ 27, Distrito Federal de México: Universidad Autónoma del Estado de México, 1109-1121.

- Elias, N. (1981). "Civilización y violencia". En Astheik und kommunication, n 43, conferencia dictada en el Congreso Alemán de Sociología (Bremen, 1980), traducido por Christine Loffler y Francisco Javier Noya, 141-151.

- -------- (1987). El proceso de la civilización. Investigaciones sociogenéticas y psicogenéticas. Madrid: Fondo de Cultura Económica.

- Elias, N. y E. Dunning (1992). Deporte y ocio en el proceso de la civilización. Madrid: Fondo de Cultura Económica. 
- Evans, D. (2007). Diccionario introductorio de psicoanálisis lacaniano. Buenos Aires: Paidós.

- Foucault, M. (2002). Vigilar y castigar. Nacimiento de la prisión. Buenos Aires: Siglo XXI editores.

- Freud, S. (1991). “¿Por qué la guerra?”. En Obras Completas, tomo XXII. Buenos Aires: Amorrortu editores, 183-198.

- ------------ (1992a). “La desilusión provocada por la guerra”. En Obras Completas, tomo XIV. Buenos Aires: Amorrortu editores, 277-289.

- -------- (1992b). "El malestar en la cultura". En Obras Completas, tomo XXI. Buenos Aires: Amorrortu editores, 65-140.

- Furlán, M. (2013). Violencia escolar y transformación. Pautas metodológicas y experiencia institucional. Buenos Aires: Lugar Editorial.

- Gallo, H. (2016). "Del bullying o matoneo: entre agresividad, violencia y confrontación”. En Goldenberg. M. (comp.), Bullying, acoso y tiempos violentos. Buenos Aires: Grama Ediciones, 53-75.

- Garriga Zucal, J. (2016). El inadmisible encanto de la violencia. Buenos Aires: Cazador de tormentas libros.

- Glaser, B. y A. Strauss (1967). "El método de comparación constante de análisis cualitativo". En The discovery of grounded theory: strategies for qualitative research. New York: Aldine Publishing Company, 101-115 [traducido por Floreal Forni:

http://www.catedras.fsoc.uba.ar/ginfestad/biblio/1.10.\%20Glaser\%20y\%20Strauss. $\% 20 \mathrm{El} \% 20$ metodo....pdf.

- Greco, M. (2007). La autoridad (pedagógica) en cuestión. Una crítica al concepto de autoridad en tiempos de transformación. Buenos Aires: Homo Sapiens.

- Hegel, G. W. F. (1968). Filosofía del derecho. Buenos Aires: Claridad. 
- Kantarovich, G., C. Kaplan y V. Orce (2015). "Sociedades contemporáneas y violencias en la escuela: socialización y subjetivación”. En Kaplan, C. (dir.), Violencias en plural. Sociología de las violencias en la escuela. Buenos Aires: Miño y Dávila, 55-76.

- Kaplan, C. (dir.) (2009). Violencia escolar bajo sospecha. Buenos Aires: Miño y Dávila.

- ------------- (2013). "La persistencia de la desigualdad. La condición de subalternidad y el sentimiento de exclusión de los y las jóvenes”. En: Kaplan, C. y C. Bracchi, (comp.) Imágenes y discursos sobre los jóvenes. La Plata: Dirección General de Cultura y Educación, 111-126.

Buenos Aires: Miño y Dávila.

- Kessler, G. (2006). "Dilemas y desafíos de la experiencia educativa de jóvenes en conflicto con la Ley". En Miradas interdisciplinarias sobre la violencia en las escuelas. Buenos Aires: Ministerio de Educación, Ciencia y Tecnología de la Nación, 13-20.

- Kornblit, A. (coord.) (2008). Violencia escolar y climas sociales. Buenos Aires: Biblos.

- Lacan, J. (1953). Lo simbólico, lo imaginario y lo real. Conferencia pronunciada en el Anfiteatro del Hospital Psiquiátrico de Sainte-Anne, París.

- --------- (2003). La familia. Barcelona: Argonauta.

- --------- (1999). El seminario, Libro 5: Las formaciones del inconsciente. Buenos Aires: Paidós.

- ---------- (2009). Escritos 2. Buenos Aires: Siglo XXI Editores. (2010). Escritos 1. Buenos Aires: Siglo XXI Editores. 
- Lalande, A. (1953). Vocabulario Técnico y Crítico de la Filosofía. Buenos Aires: Librería "El Ateneo" Editorial.

- Le Breton, D. (2017). El cuerpo herido. Identidades estalladas contemporáneas. Buenos Aires: Topía editorial.

- Litichever, L. (2012) “¿Qué se regula hoy en las escuelas? Una mirada sobre las prescripciones de los reglamentos de convivencia”. En Revista Iberoamericana de Educación, N. ${ }^{\circ}$ 59/1, Organización de Estados Iberoamericanos para la Educación, la Ciencia y la Cultura (OEI-CAEU), Madrid, 1-10.

- Litichever, L. y otros (2008). "Nuevas y viejas regulaciones: un análisis de los reglamentos de convivencia en la escuela media”. En Última Década, No 28, Año 16, CIDPA (Centro de Estudios Sociales), Valparaíso, Chile, 93-121.

- Meirieu, P. (2003). Frankenstein Educador. Barcelona: Laertes. (2007). Una pedagogía para prevenir la violencia en la enseñanza. Ciclo de Videoconferencias, Observatorio Argentino de Violencia en las escuelas. Corrección y adaptación: Martínez Carranza, S.

- Milstein, D, y H. Mendes (1999). "El juego escolar: un llamado al orden". En La escuela en el cuerpo. Madrid: Miño y Dávila Editores, 55-74.

- Munguía, S. (2013). Nuevo diccionario etimológico latín-español y de las voces derivadas. Bilbao: Universidad de Deusto.

- Narodowski, M. y A. Martínez Boom (2016). “¿Por qué se expande la educación privada?: Aportes para el debate global". En Revista Colombiana de Educación, $\mathrm{N}^{\circ}$ 70, Bogotá, 17-26.

- Nella, J. (2009). "El juego. Un contenido «inútil»”. En: Crisorio, R, y M. Giles (coords.), Estudios críticos de Educación Física. La Plata: Ediciones Al Margen.

- Noel, G. (2006). "Una aproximación etnográfica a la cotidianeidad, el conflicto y la violencia en escuelas de barrios populares". En Miradas interdisciplinarias sobre la 
violencia en las escuelas. Buenos Aires: Ministerio de Educación, Ciencia y Tecnología de la Nación, 39-46.

- Nuñez, P. (2015). "La producción escolar de la(s) juventud(es): desigualdad, convivencia y situaciones de discriminación en la escuela secundaria”. En: Revista Cátedra Paralela, № 12, Facultad de Ciencia Política y Relaciones Internacionales, Rosario, 59-84.

- Nuñez, V. (2005). "El vínculo educativo". En: Tizio, H. (coord.), Reinventar el vínculo educativo: aportaciones de la Pedagogía Social y del Psicoanálisis. Barcelona: Gedisa, 19-43.

- Onetto, F. (2004). Climas educativos y pronósticos de violencia: condiciones institucionales de la convivencia escolar. Buenos Aires: Noveduc.

- Osorio, F. (2006). Violencia en las escuelas. Un análisis desde la subjetividad. Buenos Aires: Noveduc.

- Ortale, S., A. Eguía y M. Rausky (dirs.) (2018). Desigualdad y pobreza en el Gran La Plata. Condiciones de vida en el barrio José Luis Cabezas, Ensenada - 2016. La Plata: Universidad Nacional de La Plata.

- Patierno, N. (2014). “Cuerpo y Violencia en la Escuela Secundaria Básica”. En: I Encuentro Internacional de Educación. Espacios de investigación y divulgación. Tandil: Facultad de Ciencias Humanas (Universidad Nacional del Centro de la Provincia de Buenos Aires), 29 al 31 de octubre.

- ----------- (2016). "El juego como estrategia de intervención para la resolución de conflictos en escuelas secundarias”. En Lúdicamente, vol. 5, No. 9. Buenos Aires: Instituto de Investigaciones Gino Germani (UBA), sin numeración.

------------ (2018a). "La violencia en las Ciencias Humanas: una aproximación a la perspectiva de Hannah Arendt". En Cuadernos FHyCS-UNJu (en prensa), Universidad Nacional de Jujuy: San Salvador de Jujuy. 
- (2018b). "Deporte y violencia: una lectura posible en relación a la práctica y su entorno". En: Actas del XXXI Congreso ALAS, Montevideo: Asociación Latinoamericana de Sociología - Universidad de la República, en prensa.

- Pineau, P. (2008). "Como a noite engendra o dia e o dia engendra a noite. Revisando o vínculo da produção mútua entre escola e Modernidade". En Proposiçoes n.19.n.3 (57). Universidad Estadual de Campinas: San Pablo, 83-104.

- Sierra, N. y S. Wankiewicz (2016). "La violencia desde el Psicoanálisis". En Sierra, N., D. Delfino y V. Ruiz (comps.), Psicoanálisis y educación: un diálogo de encuentros y desencuentros. La problemática de la violencia en la escuela. Buenos Aires: Teseo, 37-45.

- Southwell, M. (1999). "Docencia, tradiciones y nuevos desafíos en el escenario contemporáneo". En Yuni, J. (comp.), La formación docente. Complejidad y ausencias. Córdoba: Encuentro Grupo Editor, 169-199.

(2016). ¿Qué es una buena escuela? Reflexiones sobre lo justo y los vínculos intergeneracionales en la escuela secundaria. Buenos Aires: Editorial Universitaria UNIPE.

- - - (2018). "Notas sobre la intermitente democratización de la secundaria”. En Núñez, P. (comp.), Convivencia y escuela secundaria. Organización de Estados Iberoamericanos (OEI), en prensa.

- Southwell, M. y otros (2015). "Vínculos inter e intra generacionales en la escuela media: cambios y continuidades en el formato escolar, la convivencia y la construcción de la ciudadanía". En Pereyra, A. y otros (comp.), Prácticas pedagógicas y políticas educativas: investigaciones en el territorio. Buenos Aires: Editorial Universitaria UNIPE, 311-340.

- Tiramonti, G. (2008). "Una aproximación a la dinámica de la fragmentación del sistema educativo argentino. Especificaciones teóricas y empíricas”. En Tiramonti, G. y N. Montes (comp.) (2008). La escuela media en debate. Problemas actuales y 
perspectivas desde la investigación. Buenos Aires: FLACSO y Ediciones Manantial, 25-38.

- Tiramonti, G. y N. Montes (comps.) (2008). La escuela media en debate. Problemas actuales y perspectivas desde la investigación. Buenos Aires: FLACSO y Ediciones Manantial.

- Valles, M. (1999). Técnicas cualitativas de investigación social. Reflexión metodológica y práctica profesional. Madrid: Editorial Síntesis.

- Vasilachis de Gialdino, I. (2006). Estrategias de investigación cualitativa. Barcelona: Gedisa.

- Žižek, S. (2013). Sobre la violencia. Seis reflexiones marginales. Buenos Aires: Paidós. 


\section{Leyes, documentos curriculares, planes y programas de educación}

- Congreso de la Nación Argentina (1993). Ley 24.195 de Educación Federal.

- Congreso de la Nación Argentina (2006). Ley 26.206/06 de Educación Nacional.

- Congreso de la Nación Argentina (2013). Ley 26.892/13 de Promoción de la convivencia y abordaje de la conflictividad social en las instituciones educativas.

- Ministerio de Educación, Ciencia y Tecnología de la Nación (2006). Miradas interdisciplinarias sobre la violencia en las escuelas.

- Senado y Cámara de Diputados de la Provincia de Buenos Aires (2018). Ley 14.898 Contra la violencia hacia trabajadores de la educación.

- Gobierno de la Provincia de Buenos Aires, Dirección General de Cultura y Educación (2002). Programa de reformulación de normas de convivencia y disciplina.

- Gobierno de la Provincia de Buenos Aires, Dirección General de Cultura y Educación (2009). Aportes a la construcción de los Acuerdos Institucionales de Convivencia en la Educación Secundaria. Documento de trabajo.

- Gobierno de la Provincia de Buenos Aires, Dirección General de Cultura y Educación (2010). Diseño Curricular para la Educación Secundaria Ciclo Superior. ES4: Educación Física.

- Gobierno de la Provincia de Buenos Aires, UNICEF (2014). Guía de orientación para la intervención en situaciones conflictivas y de vulneración de derechos en el escenario escolar.

- Gobierno de la Provincia de Buenos Aires, UNICEF (2014). Violencias y escuelas otra mirada sobre las infancias y las juventudes. 


\section{Anexos}

Esquema general de preguntas para la realización de entrevistas

\section{A- Información general}

Entrevista número:

Fecha:

Lugar:

Duración:

\section{B- Información profesional (para docentes, autoridades y otros profesionales)}

Nombre:

Título habilitante:

Años de experiencia:

Asignatura o cargo:

\section{C- Preguntas generales}

1-¿Qué significa el término violencia para usted?

$2-¿$ Cree que existen situaciones de violencia en las instituciones educativas? En caso de que su respuesta sea afirmativa ¿por qué cree que provocan esas situaciones?

3-¿Puede distinguir diferentes tipos de violencia? ¿Cuáles? Puede dar ejemplos.

4-¿Qué situaciones de violencia ha presenciado en la institución educativa a la que pertenece?

5-¿Qué estrategias se llevan a cabo ante una situación de violencia?

6-¿Quiénes son los protagonistas más frecuentes en las situaciones de violencia que ha presenciado?

\section{D- Preguntas específicas para profesionales de la educación}

7-¿Hay equipos de trabajo en la escuela? ¿Cuáles? ¿Qué problemáticas trabajan? 
8-¿Qué herramientas pedagógicas utiliza para el abordaje de situaciones conflictivas o problemáticas en el aula/escuela? ¿Conversa sobre esto con sus colegas o con los directivos?

9-¿Qué aporte cree que sería interesante para el tratamiento de la violencia en la escuela? 10-¿Qué piensa usted sobre los Acuerdos Institucionales de Convivencia?

11-¿Qué rol cree usted que juegan los medios de comunicación en este fenómeno? 


\section{Entrevistas}

\section{Entrevista a directora perteneciente a la "escuela del barrio ferroviario"}

Nombre ficticio: Andrea

Duración: 45 minutos

E: -¿Qué entendés en general o qué es la primera imagen que se te aparece cuando escuchás la palabra violencia?

A: -La violencia es un enfrentamiento entre dos personas donde se rompe el acuerdo de convivencia ¿no? Nosotros podemos acordar convivir. En las escuelas secundarias nos regimos por el acuerdo institucional de convivencia, cuando se rompen esos acuerdos que tienen que ver con el buen trato, el respeto mutuo, eh... respetar el derecho del otro como persona en toda su integridad, eh... la no discriminación, la no utilización de bullying; bueno, cuando se rompe alguno de esos, esas estrategias de convivencia que están pre determinadas, entonces se genera una situación de violencia. Especialmente en la escuela ¿no? Estamos hablando del espacio escolar. Por eso hablamos del acuerdo institucional de convivencia, que se estipula, se sostiene en todo lo que es la ley nacional de educación, la ley provincial de educación y los derechos de los niños, jóvenes y adolescentes que también tienen carácter de ley en nuestro país. Tanto nacional como provincial. Ese es nuestro soporte legal y después a partir de ahí se trabaja dentro de las escuelas con acuerdos de convivencia. También sosteniéndolos con valores que están estipulados en la ley, nosotros no podemos no tomar en cuenta esos valores que están escritos en la ley de educación provincial y nacional. A partir de allí se establecen cuáles van a ser las estrategias de convivencia dentro del espacio escuela, si se rompen esos acuerdos entonces aparecen los actos de violencia ¿no?

E: -Una consulta más introductoria, que se me pasó. Contame cuánto tiempo hace que estás trabajando como directora en la escuela.

A: -En esta escuela 9 años. 


\section{E: -¿Y qué cargo de profesora tenés originalmente?}

A: -Yo soy profesora de literatura, de la Universidad Nacional de La Plata. Y tuve varios cargos directivos... fui secretaria de una escuela media, durante 5 años, vicedirectora de otra del mismo nivel durante 2 años y medio, y 9 años continuos como directora de la [escuela del barrio ferroviario]. ${ }^{1}$ Hoy tengo doble cargo porque también soy directora de otra escuela secundaria de la zona hace 2 años.

E: - ¿Y actualmente estás dando alguna materia?

A: -No, no. En este momento no.

E: ¿Lo extrañás?

A: -Sí, lo extraño. Lo que pasa que tengo un problema de cuerdas vocales que no me permite dar clases porque me quedo sin voz. Entonces bueno, por varios motivos elegí los cargos directivos y uno de los motivos es la salud. Que no puedo hablar durante dos horas seguidas porque termino sin voz. Y me cuesta muchísimo recuperarme, entonces me es muy difícil dar clase.

E: - ¿Crees que existen situaciones de violencia cotidiana en los espacios educativos?

A: -Sí. La violencia en los espacios educativos es frecuente. Lo que nosotros no, por lo menos yo ¿no?, digo nosotros más, es un plural que para no decir siempre la palabra yo ¿no? Es un plural que intenta salir del egocentrismo. Pero voy a tratar de hablar en singular y después vos lo escribís como te parezca. Lo que nosotros entendemos, lo que yo entiendo como violencia es que no es una violencia que se instala o es propia del ámbito educativo, sino que es una violencia que está inmersa en nuestra sociedad y en la sociedad en las cuales los alumnos, los docentes, los directivos, los auxiliares participamos. La escuela es un espacio más de esta sociedad. Por lo tanto no hay una violencia escolar y una violencia fuera de la escuela, o no tiene grado de diferenciación sino que en general tiene muchos grados de similitud. Los chicos que, o las nenas que muchas veces son violentos adentro de la escuela también lo son en sus ámbitos privados, sociales, digamos fuera de la escuela

\footnotetext{
${ }^{1}$ El nombre de la institución fue omitido para preservar la identidad de los informantes.
} 
¿no? No es tajante, no hay una propiedad intrínseca del ámbito escolar en diferencia con el ámbito extra escolar.

E: -Claro, históricamente se creía que la escuela era como una isla en la que los fenómenos externos de alguna forma no contaminaban el trabajo de la educación. Pero bueno, ya está demostrado que no es así y que los problemas sociales directamente afectan y de manera tajante sobre la educación.

A: -Seguro. Lo que nosotros vemos es que aparece dentro de un espacio áulico. En un principio, dentro de una escuela un poquitito más grande, personas diferentes, con intereses diversos, con posicionamientos sociales, culturales e ideológicos diversos. Nos encontramos en lo cotidiano y ese encuentro de personas tan diversas debe generar de alguna manera enfrentamientos, desencuentros. Los enfrentamientos y los desencuentros se deberían poder resolver por vía del diálogo. Cuando esa vía de diálogo no existe y se pasa a otro tipo de enfrentamiento entonces ahí aparece la violencia ¿no? O sea nosotros entendemos que uno puede convivir con otras personas en un espacio común, la escuela es atípica por eso, porque es el único espacio donde se da esta posibilidad. Ni siquiera en el ámbito laboral uno encuentra esta enorme diversidad. Entonces en esta enorme diversidad si no se produce el conflicto estaríamos errados, sería ilógico. Debe estar el conflicto, la violencia aparece cuando el conflicto no se resuelve por la vía del diálogo; sino por otro tipo de vías.

E: ¿¿Qué situaciones de violencia se suelen presenciar? ¿Cuáles son las más comunes?

A: -Y la violencia aparece en distintos momentos del año. A principio del año aparecen las violencias de integración, cada uno de los chicos o las chicas que vienen a la escuela quieren integrarse en un grupo. Entonces aparecen estas cuestiones de quién se quiere empoderar del espacio áulico, quién quiere ser líder de determinado grupo y quiénes vienen de ámbitos diferentes. Bueno, estos enfrentamientos se dan generalmente a principio del ciclo. Nos olvidamos muchas veces que somos seres humanos también, que además de seres racionales somos animales y en primavera, con el ciclo hormonal de los adolescentes, estos se alteran y aparece otra etapa de enfrentamientos fuertes que está aparejado con el ciclo vital del ser humano relacionado con la naturaleza. Solo que nosotros a veces dejamos de lado ese aspecto, nos olvidamos que tenemos un aspecto animal muy relacionado con la 
naturaleza, y pensamos que eh... que no sé, que bueno hubo un brote ¿no? De diferencia, de desencuentros, de violencia dentro de la escuela. Esos digamos serían desde el aspecto temporal. Desde el aspecto de relaciones lo que se da de forma más frecuente son grupos que se enfrentan por el posicionamiento dentro de la escuela, varones contra mujeres, y el famoso bullying a la persona que se la considera fea, o gorda, o que no tiene habilidades por ejemplo destreza para jugar al futbol entre los varones, o no es atractiva entre las chicas. En esta escuela no se discrimina por la belleza, se discrimina por la fealdad. O por la gordura, o por la poca destreza que tiene para jugar al fútbol. Al que sabe jugar al fútbol se lo empodera en un espacio diferenciador y se lo pone casi como un héroe y del que todos quieren ser amigos.

\section{E: -Eso también demuestra lo que significa el fútbol en la Argentina ¿no?}

A: -Sí y el posicionamiento del hombre, el macho argentino que debe jugar al futbol.

\section{E: -Y el que no tiene habilidades justamente es el raro, el puto, el distinto.}

A: -Sí. Por eso cuando nosotros trabajamos en Educación Física lo trabajamos en forma mixta. Y cuando el grupo no se trabaja en forma mixta, a los chicos que se declaran homosexuales o que nosotros vemos que tienen cierta tendencia hacia la homosexualidad, en forma privada y muy reservada les sugerimos que tengan actividades con las chicas y en general son aceptadas; y bien aceptadas. Se sienten muy cómodos, hemos tenido pareja de chicos homosexuales novios, varones, y siempre han aceptado trabajar en Educación Física con las chicas y no con los varones... con muchísima normalidad. Porque no se sienten a gusto y sí se sienten a gusto con las chicas. No se sienten a gusto en un ámbito de represión, sino que al revés. Salen de la presión varonil, del machismo que también les genera un maltrato. Eso tiene que ver con este machismo argentino que todavía está fuera de tener rasgos igualitarios con el mundo femenino ¿no? Esta igualdad de género todavía está mucho en los papeles y cuesta...

E: -Son cambios históricos que se generan muy de a poco.

A: -Se hacen muy de a poco. Vamos caminando, pero bueno, todavía falta.

E: -Bien. ¿Recordás algún hecho de violencia que te haya llamado la atención? 
A: -El año pasado hubo varias situaciones de violencia especialmente con un grupo de varones que bueno, estaban muy enfrentados, eh... después en otro momento se enfrentaron a los preceptores y al equipo docente. $\mathrm{O}$ sea era un grupo de chicos que nosotros entendemos que tenían un ámbito familiar y social muy violento, y bueno, como lo dijimos al principio, no podían escindir esa violencia que arrastran desde el afuera y lo volcaban también hacia el adentro. Y tuvimos un grupo de chicos con bastantes conflictos. Lo fuimos resolviendo eh... nunca se resuelve nada de una vez y para siempre, sino que tuvimos picos de acuerdos y descensos. Hicimos reuniones con los alumnos, con el equipo docente entre sí, con las familias y también una vez intervino el inspector de la escuela que fue convocado porque bueno, necesitábamos una voz exterior y que participara un poco también en este tema. A uno de los chicos durante muy poquitos días se lo separó del aula y se lo mando a plan mejora, para darle continuidad pedagógica pero hacer un paréntesis en la relación áulica, hasta que se calmó y pudo volver a reintegrase a las aulas normalmente. Todo ese grupo sin embargo terminó su tercer año, que es nuestro año mayor en la ESB, y se trasladaron a otras escuelas para iniciar su ciclo superior. $O$ sea que a pesar de la violencia que fue significativa, esta fue muy trabajada y pudieron terminar su tercer año y pasar a cuarto.

E: - ¿Cómo tiene que actuar la escuela frente a un acontecimiento violento? Cómo serían los pasos o cómo trabajaron en la escuela de acuerdo a las experiencias anteriores.

A: -Nosotros tenemos un acuerdo institucional de convivencia. A partir de ese acuerdo se establecen distintas estrategias. Por supuesto siempre la primera es el diálogo ¿no? Ahora si hay una riña entre dos chicos que están intentando golpearse lo primero que hacemos es separarlos. Una vez separados dialogamos con las dos personas, preguntamos de dónde viene ese enojo y tratamos de que la escuela intervenga en todos los sentidos. Si podemos hacer un acuerdo entre las dos personas después seguimos dialogando con el equipo y con los docentes. Si vemos que no se puede dar un acuerdo involucramos a las familias y en última instancia hacemos que los chicos reflexionen a nivel de situación reparadora con un escrito, con una exposición, con un dibujo, digamos, con alguna actitud de reflexionar sobre sus derechos y los derechos del otro. Entonces bueno, tratamos de reflexionar sobre estas cuestiones para volver a trabajar cuál es el lugar que le corresponde en el aula, en la 
escuela, y que lo que no nos gusta siempre se exprese a través del diálogo. Normalmente nos pasa que no saben cuándo empezó. Es un "me dijo que me dijeron”, "alguien me dijo que vos me miraste mal", entonces yo te pregunto por qué me miraste mal en forma airada, y el otro dice "a vos qué te importa, yo miro como quiero", y terminan en un enfrentamiento. Entonces cuando uno puede desglosar, analizar en profundidad los motivos de por qué se enfrentaron, ellos perciben que no hay un motivo lógico, hay un teléfono descompuesto que justamente los llevo a esa situación.

\section{E: -Y las causas por lo general son cuestiones efimeras e irrelevantes.}

A: -Irrelevantes, totalmente. Es muy raro que nosotros tengamos situaciones reales de, bueno, una persona que molesta a la otra por algo. Inclusive el año pasado teníamos un chico al que en principio lo llamaban "el blanquito" porque era justamente muy rubio y después bueno... esa situación se fue dialogando y pudimos solucionarla y no hubo ningún enfrentamiento más que algunas burlas a principio de año.

E: ¿Las familias suelen colaborar en estos problemas, o se mantienen más bien al margen? ¿O lo empeoran?

A: -Tenemos de las tres cosas (se ríe), hay familias que se angustian muchísimo porque sus hijos o sus hijas han participado en una acción de violencia o una falta de respeto y hay otras que hemos visto que hasta los alientan. Dicen "Bueno si no te entiende pegale una buena piña", y bueno nosotros siempre explicamos que nadie entiende nada a partir de un golpe. Jamás una persona pudo aprender nada a partir de un golpe, un manotazo, un insulto, sino que todos aprendemos a partir de la cordialidad y del buen trato. Y que cuando uno es golpeado, insultado, lo que tiene ganas es de insultar más fuerte o golpear más fuerte; lo mismo se lo explicamos a los papás y a las mamás. Pero bueno hay papás y mamás que sostienen esta posición y hay otros que dicen no me molestes, yo no tengo tiempo de ir a la escuela, que la escuela se ocupe de mi hijo o de mi hija en el tiempo que le corresponde porque yo no voy a ir. Ellos se desentienden, pero eso marca un grado de violencia muy fuerte en las familias de esos chicos y bueno... obviamente eso se mete adentro de la escuela. Los adolescentes traen problemáticas desde las familias.

E: - ¿Se puede hablar de algún grupo que suela protagonizar los hechos de violencia? 
A: -Los problemas atraviesan a todos pero se fortalece, por decirlo de alguna manera, se repite, más que fortalece en segundo año. Los segundos años son los dos cursos más conflictivos. Y esto podemos pensarlo en casi toda la provincia de Buenos Aires o casi todo el país. O todo el mundo, o sea por la edad y la repitencia...

E: -¿Que sería de 13 a 15 años?

A: -Que sería 13 a 15, es una edad donde las chicas tienen mayor grado de violencia y esto se acompaña con repitencias. O sea, si uno analiza la provincia de Buenos Aires, el mayor grado de repitencia es en segundo año. Entonces ahí es donde se producen los mayores niveles de violencia.

E: ¿¿Hay equipos de trabajo de los EOE en la escuela?

A: -Nosotros en este momento no tenemos equipo. El año pasado contamos con el equipo que venía solamente un día a la mañana y un día a la tarde y tuvieron muchísimas inasistencias por muchos motivos... o sea tuvimos una tarea muy débil con el equipo. No teníamos equipo propio, porque no teníamos equipo de distrito asignado a la escuela, que esa es otra posibilidad, y el equipo era un equipo compartido con otro establecimiento, así que el tiempo de trabajo era mínimo.

E: -¿O sea que el EOE se compartía con varias escuelas?

A: -Sí pero esto no sucede siempre. Hay escuelas que tienen equipos propios. Hay otras escuelas que tienen equipos distritales que se les asigna pero se quedan en la escuela de lunes a viernes, digamos, y hay otros como en estos casos que son los menos, que los equipos se comparten entre dos escuelas. Al revés, estos son los menos, bueno a nosotros nos tocó...

E: -¿Y eso es según la cantidad de matrícula, según la cantidad de años?

A: -No, eso lo definen los inspectores de psicología y el jefe distrital.

E: -¿Hay colaboración por parte de los docentes en el asunto de la violencia? ¿Suelen conversar sobre esto? 
A: -Sí, nosotros en general tenemos una buena aceptación de los docentes y el año pasado trabajamos con una de las docentes especialmente en el Consejo Institucional de Convivencia. El CIC está formado por docentes, por el directivo y por alumnos. Y son los que establecen, cuando hay una situación grave, qué tipo de sanción reparadora debería realizar el alumno o la alumna. Una de las docentes trabajó, como la tenemos a la mañana y a la tarde, estuvo en casi todos los encuentros del CIC, que es este consejo institucional de convivencia. Fue una persona con mucha presencia para solucionar los problemas. Y también tomó en sus clases, eh... el trabajar con los acuerdos institucionales, con los tres principales fundamentos del acuerdo institucional de convivencia, que son respetar a las personas, no discriminar y el tercero dialogar. Entonces se trabajó con esta profesora especialmente, pero con todos los profesores también. Entre los docentes hay un grupo minoritario, muy pequeño en esta escuela, que no se aviene a trabajar en la constitución de convivencia. Hay un grupo muy, muy reducido, pero hay.

E: ¿¿Qué aporte crees que sería interesante para abordar los temas vinculados a la violencia?

A: -Yo creo que uno de los aportes es el equipo. Que está dentro de la ley ¿no? La ley de educación dice que cada escuela debe tener un equipo. ¿Por qué? Porque los chicos y las chicas necesitan dialogar, y no puede ser que el diálogo sea un diálogo con la preceptora, con los profesores y la directora. Tenemos que tener personal especializado que justamente es el equipo. Otra de las cuestiones que se deberían trabajar es que las escuelas tienen que tener espacios, como un salón de usos múltiples y aulas donde los chicos puedan realizar otro tipo de actividades además de las del currículum. Un taller de arte, un taller de jardinería, o sea, donde los chicos puedan desarrollar otro tipo de actividades que no sean solamente las propias del aula. Y donde, por ejemplo, el profesor de Construcción de Ciudadanía pueda tener actividades diferentes a modo de taller. Un lugar en el que se trabajen los derechos, pero a modo de taller, con propuestas. Bueno eso falta en las escuelas, tenemos poco espacio edilicio. Y el poco espacio edilicio hace que se concentre la tarea y estar apilados también es una forma de violencia. El aglomeramiento, el pedir permiso porque no hay lugar, el que no tengamos sillas. En este momento no tenemos una silla para Construcción de la Ciudadanía. Así que si nosotros iniciamos las clases de 
Construcción de Ciudadanía con los chicos sentados en el suelo. Eso es una acción violenta. Eso impide que los chicos vengan con agrado a la materia; o que algunos comiencen a tener ausentismo, que también es otro grado de violencia... entonces no contar con elementos tecnológicos como un cañón o un buen televisor, un DVD donde pueden pasar películas. Porque también esos materiales ayudan a comprender, a poder ver un documental, a poder ver una historieta, a poder ver otras experiencias que acá son muy difíciles. Se requiere de mucha buena voluntad de los docentes. Otra cuestión que ya es más a título personal, es que se debería trabajar -tanto en la universidad como en los institutos de formación docentepara que los docentes que egresen de estas instituciones sepan trabajar con el adolescente de hoy y no lleguen a las aulas diciendo "yo no sé qué hacer". O sea, tienen que tener experiencias en las prácticas docentes para saber cómo trabajar con el adolescente de hoy y salir un poco de lo libresco. Por supuesto que todos tenemos que leer y tenemos que saber las teorías de educación. Pero digo, que la teoría se pueda plasmar en la realidad. Entonces, bueno, si los alumnos de los institutos superiores o de la universidad estuvieran más capacitados para trabajar con el adolescente de hoy no habría tanta brecha. Yo he dado varias charlas en la Universidad Nacional de La Plata diciéndole a los alumnos universitarios próximos a recibirse y a ser docentes de la provincia de Buenos Aires, que no pueden llegar a la escuela imaginándose que los alumnos le van a tirar una alfombra roja haciendo loas de su gran conocimiento ¿no? Que es otra la realidad. Que esa realidad no existe. Entonces bueno, uno tiene que bajarse del pedestal, donde a veces nos encumbra el conocimiento universitario. Yo lo soy: estudiar lingüística a nivel universitario en la Facultad de Letras eh... es interesantísimo, pero es un conocimiento sumamente exhaustivo, minucioso y profundo que después se da de bruces con el aula. Entonces digo, bueno, cómo enseñamos acentuación a un chico que no quiere dejar su celular, o que no quiere abrir su carpeta. Entonces, bueno, esa realidad tendría que trabajarse más en los ámbitos académicos. Para que el docente llegue mejor formado, más preparado con la realidad actual. Y no digo que no tenga que estudiar lingüística ¿sí? Y no digo que no tenga que estudiar profundamente a Chomsky, a todos los demás lingüistas y lo hablo desde mi especialidad, sino que deberían estar proyectándose en el mundo actual, en las problemáticas que tiene el adolescente de hoy. Que es nuestro lugar de trabajo. Son muy pocos los docente que hacen una experiencia solamente universitaria o que hacen una 
experiencia únicamente de investigación. Para el 90\% o más, la principal salida laboral es en las escuelas de provincia. Entonces tendríamos que estar preparados para eso. Eso es un rasgo que además eliminaría mucha violencia dentro del aula. Porque el profesor pretende posicionarse en un lugar que hoy ya no existe; tiene que trabajar desde otros lugares ¿sí? Entonces, bueno, eso sería una cuestión a discutir en el ámbito terciario universitario. Yo di clases en el instituto superior de 12 y 67 pero para maestros y adultos. Yo daba lingüística para maestros de adultos. Y trabajábamos fuertemente estos temas. Porque, bueno, la idea era que, ya que estaban haciendo un posgrado, salieran con un poco más de conocimiento de la realidad tangible de lo que les iba a pasar a ellos en un aula con alumnos. Yo trabaje durante cuatro años en este ámbito y en realidad fue muy enriquecedor.

E: -¿Qué pensás sobre el sistema de sanciones? ¿Crees que colabora en la resolución de problemas, crees que es obsoleto, o que habría que mejorarlo?

A: -Yo creo que la sanción por sí misma, sin el diálogo, sin la reflexión, sin la búsqueda de nuevos acuerdos, y sin la posibilidad de una reflexión escrita, una reflexión con la familia, es absolutamente obsoleta, no tiene sentido de ser. Sin embargo, cuando uno le consulta al grupo de adolescentes, estos son muchos más rígidos en las sanciones que nosotros los adultos. Cuando no es para sí mismo, quieren que al otro que los molesta, o que no le permite aprender, o los está agrediendo, reciba una sanción seria. Si uno le preguntara al grupo de adolescentes ¿qué sanción debería tener un chico que golpea a otro? Lo más probable es que quieran romperle la cabeza o expulsarlo de la escuela.

E: -Algo de eso pasó en los diálogos que tuve con los grupos focales, ellos hablaban de sanciones determinantes y excluyentes...

A: -Siempre y cuando sea para el otro. Entonces eso es una tarea nuestra, de los adultos, tenemos que mostrarle que justamente lo que uno quiere para los demás también aplica para uno mismo. Por lo tanto, si nosotros entendemos que tenemos derecho a aprender, los demás también tienen. Los demás también, y eso es inclusivo al cien por cien, no puede ser excluyente. Por eso siempre hablamos de sanciones reparadoras, o de restitución de acuerdos, o de búsqueda de información. En ningún momento hablamos de expulsión. 
E: -La última, después si surge algo más lo ampliamos: ¿qué rol creés que juegan los medios de comunicación en este problema? ¿Creés que muestran el problema de la violencia tal cual es, que lo magnifican, que hacen un aprovechamiento amarillista, que reflejan la realidad?

A: -Los medios de comunicación aportan enormemente a todos los tipos de violencia. Contra la mujer estigmatizándola, poniéndola en el lugar de prostituta. Los programas de mayor audiencia -como los programas de Tinelli- ponen a la mujer en el lugar de la prostituta que debe mostrar su cuerpo en forma indefectible, lo que hace que, justamente, las mujeres también estén vistas desde esa posición. Programas de violencia callejera, programas de violencia entre adolescentes, el empoderamiento del macho frente a la mujer, frente al otro macho, el golpe como una búsqueda de solución al conflicto... son cosas que están presentes en la mayoría de los programas de televisión. Y si nosotros decimos que los chicos están en un ámbito social, y la televisión está en un ámbito social, obviamente incide. Incide fuertemente.

E: ¿Creés que hay algún tema que se me pasó preguntar? ¿Creés que habría que agregarle algo más a lo que hemos estado charlando?

A: -No, me parece que hemos charlado... por ahí no hemos eh... por ahí tampoco es necesario discriminar distintos tipos de violencia, sexual, eh... bueno, violencia de género, violencia social, violencia económica. Ahora por ejemplo se están usando muchas frases como "negro de plan", "negritos del plan", que también viene mucho de los adultos. Yo he escuchado muchos docentes, a ver, cuando digo muchos en realidad esta escuela es la minoría. Pero he escuchado algunos docentes que dicen "yo me la gano la plata y no necesito de un plan". Cuando uno sabe que las personas que necesitan un plan es porque tienen situaciones sociales y económicas diferenciadoras, conflictivas y necesitan de un plan para poder sobrevivir, o para poder llevar a un hijo al hospital, o para poder comprarle lo mínimo indispensable. En ningún plan conocido se llega a tener el salario mínimo. Por lo tanto no se puede darle de comer con ningún plan en la Argentina a los hijos o a las personas que los tienen ¿no? Son paliativos, para no caer en la pobreza absoluta. Ahora existe la asignación universal por hijo y la obligatoriedad de asistencia a los centros de salud... todo eso con el condimento de la asistencia obligatoria a la escuela. Entonces 
cuando uno escucha esos argumentos se nota muchísimo la discriminación de los adultos, de los docentes, y los chicos entre sí también. Hay que entender por qué una persona necesita un plan. Tener un plan no es algo alegre sino que es algo necesario, es casi vital. Porque sin ese plan no tendrían nada.

E: -¿O sea que han ocurrido situaciones en que los chicos reprodujeron lo que escuchan de los adultos en las casas? ¿Se insultan usando el tema del plan?

A: Sí. Y los adultos en la casa y los adultos en otros ámbitos. No se dice tanto adentro de las escuelas pero se escucha, se percibe, se observa, eh... se escucha en la televisión, se escucha en el barrio, se escucha en la calle. Es un elemento fuertemente discriminativo.

E: -¿Cuál es la relación entre el plan, la asistencia de los chicos a la escuela y a las salas de salud?

A: -La vigencia del plan depende de la asistencia. Se les paga a las familias en forma, por cajero automático, lo que impide que cualquiera se apropie de un diezmo, como en otra época se hacía con las manzaneras. Y esto es ideológico. Eh... por un cajero automático, pero se les retiene un porcentaje que creo que está cercano al treinta por ciento que se les deposita a fin de año cuando presentan la libreta o un certificado que avale que la nena o el nene fue a la escuela y que hizo su asistencia a la salita o al hospital correspondiente. O sea, se le retira un porcentaje y se les deposita cuando presentan esa documentación.

E: -La presentación de la documentación sería un requisito para cobrar la totalidad...

A: -Sí, la documentación incluye escuela y salitas. Eso es para la asignación universal por hijo. Para los chicos que cumplen 18 años, que no tenemos acá en esta escuela, como no tienen plan se les hace muy dificultoso terminar la escuela, entonces ahora se los incluye con el plan Progresar. 


\section{Entrevista a vicedirectora perteneciente a la "escuela de la periferia norte"2}

Nombre ficticio: Verónica

Duración: 58 minutos

E: ¿QQué entendés por violencia en términos generales? ¿Qué es lo primero que pensás cuando escuchas el término violencia?

V: -Generalmente cuando se produce una alteración en el ritmo, digamos, de esta escena armoniosa de la situación de convivencia, de... o de vínculos. Hay una alteración en nivel de estímulo. Por supuesto que en sentido negativo o en sentido destructivo ¿no? Se produce por la, creo que es otra pregunta. Me preguntaste por qué se produce...

E: -Esto es una guía nada más, si querés agregar información, agregala.

$\mathrm{V}$ : -Ah bueno. Bien, entonces...lo que quiero decir cuando hablo de una alteración de pronto viene un adulto o un menor, abre la puerta de manera eh... digamos...

E: - ¿Intempestiva?

V: -Intempestiva, sorpresiva o brusca, y eso produce una alteración y produce una situación de violencia. Vamos a poner que la forma en que lo hizo fue porque estaba contento. Pero hasta que eso se aclara el primer impulso que uno recibe es de esa alteración. Eso produce una situación de violencia, puede ser un alumno o puede ser un adulto. Y sí, se vive a diario en todas las instituciones. Digamos que eso se vive a diario, son hechos que suceden en todos los ámbitos. En las instituciones educativas están los más chicos, que son los que están aprendiendo, se están formando, son los que más les cuesta y a los que más hay que explicarles. Que no levanten la voz, que no tiren un banco, una silla, etcétera. O sea, antes de hablar ya se agarraron a trompadas, eso es muy básico y genera una situación de violencia. Hay otras situaciones de violencia que están en lo verbal y que últimamente está muy de moda hablar de acosos psicológicos, de violencias verbales. Si a veces en un clima como este yo te digo "Nico que feo te quedan esos aros", y, a vos te produce una incomodidad. A partir de la cual, bueno, todo esto puede llegar a ser el origen de cuestiones

\footnotetext{
${ }^{2}$ Es preciso aclarar que hasta poco antes de la realización de la entrevista, fui docente de la escuela a la que se hace referencia, de allí que la entrevistada utilice algunas expresiones coloquiales o rememore hechos ocurridos en el período en el que trabajé en la institución.
} 
más tensas, más complicadas, que es la agresividad, el golpe, la agresividad también verbal, el golpe. Entonces cuantos más hábitos de convivencia y buenas costumbres, se van a presentar menos situaciones de violencia. En la medida que se vayan generando acuerdos, en la medida que tanto los adultos como los chicos comprendan que es necesario respetarse, es necesario sociabilizar.

E: -Recordame cuántos años tenés de experiencia en educación.

V: -Voy a cumplir 30 el año que viene. Empecé la universidad en el año 85 como ayudante de cátedra Y continuo como docente de otra materia hace veintipico de años, y cumplo 30 años en agosto de 2015.

E: -Y contame dónde estás trabajando. ¿Estás trabajando en esta escuela y en alguna otra?

V: -En dos secundarias más y en la escuela de teatro, porque mi primera carrera es escenografía social. Estoy formada en el área de escenografía, eso lo hago de manera particular. Con algunos alumnos en casa, en mi taller. Con respecto a lo que es docencia a nivel secundario, terciario y universitario serían dos o tres secundarias, la escuela de teatro y la facultad.

\section{E: -Tenés un interesante recorrido semanal...}

V: -Tengo un mix que me da a esta altura el derecho o la posibilidad de hablar del tema, es decir, me siento con conocimiento realmente de causa. Cuando a mí me dicen qué mal que salen los chicos, o qué piensan los chicos, o que la universidad esto o que la universidad lo otro, o que el ciclo básico esto, el ciclo básico lo otro, afortunadamente y a veces lamentablemente, porque también es estresante reconozco. Afortunadamente porque uno se capitaliza: conozco a los chicos. Y si volvemos al tema de la violencia tenemos que hablar un poco de lo que es el afecto. Es decir, como conozco a los chicos, yo quiero a los chicos, y me parece que está todo encadenado. No nos manejamos permanentemente con situaciones de violencia en la escuela porque nos queremos. Los grandes estamos preocupados porque los salones estén limpios, porque llegue la merienda reforzada del consejo escolar. Esas cosas ya como primer paso... decir cómo se esperan, cómo ingresan los chicos, cómo es el día a día. Cumplir con el horario, el hecho de que estés en la puerta 
esperando, o que estés, ya te digo, viendo que los salones estén limpios, ya ese tipo de cosas hacen a la no-violencia. Ayuda.

Algunas familias tienen problemas. Entonces muchas veces los chicos terminan expresándolo en el ámbito escolar. Y no es porque el compañero le dijo algo o le tiró una tiza. Sino porque ese chico, probablemente, está afectado por alguna cuestión que está pasando en la casa. Que puede ser una separación o puede ser violencia intra-familiar también.

E: -¿Recordás algún caso en particular?

V: -¿Qué haya sucedido en la escuela o que haya venido el chico?

E: -Que haya sucedido en la escuela, en el ámbito escolar.

V: -Este... no, el que se me aparece es en la otra escuela. Después de una licencia que tomo, cuando llegué a la escuela los chicos se hablaban, se decían cosas feas, y de golpe se levantaron, uno con una silla, el otro con, primero a trompadas y después... y ahí me resultó difícil porque no los conocía, no sabía ni los nombres de los chicos. Entonces llamé a la preceptora, vino la preceptora, después llamé a los padres. Pero esas situaciones de violencia son sumamente incómodas. Y ahora me voy enterando que uno de los chicos tiene problemas, consume drogas, etc., etc. Entonces eso se me aparece en la mente porque me impresionó mucho, y a uno le quedan esos recuerdos, esa impresión. No recuerdo haber tenido en 2014 ni un solo hecho ni de pelea de chicos, y creo que ni siquiera de discusiones; eso es hermoso. El año pasado teníamos una chica que sí se alteraba, ahora pasó a otra sede. Ante un comentario de un compañero o de un docente que a ella la hace sentir eh... mal, incómoda, descalificada, ella reacciona de una manera sumamente violenta y agresiva. Cuando vivimos estas situaciones la chica tenía 16, 17 años. Hemos vivido situaciones muy difíciles con esa alumna. Los padres venían a la escuela inmediatamente, padres muy presentes, la alumna era excelente alumna y ahora está en la facultad. En las conversaciones que teníamos con la mamá, ella me decía que reconocía que le resultaba muy difícil ponerle límites a la hija. Desde jardín la chica decidía. Llegaba ponele y decía, hoy quiero entrar, mañana no, mañana sí... bueno, la chica lo decidía, y en este momento esa chica hace lo que quiere. Entonces si no tuvieron límites en otro terreno...y a veces los padres te pueden 
decir "sí pero yo no supe en ese momento cómo manejar la situación”. Bueno, entonces son diferentes canales por los cuales cada especialista, como docente y como madre: me parece que así como está el afecto en un vínculo que debe ser afectuoso, no tiene que trabajar otras cosas, también tiene que haber buenas limitaciones cuando corresponde y como corresponde. No a todos, sino es, bueno volvemos, el chico que abrió la puerta de una manera intempestiva o aunque parezca agresiva, bueno decirle eso no se vuelve a hacer. Es el trabajo cotidiano. Si se puede mechar también con otra cosa personal, cuando mi hijo era chiquito nosotros vivimos una situación dramática. Cuando mi hijo más chico tenía tres años, con la muerte de mi mamá. Y bueno yo digo, aclaro, digo esto porque creo que fue la consecuencia de que el chiquitito estaba agresivo y pegaba. Tenía tres años y nos pegaba. Supongo que se enojaba porque nos veía mal, y nos pegaba a mi marido y a mí, y antes él no pegaba. Y lo ibas a cambiar y nos pegaba, le ibas a dar de comer y te daba un... y entonces bueno nosotros fuimos a hacer la consulta, fuimos al pediatra para saber qué estaba pasando, que seguramente podía tener que ver con lo de la abuela. Y entonces me acuerdo que nos mandó a ver un psicólogo y le hicimos una consulta, por supuesto estuvimos de acuerdo. Él dijo: “ustedes lo agarran ¿Cuánto pesa el nene? Es una cosita [como diciendo, no es más fuerte que ustedes]. Ustedes lo agarran y lo abrazan fuerte, fuerte. Que él no pueda pegarte.” Es magnífico, eso duró una semana y ya había cambiado, dejo de pegarnos. Lo agarramos fuerte, lo tenemos así, entonces ya cuando ve que no puede. Bueno al tiempo vi en un canal de cable un documental donde los monos, la mamá mona, para evitar que los monitos se peleen cuando son chiquitos los abraza. Muchas veces los humanos son iguales que algunos animales cuando son chiquitos, se enojan uno con el otro. Por ahí es algo como una condición natural del ser humano. Eso es que hay que educarlo y hay que trabajarlo. Cuando el monito se enojaba y se peleaba, la mama mona lo agarra al monito y lo abrazaba, así lo va acostumbrando a relacionarse con los otros, a que se le vaya pasando esa ira. Por eso yo insisto en que si no hay contención y afecto vamos a seguir con complicaciones de violencia en la sociedad y en la escuela. Con respecto a la violencia, sí, te podría hasta decir por momentos como sinónimo que también hay agresividad.

E: -¿Qué hace la escuela frente a un hecho de violencia, cómo actúa? ¿Cuáles son las acciones que se desarrollan? 
V: -Nosotros hemos armado un acuerdo de convivencia. Es fundamental, el primer paso debe ser el diálogo. Tenés que hablar con las personas. Si son los chicos los que se pelean, primero con los chicos. Si es un chico y un adulto, hay que hablar con los padres también. Podés hacer entrevistas individuales también. O también entrevistas grupales.

\section{E: -¿Recordás alguna entrevista grupal en particular?}

V: -Sí, bueno, hubo tres o cuatro en una pelea y yo quise conversar con los tres o cuatro. Y ver qué es lo que estaba pasando. Si hay cosas que no se llegan a resolver, a ver, vamos a tratar de hablar en privado a ver qué es lo que está sucediendo. Inmediatamente. Puede ser paralelo, para mí primero es hablar con los chicos o las personas que están en la discusión, pero inmediatamente se llama a los padres. El adulto responsable, que también va a ayudar a descubrir si está pasando algo o si no hay un hecho externo, el acontecimiento que generó la violencia está en ese núcleo, hay que tratar de descubrir qué es lo que pasó, qué es lo que está pasando que a través del diálogo no se puede resolver. Hay que confiar en un cien por ciento que hay que conversar, charlar, esclarecer, y aunque muchas veces no nos vamos a poner de acuerdo, no tenemos que pegarnos ni tenemos que engendrar situaciones de violencia porque no estemos de acuerdo. Eso es fundamental en la comunidad educativa. Que necesitamos comenzar a hablar de las cosas que nos irritan, que nos hacen mal, que nos ponen mal, y las cosas sobre las que no estamos de acuerdo; todo lo que se pueda se conversa. Después bueno, va a ser como en la política, hay gente que no se pone de acuerdo nunca pero nunca y puede llegar a que eso genere violencia. Son opiniones diferentes. Se trabaja con el acuerdo. Los alumnos saben que no se pueden decir malas palabras, que no pueden, no corresponde, ni de parte del adulto ni de parte del menor. Sea el auxiliar, sea el docente o el alumno. Los padres tampoco pueden venir de manera violenta a la escuela. Los padres también tienen que pensar que se debe respetar, que hay que hablar con las autoridades, con los preceptores cuando hay alguna situación que está fuera de las expectativas de los padres. A veces uno no se da cuenta que los padres esperaban otra cosa, que no está pasando. Bueno, "a ver papá". A veces es necesario hablar de manera particular con algunos padres, con algunos chicos, y otras veces se puede hacer reuniones grupales entre padres y alumnos, todos juntos, sobre todo cuando son peleas de grupo. Siempre en el supuesto caso de que estemos hablando de una pelea de grupo. A veces intervienen factores 
externos que son los problemas barriales. Hay problemas familiares que no hablan solo de la familia. Acá vienen muchos chicos que son primos, tíos, hermanos, y a veces el problema es entre ellos o con otros parientes digamos. Y traen acá esas cosas; porque de pronto se encuentran. Por ahí en el barrio no se ven o saben que no se quieren y se encuentran acá y saltan cosas que pasaron en el barrio. Esas son las más difíciles.

E: -Claro, porque provienen de afuera y explotan adentro...

V: -Claro, además ponele que sean porque tu mamá, tu tía, te dijo, me dijo. Y nosotros podemos conversar con los chicos, llamar a los padres, pero después ir a resolver todas las cuestiones del barrio, si es que hay otra familia que interviene pero no viene a la escuela, eso es un poco más difícil de solucionar. De cualquier manera se trata de que nuestros alumnos vayan aprendiendo a sobrellevar ese tipo de cosas.

E: -Sí, uno como docente queda algo impotente ante esas situaciones porque es como un espectador de los conflictos sociales y familiares que después explotan en la escuela...

V: -Claro.

E: -Te hago otra consulta: ¿qué grupo creés que son más predominantes los conflictos? Los varones, las mujeres, los más grandes, los más chicos...

V-: Las últimas peleas han sido de mujeres. Se ha puesto como de moda las chicas, las adolescentes. 13, 12, 13 años, 14. Hay bastante celo, o cuál sería la palabra...

E: ¿ Competencia?

V: -Sí, por ahí debe ser la competencia. Que creo que si volvemos a lo del monito, el monito compite por los padres. El adolescente, el chico sigue compitiendo para estar más cerca de los padres, eso creo que es una cuestión psicológica, sin darse cuenta. Por eso te digo, no me quiero meter en terrenos, porque por ahí uno lee distintos autores o un día conversa con un psicoanalista y mezcla cosas o trae cosas que por ahí no corresponden. A mí me parece que la competencia es también una cuestión que maltrae y que hay que educarla; que se debe ir educando para que eso sea bueno, que sea una competencia positiva, en los deportes por ejemplo. Pero no una competencia porque la otra tiene mejor piel que yo, o es más joven, o tiene los aros más lindos. También compiten mucho por el 
novio las adolescentes. He visto peleas por chicos que capaz no es contemporáneo, capaz salieron hace dos años. "No, pero vos saliste con el chico que a mí me gustaba hace dos años". A veces se dan esas cosas. Y capaz que a la noche, el fin de semana se encontraron en la casa de una y se acordó de que salía con la otra. Viste a veces no tienen... muchas veces las peleas no tienen ni siquiera, lógico que no van a tener un problema antológico. No puede una pelea tener un problema antológico pero decís, ¿por qué se está peleando? ¿Por ese chico que hasta posiblemente este con una tercera? Pero se dio que apareció esa bronca y no se pudo expresar. Apareció esa bronca porque el ser humano puede, apareció una bronca, ¿por qué no me puede aparecer una bronca? Pero en vez de tirar la mesa contra la pared, ¿qué hago yo? Si tengo un amigo o un familiar con quien tengo mucha confianza y puedo decir: "tengo bronca", y sino en la escuela es tratar de encontrar el referente. Puede ser un preceptor u otro. Puede ser un profesor, hay chicos que buscaron a algún determinado profesor para contarle que habían robado. Porque a veces las cosas se dan. Una chica en Educación Física hace, bueno, no contó nada durante la mañana a las preceptoras. "Dale hacé”, le dice la profesora; "no puedo porque me duele el brazo”. “Pero por qué te duele el brazo?" dice la profesora. Un golpe así que había sido un palazo del padre. Entonces vos decís cómo pudo, cómo está pasando esto y esta chica no vino a contarles a los preceptores. O no fue a un médico y dijo hoy no voy a la escuela, voy al médico. No, aparece una profesora de Educación Física y a esa...no sé si se lo hubiese contado, si no la ponía a hacer ejercicio. Bueno qué pasa con ese palazo que le dio el padre y no sale, no se cuenta, que no se trabaja. Que no se habla. Un día lo va a dar ella. Porque ese feedback también me parece que lo puede hacer el adolescente que no lo procesó. Que no procesa las cosas, que no trabaja, que no se busca.

\section{E: -¿En la escuela hay equipo de EOE?}

V: -Hay un equipo de solo dos personas que atienden a toda la comunidad escolar, los tres edificios, todo lo que es la escuela secundaria y sus anexos. Con lo cual, digamos, el aporte está hecho con toda la voluntad del mundo, pero en realidad las posibilidades son mínimas. E: -¿Y cómo actúa el EOE?

V: -Los EOE lo primero que hacen es tratar de tener una conversación con el niño o con los padres, trabajan en comunión con la escuela. Hasta ahora siempre hemos estado de acuerdo 
en que llegar a aplicar una sanción... eso se analiza con un consejo: primero se revisa el acuerdo, luego se reúne el consejo de convivencia y no es una sola persona la que toma la medida sino un consejo que va a determinar qué tipo de medida y cuán reparadora es esa medida. En general son casos graves como el del palazo que te acabo de citar. Se trabaja con el servicio local y el servicio local atiende a la familia del alumno, del joven, tiene entrevistas con la familia y a partir de ahí se hace todo un desarrollo que lleva tiempo; en esos casos se hacen tratamientos, digamos. A veces se tiene que buscar un psicólogo que acompañe, que ayude al joven, al adolescente o al chico. Y a veces a los padres, muchas veces se llega a la conclusión con ayuda del servicio local de que toda la familia es la que debe tomar, tiene que hacer una consulta y recibir ayuda, un apoyo desde el punto de vista psicológico. A veces se hacen talleres, se han conseguido cursos, esa persona, esa alumna que recibió el golpe se le consiguió un curso de manicura.

\section{E: -¿Para que canalice por ahí?}

V: -Un poco para que canalice y otro poco que esos chicos vayan terminando la secundaria y vayan teniendo posibilidades de trabajo; porque eso también va a ayudar a que haya menos violencia. Porque realmente la persona que no tiene trabajo, que no tiene plata, que no tiene esto, no tiene lo otro, también se va a provocando todo esto. ${ }^{3}$ Ahora, si vos lo vas formando o en arte y oficios o... porque los estudios terciarios y secundarios son más largos. Pero si tienen la posibilidad de hacer un curso, que es lo que se consiguió para esta chica para que pueda en el corto plazo salir a trabajar, ya hay otra cosa en la cabeza de ese joven. Imaginate lo que significa para cualquier persona decir hoy me alcanza y mañana me alcanza para otra cosa y además me quedó un poquito y le compro algo a mi hermanito. "Ah mirá, le puedo dar algo a mi mamá". Entonces eso hace que las cosas mejoren, en todo sentido. Y ni hablar del momento en que estaba haciendo la manualidad, la artesanía o el oficio que vos te sentís también, como vos decís, la cabeza está en otro terreno, es decir desde el punto de vista emocional es una maravilla también ¿no? Hay cursos, hay otras instituciones que trabajan, que acompañan en las situaciones malas a veces, hay otras instituciones que acompañan a la escuela y son las que buscan a veces estas salidas cuando son necesarias.

\footnotetext{
${ }^{3}$ Hace referencia a situaciones comúnmente asociadas con la violencia.
} 
E: - ¿El EDIA por ejemplo?

V: -Claro. El EDIA viene como a trabajar, a ayudar a una escuela. Cuando se produce una situación o vulneración de derecho grave, donde la escuela está un poco limitada o con dificultades para resolver, el EDIA ayuda. Y a la vez está el servicio local, ya te digo, todas esas instituciones que trabajan, que por ahí vienen trabajando desde primaria. Por ahí hay un chico que desde la primaria se lo está acompañando con alguna de estas instituciones, entonces se pone en comunicación con el equipo de orientación de la escuela, el equipo articula con el servicio local, el servicio local si es necesario articula con el servicio zonal, todo depende de la magnitud, de la gravedad. Cuando las cosas son las básicas, son simples y se pueden resolver en la escuela y solamente se necesita una charla con los padres, muchas veces todo queda ahí. Pero cuando hay vulneración de derechos de los niños como abusos, golpes, etc., abandono, en esos casos a veces la escuela se queda un poquito carente de recursos humanos y económicos.

E: - ¿Qué aporte crees que sería interesante para el tratamiento de la violencia, o sea, qué es lo que podría trabajar la escuela?

V: -Bueno yo creo que es eso, es querer el trabajo como vos, como yo sé cómo trabajas. El docente que tiene... esto escuché hace un tiempo de una persona en la universidad que después fue secretario de cultura o no sé si es actualmente, que es Daniel Vinches. Y él dijo una cosa, esas cosas básicas que parecen pavadas pero cuando vos las escuchas así de alguien que escribe y todo decís "y sî". Si vos tenés el tema claro, venís con las convicciones para dar tu clase, estás convencido y estás preparado, el alumno lo percibe. Sabe que vos venís con amor, eso es amor también, bueno, es una forma. Esto que te decía antes ¿no? Realmente hay que estar capacitado, querer lo que uno hace, confiar todos los días, empezar, muchas veces todos los días decís tengo que empezar de vuelta porque ayer me desilusioné. Y mañana a la mañana voy a volver a ser la vicedirectora que va temprano, que va a esperar a los chicos, que va a tratar que estén, se va a fijar que la escuela esté limpia aunque haya habido paro de auxiliares. Entonces si todos hacemos lo que nos corresponde, me parece que, bueno, eso va a ir ayudando a una sociedad que se refleja en la escuela. Con respecto a eso por ahí desde lo personal ¿no? Me parece que el hecho de que cada uno venga aseado y bien vestido y con cariño a hacer su trabajo es un aporte 
importantísimo. La capacitación es fundamental, el no abandono, el decir, bueno, esas cosas que uno ve en la familia, que "ah qué mal está ese chico porque hubo abandono familiar" ¿no? Bueno, la escuela hasta donde puede acompaña al chico; ese acompañamiento y esa contención, dentro de las posibilidades que tenemos, es importante ¿no? Porque entre lo pedagógico y lo institucional a veces queda muy poco tiempo para atender, para ver si a ese chico le está pasando algo. Yo recién hoy pude preguntar a una mamá por qué la nena estaba tan delgada. Porque en otra situación, no sé si vos te acordás de esta chica rubiecita... la tuviste el año pasado, a Katherine. Vos la tuviste en segundo, en primero de buenas a primeras va internada de urgencia al hospital, con neumonía, anemia muy importante, muy avanzada. Y llaman del hospital a la escuela ¿qué hizo la escuela, no se daban cuenta que estaba tan delgada? Y nosotros, yo el recuerdo que tenía era verla pasar al recreo corriendo y jugando con las chicas. Después reviso los libros, tenía re buenas notas, reviso la asistencia y había venido. Esto pasó en vacaciones de invierno porque hubo una situación familiar complicada, y ahí la chica es cuando va a parar al hospital ¿qué observamos nosotros? Que era una nena delgada y blanca, un poco blanca. La preceptora sí comentó que le dijo a la madre "está blanca y estaba delgada", pero las autoridades, para que puedan darse cuenta...

Ahora, si hubiese pasado al revés... que la chica se me desmayaba, yo en ese momento sí me tenía que ocupar sí o sí... “uy se me desmayó la chica en la escuela ¿qué pasó?” Ahora, esta posibilidad que yo tuve ahora de hablar con la mamá, haber podido asociar inmediatamente que era la mamá de una alumna y que estaba muy delgada ¡me llevó dos años! Si se me desmayaba en primer año yo sí la iba a conocer y me iba a dar cuenta, pero ves cómo una prioridad, una cosa que es en ese momento una bomba, me hace trabajar en eso. Y estoy una semana, 15 días, un mes hablando con el médico, con la mamá, con el equipo de orientación, con ver si hay problema familiar, a ver si esto, a ver si lo otro. Y ahí sí me ocupe un mes y pico de una alumna. Ahora, como no le pasó al extremo yo tarde dos años. Lamentablemente eso nos pasa y es una escuela chica. Ahora, si vos me decís qué hace el Normal 2, el Normal 1 con mil y pico de pibes ¿puede la directora? Cuando el hospital llama: “¿qué hicieron que no se dieron cuenta que esa chica estaba muy delgada?” Esa directora no sabe, el número puede saber, y ni siquiera. Cuando le dicen Pérez ¿Pérez es delgada? Qué sé yo si Pérez es delgada. Entonces hay muchas cosas para trabajar en una 
escuela, hay varios ejes de la gestión. Eje institucional, eje curricular y pedagógico. Frente a tanta cosa los valores son esenciales, ese debe ser el aporte desde mi punto de vista. El trabajo responsable, el afecto hacia los alumnos, el cuidado de los alumnos. Y a partir de ahí si tienen que pasar accidentes van a ser verdaderos accidentes, son cosas que se te van a escapar.

E: -Me quedan dos preguntas nada más. Si vos después querés agregar algo me decís. ¿Qué opinas sobre el actual sistema de sanciones?

V: -No, estoy convencida de que hay que hablar, estoy convencida de que la sanción no es lo que repara. No, cuando vos decís cambio de turno, si hablamos de cambiar de contexto en algunas circunstancias muy extremas donde esa convivencia no dio para más, que no, no... no he vivido un solo caso donde no se haya podido mejorar la convivencia. Ahí, pero ponele que llegue a haber esa situación en la que es beneficioso un cambio de ámbito, de contexto. Porque puede ser que en un grupo haya algo muy, muy difícil. Que ponele, volvemos a lo mismo, que sea barrial, que sea personal. Otra cosa amonestación, sanción, te echo, te expulso, no.

\section{E: -La figura de expulsión no existe más ¿verdad?}

V: -No, si vos sacas a un chico de la escuela estás vulnerando el derecho a la educación que es primario, es como comer.

E: -¿Y cuál sería la sanción más grave?

V: -Lo más grave decir bueno, a ver, mañana viene con el adulto. Bueno, "a ver señor adulto y alumno, qué es lo que está sucediendo". Tiene que permanecer en la escuela y se trabaja en la escuela para que esa persona esté mejor, esté realmente adaptada entre comillas. El proceso social se supone que en la primaria ya se está trabajando, el chico aprende a compartir, aprende a convivir, va adquiriendo hábitos, entonces si acá hubo un momento de tensión y estrés hay que hablarlo y hay que trabajarlo, pero no sacarlo. En una familia con problemas agravás las cosas. Lo mandás a una escuela a 10 cuadras, 15 cuadras y tienen más problemas. Tiene que adaptarse a nuevos compañeros, tenés que ver si no se juntó con uno que está, que toma por alguna circunstancia. 
Tenemos un alumno que viene, no hace nada, nada. Un día vine el papá, una familia maravillosa, el papá presente. Me dice: “yo el año que viene lo voy a cambiar de turno ¿qué le parece? Yo lo voy a pasar a la noche". Y digo: "mire, a lo mejor a mí me saca un trabajo de encima, de estarle encima, de llamarlo a usted. Pero ¿cuál es el beneficio?, ¿qué gana usted pasándolo a la noche? Que va a estar todo el día con ese tiempo libre, salvo que lo mande a trabajar y que el chico trabaje. Pero tampoco tiene, un chico chico y no tiene necesidad, no lo va a mandar a trabajar”. Digo, entonces ¿cuál es el beneficio de mandarlo a la noche? Va a estar todo el día con el Facebook, saliendo a la calle posiblemente a hacer algo en algún momento viste que no sea bueno. Porque si el pibe está mañana y tarde en la calle es otro problema. Juan se quería juntar. Tratemos de trabajar para que en el día haga lo que tiene que hacer; que es estudiar, leer, seguir la clase mínimamente. Pero... por eso, esto no sé a qué venía este ejemplo.

E: -Estábamos hablando del sistema de sanciones. Si te entiendo... es más importante reforzar la máxima cantidad de acciones posibles para que trabaje el día a día en vez de aplicar una sanción determinante que implique problemas más graves ¿sería algo así?

V: -Claro. Y después viene el lugar de la otra institución, del otro directivo, del otro preceptor que recibe a ese chico de una escuela que lo expulsó. Ponele que en el mejor de los casos inmediatamente lo incluyan en la otra escuela. Donde el chico va a seguir va a pasar lo mismo, entonces vos vas pasando la papa caliente, todo el mundo larga la papa caliente ¡no es así! Yo le digo al otro directivo "mira, este chico te lo voy a mandar porque acá no hace nada”. Y ese otro va a decir ¡gracias! ¡No es así! Hay que tratar de ver qué es lo que está pasando que no nos podemos desenvolver en el ámbito escolar con un grupo de padres, con adultos que nos guían y que a veces nos gustan y otras veces no.

Hay profesores buenos, profesores malos; no digo buenos y malos sino que tienen mejor acercamiento. Hay profes que se llevan mejor con los chicos y hay profes que ponen una distancia. Hay profes cansados. Profes que corren de acá para allá en una especie de vorágine... entonces vienen acá, se sientan y esperan que el chico rinda, haga, proponga, sea creativo. El chico no es creativo; al chico le podes decir libre, tema libre. El chico, el alumno, el joven, el pibe de secundaria necesita parámetros, guías. 
E: -Quisiera saber cuál es tu opinión respecto de los medios de comunicación, particularmente en relación a la violencia en la escuela.

V: -Primero te puedo decir que es política. Acá hay toda una política destructiva con respecto al proyecto, a esta ley nacional y a la de provincia, y en realidad yo me metí en esto porque me interesaba y empecé a leer y me gusta y estoy de acuerdo. Pero hay gente que quiere boicotear el proyecto de educación. Es bueno, se invirtió mucho, se apostaron muchas fichas, eso es cierto. Por ahí con algunas cosas no sé si estoy de acuerdo, no sé si realmente la notebook, si no se podían haber ambientado como se está haciendo en primaria las aulas móviles, esas que llevan 10 computadoras, bueno ponele 30, hoy trabajamos con la computadora, les explicamos, todos tienen internet, quieren estar toda la mañana. Ahora esto de haberles dado y que estén todos en Facebook... pero son, viste, detalles. Con respecto al proyecto me parece bueno. Me parece importante la inclusión, me parece importante que si la familia tiene dificultades, que los ayude la escuela. Si el chico que vos querés echar de todos lados, puede ir a una escuela inclusiva me parece bien, siempre y cuando hablar de inclusión implique también calidad. Toda la discusión está en cómo haces con la calidad, si el chico es desnutrido, no comprende, bueno vienen un montón de cosas que podés estar semanas discutiendo. En líneas generales el proyecto me parece bueno.

Me parece que los medios magnifican, las cosas pasan, pasaron siempre, pasan en todos lados y en todo el mundo. Hemos visto que un chico puede entrar a una escuela de Estados Unidos con un arma, que no sabes cómo un chico puede entrar con un arma de esa calidad, y mata a 10 pibes. Entonces no me vengan con que es acá, con que es en la provincia de Buenos Aires. O que es este proyecto de inclusión. Hablemos del ser humano. Entonces estas son discusiones que a veces se arman con personas que no están de acuerdo, entonces los medios qué hacen: “¡Ah! ¿Cómo? Estos chicos, estas madres que fueron a pelear a la puerta de la escuela". Bueno, desde que yo era chiquitita yo me peleaba en la puerta de la escuela. Es histórico, muchos padres han hecho eso. Y lo van a seguir haciendo. La otra vez una señora vino por la reinscripción. El secretario le dijo "compre los papeles en la esquina”, cuando vino le digo "los papeles van así y así”, y me grita: “¡eh, por qué no me dicen todo!" Tenés que ver esa señora el enojo que tenía por media cuadra, por nada, porque la salita está al lado para que te firme el médico. Porque la secretaria, por hacerle el 
favor en el momento de la reunión institucional, le dijo: "mire no están inscribiendo, pero compre las planillas en la esquina”, entonces vino con las planillas y dijo "¡qué más me van a pedir, yo traje las planillas!" El hecho de que el médico le firme hace que ese médico sea responsable si el chico tiene un soplo, tiene... qué sé yo, si el chico está en condiciones de hacer Educación Física, que no se nos desmaye en la escuela y esas cosas, eso genera violencia. Eso termina en que salió en el diario un día, porque se le ocurrió a alguno ponerlo en el diario y armó toda una situación.

Hay que tener mucho cuidado con esas cosas. Es una sociedad que está con muchos problemas que a veces repercuten en la escuela. Hay muchos medios que tienen la necesidad también de vender. Hay cuestiones políticas por las cuales se trata de boicotear este plan. Me parece que son varias respuestas, son distintos caminos, pero si vos me preguntás si yo creo en este proyecto, yo creo en este proyecto. Y no es que sea ni K, ni Z, ni M.

E: -De la guía no tenemos más nada, en realidad era si querías agregar algo más que puede haber faltado en el cuestionario, podés agregarlo...

V: -Por ahí hablamos varias cosas eh... sí, en líneas generales las instituciones están con problemas, con problemas de infraestructura, con problemas, eso, que lo social repercute pero... todo eso es una realidad eh, no lo niego, no lo discuto. Pero en algún momento tenemos que salir, tenemos que tener una idea de por dónde vamos a transitar, si no vemos la luz al final del túnel hay que seguir excavando. Pero no bajar los brazos, no ser destructivo todo el tiempo, está todo mal, está todo mal. No, viste, viejo es lo que tenemos, son los pibes que tenemos y es la escuela que tenemos, es el trabajo que tenemos. Yo apagaría el grabador, pero hay gente que hace la cola en secretaría para tomar cargos, colas y colas para tomarlo. 


\section{Entrevista a vicedirectora perteneciente a la "escuela del centro"}

Nombre ficticio: Josefa

Duración: 35 minutos

E: -¿Cuál es su cargo y cuántos años hace que trabaja en Educación?

J: -Soy la vice directora de [la escuela del centro], hace diecisiete años y medio que estoy en el cargo. Comencé como coordinadora de lo que era la EGB y luego concursé y gané el cargo titular como vice directora.

E: - ¿Tiene divisiones a cargo en este momento?

J: -Yo soy profesora en geografía con los segundos años, son chiquititos. Ahora se llama secundaria completa. Somos una de las pocas escuelas que integramos el grupo de secundaria común; desde el 2007 comenzaron los cambios, pero aún hay algunas escuelas que siguen siendo EGB.

E: ¿¿Qué interpreta por violencia?

J: -Yo creo que violencia es todo tipo de acto que te hace salir de tus cabales. En este momento nosotros vemos que hay mucha violencia física, verbal y psíquica. No se generan dentro del establecimiento, obviamente, somos un producto de la sociedad, por lo tanto vivenciamos las mismas cosas que pasan en la calle. No sé si en todas las escuelas pasa lo mismo, pero nuestra población sufre de muchas carencias; no quiere decir que la violencia sea de clases bajas, sino que en las clases medias, bajas, altas, en todas las clases se ejerce la violencia. Pero acá parecería que no saben resolver las cosas con las palabras y los hechos son más contundentes, entonces necesitan descargar enseguida con sus manos. Creo que se comienza siempre con la parte verbal, porque siempre hay alguien que dice algo a otro y es lo que se genera dentro del aula, o en el patio. O ahora la famosa frase: "me miraste mal”. Yo entonces los reúno acá y les pregunto: “¿qué es lo que pasó?” Primero preguntarles por separado qué es lo que sucedió en una pelea, y segundo es juntarlas y decir “¿pero qué problema vos tenés con esta persona?” Y contestan: "me miro mal”. Esa frase es un clásico. De ahí una serie de preguntas, porque ni se conocen. ¿Pero vos la conoces a ella? Te dicen: no, pero se hace la linda, corte piola, gato, botón, y frases que uno escucha. 
¿Pero saben ustedes lo que quiere decir esto? Porque a veces usan jerga de cárcel. Entonces les preguntás: “¿cómo vos tenés contacto con estas palabras?” Y te dicen: “es lo que se usa".

E: ¿En la escuela, usted cree que han ocurrido acontecimientos violentos? ¿Puede rastrear alguno para comentar lo que recuerda?

J: -A principio de año nosotros tuvimos una experiencia con un alumno que venía en el turno tarde que tenía la modalidad de resolver sus cosas con peleas, ya venía de una escuela donde lo habían sacado porque había cometido el mismo acto. Un día, con un alumno que era muy bueno, dice que lo miró mal y que le dijo algo - no sabemos qué le dijo-, y en la puerta de la escuela le pego un cabezazo. Eso trajo un trabajo para con el resto del grupo y para con él, por supuesto. Porque uno no puede permitir que sucedan estas cosas. ¿Qué es lo que pasa que no usan la palabra? Porque se sienten menos. Creen que eso les da como un estatus. Yo pego, yo te pego una trompada. Si se trabaja con la familia, si se trabaja con los alumnos, las cosas tienen que volver a su cauce; además todos tienen que ver que uno se preocupa por ellos, que habla con ellos y que si se tiene que aplicar una sanción se aplica. Está en nuestro acuerdo de convivencia, donde dice que nosotros tenemos faltas leves y faltas graves. Esas faltas tienen diferentes tipos de sanción. Esa sanción puede ser una suspensión de dos días y también puede ser que si un alumno tiene reiteradas sanciones se forme un Consejo de convivencia donde participen un directivo, tres profesores y compañeros o alumnos de la escuela. Entonces entre ellos determinan lo que puede llegar a suceder con este alumno, se eleva al inspector, porque después lo tiene que avalar el director. El director nunca puede pertenecer al Consejo de convivencia, sino que él da el aval y luego se eleva al inspector para saber si se resolvió bien y si correspondía.

E: -¿Quiénes cree que son los protagonistas más recurrentes en los hechos de violencia que recuerda?

J: -En este momento las mujeres y en los cursos más chicos es donde se da más. En los cursos más grandes no, ya se formó el grupo, ya se conocen y ya entendieron que la escuela es un tránsito y que es para pasarla bien y que no es para pasarla mal. Pero yo sigo insistiendo que a veces las peleas se dan por el Facebook. Por ejemplo nos pasó el año pasado una cosa muy rara. Dos íntimos amigos, uno le contestó mal al otro por Facebook, 
se conocen de su barrio y se invitaron a pelear. Entonces cuando nosotros citamos a los padres dicen: ¿pero... si era su mejor amigo? Después se pidieron disculpas, se dieron la mano y se fueron contentos.

E: -¿Cree que la violencia se genera de la escuela hacia afuera o de afuera hacia la escuela?

J: -La violencia se genera del afuera hacia el interior de la escuela, absolutamente. Ellos vienen con esa carga negativa a la escuela, por ejemplo, el tema de la droga... es un problema terrible en estos momentos. Yo lo veo a la mañana, cuando, por ejemplo, se juntan en la otra esquina a fumar antes del ingreso y eso genera otros conflictos. Lamentablemente los baños en hora de clase están cerrados con llave, entonces tiene que acompañarlos el preceptor, porque de esa manera registra que no sea siempre el mismo el que va, como pasaba antes, entonces en la escuela están vivenciando cosas que pasan en su barrio o afuera como por ejemplo los robos. Siempre falta un celular o dinero de un bolso y eso no lo generamos nosotros. Absolutamente lo contrario, enseñamos que eso no debe existir. Enseñamos la no discriminación y sin embargo entre ellos se discriminan, enseñamos la tolerancia y entre ellos son intolerantes, entonces yo creo que hay muchas cosas que ellos viven en sus casas; viven golpes, abusos, abandonos y todas esas cosas se manifiestan acá, que es el lugar donde le dan bolilla. Yo hace veintisiete años que soy docente y no estoy preparada para soportar eso de la violencia y de la droga.

E:-¿Hay equipos de orientación en la escuela?

J:-Sí. Nosotros tenemos una asistente educacional y una asistente de orientación para el turno mañana y el turno tarde. Se alternan sus horarios y días para poder ir abordando todas las problemáticas, porque los chicos vienen con muchas problemáticas. Los chicos vienen a contar todo lo que les pasa en sus casas. Hay mucha depresión, hay mucho problema en los chicos de tristeza y angustia que no tienen donde manifestarlo. Hay muchísimos casos de abusos. Los chicos no se animan a decirlo enfrente de todos, pero sí cuando nosotros vamos viendo, los acercamos al gabinete y trabajamos muchísimo. Los casos que tenemos son enormes la cantidad.

E: ¿¿Cómo suele trabajar el equipo de orientación? ¿Se acercan a los padres? 
J: -Nosotros citamos acá. Si el padre no viene al establecimiento vamos a la casa. Nos ha pasado con chicos que tenían inasistencias reiteradas y ante la no respuesta desde las casas ambas chicas del gabinete se presentan en el domicilio para volver a traer a los chicos a la escuela. Nosotros practicamos muchas cosas extracurriculares. Por ejemplo las clases de violín o proyectos informativos. Hay muchos de ellos que acá se sienten protegidos y se quedan hasta las cinco de la tarde tocando el violín. A la mañana están en la escuela y a la tarde se quedan tocando el violín y la disfrutan y aprenden.

E: -En un acto de cierre tuve la oportunidad de ver la presentación de una banda de rock en la que se veía mucho trabajo de ensayo.

J: -Es que esta bárbaro sacar a los chicos de la calle. Y nosotros también tenemos las actividades de teatro. Los chicos de jornada completa, todos los fines de año presentan una obra. Unos trabajan, otros hacen el vestuario, otros la escenografía, otros se dedican a la música. Todos trabajan en una obra que se presenta en el Pasaje Dardo Rocha donde vamos todos a verlos y ellos sienten que la producción se ve. Para mí es muy importante que los chicos vean su producto. Los chicos hoy no tienen maduración. Tiene maduración para la computadora, para todo lo tecnológico, pero para la abstracción no la tienen. Cuando no tenés la base, se te hace difícil aprender una regla de tres, ecuaciones, etcétera. Entonces lo del teatro motiva a los chicos a que vean una producción de ellos que me parece es fundamental y que no sea todo teoría.

E: -¿Qué aporte cree que sería interesante para el tratamiento de la violencia? ¿Cómo se podría trabajar?

J: -Yo creo que los talleres son importantes y que no sean solamente una charla sino que ellos se sientan partícipes de ello. Cuando hablamos de violencia hablamos de muchas cosas como ya comenté hoy. El ser solidario también ayuda a dejar la violencia de lado, el conocerse, el ser solidario con el otro. Por ejemplo, con la bibliotecaria hacemos la "semana de los anteojos" y entonces juntamos anteojos. Los que ya lo dejaron de usar se lo pasamos a los chicos que los necesitan. También hicimos de bufandas, guantes y medias. Es una manera de acercarse al otro y de alguna manera el otro también siente que todo no es un rechazo en la vida, que no se sienta rechazado por todo el mundo. Yo creo que la violencia se genera ahí. Cuando uno siente que nadie le da bolilla, cuando siente el 
abandono, siente la indiferencia de los demás, eso genera violencia. Lo que hay que evitar es eso y trabajar con los chicos, hacer campaña, hacer trabajo solidario; que acá se sientan protegidos y que acá los formamos fuertes para que puedan seguir trabajando lo mismo en sus barrios, en su casa o donde ellos sientan que existe esa violencia.

\section{E: ¿¿Qué opinión tiene acerca del actual sistema de sanciones?}

J: -Hay una falta de compromiso de los padres. Yo le llamo la escuela sin padres porque lamentablemente los largan solos a los chicos y los chicos no están en una edad para largarse solos. Recién empiezan a vivir. El tema de las sanciones es una alternativa. Lo que más necesitan los chicos es un diálogo en casa. Uno en la escuela le puede explicar mil veces las cosas, pero después cuando salen de acá tienen otro tipo de vida y ¿cómo lo arreglo yo? o ¿cómo lo puedo ayudar yo? El tema de las sanciones, sí, deben existir, pero el tipo de sanciones deberían ser más solidarias, que tengan que hacer algún trabajo comunitario. Por ejemplo, este año escribieron las aulas que habíamos pintado con tanto esfuerzo y los chicos mismos que habían pintado vieron poco después esas mismas paredes escritas. Enseguida y se supo quién había sido, cité a la madre y al nene y le dije: "señora, traé Cif y una esponjita y su hijo se pone a limpiar lo que escribió, porque los demás no merecen eso. Pero la voy a hacer responsable a usted", le dije a la mama, "porque si en su casa escribe las paredes a mí no me interesa, pero acá no las va a escribir” y la madre con el hijo limpiaron las paredes.

E: ¿¿Ha tenido casos en la escuela de violencia de docentes hacia los alumnos?

J: -No. Por lo menos yo no me he enterado.

E: ¿¿Qué rol cree que juegan los medios de comunicación con el tema de la violencia?

J: -Si vos miras "Policías en acción", es terrible. Los noticieros deben mostrarte la realidad y no un hacer show de la realidad. Lo terrible es ver cuando un compañero se está peleando y otro en lugar de ayudar está filmando esa pelea. Los medios de comunicación nos muestran todo lo que está pasando, los robos, las peleas, las peleas en las escuelas. El contenido de los noticieros en un noventa por ciento de violencia, que no deja de ser la realidad. Lo que hay que revertir es eso y la mirada ante eso y que no sea una cosa cotidiana y normal la violencia y que la gente se ande pegando por la calle, sino todos son 
días de furia y todo el mundo sale con el bate a pegarle al árbitro. La violencia la estamos viviendo en la calle cotidianamente; y entre la cordura y la locura hay una línea tan finita que no sabemos cuándo la cruzamos. Nadie está exento de cruzarla, pero está en nosotros poder contemplarla, mirarla un poquito más de afuera y decir: "yo no quiero entrar en esto". Nosotros lo vemos acá, hay madres que vienen furiosas, hay alumnos que te rompen las ventanas porque les agarró un ataque de locura: ¿dónde está la falla y donde está la solución? Nosotros como docentes debemos hablar mucho con los chicos, trabajar para que las cosas les pertenezcan.

E: -Siempre aparece la constante de que el lenguaje y la palabra operan como un factor mitigador de la violencia. Es una constante que aparece en todas las charlas ¿usted qué piensa al respecto?

$\mathrm{J}$ : -A veces uno ve que una alumna viene y dice "se van a pelear porque una le dijo otra cosa a otra", entonces nos anticipa... A ver chicos ¿qué está pasando? ¿Tienen algún problema? Expónganlo, díganlo ¿qué te molesta del otro? Porque tenemos que saber lo que nos molesta. Todo tiene un límite. Vos podés jugar hasta que me molestás porque si es una molestia no jugamos más... y ellos deben aprender que cuando ya están molestando no tienen que seguirla, no tienen que seguir molestando al otro porque hay juegos que tienen límite; tal vez el otro chico no lo toma como juego, sino como agresión, porque no todos aceptamos de la misma manera las cosas.

Como para terminar quiero insistir en que me preocupa mucho la familia. Chicos que la mamá no sabe si los hijos vienen a la escuela o no vienen. Esa cosa de los adultos... que porque estamos trabajando no nos enteramos de lo que hacen nuestros hijos y son chicos. No se les puede permitir a los hijos faltar a la escuela porque se generan hábitos. Si no generás el hábito de la responsabilidad, de los horarios -porque suelen llegar tarde, y el día que vayas a trabajar, si al tercer día llegás tarde te echan de una patada y desaparecés del trabajo-, hay que enseñarles a ellos que esta es la formación para ellos. No solamente les damos información de las materias, nosotros los ayudamos a que formen una personalidad, a que sepan diferenciar lo bueno de lo malo, para eso somos docentes y para eso tenemos esa vocación. Opino que no todo el mundo que está dando clase tiene la misma vocación, no todo el que estudia docencia tiene la facilidad de transmitir. Hay gente que se tendría 
que dedicar a la investigación, porque serán muy buenos escribiendo, pero tal vez no transmiten nada y no llegan a los chicos y si no llegás a los chicos no sirve. Si un docente no se divierte con los chicos tendría que dejar de lado la docencia -son adolescentes y te hacen reír-, es parte del juego. Si yo no me divierto cuando doy clase y no los entiendo cuando hacen un chiste, una broma... el acartonamiento de un adulto no puede existir, porque nosotros debemos ser respetados por lo que somos. ¿Tiene que existir una distancia entre alumno y profesor? Sí, pero una distancia lógica que es el respeto (al igual que el docente le debe tener al alumno). 


\section{Entrevista a preceptor perteneciente a la "escuela del barrio ferroviario"}

Nombre ficticio: Saúl

Duración: 01:54:00

E: -¿Cuántos años hace que trabajás en educación?

S: -Y mirá, yo me recibí en el... 98. En el 98. Y... ahí habré estado trabajando en primaria y en adultos en total unos tres años más o menos, cuatro. Tres años y medio ponele. Después me fui. Porque me dediqué a pintar, que era lo mío, lo que me gustaba. No era la parte artística nada más, también educabas, organizabas talleres pero era una educación no formal. No como esta. Y estuve 9 años más o menos así y habré retomado hace tres años de nuevo. En el secundario. Al mismo tiempo yo daba clases, dos materias en la facultad, en Bellas Artes, como ayudante. Cada vez que estaba acá en La Plata, bueno, estaba dando clases. Lo que me permitía la facultad era también un poco tener una flexibilidad ¿entendés? Viajar, eh... hacer mi otro trabajo de la pintura. Pero en definitiva ponele que hará seis años que estoy dentro de la educación formal. También di talleres para el Ministerio de Educación, en la parte de adultos, también en el Ministerio de Trabajo, convenios que ellos hacían y fuera de mi país en otros lugares para algunas asociaciones civiles donde daba talleres, todo apuntado hacia los valores. Algunos apuntados hacia tener una salida laboral, enseñé serigrafía mucho también. Lo manejaba yo a mi manera, el programa lo armaba yo, no era un programa ya estipulado.

E:-¿ Vos con qué título saliste de Bellas Artes?

S: -Me falta la tesis, para ser licenciado en artes plásticas. Porque tengo todas las materias, me falta la tesis. Además soy maestro de grado, maestro de adultos y bueno, falta la tesis acá.

E: - ¿Maestro de grado? O sea que hiciste el magisterio...

S: -Sí, nunca me interesaron los chiquitos, a mí lo que me interesaba era adultos.

E: -¿Pero igual tuviste que hacer el magisterio? 
S: -Para hacer adultos sí, necesitás magisterio también. A mí me gusta mucho también la parte de relacionarte de par a par, por eso me gustan las preceptorías. Porque vos podés encarar al pibe desde otro lado ¿no? Del contenido.

\section{E: -Contame cómo empezaste a laburar en secundarias.}

S: -Y volví acá al país, este... y quise retomar el trabajo en las escuelas. La parte de adultos estaba complicada para tomar, y lo que es preceptoría, lo que es administrativo a mí siempre me gustó. El hecho de tener un local $^{4}$ viste... siempre me gustó la parte administrativa, y aparte el tema de poder tener una preceptoría es como que tenés una visión amplia de todo, no solamente, quizás no tanto lo que pasa dentro del aula porque en el aula está el profesor, pero sí tenés una visión de lo que pasa en la escuela en general que el profesor no la tiene. El profesor va una vez a la semana, dos veces a la semana y se va. Vos estás todos los días. Estás todos los días con los pibes, conocés mejor a los pibes, no solamente las divisiones que tenés que cuidar, sino que conocés otras divisiones, conocés el funcionamiento de la escuela, la parte administrativa. Porque la escuela además no es un núcleo cerrado sino que tiene relación con otras instituciones y vos tenés que manejar un poco esas cosas. Y conocés a todos los profesores, ¿entendés? Entonces podés también, más que nada cumplir una función administrativa pero además de consejero un poquito. En algunos, consejero en el sentido de que hay un profesor que tiene algún problema con un chico, como va muy poco él no conoce del todo. Entonces vos podés darle lo que ves y lo que observás en el chico en el día a día. Decir "bueno mira, con vos pasa esto, con otro profesor también pasa que tiene el mismo problema con este chico". Entonces viste como que ampliás un poquito el panorama. Y el manejo de la escuela.

E: -¿Qué entendés por violencia? ¿Con qué lo podés relacionar?

S: -Una definición de diccionario no te voy a dar. Para mí todo aquello que choque un poco o rompa con eh... con tu sentido de libertad, libertad en el buen sentido ¿me entendés? Uno tiene una libertad hasta que eh... llega, siempre y cuando no rompás la libertad del otro. Entonces, para mí un hecho violento es eso, algo que puede estar privándote tu libertad, tus derechos, para mí ya genera violencia, o violencia física o... el hecho privarte de un derecho también es una violencia. El hecho de privarte de tu educación o que, en la escuela

\footnotetext{
${ }^{4}$ Hace referencia a un local de venta de indumentaria propio.
} 
por ejemplo... uno ve violencia en cuanto a los chicos y en cuanto a docentes que son violentos con los chicos; también chicos que son violentos entre ellos y docentes que son violentos entre ellos... y también chicos que son violentos con docentes. Y padres que son violentos con quien pueden

E: - ¿Entonces ves violencia en todas las relaciones institucionales?

S: -Hay todo tipo de violencia, digo verbal o... o física, la violencia institucional, también, porque nadie habla de la violencia institucional, también hay violencia del sistema. Para mí este es un sistema que te atrapa y que además está muy corrupto. Y cuando digo corrupto no te digo en el sentido de eh... sí, también puede ser en el manejo de fondos pero yo no lo he visto a eso.

E: ¿ ¿Te referís al funcionamiento del sistema?

S: -En el funcionamiento del sistema a veces uno se siente como que es un peoncito. Entonces cuando uno tiene que sacrificar una ficha en la partida de ajedrez ¿qué sacrifica primero? El peoncito. Entonces uno a veces siente eso, que es un poco descartable. Hoy lo hablábamos con una compañera de allá de la escuela, del secundario. Y me dice que ella también siente lo mismo... como que nosotros somos peones. Si pasa algo el de arriba no se hace responsable. Siempre hay que buscar un culpable, ¿quién es el culpable? El de más abajo. Entonces eso también es un hecho de violencia. Un hecho de violencia también es eh... salta mi postura política pero bueno.

\section{E: -No importa, no tiene incidencia.}

S: -Viene mucha gente con el tema de Conectar Igualdad. Para mí está perfecto que todos los chicos tengan una netbook. Pero si todos los chicos tienen una netbook y en el comedor que yo cuido, les cuentan los fideítos que les dan... eso es violencia. Que vaya un profesor a comer y que la gente de la cocina lo esté mirando a ver cuánto come, para mí es un hecho de violencia también, ¿entendés? Porque el tipo tiene muy bien ganado ese plato de comida, de hecho para mí que el tipo coma, el profesor o el preceptor o el que sea... que todos coman con los chicos me parece que es una acción pedagógica también. También enseña eso. Son momentos de compartir con el chico, el chico aprende. Desde lo básico, cómo sentarse, cómo comer con respeto. Hasta una conversación... entonces esas cosas para mí 
también son violencia. Es feo que empiece a haber roces. Me ha pasado a mí que me han llamado y me dicen "fíjate que los profesores no coman tanto".

E: - ¿Porque se servían varias veces?

S: -Claro, porque capaz que querían repetir. Está bien, uno se tiene que dar cuenta también algunas cosas. Pero también es feo eso... que uno se tenga que estar fijando en cuánto comés. El sistema genera que haya esas cosas, eso es violencia... es violencia también que vos estés cerrando las notas y te den una planilla de cierre de calificaciones, el CIC que le dicen eh... el PIP, que son cierre del primer trimestre, segundo trimestre, bueno. Y es feo que te hagan inventar números para que te cierre el número final. Eso también es violencia, porque uno tiene que hacerlo porque te lo piden de arriba, pero vos en la realidad sabés que estás mintiendo.

E: -¿Te piden determinada cantidad de alumnos aprobados, desaprobados, esas cosas?

S: -Claro. Vos sabés que tenés un instructivo de cómo llenar esa planilla. Pero ese instructivo te lleva a mentir. Es decir, vos llenás la planilla como te dice el instructivo pero vos sabés que ese instructivo hace que todos los números te cierren para que la educación esté bien. ¿Entendés?

E: -¿Cómo se llama ese documento?

S: -Eh... cierre eh... si las veo las planillas me acuerdo. El CIC, el PIC y el... TRIC. El primer informe, mira Primer Informe de Calificaciones, Segundo Informe de Calificaciones y Tercer Informe de Calificaciones, TIC. ¿Sí? TIC.

E: -Después los voy a buscar. Bueno, yo te voy a preguntar por la "escuela del barrio ferroviario", pero si vos querés agregar alguna anécdota que hayas vivido en otra escuela también podés contarme. Con respecto a la "escuela del barrio ferroviario”: ¿creés que ocurrieron hechos de violencia? En caso afirmativo ¿creés que podrías mencionar alguno concreto?

S: -Hechos de violencia los veo en todos los lugares.

E: - ¿En todos los lugares que has trabajado? 
S: -Donde no he visto es en la facultad. Cuando yo daba talleres para el ministerio también veía hechos de violencia entre los docentes. O los docentes hacia nosotros, porque decían que nosotros no nos ubicábamos en la realidad de ellos. Porque nosotros éramos gente que iba a darles talleres a ellos, a explicarles a ellos cómo enseñar y nosotros no estábamos en la escuela, y tenían razón. Entonces se te enojaban y vos los veías a todos disconformes, mal, te contestaban mal, se generaban unos roces. Hechos de violencia que no llegaban a más, pero los tenías. Y en cuanto a la escuela sí, en todos los lugares donde trabajé, escuelas primarias, de adultos, secundarias, todos, no hubo una sola... un solo lugar en mis años de trabajo donde no haya visto violencia.

\section{E: Contame sobre la "escuela del barrio ferroviario"...}

S: -No pasaron dos semanas que yo no haya visto violencia. Capaz que tenía una semana tranquila y ya me sentía extraño... pero la violencia siempre está, ya es parte de la institución. Últimamente vienen muchos docentes a hacer catarsis. Están todos viendo de sacarse tareas pasivas, funciones en el ministerio o en algún gremio porque no quieren volver al aula. Porque están todos mal viste...

\section{E: ¿¿Están como traumados?}

S: -Están todos traumados, preocupados por la situación, buscan la comodidad y yo los entiendo. Y eso hace que no se jueguen... que muchos docentes aprueben y aprueben alumnos para sacárselos de encima. Y a mí me lo han dicho. No los quieren desaprobar porque no los quieren tener de nuevo, no los quieren hacer repetir porque no los quieren tener de nuevo. Se los quieren sacar de encima porque se quieren sacar de encima a los padres. Y aparte porque no se quieren comer una denuncia de algo, porque un día desaprobaste a un pibe y ya al otro día sos un violador, ¿entendés? Veo muchos casos de esos, de hecho este año pasó que amenazaron a dos compañeras, a una la amenazaron con hacerle una denuncia de algo por el estilo. Cosa que es total mentira porque el hecho al que refiere este padre yo estaba ahí, yo vi muy bien cómo sucedió todo y no fue así. Entonces, fue un hecho feo, eh... una situación fea que se dio, donde miente el alumno y donde miente el padre. Acusaron a mi compañera de querer tocar a un chico y yo estaba a tres metros del hecho, ¿entendés? Y había pasado otra cosa totalmente distinta, a lo que después dicen que pasó. 
E: -¿Qué es lo que había pasado?

S: -Yo no puedo creer que un pibe, bueno sí lo puedo creer, que un pibe tan descaradamente mienta incluso adelante mío, sabiendo que yo estaba ahí y todo. Que una madre mienta y que una directora, ¿entendés? Esos son hechos de violencia, esos son hechos que corrompen. Entonces esos son hechos que después cuando uno se juega y salta por un compañero, después cuando uno sale del trabajo y está en su casa tranquilo le empieza a dar miedo. Porque decís: ¿y si ahora por venganza me toca a mí? La abusadora no es solamente ella sino soy yo también.

E: -Claro, cuando uno está solo empieza a...

S: - ¡A maquinarse, a maquinarse! Y esa es la chotada de todo esto. Así es como pasan estas cosas, ojo que también pasan cosas hermosas ¿entendés? Ahora estamos hablando de violencia. Podemos hablar de cosas lindas, también pasan 20 mil cosas lindas. Que vos salís, viste, re contento.

E: -Sí que seguramente son más las lindas que las malas. Porque sino uno no estaría ahí...

S: -Son más los chicos buenos.

E: -Seguro que los días buenos existen, están y obviamente uno va a la escuela por eso también...

S: -Coexisten todos, lo que pasa es que uno se tiene que preocupar a veces de los líos, y deja a los pibes, a los otros pibes de lado. Pero sí, coexisten.

E: -Bueno contame sobre la madre de un alumno que entró saltando una reja ¿puede ser?

S: -Fue la señora que saltó la reja, que quiso ingresar, que ingresó en realidad "de prepo" a la escuela. Yo la frené ahí porque también estaban los de primaria, y no quería que lastime a alguno. Uno no sabe cómo va a reaccionar la gente.

E: - ¿Cómo la frenaste?

S: -Ni la toque. Me puse enfrente y le pedí por favor que se tranquilice, que hable. Y que cuando se tranquilizara yo recién la iba a dejar pasar. Entonces la lleve hacia la puerta.

E: - ¿La acompañaste? 
S: -La acompañé y parece que se arrepintió porque empezó en la vereda viste, que no quería estar en la vereda, quería estar adentro y me empujó el portón de una patada y a propósito me dio con el portón en las manos, me lastimó las manos. Y me dio en el pecho me dicen- que con algo de metal. Yo cuando me vi venir las trompadas me incliné viste. Este... me dio con algo de metal, dicen que tenía, no sé qué. De hecho me quedó en el pecho una marca de una L. Era una marca de una L.... y yo me preocupé porque justo ese momento esa señora iba a ir a buscar a otra profesora. La señora no me creía que ninguna de las dos estaban; quería meterse a la fuerza para buscarlas. Me puso mal porque justo cuando estaba en esa situación una profesora de esas estaba con una licencia y la otra tenía una licencia por enfermedad.

E: - ¿Y qué le dijiste a la señora?

E: -Yo estaba preocupado viste. Si la encuentra la mata, ¿me entendés? Por eso que no quería que pase. Y ahí se enojó conmigo la señora, empezó, no digo que me quería lastimar a propósito, ¡no! No creo, pero su histeria, viste, empezó a revolear manotazos, manotazos y me golpeó. Yo digo que por ahí tenía un manojo de llaves, no sé. Bueno, fue una situación tensa y lo feo es que los chicos se enganchan mucho en eso. Es como que no toman conciencia de que uno tiene un trabajo, de que uno tiene que mantener una familia, de que no estás de joda ahí. Entonces como que la madre incentivó todo, el chico siempre entró en el grupo con buena conducta, empezaron también a alterar sus ánimos y se empezó a generar una cadena ahí que ya no la paraba nadie.

E: - ¿Y los chicos la alentaban a la madre?

S: -La madre alentaba a que hagan lío los chicos y los chicos alentaban a la madre. De hecho semanas atrás se venía gestando una pelea, en la que los chicos alentaban a la madre a que pelee con la profesora. Por Facebook, ¿entendés? Facebook que tanto ayuda para algunas cosas y tanto te corrompe por otra, bueno... algunos profesores me habían advertido a mí que los chicos estaban mandándose mensajes planeando una pelea, o planeando el ataque de la madre esta hacia la profesora. Ahí es donde empezamos a tomar medidas, cambiar a la profesora de aula para que esté más vigilada. Lo que a mí me duele es que esa profesora que es la que tendría que haberse enterado no se enteró de nada. 


\section{E: -Entonces ¿la profesora no se enteró nunca?}

S: -Sí, porque yo le dije. La profesora creo que tiene derecho a decir "bueno me saco una licencia" o aunque sea bajarse del auto mirando para todos lados, ¿me entendés? Entonces esas cosas son las que un poquito me duelen, como que decir el docente también siente, lo tenés que tener en cuenta. No tener la oportunidad de decir "bueno, hoy no quiero ir porque tengo miedo", ponele.

E: -A mí lo que me duele mucho también es que del grupo de alumnos, uno solo no se haya puesto a separar o a amortiguar la situación. Porque ellos además conviven con vos todos los días, te ven en el pasillo, vos los ayudás, vos les das una mano en lo que podés...

S: -Por eso, se van generando situaciones feas porque uno, a ver... uno cuando tiene que ponerle un límite a un pibe, ¡lo va a hacer! Y cuando vos ponés un límite por lo general no lo ponés con la sonrisa más grande del mundo ¿me entendés? Porque si llegas al punto de tener que poner un límite y ponerte firme es porque vos ya te enojaste también ¿entendés? Entonces uno no puede mentir en eso, uno tiene que ponerse firme. ¡Con respeto! Porque vos no podes faltarle el respeto a un pibe. Uno tiene que ser firme y tiene que mostrar cierto grado de autoridad y no está bueno eso, porque después se siguen generando roces, los pibes se acuerdan y al pibe no le importa si vos tuviste razón o no... a mí me pone mal haberle puesto un límite a una persona, porque después se genera un roce con esa persona. Y por lo general se genera un roce con el grupo; además, muchas veces terminás quedando solo cuando hay algún problema.

E: -¿Te sentiste solo en la escuela alguna vez?

S: -Y, nos ha tocado estar una compañera y yo solamente y tener tres grados. De hecho, el día del problema yo estaba solo con dos divisiones. Entonces era tenso porque cualquier decisión que vos tomes va a estar mal para el inspector o el directivo.

E: - ¿Si pasa algo es tu culpa?

S: -Es mi culpa, por qué, porque yo fui a esperar a una madre y dejé dos divisiones solas. Entonces se pudo haber matado alguno en las dos divisiones y yo hice mal en ir a frenarla a la madre que podía agredir a cualquiera dentro de la escuela. $\mathrm{O}$ yo puedo decir "no, me quedo con las dos divisiones, que entre la madre" y la madre mata a alguno...y yo tengo la 
culpa por qué, porque no fui a frenar a la madre. Entonces cualquier decisión que vos tomes siempre va a estar mal...

E: -Es como una maraña burocrática...

S: -Va a estar mal ¿entendés? Es un poco gracioso, bastante gracioso, depende cómo lo mires. Entonces laburás así, a veces laburás muy tenso. Y sentís que no tenés apoyo y sentís que cualquier cosa que vos hagas lo más probable es que vaya a estar mal para otro ¿entendés?

E: -Bueno te hago una pregunta más de la guía: ¿qué se hace desde la escuela frente a situaciones violentas? En general... qué es lo que suele hacer la escuela.

S: -Primero cuando pasa algo uno siempre apela al sentido común. "Bueno, podemos generar esto, podemos hacer esto otro. O plantear estas estrategias”. Después te das cuenta que el sentido común es hasta cierto punto. Vos tenés un reglamento, tenés ciertos reglamentos, ciertas directivas, ciertos procedimientos a seguir que regulan tus acciones en esas situaciones. Las situaciones de riesgo que se dice. De hecho vos tenés un instructivo que es un plan de situaciones de riesgo.

E: -¿Te referís a la guía federal?

S: -Sí, cierto, esa que está, está ahí en la escuela. Hacia determinados hechos de violencia, por ejemplo, abuso de los chicos, en la casa de los chicos, droga que puedas encontrar en la escuela, situaciones de... estas famosas situaciones de bullying. Vos tenés mucho... ¿cómo decirte? Muchas pautas a seguir. Pero no te dan estrategias, ¿entendés?

E: -Está el papel y arreglate ¿eso querés decir?

S: Claro. Eso. Vos sabes que pasa un hecho de droga y te recomiendan no sé, llamar a algún centro, eh... a algún centro de atención a las personas con, ¿cómo les dicen? Esperá que las tengo acá. ${ }^{5}$ Eh... que las tengo acá porque yo soy el que llama siempre y no me dan pelota.

E: - ¿No te atienden?

\footnotetext{
${ }^{5}$ Mientras hace referencia a los centros de información sobre adicciones revisa su teléfono móvil.
} 
S: -Vos ves que el instructivo este de situaciones de riesgo dice bueno en caso de... ver que un chico que presuntamente está consumiendo sustancias, marihuana o lo que sea viste. Te dice "bueno vos podés llamar al CPA", se le informa al equipo, se llama a los padres con total discreción. ¿Pero qué pasa? Vos llamas al CPA y no te viene porque no funciona en el barrio... ¿En qué estábamos?

E: -Te estaba preguntando sobre cómo se resuelven desde el punto de vista institucional las relaciones conflictivas.

S: -Ah. Vos tenés, el estado te baja este... ciertas medidas a tomar, pero cuando vos querés llevarlas a cabo te das cuenta que no tenés los medios. Por ejemplo, caso de drogas puntuales que nos pasó en la escuela, yo en un recreo encontré a chicos encendiéndose tremendo porro. Todo lo que tenían lo pusieron en ese porro, ¿me entendés? Entonces qué hago, les saco el cigarrillo, los llevo a dirección, se lo muestro a la directora, todo sin estar haciendo mucho espamento para que el resto de los chicos no se den cuenta. El resto de los chicos ya sabían. Disimuladamente los llevo a dirección, les hablo, hago un acta porque tenés que hacer un acta porque si vos vas a actuar tenés que tener un fundamento de que actuaste. Llamo a los padres, los padres vienen y vos tenés que hablar todo como que "aparentemente" se encontró algo que "aparentemente" es un porro. ¡Entonces no te sirve eso! No hay un hecho clave para poder actuar. Todo apariencia, y sobre las apariencias no podés hacer nada. Entonces ese punto, empezando desde ahí ya se te dificulta. Después, tenés que llamar a un CPA, llamás a un CPA no te contestan nunca. Cuando te contestan no tienen personal para mandarlo. Y si tienen personal para mandarlo necesitan autorización del directivo porque va a ir alguien y tiene que tener un pedido de un directivo. Y el directivo nunca firma ese pedido, nunca va. Entonces yo me canso de llamar dos, tres veces esperando un directivo que vaya, que nunca va. Tratas de derivarlo al equipo de orientación, al asistente social, al gabinete. Y el gabinete, ¿qué te dice? Que no se van a meter en eso, porque en temas de droga tienen miedo. Eso es lo que a mí me dijeron en una reunión que yo tuve en biblioteca, solos los tres. Las dos de gabinete y yo. Entonces queda ahí, ¿entendés? Queda un acta que yo hago y le muestro a un directivo que un directivo nunca firma. Donde vos tenés que poner "supuestamente marihuana" cuando yo sé lo que es la marihuana, yo no consumo marihuana pero yo sé lo que es la marihuana. Y cuando 
ese porro tendría que haberse guardado y el directivo para no tener problemas, ¿qué hace? Lo rompe en mi cara, lo tira. Y después me dice a mí que lo rompió porque no se dio cuenta. Y lo rompió porque si lo guarda está obligada a mandarlo a analizar. Porque el reglamento te dice eso, que vos tenés que mandarlo a analizar. Y cuando está todo seguro de lo que es, ahí vienen otros pasos ¿me entendés? Al final es más fácil no haber visto nada (se ríe) o fumártelo vos con los pibes, vas a tener menos problema.

E: -Sí, te entiendo...

S: -Claro. Entonces son tantas cosas que vos te das cuenta que en vez de ayudarte te joden, te perjudican, ¿entendés? Desde ya partiendo de este reglamento que te bajan, los directivos que lo toman como quieren ellos al reglamento. Hay algunos que se juegan y otros que no.

E: -¿A qué reglamento te referís?

S: -A... al plan este de situaciones de riesgo por ejemplo.

E: - ¿A la guía federal de situaciones?

S: -Te baja una cosa que vos te das cuenta que es muy difícil de aplicarla al $100 \%$ porque los tiempos no te dan. Porque vos no podés estar esperando a que el porro vaya a ser analizado en tal lugar, y que en tal lugar después te digan que sí es un porro, ¿entendés? Que no te lo dicen a vos directamente, vos le decís al inspector, el inspector le dice a tal otra persona, y después tal otra persona lo analiza y dice al inspector y el inspector cuando tiene tiempo se lo dice al directivo y el directivo si quiere te lo dice a vos, ¿me entendés? Y mientras tanto el pibe se sigue drogando. Entonces es complicado. Y todas esas cosas te dan bronca, entonces vos decís ¿la escuela te está cuidando? ¿El sistema educativo te está cuidando? No, no te está cuidando. El sistema educativo aparenta que te cuida. Porque si te cuidaran vos tenés un CPA enseguida. Vos tenés que tener un equipo que no le importe correr un riesgo porque tiene que haber alguien que respalde a ese equipo también. Y va a haber docentes que no le importe jugarse porque se van a sentir respaldados. Pero como eso no pasa, entonces uno mira para otro lado y hace su jueguito solo. Entonces cuando vos hacés algo te convertís en el líder problemático, el quilombero.

\section{E: -Entonces no podés hacer nada...}


S: -Vos lo que querés es hacer. Pero si no te ayuda en realidad más que hacer estás generando un quilombo porque qué estás generando, discusiones entre todos los docentes, ¿entendés? Malestar. Entonces vos podés hacer si estás acompañado. Si vos no estás acompañado a veces yo no sé si es mejor callarse porque terminas generando quilombo. Y sin solucionar nada. Terminás generando malestar entre los directivos, entre el inspector, entre tus compañeros, entre los alumnos. Y no solucionaste nada. Entonces esas cosas son las que veo que no... no están funcionando bien. $\mathrm{O}$ el hecho de que un docente tiene que estar cuidado ahí. ¿Por qué yo tengo que cuidar a los pibes nada más? Y por qué no puedo cuidar a mi compañero o el inspector se preocupa por los pibes y no se preocupa por mí.

E: -¿Vos decís que tenés que estar cuidado por el inspector?

S: -Cuidado por el sistema. El sistema es... todo, del directivo hasta el inspector y arriba, ¿me entendés? Y más arriba. Y cuando votas una ley que te contemple a vos, no contemple al chico nada más... ¿por qué si en la escuela estamos los docentes y los pibes, siempre todo es para el chico? ¿Por qué siempre el chico tiene que tener la razón en todo? ¿Por qué el profesor tiene que calificar como se le canta al sistema? ¿Por qué hay que seguir dando 20 mil mesas de examen? ¿Por qué? El profesor tiene derecho a desaprobar a alguien si ve que no alcanzó todos los contenidos. Si el que voto una ley no es el especialista en matemática ni en físico química, ni nada; no es profesor. Entonces por qué hay que decirle al profesor "vos tenés que aprobar a tal pibe, no hacerlo repetir". Entonces yo me doy cuenta que el sistema no está hecho para, no está hecho contemplando a los docentes. Y tampoco está hecho contemplando a los pibes.

\section{E: -Por lo que pasó con el porro por ejemplo, la escuela no hizo nada...}

S: -Lo único bueno, no se fumaron el porro en la escuela. Porque yo pasé a ser el hijo de puta que no quería porro, ¿entendés? Además me preocupó que yo al salir de la escuela venga un auto, estando yo en la parada de micro, un auto se paró y me dijo“¿así que vos sos el preceptor?” Y se me rieron. El mismo día del porro. ¿Entendés? Y nadie dice nada. Yo fui cagado a la escuela un par de días, porque no sabía qué onda hasta que vi que no pasaba nada y está bien viste. Entonces te das cuenta que no tenés respaldo, de nadie. Yo te sigo hablando de estas cosas porque la verdad que a veces me salta viste... 


\section{E: -Hablá tranquilo que la información que brindás es muy útil...}

S: -También la burocracia la tenés en todos lados. ¿Quién se tiene que encargar que la escuela sea un lugar de sabiduría y de trabajo? ¿El estado? ¿Y el estado a quién nombra? Al consejo escolar. ¿Y el consejo escolar va a la escuela seguido? Nunca los ves. ¿Por qué? Porque no tienen tiempo, porque no tienen personal o no tienen presupuesto para hacer lo que tendrían que hacer. Por lo tanto, en pleno invierno te faltan las estufas, tenés un aula con 3 vidrios rotos que se llueve y tenés el cielo raso que te gotea, que te llueve adentro del aula. Y entonces vos decís, ¿qué tengo que hacer? ¿Ir y arreglarlo yo? Nosotros este año tuvimos una donación de eh... ¿cómo te puedo decir? De materiales de electricidad, lámparas, enchufes, alargues, cables. Bueno, lo donó el papá de un chico de tercero. Tiene una casa de electricidad bastante conocida, agarró y donó. Bien, perfecto. ¿Eso está colocado?

\section{E: -No me digas que no está colocado.}

S: -Se hizo el inventario de la donación, todo está guardado, pero no está colocado. Esos chicos no lo aprovecharon este año. ¿Por qué? Porque vos le tenés que decir al consejo escolar que te donaron eso y la gente del consejo escolar tiene que venir e instalarlo, ¿entendés? Y ver si la llave que te donaron para encender la luz y tal y tal cosa realmente condice con lo que estipula el reglamento que tiene que haber. Vos no podés poner cualquier lamparita.

\section{E: -O sea que la burocracia atraviesa hasta las donaciones...}

S: -Sí, hasta las donaciones, ¿entendés? ¿Qué genera eso? Malestar de los pibes contra uno. ¿Por qué? Porque decían que se había robado todo... ¿Pero si llega a pasar algo? Enciende un pibe la lamparita y revienta la lamparita y le quema la cabecita, ¿y culpa de quién es? Del preceptor que lo instaló, ¿me entendés? Entonces vos te tenés que comer el tiempo esperando, haciendo reclamos, mandando cartas, todo, que venga alguien del consejo y te instale lo que te donaron. Porque no te instalan lo que el estado te da; instalan lo que dona un privado. Y mientras tanto vos tenés una entrada de luz con todos los cables afuera, que teníamos en tercero todos los cables afuera, y no importa si el pibe lo tocó y se quedó pegado. Porque la culpa la voy a tener yo que lo tenía que estar cuidando, ¿me entendés? 
Entonces esas cosas son hechos de violencia, el chico que vaya a una escuela y la vea toda sucia, la vea toda escrita, porque son ellos mismos los que rompen todo, ¿me entendés? Y se dan, algunos se dan cuenta, otros no. Otros están acostumbrados a que vos le tenés que dar todo. Y no cuidar. Por qué, porque rompen y saben que tarde o temprano se va a conseguir, que no va a salir de su bolsillo. Entonces unollega un punto donde termina siendo cómplice de toda esa burocracia tonta... te ponés a pensar y uno se pelea con los pibes para que no rompan las cosas, cuando lo que tendríamos que hacer es perder tiempo y pelear contra el consejo escolar. Esas son las cosas las que te terminan distorsionando la cabecita un poquito... ¿De qué estábamos hablando?

E: -Igual arrancamos por otra pregunta si querés, con la que sigue ¿Quiénes suelen ser los protagonistas de las situaciones de violencia en la escuela?

S: -Para mí los chicos, bueno. Lo ves en todos, hombres, mujeres, en todas las edades, lo ves en los adultos. Pero a mí lo que me tocó, más que nada me toca con adolescentes hombres. Son más los adolescentes porque están las hormonas, es la edad. Yo lo entiendo. Lo que yo no entiendo es la violencia extrema. Eso ya sobrepasa un poco a lo natural, lo evolutivo, que tiene que ver con otros factores sociales donde te alejás de los padres, o mismo el maltrato de los docentes hacia ellos. Y ellos se revelan, es como que siempre hay una rivalidad, es como que los tienen de enemigos. Cosa que no debería ser así pero por lo general lo veo en hombres. En los hombres adolescentes veo siempre las situaciones más graves de violencia.

E: ¿ ¿Tienen de enemigos a los profesores?

S: -Eso es todo un desafío. O sea entre ellos el desafío.

E: -¿Crees que la violencia es un problema social que afecta a las escuelas?

S: -Es el reflejo. Porque cuando vos ves un lío, un problema en la escuela y llamás al padre, vos ya estás viendo por qué, ¿entendés?

E: - ¿Es como que el padre reafirma?

S: -Como que te reafirma a vos lo que pensabas. Vos ves un chico violento y citás al padre, después seguramente el padre lo más probable es que sea igual. De hecho lo vemos 
siempre. Hemos citado a padres de chicos problemáticos y no van nunca, o cuando van, van de mala gana. Cuando vos les decís lo que no les gusta escuchar te agreden. Para mí la escuela es el reflejo de la sociedad, la escuela es una sociedad chiquitita, y yo creo que hasta que no cambie, hasta que no cambiemos nosotros la manera de comportarnos afuera no va a cambiar la escuela. Son muchas cosas. Hay muchas cosas que para mí están podridas. Yo me pongo a ver televisión y a mí me van a decir que soy re... chapado a la antigua, qué sé yo, pero a mí ver un programa donde se putean, por más que yo te esté, yo estoy hablando con un amigo y estoy puteando ¿entendés? No soy de decir muchas malas palabras, pero las digo a veces. Cuando vos estás en un programa de televisión para mí tenés que cuidar esas cosas porque te ven todos. Yo nunca me voy a tomar una cerveza ni me voy a fumar un porro en el medio de la calle. Porque para mí no está bien, porque no estás dando un buen ejemplo. Y los chicos están, los chicos de las escuelas, los que tenés en el aula están en la calle.

E: -Bueno te sigo preguntando dale: ¿hay equipos de orientación en la escuela? Creo que me dijiste que sí...

S: Sí, tenés uno que es compartido. Es de la primaria, en realidad a nosotros nos tendrían que nombrar uno, lo que pasa que la escuela eh... dependiendo la matrícula que vos tengas te nombran o no. Como la escuela es chiquita entonces no te nombran. Lo que pasa que vos tenés una escuela chiquitita pero con muchos problemas, entonces se necesitaría. Estamos trabajando con uno que es de la primaria. Tampoco podés pedir mucho porque no conocen la situación del secundario porque están una sola vez a la semana. Están una vez a la mañana y una vez a la tarde, entonces con eso no podes hacer mucho.

E: -¿Y qué es lo que hacen? ¿Cómo actúan?

S: -Lo que tendríamos que hacer nosotros es trabajar siempre en equipo con ellos. Y lo que pasa es que no podes tampoco trabajar en equipo con ellos porque, o están con los problemas de primaria o están con otras escuelas, o están haciendo un curso. El día que tendrían que estar muchas veces sacaron licencia... justo el día que tienen que estar con nosotros, entonces tienen un montón de trabajo atrasado. Y no se puede trabajar mucho así. Lo que nosotros hacemos es, cuando hay algún problema, como estamos los preceptores siempre con los chicos, entonces nosotros le avisamos al EOE, ellos tendrían que ir a 
visitarlos. El trabajo que tienen que hacer los profesores también, pero los profesores no lo hacen mucho, porque piensan que está el preceptor o no sé qué. Entonces nosotros somos el contacto más directo que ellos tienen, y les contamos los problemas que nosotros vemos, si vemos una situación extraña o algún caso de violencia, que molestan mucho a un chico. Entonces todo se lo derivamos a ellos para que ellos vena cómo, nos reunimos con ellos, después ellos deciden como todos, son los especialistas en realidad.

E: -Y en referencia a lo que pasó con la madre del alumno que te golpeó, ¿hicieron algo?

S: -No. Lo que hicieron fue llamarme y me dijeron que cualquier cosa que yo necesitara ellas eran del gremio, de un gremio que iba a estar para actuar en contra de la madre. Y a mí no me importa actuar en contra de la madre porque la madre en definitiva es una pobre mina que... está loca digamos. A mí me importa que, a ver, la madre no hubiera... o se hubiera medido un poco si ellas hubieran actuado desde el principio de año. Como ellos desde el principio de año se sacan licencia... además no actúan en problemas de drogas porque tienen miedo, o se llevan mal con la dirección, entonces dejaron que pasen muchas cosas. Los preceptores, yo te voy a decir la verdad... a la mañana los preceptores son los que ponen el pecho. Entonces si ellas hubieran actuado quizás esa madre no hubiera saltado, no hubiera pateado la reja y no hubiera golpeado a nadie. Porque ya se tendría que haber trabajado con ese pibe problemático, el cual ellos sabían que venía con problemas... se tendrían que haber hecho otras cosas. A mí no me sirve que me llamen después y me digan... "bueno si necesitás la ayuda del gremio, la parte legal”. Yo le agradezco, hubiera necesitado más que vos hagas algo con ese pibe, con esa familia. Ese es el equipo que vos tenés. Uno también trabaja con otros equipos, ponele el CPA o algunas ONG, siempre estás pidiendo cosas.

E: -¿El CPA qué es?

S: -El Centro de Prevención de Adicciones. Siempre estás pidiendo una autorización de un inspector o teniendo un permiso de un inspector o un directivo.

E: -¿El directivo siempre tiene que mediar? 
S: -Claro. Pero no tenés un margen amplio para manejarte porque siempre dependes de otro. Y uno se queja pero yo seguramente si algún día llego a directivo voy a depender de otro y seguramente alguno se va a quejar de mí.

E: -¿Te acordás que hace poco hicimos una jornada de convivencia? ¿Cuál fue el origen de esa jornada? ¿Qué es lo que había sucedido?

S: -Nosotros tenemos tres divisiones entre mañana y tarde. Tenemos un primero, un segundo y un tercero.

E: -¿Vos estás a cargo de cuál específicamente?

S: -Yo estaba de primero y de tercero.

S: -Los de primero divinos. Segundo y tercero... descontrolados totalmente. Bajaron mucho, porque no sabés lo que era a principio de año. A principio de año era cuando encontramos la marihuana, todo. De hecho iba gente de afuera a venderles. De hecho el tipo que estuvo en la jornada, este mismo tipo, ese les vende a los chicos. Y es familiar de uno de los chicos que yo tengo en tercero. Entonces la jornada se originó un poco por eso. Porque ellos estaban acostumbrados a que se hacía, para el mes de octubre se hacía una jornada de fútbol con la parte de Educación Física, que por lluvia no le dieron el espacio y no se pudo hacer. Entonces conseguimos otro espacio y se pudo hacer algo. Dentro de todo era libre, era fomentar el juego, eh... no estaba tan pautado viste. Más que nada era fomentar el trabajo, el juego en conjunto. O el trabajo en conjunto, ponele. Y...fue por los problemas que veíamos en las divisiones, de constantes agresiones, del individualismo que hay. Y eso generó ese proyecto y otro proyecto que era de mural que al final, porque yo tuve el accidente, no lo pude hacer. A ver, no es que yo no iba porque no quería, era la ART la que no quería que yo vaya (se ríe).

E: -Retomando lo de la jornada, ¿de quién fue la idea?

S: -Fue una idea de una compañera, de la secretaria y mía. De los tres. Porque en realidad eso lo usábamos como pie para poder hacer el otro trabajo de mural. Porque íbamos a trabajar, a partir de eso íbamos a trabajar un poco el mural. Yo aparte venía trabajando en

\footnotetext{
${ }^{6}$ Es preciso aclarar que conocía al preceptor previamente a la realización de la entrevista, mientras me desempeñaba como docente en la escuela por la que fue entrevistado.
} 
los momentos que faltaban profesores y les daba algo de historietas... habían hecho algunos trabajitos de historieta y eso lo queríamos pasar al mural. Y todo apuntando a los valores. Qué lamentablemente después, por todos los problemas que hubo en la escuela no se pudo hacer.

\section{E: -Los mismos problemas de la escuela obstaculizaron un proyecto interesante...}

S: - Los problemas hicieron que no se pueda hacer. Ya habíamos recibido una donación de 5000, más de 5000 pesos en pintura, todo.

E: -Bien, retomando las preguntas ¿qué aporte crees que sería interesante para trabajar la problemática de la violencia? O sea, ¿qué idea, qué consejo respecto al tema? ¿Cómo lo abordarías? Etcétera.

S: -Yo creo que si uno tiene decisión de cambio puede. Ahora si vos sos profesor y decís yo no voy a ir a esta reunión para acordar criterios para trabajar la violencia porque ese día no me corresponde ir a la escuela, es muy difícil que cambie algo. Yo creo que si uno quiere generar un cambio, un cambio que valga la pena, y, todo lo que vale la pena te cuesta algo. Porque si no te costó nada es porque no vale nada. Entonces si uno quiere generar un cambio que valga la pena, está bueno poner algo, está bueno sacrificarse un poquito y sentir que uno sacrificó algo en pos de algo mayor. Para cambiar algo hay que aportar tiempo de cada uno, y sobre todo ganas, solo de esa manera vamos a poder acordar criterios para trabajar la violencia. Yo estaba dispuesto y la otra preceptora también estaba dispuesta a ir a contra turno. De hecho yo me he llegado a quedar muchas veces una hora o más en la escuela porque yo veía que alguien tenía algún problema o no había preceptores, o algo; yo me quedaba para organizar un poquito. ¿Por qué? Porque para mí es importante. ¿Por qué? Porque estoy organizando o tratando de colaborar en una institución que en definitiva va a sacar o buenos chicos o malos chicos. Porque la escuela puede sacar buena gente o mala gente. Yo prefiero que la escuela saque buena gente. Y hay que colaborar en eso. ¿Por qué? Porque esa buena gente o mala gente el día de mañana se va a cruzar con mi hija por ejemplo. Entonces yo quiero que mi hija tenga un buen trato. Yo lo pienso así. Entonces como pienso así, como pienso que yo quiero también andar en la calle tranquilo, ¿entendés? Entonces yo sé que puedo hacer algo en ese lugar, en las escuelas. Para el día de mañana sacar buenos pibes y no delincuentes. Entonces yo creo que uno tiene que poner ganas, 
tiene que poner su tiempo y criterio. Para decir, bueno, para dónde vamos a tirar. ¿Vamos a aprobar pibes por aprobar? Y demostrándole a la comunidad que la escuela aprueba por aprobar a pibes entonces van todos a romper las pelotas, a molestar, a insultar, a descuidar la escuela, a molestar a los compañeros, a maltratar a los docentes: ¿queremos eso? Porque si nosotros aprobamos gente por aprobar el rumor del barrio o la idea que se hace de la escuela es esa, que va cualquiera a hacer lo que quiere total aprueba. ¿Por qué no vamos, nos ponemos las pilas, sacrificamos un año, hacemos un año duro? y los que no merecen aprobar no los aprobemos, pero banquémoslos un año. Y nos lo bancamos todos juntos. Si yo tengo un problema estás vos al lado mío.

E: -Lo que decías al principio sobre el tema del respaldo me pareció fundamental, es algo que apareció varias veces...

S: -Este año muchas personas me dijeron, "bueno, yo los apruebo porque no los quiero ver más. Me los quiero sacar de encima”. Yo la verdad los entiendo. Ahora, ¿por qué no mejor nos sentamos en una reunión antes de empezar las clases y planteamos los problemas? ¿Y si hay que desaprobar este año a varios pibes? ¡Los desaprobamos! Y nos lo bancamos el año que viene todos juntos. Y estamos demostrando en la casa de esos chicos que la escuela no es un lugar para joder. Por lo tanto el padre, cuando te vaya a reclamar algo, te va a ir a reclamar con respeto. Con todo el derecho, porque tiene todo el derecho de ir a reclamar. Porque tiene todo el derecho de decirte algo, pero bien. Entonces se va a acercar a la escuela con respeto; yo creo que eso es lo que hace falta. Bueno y después sí, más presencia de los directivos, más presencia del inspector. Porque a mí no me sirve un inspector, de hecho a mí me parece que los inspectores no tienen que avisar cuando van a la escuela. Tiene que caer de sorpresa, ¿me entendés? Y tienen que ir seguido a una escuela. Y si después te termina perjudicando a vos, porque vos te mandaste justo un moquito cuando cayó el tipo y te vio, está bien, ¿entendés? Porque así tenés que aprender. Tiene que haber coherencia en la escuela, una unión entre directivos y entre docentes. Respaldarse, saber que tu compañero va a estar con vos y que el directivo no es tu enemigo que se va a lavar las manos. Y que al inspector hay que hacerle saber, como con la reunión que yo les planteaba donde fueron todos, o varios, el inspector tiene que ver que están todos ahí. Pensando de la misma manera. Y una sola reunión no va a servir. Pero ya queda algo 
asentado. Dos reuniones capaz que sirven más, tres ya le va a romper un poquito más las pelotas al tipo. Y si le rompe las pelotas es por algo, el tipo no es omnipotente, ¿me entendés? Entonces eso hace que el tipo vea un poco más la situación, y que se mueva un poco más porque sabe que si hubo una reunión, dos reuniones y después hay un problema se señaló, si hay un problema que se señaló que no resolvieron va a tener un quilombo.

E: -¿Qué se charló en las últimas reuniones?

S: -Habíamos quedado en que el portón ese, el portón de atrás tenía que arreglarse. El portón está ahora inclinado así que se cae. Va a pasar algún pibe de esos que son re vagos y se le va a caer el portón encima. Y ahí el inspector se va a tener que ir volando a la escuela a buscar el acta que se hizo y romperla, no sé, quemarla y eliminarnos a todos nosotros para que no digamos que nosotros le avisamos que eso podía pasar. Esas cosas son las que se tienen que saber, ellos tienen que darse cuenta que ellos son responsables nuestros también. Son responsables civiles nuestros, nosotros tenemos que hacerles saber eso. Lo que pasa que todo el mundo tiene miedo. En mi caso no me da tanto miedo porque la educación no es mi única entrada de dinero. Yo gano más acá en una semana de lo que gano en un mes allá. Entonces como tengo eso por ahí tengo un poquito más de libertad en decirle las cosas ¿entendés? Que si al tipo lo quiero mandar a la mierda, se lo digo y renuncio, ya está. Hay que decir un poquito más las cosas.

E: -El miedo es justamente por la pérdida del trabajo, por el sumario y siempre aparece la precariedad laboral en el fondo...

S: -Para mí sí, si yo me siento respaldado por vos, yo voy a actuar como debo actuar, yo tengo a alguien que respalda o que ratifica lo que yo hice. No solamente como docente estás respaldando a alguien, también como persona, eso es coherente como adulto eh...

E: - ¿Y cómo se puede mejorar la relación con los chicos?

S: Hay que salir un poco de esa postura de "yo lo sé todo, soy el profesor". Compartir un momento de recreación con ellos te juega muy a favor también. Está muy bueno eso. Yo ojalá siempre sea así, ojalá siempre tenga espacios para hacer esas cosas. Porque yo creo que es eso en realidad es lo importante.

E: -¿Qué opinás sobre las sanciones? 
S: -A mí... me tienen cansado cuando dicen que la escuela tiene que ser inclusiva. Para mí una escuela inclusiva es una escuela en donde todas las cosas funcionan en su eje, como tendría que funcionar. Porque las cosas que ves lindas en el papel a mí no me sirven para trabajar. Uno a veces también tiene que sentir la pérdida de oportunidades. Si ves que el pibe se manda la macana entonces vos le haces un llamado de atención, una amonestación, dos, tres hasta que llegás a citar a los padres. Los padres por lo general no te respaldan, los depositan en la escuela y siempre le dan la razón a ellos. Termina suspendiendo. Ponele que el pibe tiene tres días de suspensión y a los tres días vuelve a ir. ¿Qué hizo el pibe? Tuvo tres días de vacaciones. Y el profesor del pibe que faltó a clase no le exige que recupere. Entonces no te sirve de nada la amonestación, son tres días de vacaciones porque ni siquiera planteaste con el profesor que después le va a tener que dar una tarea para que recupere las clases que perdió. Eh... todos los contenidos y se lo decís al profesor, pero el profesor tampoco tiene tiempo de planificar. O uno también, a mí me pasa que yo capaz que digo, digo, digo pero tampoco me ubico en el lugar del pobre tipo que está lleno de horas también para vivir. Entonces para mí es fácil decir lo que tiene que hacer, pero hay que estar en el lugar del tipo, ¿me entendés? A mí se me ocurren cosas, pero una cosa es que yo se las diga y otra cosa es que él las haga. Y que ya te digo lo entiendo porque tiene 20 mil cosas. Entonces a mí no me sirve el sistema ese en que vos podés llegar hasta la amonestación. Expulsiones no hay, pero para mí tendría que haber. A mí me pueden decir "vos sos un hijo de puta, a vos no te importa sacar a un pibe de la escuela". Yo prefiero sacar uno y que no se me vayan diez. Porque ha pasado cuando pasó el tema de la droga, esos que llevaban la droga siguieron estando molestando todo el año y muchos buenos pibes se fueron. Se fueron varios buenos pibes por ese tema de la droga y los padres fueron a quejarse por ese tema puntual y que por eso los sacaron a los chicos. Entonces no me sirve seguir reteniendo gente, yo prefiero el sistema antiguo de expulsión, y me pueden decir "ah pero sos un hijo de puta porque no estás incluyendo nada". No, para mí el que se manda una macana tiene que sentir en algún momento que perdió algo. No lo va a sentir en el momento pero va a pasar un tiempo, unos años y se va a dar cuenta que perdió algo. Y quizás no va a reaccionar en el momento que tiene que reaccionar; capaz que años después. Para mí debe ser así. Porque tampoco te sirve ese famoso sistema inclusivo que hay ahora. No es inclusivo en términos de educación. Lo que se está haciendo es esconder todos los 
problemas. No es inclusiva porque si fuera inclusiva el pibe que tiene problemas vos lo mandás a un psicólogo o algo y no lo estamos haciendo. Lo estamos suspendiendo, pero no podés suspenderlo indefinidamente. Si vos lo pateás todo y no solucionás el problema, le demostrás a todos los chicos que pueden hacer lo que quieren, porque les van a dar tres días de vacaciones y después vuelven a hacer quilombo. Entonces no te sirve, yo prefiero realmente una expulsión, que el pibe sienta que perdió algo, que al padre se le complique la vida. Y yo no te digo que esto es una solución, esto es sacarse también un problema de encima. Pero yo prefiero sacarme un problema de encima a que se me vayan cinco o seis buenos. Y ya te digo, sonará de hijo de puta, sonará mal, qué sé yo, y si yo lo veo fríamente tampoco está bien. Tampoco está bien, pero si se me van a ir cinco o seis yo prefiero hacer un mal menor. Dejémonos de joder tanto con la escuela inclusiva. Porque si la escuela es inclusiva tenés que generar el espacio para ese chico problemático. Y lo que estás haciendo es ponerle un muro, además los mismos pibes terminan rechazando a ese pibe. Entonces ese pibe termina sintiendo el rechazo del resto, de los buenos pibes y de los docentes. Porque vos sos humano y quieras o no la cara de rechazo se te nota.

Y que no me venga a discutir un inspector o quien sea que yo tengo que actuar de otra manera, porque vos sos humano y te sale a veces. Y si no yo quiero ver al inspector en mi lugar recibiendo puteadas todos los días a ver si no le pone cara de orto a los pibes. Entonces para mí el sistema, como está ahora el régimen de amonestaciones, de infracciones, no sirve. No sirve porque termina desprestigiando a la escuela. Y no me sirve a mí eso. Y está mal lo que yo te propongo, está mal porque termino sacándome un problema de encima.

E: - ¿Es como que una medida determinante atentaría contra el actual paradigma de escuela inclusiva?

S: -Va en contra, pero no hay escuela inclusiva ahora.

E: ¿¿Creés que la escuela no incluye?

S: -Es más, creo que la escuela hoy es menos inclusiva que antes. Porque antes había valores, ¿entendés? Entonces todos tenían interiorizados ciertos valores que hacían que una escuela sea una escuela. Y el que iba a esa escuela respetaba; incluso el más hijo de puta 
tenía miedo de mandarse una cagada. Porque respetaban esa escuela. Esa escuela daba autoridad, los docentes daban autoridad. Entonces solos se auto incluían, solos se ubicaban en las normas. Entonces esta escuela que yo veo ahora no es inclusiva, para mí no es inclusiva, es mentira que es inclusiva. Y para mí sí está mal que se diga que hay que echar y expulsar al que molesta. Para mí no está bien porque también estás dejando de lado un problema, estás como castigando al chico. Porque en definitiva también es un castigo para el pibe. Pero otra no te queda. Y para mí esos castigos a veces también un poquito sirven, para algunos. Porque te hacen pensar, porque el hecho, uno si no pierde no cambia. Si vos no sentís que perdiste algo no generás cosas nuevas para recuperarlo o para ganar más. Para salir de tu estado actual. Uno tiene que sentir que perdió algo, tiene que sentir el esfuerzo, el sacrifico. No sirve...

Sabés una cosa que te digo, en realidad todo el mundo piensa como yo. Mirá, yo creo que la gran mayoría piensa como yo, pero como hay ahora una moda de la inclusión y del pobre que menos tiene... pero yo creo que a veces el que menos tiene se buscó tener menos. No en todos los casos. Entonces yo te digo lo que capaz piensa la mayoría. Porque yo creo que la mayoría piensa, de hecho vienen muchos docentes acá, con muchos docentes me quedo hablando acá. Todos piensan como yo y después te dan otro discurso. Algunos, otros no. Pero para mí la escuela tiene que retomar un poquito lo que era antes, en parte.

E: -Bueno te hago la última pregunta. Después si vos crees que hay que agregar algo me decís. ¿Qué rol crees que juegan los medios de comunicación en el problema de la violencia?

S: -Y, es lo que yo te dije hoy ponele, el tipo que, vos tenés a Tinelli mostrando un orto, está bueno verlo. Pero vos ves una mina bailando y el tipo como hacía hace unos años atrás que le cortaba la tanguita viste, mostraba el culo, la tenía como un pedazo de carne, a mí me gustaba ver ese orto, ¿me entendés? Ahora, no me parece que eso a un pibe que se está formando le sirva, ¿me entendés? No me parece. No me parece que en un programa de televisión se esté discutiendo, y capaz que yo sueno muy antiguo, muy facho, lo que quieras. Pero no me parece que en un programa de televisión tengan que estar discutiendo si la droga tiene que ser penalizada o no. Porque para mí es algo nocivo y tiene que estar penalizada. Hay muchos programas que si vos no los controlás o dejás que el pibe los vea 
sin un adulto, sin una persona que tenga experiencia, pueden ser un arma de doble filo. Está bueno un debate de la droga si tiene que ser despenalizada o no. Está bueno. Pero si el pibe lo ve solo no sé si está bueno porque no va a poder entender todos los pro y los contra. Para eso yo creo que necesita un adulto al lado. No creo que solamente son los medios sino... porque los medios están. Los mass media están. Y van a estar siempre. Y peor todavía porque el loco, antes, viste, yo tenía el celular este y me servía para mandar mensajes de texto. Ahora yo tengo el celular este y tengo internet. Tengo internet y tengo el Facebook y si quiero me meto al google y en el google tengo todas las páginas porno que quiera. Y entonces... y esto lo tienen todos los pibes. Entonces si vos no tenés control sobre lo que los chicos usan, los celulares o internet o el Facebook, entonces no sirve. Yo creo que todos los medios sirven en función de que vos lo acompañes. Creo que lo que hacen es, uno tiene que decidir a ver qué ejemplo quiere dar. A mí me duele a veces programas que yo veo, a ver se me ocurre alguno en especial, sí yo veía a veces, no porque me guste la cumbia, no me gusta la cumbia. Pero veía a veces porque me divertía un ratito, un sábado viste. Y daban por ejemplo Pibes Chorros. A mí la música, no me gusta la cumbia pero me divertía escuchar un poquito el ritmito. Ahora, si yo soy más pillito y me pongo a escuchar la letra yo me doy cuenta que hacen apología de la droga. Tengo otro, el chaboncito de La Liga. Lo único que hace es vivir hablando de la droga y viva la joda y los pibes vagos, o la mala fama. Es la apología de la delincuencia y de la droga. Ahora, vos me decís, ¿está bien que un programa de televisión muestre eso? A mí me parece una canallada que un programa de televisión muestre a un tipo cantándole a un delincuente, cantándole a una droga, al libre consumo, y "qué bueno que salimos de vagancia en la noche". Y no nos rescatamos, no sé las letras que tienen. Todo con jerga carcelaria, y que te incita a hacer lo que no es bueno hacer. Porque a mí nadie me saca de la cabeza que fumarse un porro no es bueno. Porque yo he visto casos de gente, de hecho una amiga muy, muy íntima que empezó en el recital de reggae con el porrito, el porrito, el porrito, y después yo la tuve que dejar de ver porque era cada vez peor, y a mí me incomodaba hablar con ella porque yo no sabía si estaba hablando con mi amiga lúcida o con mi amiga drogada. Porque hasta en los momentos de lucidez ya había quedado mal de la cabeza, ¿me entendés? No solamente la droga, no solamente la marihuana, de la marihuana había empezado a probar otras cosas. Entonces para mí está mal eso. Y un tipo que hace apología de eso o que hace apología que hay que 
salir de caravana a la noche, de caño, como varias canciones que he escuchado que apuntan directamente a la delincuencia... no me parece que un programa o un canal de televisión permita eso, a mí me parece lo peor. Porque yo soy grande y sé que eso no lo voy a hacer. Pero el pibe de secundaria...

\section{E: -No hay nadie que le diga que eso no hay que hacerlo...}

S: -No. Entonces yo creo que ahí es donde jode. A mí me duele porque yo veo que importan muchas cosas. Porque ahora se le dio la moda del reggaetón. Y yo conocí muchos, porque yo viajé como por 16 países. Bueno, el reggaetón es música de maras Es la música de ellos, ¿entendés? Que ahora estamos nosotros escuchando. Y los pibes no saben eso, no saben. Piensan que es reggae con...

E: ¿¿Con otra base?

S: -Con otra base. Y es música mara, que nosotros importamos. Y vos ves a los pibes que se sacan fotos en el barrio y los simbolitos que hacen con las manos y esas son señas de maras. Y yo te lo digo porque yo trabajé en México, en lugares donde estaban las maras pintando, y es la forma de expresarse de ellos. Es la música de ellos que nosotros importamos y la estamos tomando como una moda pero es la entrada que ellos tienen. Pero no te escuchan nunca un Larralde. De hecho le pregunto a los chicos: ¿no escuchan Larralde? ¿Qué es eso, Larralde? Y no, escuchan esto, porque esto es lo que va. Y si vos te pones a escuchar folklore te vas a dar cuenta que es música más rebelde, más fuerte que eso. Es música bien pesada el folklore para mí. ¿Vos querés rock pesado? Bueno, tenés Larralde.

Uno vive importando cosas, ejemplos que para mí no son buenos. Pero por qué los importan, porque son los que hacen que no pienses, que vos te dediques a la joda. Al que está arriba le conviene más que todos escuchen a un tipo que habla de la droga y de la joda, que no pienses, entonces el que escucha eso dice bueno hablan de la droga, de la joda, lo dice aquel, lo dice ese. Si lo dice el de la televisión, que es más que yo porque está en la televisión, entonces está bien. O sea que yo puedo hacerlo porque él, que es más que yo porque está en la televisión, lo hace. 


\section{Entrevista a preceptora $y$ profesora de teatro perteneciente a la "escuela de la periferia norte"}

Nombre ficticio: Antonella

Duración: 39 minutos

E: ¿QQué cargo estás ocupando ahora? ¿Cuánto hace que trabajás en el sistema educativo?

A: -En el sistema educativo hace 25 años que trabajo. Soy preceptora, fui maestra y bueno, trabajé como profesora de teatro en escuelas primarias. Ahora no trabajo más como profesora de teatro.

E: -Y en la [escuela de la periferia norte], ¿qué cargo tenés específicamente?

A: -Preceptora.

E: -En ese cargo ¿hace cuánto que estás?

A: -Desde el 2008... seis años como preceptora.

E: -Te cuento, yo te elegí a vos como informante porque vos tenés, desde mi punto de vista, otra relación con los chicos. Les das la opción a ellos de que participen de actividades alternativas.

A: -Es cierto. Me acuerdo que cuando yo fui con la idea de ir al Encuentro de Jóvenes y Memoria, me miraban y nadie hablaba. No sabían lo que era. Ni siquiera les entusiasmaba la idea de hacer un viaje. Entonces, como no sabían que era Chapadmalal, les decía "a Mar del Plata, pasando Mar del Plata, a la playa”. Hasta que de a poquito les fui contando. Me fui acercando... y no eran mis chicos. Los míos son de primero, los más chiquitos. Yo trabajo mejor con los más grandes.

E: -Lo que significaba más compromiso para vos todavía...

A: -Sí, porque me gusta. Es aburrido el trabajo de preceptora, de pasar lista, pasar boletines y todas esas...

\footnotetext{
${ }^{7}$ El nombre de la institución fue omitido para preservar la identidad de los informantes.
} 
E: - Claro, mucho administrativo...

A: -Yo creí que me moría cuando agarré el trabajo de preceptora, dije "bueno, debe ser más liviano si no estoy en contacto con los chicos". Pero a mí me gusta trabajar con los chicos. Estaba agotada de los niñitos y le tenía un miedo terrible a los adolescentes... pero me encantó. Me encantó acercarme a ellos y que te cuenten... ellos confían en mí. Así pasó lo de esta chica, confió en mí a través del trabajo teatral, se hizo el vínculo, el grupo. Eso es lo que tienen los grupos de teatro. Nos conocimos y me contó. En realidad le contó a una amiga y esa amiga me contó a mí y explotó. La escuela no intervino a tiempo porque yo avisé pero tuvieron mala suerte porque yo conozco a un asesor que está en el distrital. En realidad en la escuela no me daban bolilla. Hacía bastante que estaban abusando de esta nena, que después me contó todo, desde los 9 años, con lujos de detalles, un hijo de puta el tipo. Y por otro lado, yo sabía que... ante una presunción de un abuso hay que hacer la denuncia porque es un delito penal. Entonces me dijo "llamá a la escuela". Llamé a la escuela, me comuniqué con el gabinete, el gabinete... [En tono burlesco] "ay, sí vamos a entrevistar a la madre". Procedieron mal porque lo que hay que hacer es apartar a la piba. Bueno, hay otro procedimiento antes... hay que hacer la denuncia policial, eso es lo primero. Bueno, no la hicieron y entonces intervino la distrital. Y ahí se les armó el quilombito y yo fui a denunciar. Bueno y de ahí el director me tomó un odio terrible porque denuncié primero. Y bueno, ahí en la distrital me asesoraron, me dijeron que había hecho bien, me decían "es una denuncia penal, si vos te enteraste de eso tenés que hacer la denuncia”. Además, la piba estaba sufriendo. El problema es que no a todos les importan los pibes, que no los quieren.

E: -Claro, el tema es cómo convivís vos también con esa carga porque una vez que vos te enteraste, te involucraste, denunciaste, ¿y después?

A: -Tenía que contener a la chica porque a la chica la tenía acá todo el tiempo. Y la mamá mucho no comprendía, primero lloraba y lo iba a visitar al tipo a la cárcel, todavía está preso... y este año me tomé licencia sin goce de sueldo un poquito para alejarme también.

E: -Sí, es totalmente entendible.

A: -Además, estaba media paranoica. Si sueltan al tipo voy a ser a la primera que buscan. 
E: - Claro.

A: -Otra vez me pasó con un embarazo... también, acá en teatro. De golpe no viene más la chica. Y digo “¿qué le pasa?”. De repente yo la miraba, “Ay qué fea que está esta chica. Está engordando, qué raro", pero yo no me daba cuenta que tenía panza de embarazo. “¿Estás hinchada?”, yo le digo... “¿fuiste al médico?”. “Tenés retención de líquido, ¿qué te pasa?". Y de buenas a primeras no vino más. Tuvo un bebé y bueno, yo avisé a la escuela. La madre dice que no se había dado cuenta tampoco.

E: -Bueno, te voy a hacer una preguntita relacionada con la tesis, después si vos ves que en algún momento aparecen casos que quieras citar como ejemplos... todo es bienvenido. ¿Qué crees que significa el término de violencia? En términos generales, qué es lo primero que se te cruza a la cabeza cuando escuchás la palabra violencia.

A: -Un grito, un golpe... un eh... ignorarlos. Bueno, yo porque lo relaciono con los pibes, el maltrato verbal, el... Y siempre desde el adulto y no desde la familia, es la institución.

E: -O sea, que vos ves que la violencia, en el caso de las instituciones educativas, ¿está generada por los adultos hacia los alumnos?

A: -Sí, lo veo. Algunos lo disimulan... cuando están solos son de una manera, cuando hay otra persona: “a ver mi amor, vení".

E: -Una pregunta que quizás suene algo básica a esta altura: ¿vos creés que existen situaciones de violencia en la institución educativa?

A: -Sí.

E: -Y ¿podrías recordar algún hecho puntual que puedas mencionar? ¿Algún acontecimiento que recuerdes?

A: -De maltrato verbal, sí. Una profesora a una alumna, la maltrató mal. No me acuerdo qué insulto le dijo pero sé que maltrataba porque no era la primera vez que maltrataba a alumnos. Cuando estaba en el Anexo $1,{ }^{8}$ por ejemplo decía "qué olor que hay acá, no se

\footnotetext{
${ }^{8}$ Hace referencia a una parte de la escuela secundaria que funcionó varios años en otro edificio (compartido con una escuela primaria).
} 
bañan", y después viene y comenta "acá son todas bolivianas, son todas sucias". Y tiraba desodorante para el olor, “qué feo olor”. O prendía sahumerios.

E:- ¿Y recordás algún hecho de violencia por parte de los alumnos? ¿Recordás algún caso que haya sucedido en la escuela?

A: -Sí, ellos se pelean mucho, son como códigos entre ellos. Las miradas: “¿por qué me mira?". O son bandas, o porque me dijo... porque no me dijo. Entonces, con un teléfono descompuesto van y te quieren re cagar a palos, ¿por qué? Porque me miró feo. Y le han dado una piña, por ejemplo, a una alumna mía, hace un año acá en el anexo 1, porque otra la miró feo... en un principio nos enojamos mucho porque le dije de todo. Hasta la madre de la que pegó se enojó conmigo. Pero después cambió. A veces empiezo siendo un poquito agresiva con los chicos y después los empezás a conocer... ves que los querés, y no los podés tratar mal.

E: -Claro, fijate qué interesante lo que me decís... una vez que vos conocés a alguien, cuesta tratarlo mal.

A: -Y lo que se daba con los trabajos, cuando los llamo para trabajar en el teatro, después de que se aflojan, que trabajaron una escena y todo eso, se puede establecer un vínculo y charlar las diferencias. Una vez que establecés el vínculo... lo podés hacer con un grupo nada más. Después ves que los demás se contagian: “Ah yo también quiero". Pero llega un momento en que no podés incluirlos a todos. A mí no me dan los tiempos. Y la escuela no valora nada de eso. La escuela eh... si pudiera sancionar, sanciona. Como que no los escuchan. No sé qué onda con la escuela.

E: - ¿Cómo crees que tendría que actuar la escuela frente a acontecimientos de violencia?

A: -Primero hay que dialogar con los pibes y después llamar a los padres. Pero hay que hablar, ver cuál es el problema, tratar de resolverlo y escucharlos... porque nadie los escucha. Nunca enfrentarlos, porque vos querés resolver un problema entre dos, llamás a los padres y es peor. Está el padre con el alumno, queriéndose agarrar entre todos.

E: -¿Te ha pasado algo así? 
A: -Sí, ha pasado así. Dos chicas se mandaban mensajes de texto por el celular, "que te voy a cagar a palos y esas cosas", y... entonces vino la mamá de una, furiosa, a buscar a su hija porque esta otra le iba a pegar. Entonces viene la madre de la otra y se armó un quilombo en preceptoría terrible. Una gritaba y la otra gritaba, estaban las cuatro, las dos hijas y las dos madres. La mamá de una alumna... pero me vino a ver a obras de teatro. La traje a la comunidad, sí. Dos familias vinieron a ver obras así por cuenta suya, de acá. ${ }^{9}$ Y yo no le cobro. Que vengan a ver una obra de teatro es ¡Aah!

\section{E: -Debe ser un logro imagino...}

A: -Sí porque sus hijas entonces después vinieron a verme a mí. El año pasado vino la familia de una alumna. Vino a ver El Despojamiento con la pareja y me contó cosas. Hasta los padres me cuentan cosas de su vida privada. Yo no sé qué hago...

E: -Bien, entonces, otra pregunta de la guía: ¿quiénes creés que son los protagonistas de los hechos de violencia?

A: -Para mí los más violentos son los docentes con la actitud que tienen frente al alumno. Porque el alumno reacciona en respuesta... te rompen el auto, te lo rayan, te putean, te escupen... pero si vos les hiciste algo. Ellos son violentos porque vienen de hogares violentos, pero si en la escuela se encuentran con otro ambiente hostil y a vos que no te conocen, no les importa un pito, "te rompo todo". Había una profesora que era como para desfigurarla cómo los trataba... yo también me pongo violenta con los docentes. Andate a una escuela privada si no te gusta. Los pibes vienen de hogares violentos, son violentos. Pero en la escuela es como que, encima no les gusta ir a la escuela porque no es motivadora para nada. Porque se aburren. Y que un profesor los ningunee o los trate con desprecio, porque lo veo... dan ganas de, yo me pongo en el lugar de ellos y sí, les partiría la silla por la cabeza al profesor.

E: -Quizás esos son los medios que ellos conocen para responder...

A: -Sí.

E: -Frente a un disgusto es lo que ellos conocen...

\footnotetext{
${ }^{9}$ Se refiere a una escuela de teatro barrial que ella misma administra en el fondo de su casa (lugar en el que se desarrolló la entrevista).
} 
A: -Y no hablan, no hablan. El profesor los quiere hacer hablar pero no encuentra el modo de cómo llegarles.

E: -Sí, a mí me ha pasado a veces que hay clases que no pego una...

A: -Sí, a mí también. Hay uno con un yeso que cuando tiene esos días vos decís...

E: -¿Vos creés que la institución genera problemas de violencia por sí misma o de alguna forma los conflictos de afuera son los que explotan adentro?

A: -Ah, esa, qué difícil... puede ser un combo de las dos. Como que la institución por ahí no está preparada o ni los docentes, nadie puede contener a tanto conflicto. Sí, porque me las rebusco con lo que me gusta y me siguen los que les gusta hacer lo que a mí me gusta. Pero si yo tendría que tener clases de teatro y a todos no les gusta, ja, ahí te quiero ver. Por eso dejé de dar teatro.

E: - ¿Solo das clases de teatro de forma particular?

A: -Sí, acá vienen los que les gusta hacer teatro. Terapia, no. Los psicólogos me mandan gente y yo los echo. Porque es como que te manden a hacer, no sé, jardinería y no te gusten las plantas. Yo quiero gente que le guste hacer teatro porque yo pongo todo acá. Por más que garpe... hay que laburar.

E: -¿Hay Equipo de Orientación Escolar en la escuela? ¿O algún otro equipo adicional que trate los problemas que, eh, de alguna forma exceden las posibilidades de control del docente?

A: -Y el equipo, el único grupo que tenemos es el que compartimos con el Anexo 1, hay una orientadora... que es una divina, trabaja muy bien... pero... a veces es como que hay muchos problemas y hay un solo equipo para toda la escuela. Pero en verdad el equipo es del Anexo 1. Con todos los problemas que hay...y bueno, ellas están ayudando, están interviniendo en las situaciones de conflicto...

E: -¿Y cómo suelen actuar estos equipos? ¿Qué acciones suelen llevar adelante?

A: -Mucho diálogo. La orientadora es de charlar mucho con los chicos, solos, entrevistas solos con los pibes. Y de ir a los domicilios, llamar a los padres. Siempre han intervenido 
bien. Y Natalia es, es muy cuidadosa y... tiene ese poder mágico de calmar a la gente. Cuando habla con un padre o con el mismo pibe o piba, depende de lo que sea. Pero el año pasado el otro equipo... no, el otro equipo era muy así, muy este... "vení que te ayudo" y no se siente, cuando es fayuto, es falso, el pibe lo percibe. Y por ahí yo sabía cosas que ellas no sabían.

E: ¿QQué herramientas pedagógicas suelen llevarse a cabo en la escuela para el tratamiento de situaciones violentas?

A: -Sí, el diálogo, el llamado de los padres y la intervención del equipo. Los directivos dejan mucho que desear. La última, bueno, la intervención de la distrital que supieron asesorarnos con ese manual de... ay no me acuerdo cómo se llama ahora...

E: -¿La guía federal para situaciones violentas?

A: - Esa guía, sí. Esa la tengo, fue lo primero que me dieron cuando vinieron las inspectoras.

E: ¿ ¿Escuchaste quejas sobre situaciones conflictivas entre colegas?

A: -Docentes quejarse de los alumnos, sí, todos: “Ay que este chico es retardado, tendría que estar en una escuela especial, no sé por qué está acá, no sé porqué aquel profesor lo aprobó". No sé porqué lo quieren desaprobar, si pobrecito, por más que termine el secundario... no sé qué va a ser de su vida. No se porta mal, hace lo que puede, completa la carpeta, no era un pibe que se porta mal. Hay... profesores que se quejan de los alumnos. Y los alumnos también se quejan de los profesores. O profesores que están a un nivel ahí, muy arriba en contenidos, y no quieren bajar. O dan muchos libros para leer o muy largos... y les cuesta.

E: -¿Qué aporte creés que sería interesante para el tratamiento de la violencia? ¿Qué sugerencia o qué, qué idea creés que podría aportar al problema de la violencia actual?

A: -Yo me voy a ir por las ramas con eso. Primero que quieran a los pibes. Si no hay vínculo no podés hacer nada. Vínculo, diálogo y los contenidos después. Digo, que estés conteniéndolos... escucharlos. Da tu materia pero escuchalo, que vea que al profesor le interesás. Y que si te vienen con algo, aguantátelo y escuchalo a ver qué quiere. 
E: -¿Qué pensás sobre el sistema de sanciones y de las actas? ¿Creés que el actual sistema de sanciones es efectivo?

A: -Si al pibe lo suspenden, mejor para el pibe porque no va a la escuela, no tiene ganas. La única que se preocupa es la madre, "ay me lo suspendieron". El pibe chocho en la casa. Pero bueno, antes que una suspensión, no sé. Que busque otra cosa.

E: - ¿Qué rol creés que juegan los medios de comunicación en el problema de la violencia en las escuelas? ¿Vos creés que... simplemente muestran la realidad, que magnifican los problemas, que los disimulan?

A: -Lo magnifican. Están todo el tiempo mostrándote violencia, violencia, violencia. Existe la violencia, lo ves, las cagadas a palo, las persecuciones, las corridas en la cancha y te lo muestran bien explícito. La seguridad, la seguridad... están todos preocupados por la seguridad. Bueno, hay que andar un poquito más atento en la calle, cuidarte de otra manera, pero hay una paranoia de eso. Vas caminando por la calle y vos creés que vienen y te van a afanar. No sé. Y el que va así lo afanan seguro, me parece que es como un imán. Los medios están todo el día bombardeando. El tema es que muestran mucho, muestran la misma noticia una y otra vez. Te la pasan, te la recontra vuelven a pasar y te la vuelven a pasar. La misma, la misma, la misma...y no paran.

E: - ¿Creés que se puede agregar alguna información adicional a lo que estuvimos recorriendo? ¿Algo más para agregar?

A: -Supongo que no pero bueno, para mí los docentes y la institución es violenta. Desde el padre que viene porque quiere hablar con la directora y la directora le dice: "que venga después", o le dice: "en un rato, que me espere". Como si el padre no tuviera nada que hacer... Y se han generado conflictos de violencia, por ejemplo en las inscripciones. O la escuchás a una colega: "afuera los profesores y afuera los chicos". 


\section{Entrevista a profesor de Construcción de la Ciudadanía y Secretario perteneciente a la "escuela del centro"}

Nombre ficticio: Pedro

Duración: 50 minutos

E: -¿Podría mencionar su nombre, función y experiencia en educación?

P: -Soy secretario y tengo un cursito a cargo. Hace dieciocho años que estoy en educación.

Después tengo veintisiete años en el Servicio Penitenciario en situación de contexto de encierro.

E: ¿O sea que trabaja cotidianamente en los dos sistemas?

P:- Sí, en los dos sistemas. El aporte que puedo hacer es que el sistema carcelario trajo un lenguaje de la violencia. Cincuenta cárceles son escuelas que es la subcultura del delito. ¿Que cómo entronca? Y sí. Fijate vos que los chicos dicen: "gato, gato”. "Estás descansando". Y nosotros sabemos qué es "estás descansando", yo lo vi primero en la cárcel y después lo vi en la escuela. "Estás descansando" y la cárcel es el descanso para ellos, y hay una conexión, culturiza mucho más rápido las cincuenta cárceles que las ciento cincuenta y cinco escuelas en cuanto al lenguaje, que la Real Academia Española me baja culturalmente y la matriz biológica de la erudición, del saber por excelencia de las universidades no llega a la base del pueblo. Porque fíjate, Moreno, La Matanza, San Isidro, millones, millones de personas van. Porque no es solamente el interno que está preso, es también la familia que está esperando el sábado, tres, cuatro horas y nos transfiere a nosotros el lenguaje y lo modifica y se ve en la escuela y además si vos no pertenecés al grupo hay una especie de segregación.

E: - ¿Como una especie de exclusión?

P:-Sí, te excluye y en cierta forma no pertenecer al grupo es estar en inferioridad frente al resto de la clase.

E: -¿Usted cree que en la escuela se vivieron situaciones violentas? ¿Que se viven recurrentemente, ocasionalmente? ¿Han ocurrido hechos violentos en el contexto de la escuela? 
P: -Sí, sí. Por suerte podemos decir que nunca ingresó ningún arma, ni scooter, ni nada de eso. Nada grave. Sí algunos forcejeos dentro y fuera de la escuela. Antes uno se peleaba a tres cuadras de la escuela, pero ahora los chicos lo han traído a la escuela. Lo traen a la escuela, porque es justamente parte, eso de "sacar afuera" todo lo que tenemos, lo bueno y lograr, justamente... la escuela secundaria es una escuela que está educando para la paz. Si algo tiene como objetivo nuestra escuela es educar para la paz, entonces todas las situaciones se van a hablar y a escuchar; y se va a sacar conclusiones para bien o para mal. Entonces todas las clases mías arranco con el eje ético.

\section{E: -¿Qué materia dictás?}

P: -Construcción de la Ciudadanía. Estamos construyendo ciudadanos con una conciencia de la no-violencia y de educar para la paz. Si algo tiene como objetivo nuestra escuela es que educa para la paz. Un mundo mejor sin paz no es posible. Volvimos a los valores para evitar la violencia.

E: -Con respecto al concepto de violencia: ¿crees que existe violencia física, violencia verbal, violencia psicológica? ¿Se pueden agrupar en un mismo concepto de violencia o se podrían tomar por separado?

P: -Sí. Nosotros lo que tratamos de evitar es la violencia física, porque sabemos lo que origina la violencia física. Ahora, si podemos evitar la violencia psicológica sería lo ideal. Y para eso el docente está en un compromiso importantísimo con la violencia. El otro día escuchaba a un profesor que le dijo a una alumna (y sin ponerse colorado): "yo no soy ni tu novio, ni tu marido, hasta que te guste mi materia”. Digo yo, ¿qué tiene que ver el barco con el sol? Y la alumna le envenenó la botella. Pero sí, cómo le va a decir semejante barbaridad a una alumna de doce años. Si mi hija se dio su primer beso con un novio a los diecisiete años, lo sé por sus amigas y por Facebook. ¡Pero cómo un profesor va a decirle eso a una alumna de doce años! ¿Si eso no es violencia? Somos picotazos de Eugenio Cambaceres. Tampoco es, el hombre no sabe, recibió, que no le puso dos toneladas de tóxico para matarlo, le puso un poco para que le agarre una indisposición, le puso unas gotitas y lo avisó antes. Tampoco es que lo mandó a la cámara de gas. Como para decir este sinvergüenza, y además avisó. Lo dijo en televisión y además dijo otras cositas que van en dirección a las del profesor y yo no lo podía creer. Está bien, el señor dirá lo que dirá, la 
pasó muy mal, casi, casi, pero que el hombre se equivocó, da lugar y con los antecedentes que tiene, y dijo otras cositas... yo no lo podía creer.

Yo vengo de una orientación cristiana porque terminé en una escuela privada. Los del Terrero somos revisionistas en materia histórica y católicos. Entonces, obviamente que es una escuela laica pero también hay libertad de pensamiento y el eje ético se cimienta por lo menos, en los diez mandamientos. Entonces como un compromiso moral uno tiene que tener ciertos valores, claro, ahora están en boga. Primero habíamos sacado los valores, ahora cumpliendo con los valores para evitar la violencia.

E: -¿Qué herramientas se llevan a cabo en la institución frente a un hecho de violencia? ¿Qué se suele hacer en la escuela, frente a un golpe, un forcejeo, cuáles son las acciones que se suelen tomar?

P: -Muchas veces la escuela se ve superada. Nosotros tenemos la mañana con un grupo diferente que a la tarde. A la mañana tenés alumnos más predispuestos, más volcados a los conocimientos, no desfasados en edad, que vienen con la trayectoria escolar. Cuando uno repite ya no cumple con la trayectoria escolar, viste, primero, segundo. Esa sería la trayectoria escolar. Los de la tarde, por lo general, tienen menos notas, por lo general tienen mala conducta, tienen alta repitencia, viven en barrios muy aislados, los padres trabajan muchísimo. Recién vino una madre, se lleva a su hijo que repite segundo año, ¿qué le hizo? Como ya está desfasado, ya le vino repitiendo, le repitió primero, le repitió segundo, le digo: “¿pero no quiere dar las materias ahora en diciembre? Que dé las materias y apruebe segundo, vamos a ayudarlo que ya tiene diecisiete". ¿Qué dijo la señora? "Lo paso a adultos que me dijeron que el nivel es la mitad, que en tres años termina, saco la cuenta y le gano dos años al sistema”. Vos decís: ¡Opa! Cómo lo sabe la señora con escasos conocimientos de los planes educativos, mirá vos, cómo la mujer en cinco minutos resolvió un problema medianamente serio.

E: -¿Cree que los problemas vinculados con la violencia vienen de afuera o surgen de la institución escolar?

P: -Las carencias te predisponen mal, cuando vos estás en un ambiente que no es sano, que es un ambiente donde vos te sentís incómodo, es una forma de violencia. Yo no puedo 
querer una escuela semi destruida. Yo me caí porque un alumno hizo una broma. Yo quedé internado, me fracturé una de las vértebras, yo no puedo hacer juicio, todo el mundo le hace sumario a la directora, yo no puedo, estuve internado, quede fundido, entre los fierros, se me vino abajo un andamio. El tema es el siguiente. ¿Ves todos esos bancos que están ahí afuera? Una donación del poder judicial para que los chicos se sienten, para que estén en un lugar más cómodo. Conseguí cuatro butacas, otra me la pidió el chofer del camión que me hizo el favor y no podía cargar más. Me gustaría que los chicos estén cómodos, en un ambiente cálido, que se los reciba de otra forma; te predispones distinto si no tenés un ventilador, no tenés calefacción, los baños están destruidos y en el patio no hay lugar para sentarse. Están a la orden de Dios, no nos dan artículos para limpiar, dicen que ahora armaron una caja chica de mil pesos que para ellos es suficiente pero no nos dan bancos ni sillas. La escuela está toda rota, toda destruida. Vienen del Consejo Escolar, miran, toman mate y se van. Vos no te podés sentir cómodo. El ambiente también influye a ser una escuela que no está totalmente acendrada en lograr una relación armónica con las personas, no se sienten identificados.

E: ¿Entonces de alguna manera cree que el estado de la escuela colabora con el problema?

P: -Y sí, una escuela así, sí. Esta es una escuela que no tiene barandas para subir la escalera, no tiene para retener la contención que llevan las escaleras. Entonces no te sentís querido, no te sentís cuidado. Ya sé que los chicos rompieron la baranda, ya sé que los chicos quemaron la puerta y no tienen puerta para hacer popó. Bueno ahí les pusieron la puerta, tenés que ir a ver la puerta y lo que facturaron ¿Ahora qué va a pasar? El tema es del estado, el compromiso es de todos. Entonces, el portero que es un héroe de Malvinas, es muy observador y cuida, va a pintar. El pelirrojo, ex combatiente, va a pintar todo, vamos a dar con esmalte sintético, vamos a ver si cuando vengas el año que viene cambia la escuela y te recibe con colores, algún color, no importa qué color, pero un color, te ayuda, te calma. ¿Sí o no? Un color te puede relajar un poco, te motiva, te puede descansar la vista, te cambia, pero esta profesora que pintó esto está equivocada.

E: -¿Qué pintó la profesora? 
P: -No sé qué, pero mirá lo que hizo... Nosotros habíamos pintado el aula, ella no ayudó a mejorar y no me digas que es lindo eso, ensució todo, está mal. Otra profesora rompió libros y los colgó, todos libros agujereados. El mensaje: todos agujeros a los libros. Cuando vi eso... cerramos la puerta y apagamos la luz. Yo sé que lo que viene es la educación dos punto cero. Y a eso quería ir.

E: ¿¿Hay equipos de orientación escolar en la escuela? ¿Cómo intervienen esos equipos?

P: -Las intervenciones, dada la enorme complejidad que tiene el entramado social en la mira escolar, se abocan a los problemas judiciales, los más urgentes. Por ejemplo, por citarte un caso: una alumna tenía su papá, que tenía ochenta seis años y la alumna tiene catorce, quince. Una de las mejores alumnas que tenemos. Murió el hombre, los hijos la quieren echar de la casa, ella se atrincheró en la casa de su padre. Y le estamos dando cosas para que coma. ¿Qué navidad va a pasar esa piba? Ahora se puso de novia, una chica muy seria, la mejor alumna. Vive sola y atrincherada con el horror de que le quieren vender la casa y dar la parte, pero ella quiere vivir acá. Y está luchándola. ¿Y qué hacemos? ¿Quién interviene? No sé quién interviene. Hay una vecina que se hizo responsable de ella judicialmente, legalmente. Nada más, no estuvo el estado ahí para decir "pero acá hay un subsidio”. Para el preso sí, pero el preso le tiene que pagar a la víctima. Si le dan cuatro mil al presos, mil son para la víctima.

El trabajo del preso es muy sacrificado. Los locos en Romero van cargados con las ollas para todos, cargar y caminar veinticinco cuadras y limpiar todo. De un penal al otro, y a la noche también, y al desayuno.

E: ¿Qué aporte creés que sería interesante para el tratamiento del problema de la violencia?

P: -Uno no percibe que el lenguaje es una forma de violencia y que los códigos carcelarios están presentes en la escuela porque es el mismo idioma. Tenemos setenticinco palabras que ellos usan y que conforman un lenguaje común de grupo y obviamente que los grupos se van formando por inclinaciones naturales. A la mitad de un curso le cuesta expresarse, tienen un idioma pobre, dicen "una banda", "una banda" y de ahí no los sacás. Lo dijo el otro día Mujica, pero yo lo vengo diciendo antes que Mujica porque justamente empecé con 
el lenguaje de los tumberos y empecé con los tatuajes. Resulta que un amigo hacía prensa en la cárcel y me vinieron a ver del programa del "negro", que hizo Okupas en canal Once y que después hizo un programa de cárceles. Vinieron a ver mi libro de tatuajes. Ahí cada tatuaje tiene su explicación, los mejores tatuajes hechos por los presos; una pavada, pero es parte también de una cultura contestataria. Una ruptura del hombre. Si leés los cinco puntos, es: anti policía, anti institución, anti penitenciario, anti juez, anti gay. En el fondo es anarquista, pero es violento, es un mensaje violento. Ahí [señalando una pared del patio que se observa desde la ventana] podes ver los cinco puntos, ahí, a un costadito de la pared están los cinco puntos.

\section{E: -¿Además del lenguaje hay unos símbolos?}

P: -La escuela tiene que ser apolítica y educar para la paz. Por eso nosotros estamos atentos a todos los brotes posibles de violencia. Nosotros tenemos que escanear el humor del grupo y estar muy encima; desgraciadamente a mí me sirvió lo que aprendí en el sistema carcelario, porque les puedo preguntar: "vení Wily, decime, ¿qué pasó? Por ejemplo, la vez pasada, tiran una ametralladora, acá, y pensamos que era un tiroteo. Lo pensamos, sentimos pac, pac, pac y una explosión, no sabés, vino la policía y yo ya sabía quién había sido, al minuto. Fue propio de la cárcel, tener un informante, o llamalo como sea, pero es un informante, quién fue ya está, olvidate. Y es una forma de protegerlos a ellos, y ellos lo saben. Entré con la policía al aula, ¿y qué hice? Les dije: "ustedes saben que no es la mejor escuela, que no es la escuela que queremos"... Y yo lo miraba al que había sido. "Tengan el valor de parase y de decir quién fue". Después, con el tiempo hablé con él y nunca más. Él ya sabía, porque yo lo había mirado, entonces sirve. Yo le pregunto a los preceptores: “¿cómo vienen los muchachos? ¿Cómo vinieron los alumnos hoy?” Siempre hay pequeñas cosas, pero vos te das cuenta cuando están las amenazas, cuando están los golpes. Como nunca... una vez tuvimos tres peleas seguidas en el aula a las trompadas en las que se dieron bastante. No respetaron a la profesora; cuando me metí yo la ligué de costado. Lo peor que hay es meterse, pero hay preceptoras que están muy prácticas en las peleas. Me gustaría que hables con mi compañera. Ella tiene una cancha espectacular. Primero da trompadas y los empuja de atrás y de costado -y además esquiva- ¡vos tenés que ver! Por la experiencia que tiene es una peleadora ideal para contener situaciones de violencia que 
no pasan de las trompadas. Por suerte son solo problemas de liderazgo, son comunes, son frecuentes, en qué escuela no los hay, porque del golpecito al golpe hay nada.

E: -¿Qué piensa usted sobre el sistema de sanciones? ¿Cree que es efectivo, que no lo es, que habría que mejorarlo?

P: -Evidentemente, decía San Agustín, no se puede aprender en un contexto donde no existe el orden y, consecutivamente, se logra con el interés de los alumnos por lo que se está haciendo y por la preocupación y ocupación del docente y del establecimiento en brindar todas las herramientas motivadoras. Planes de estudios innovadores. Yo, por ejemplo, me he llevado a los míos al Observatorio Astronómico y han visto en pantallas tridimensionales unos viajes por Egipto, por Saturno y les he puesto el Google Earth para que sepan las coordenadas de su propia casa. Está en cada profesor despertar las ansias de conocer para dejar esa ansiedad que tienen los jóvenes de jugar de manos y pasar a los golpes en un cambio de humor. Ellos te piden las acciones disciplinares. Hay uno más grande de cuerpo que es líder y pega, y no pasa nada, hay que echarlo. Por ejemplo una alumna se peleó con una compañera y fue tan mala, tan mala -y eso que eran íntimas amigas-, cuestión que la empujó para que la pisara un auto, ¡la empujó en la calle de la escuela para que la matara un auto!

\section{E: - ¿Eso ocurrió en la puerta de este colegio?}

P: -Sí, sí, acá en la puerta. Si vos la ves a la chica, es una rubia, una modelo, no puede haber hecho eso, sin embargo tuvo toda la intención de quitarle la vida. Cuando la hicimos reflexionar se calmó, lloraba desconsoladamente. Me parece que se pelearon por un chico. En el fondo hay una gran lucha. Como era muy buena estudiante y estaba bien conceptuada por las máximas autoridades la ayudaron en el problema, porque en realidad habría que haberle aplicado una sanción. Las sanciones están en el acuerdo de convivencia y se saben cuáles son las faltas graves y las faltas leves. Y las sanciones están... suspender a un alumno de lo único que tiene que el estado que le va a brindar personalmente a él, es una sanción grave y es un atraso en su carrera. A veces los padres dicen "no hicieron nada", y el hecho de no ir al colegio lo descoloca, es un secundario obligatorio. Las faltas existen y están dentro del acuerdo de convivencia, lo que no está definido es la máxima, le falta, está incompleto. Está incompleto y forma parte del lenguaje de lo no dicho. Hay un lenguaje de 
lo no dicho que es violento, lo que no se dice, cuando un profesor actúa mal, cuando un preceptor actúa mal, cuando un alumno actúa mal. Por ejemplo, cuando un alumno va al baño y le pegan en la cabecita porque está fumando porro y no comparte, o porque no es del grupo, o porque no hace ese tipo de cosas, entonces, tuc. Ahora lo solucioné, yo lo solucioné. Le puse llave al baño y se acabó el porro. Vos tenés que ir solucionando, apagando incendios. Vienen de contextos muy humildes donde la violencia es el lenguaje cotidiano. Otra de las cosas: esta es una sociedad de consumo y, aunque a vos te parezca mentira, genera violencia. Yo tomé una coca cola y no quiero convidar, entonces todos los hechos de violencia es un tema a prestarle mucha atención. Porque el día que un alumno te pierda la vida se termina la educación. Yo quedo manchado para toda la vida, la escuela queda manchada para toda la vida y estamos así cada vez que se repite lo de Pantriste... yo lo tuve preso a Pantriste. En la cárcel le siguen diciendo Pantriste, y en la cárcel te queda. Ahora está arrepentido de no haber ido por homicidio ocho años y listo; lo pasaron por loco y es lo peor que le puede pasar porque no va a salir más. Hay otro que no, otro preso que hizo un desastre porque está en Ensenada, es una cárcel abierta, sale, estudia; en cambio este no pudo estudiar más, lo anuló la sociedad, lo quebró de todas las formas posibles, o sea, quebró al hombre y quebró al alumno, quebró todo por una situación de violencia que no pudo manejar. Por eso digo, hasta qué punto él es culpable. La escuela no lo protegió. Él es el máximo exponente de lo esperable en el desborde de una situación, él respondió. A Pantriste lo volvían loco dos chicos y él les tiró. A uno le pegó en la cabeza y al otro lo rozo. En cambio el otro chico, el de Carmen de Patagones, no se puede explicar, él fue contra los que le hacían bullying... el famoso bullying. ¿Nosotros tenemos problema de bullying? Claro que tenemos problema de bullying.

\section{E: -¿Qué entiende por bullying?}

P: -A todo y distinto tipo de violencia. La violencia del lenguaje verbal, psicológico, explícito, no explícito, desde lo corporal, lo físico, las diferencias, esas diferencias que asoman en una comunidad. Todos sociabilizamos en un espacio en que también hay diferencias, los chicos se encargan permanentemente de exacerbarlas, pero, justamente, está la tolerancia, está el aprender, por eso es muy rica la vida social. Un chico podrá ser estudioso o no. A vos te integra un grupo: ¿vos sabés lo que es trabajar en equipo? Cuando 
un profesor te dice, "bueno los seis, si uno sale mal, los seis salen mal”: ¿qué pasa? Vamos a explicarle, copia y lo llevan a la rastra. Está en las estrategias docentes no generar violencia, desde el discurso y desde lo formal también. A veces los gritos se escuchan, y un grito hoy pertenece a la violencia. Ese es un límite, por ejemplo, cuando hay un hecho de violencia ya se han roto varios diques, uno de los diques es levantar la voz. Cuando el profesor levantó la voz ya pasó a otro nivel. Tiene tantos niveles la violencia, cuando vos le gritaste a un alumno no se lo olvida jamás, es como si le hubieras pegado, es una forma de recibir un cachetazo. Un día, vino un alumno, que ahora se hizo como amigo y me dice "vos me gritaste un día y me pusiste mal"; "pero si estabas rompiendo una silla que cuesta y no tenemos"... Pero él no se olvidó. No se olvidó del grito, yo le falté el respeto y estuve mal, le cometí un hecho de violencia psicológica.

E: -¿Qué rol cree que juegan los medios de comunicación con los problemas de violencia? ¿Cree que colaboran en magnificar el problema o son indiferentes?

P: -La exposición genera más violencia; reproducir las malas noticias, ese es el punto. Los hechos de violencia son ¡la noticia! Cuando en realidad deberían ser las buenas. ¿Qué nos llega? Los programas culturales que nos educan para un mundo mejor del tercer milenio, para alcanzar metas que nosotros pensábamos que ya, para el tercer milenio, estaban resueltas. Todavía están sin resolver porque se sigue poniendo el acento en la violencia como un eje político. Entonces, justamente, a mí me toca todos los días, tomarme cinco minutos y referirme al hecho que nos ocupa hoy para contrarrestar toda esa carga negativa. Como la pila, tiene lo positivo y lo negativo. Todo lo mismo. Los medios nos ayudan, en gran parte, porque nos permiten tener una sociedad informada y entrenada, minuto a minuto, pero también conlleva que eso hay que trabajarlo, porque todos los hechos son violentos, las malas noticias son las que venden y se comercializan.

Entonces, para un mundo de consumo, vemos que alguien tiene un reloj, vos bajás la ventanilla para darle una moneda y él te arranca la cadenita de oro. Eso, hay que estar preparado para eso. Vos sacaste el celular y miraste para el otro lado y te robaron el celular, que justamente esta sociedad de consumo no la tuvimos antes. Esta sociedad tiene código de barras, el código de barras que casualmente tiene tres barritas que es el seis, seis, seis, parece que fuera la bestia del apocalipsis. Fíjate que el código de barras tiene tres patitas y 
esas tres patitas tiene: seis, seis, seis. Te quiero decir que el ultra comercio, el ultra capitalismo, no ayuda. La sociedad de consumo no ayuda. Hoy se nota el chico que tiene frente al que no tiene. Sacándonos los guardapolvos, liberándonos de ese gasto del guardapolvo, y poder mostrarnos en un mundo exhibicionista, hedonista. La escuela sacó los guardapolvos blancos que para nosotros eran identitarios. Justamente el guardapolvo desnuda ahora las diferencias sociales. La ropa de marca se ve, el alumno que viene con el pantalón destruido, y te digo del dos mil once al dos mil catorce vienen destruidos.

E: -¿Destruidos en qué sentido?

P: -Justamente el otro día vino un chico que se le había roto la zapatilla y justo teníamos una caja de zapatillas, así que le dimos zapatillas. El tipo contento con un par de zapatillas nuevas, te imaginas, le cambiamos la vida. Salió con una sonrisa. Si vos vieras la madre... y lo hicimos pasar de año. Un chico que salía pateando y golpeando a toda la escuela y gritando. Hay chicos que les cuesta horrores, frena la calidad educativa, vamos con contenidos mínimos, pero priorizamos el hombre y el ciudadano. Ese es el rol de la escuela y te digo que es vital, la tarea del docente es vital y es ética, entonces es fundamental el rol del profesor, y del preceptor ni te cuento. Todo se centra ahora en el código institucional, a mí me gustaría que vos lo revises y veas que hay puntos en el código institucional que se quedan sin respuesta frente a hechos de violencia, porque te quedas sin herramientas. La directora frente a la alumna no tenía herramientas ella. ¿Qué hacemos con esta alumna? ¿Qué hacemos con el docente, con este hombre? A ver, no es solo el problema de violencia del alumno, el problema es también el personal. El tema de las sanciones, y sobre todo la Dirección de Escuelas, a la escuela le faltan todas las herramientas y se genera violencia. ¿Por qué? Porque esta todo cerrado. Los padres se quieren comunicar pero la preceptora falta toda la semana, pero durante diez años. Nadie le hace un examen psicológico. Es el sistema. Empezando por el sistema... los profesores, los preceptores, todo el cuerpo educativo no está en condiciones. Tenemos las herramientas, después si bajamos a los chicos, pero sería lo último, acá hay que revisar la planta orgánica funcional si está en condiciones de educar a los alumnos. ¿Están organizadas las escuelas? Y saber quién está haciendo cada cosa, la POF y la POFA... Hay diez personas que no vienen, que huyen de los alumnos. 


\section{Entrevista grupal con tres miembros de un Equipo Distrital de Infancia y Adolescencia}

Nombres ficticios: Andrea, María y Débora

Duración: 51 minutos

E: -Cuéntenme su nombre, su especialidad y su experiencia en educación.

A: -Yo soy profesora y licenciada en Psicología y trabajo hace más o menos 25 años en el área de educación.

M: -Yo soy profesora en Ciencias de la Educación, hace 24 años trabajo en educación. Trabajé como maestra y en equipos de orientación.

D: -Soy profesora en Ciencias de la Educación y maestra de grado. Trabajé muchos años como maestra y en equipos de orientación. Soy Orientadora del Aprendizaje en este momento y tengo 32 años en educación.

E: -Sin importar el orden en que respondan: ¿qué significa para ustedes el concepto de violencia?

A: -Inherente al ser humano. Es parte de la humanidad, como parte de los vínculos que se establecen entre un sujeto humano y otro sujeto humano.

M: -Digamos que los conflictos son inherentes a la condición humana.

A: -Pueden darse situaciones de violencia o no...

M: -...Pero hay formas de solución y ahí está el punto de lo educativo. No hay que negarla [la violencia], sino hay que pensar cómo en educación se pueden resolver los conflictos.

D: -A mí me parece que es inherente y constitutiva del ser humano. En realidad los seres humanos tenemos como parte de nuestra constitución la cuestión de la violencia, entendida como aquello que uno aprende desde pequeño a reprimir y a reconducir. Y me parece que es allí donde aparece la educación. ¿Qué pasa con el límite que tenemos con el otro? ¿Y qué pasa con el propio límite si aprendemos esa cuestión? Ahí empieza el recorrido. 
E: -¿Ustedes creen que existen situaciones de violencia en contextos educativos secundarios?

A: -Ocurren en todo contexto y por lo tanto la escuela va a ser reflejo de lo que pase, porque si esto es parte, o tiene que ver con el conflicto como constitutivo, lo más probable es que en los vínculos humanos haya situaciones que tienen que ver con lo conflictivo pero también con pasar a la acción y que tengan que ver con actos violentos. Entonces, en ese sentido van a pasar en la escuela primaria, secundaria, en el jardín de infantes, en la vida, en la esquina, en el barrio. Lo más probable es que el ser humano tienda a aniquilar al otro si puede. La cultura pone algunas reglas de regulación a esta posibilidad afectiva que por constitución cada sujeto construye. Entonces la educación como parte de la cultura es quien marca unos límites fuertes. Nosotras lo que observamos es que pasa mucho más en la calle que en la escuela pero se observa más en la escuela que en la calle. Obviamente todos los sujetos están en la escuela, desde muy chiquitos hasta los dieciocho años; lo que pase en la vida cotidiana se va a reflejar en la escuela porque están vinculándose ahí durante catorce, quince años de su vida...

M: -...La escuela es el escenario donde están reunidos. Pero toda la experiencia que tenemos es que ocurre [los episodios violentos] en un momento, los lunes era un día donde aparecían situaciones que venían del fin de semana: "Que me mirás”, “que me agarró”, y la escuela explotaba.

A: -Yo creo que la escuela, como parte de la cultura regula mucho más posibilidad de los vínculos. Si bien aparece, está mucho más mediatizada que las situaciones que escuchamos que aparecen cotidianamente en la calle.

D: -Tiene que ver también con el contexto socio-histórico. En la época de los noventa era desesperantemente violento en cuanto al hambre con el que venían los chicos. Era pasar el fin de semana, donde no había posibilidades de alimentación, esperando que llegue el lunes para ir a comer a la escuela. Hoy no se ve tanto eso, hoy se ven quizás otras cuestiones. Me estaba acordando de una conferencia de Meirieu que me movilizó muchísimo y cuento cada vez que puedo a mis alumnas: en la posguerra había muchos judíos huérfanos y había gente que se encargaba de reunirlos para ver qué hacían con esos niños - no recuerdo ahora el nombre de quién lo contó-, el trato entre ellos era de una violencia extrema, resolvían todo 
a las patadas, a las piñas, con la intención de eliminar al otro literalmente. Entonces, se le ocurrió una especie de caja para poner allí los conflictos. Les iba a permitir una pelea posterior, pero ellos tenían que poner por escrito el motivo y lo que querían hacer con el otro. Tenía que mediar esa palabra, y el que no podía escribirlo porque no sabía, podía decirlo y otro escribirlo. Él iba a permitir hasta la eliminación del otro. Esa mediatización con la caja lo que permitía era distanciar la posibilidad de la pulsión inmediata; si bien no se resolvía totalmente, al mediar la palabra y la posibilidad de ponerlo en otro lugar, él contaba que esto de alguna manera permitía otro paso. Ese límite permitía interactuar con el otro desde otro lugar. De algún modo es lo que intenta hacer la escuela, poner en palabras aquellas cuestiones.

A: -Esa sensación de que ahora [la violencia] aparece más en la escuela secundaria, debe tener que ver con que no estaban todos en la escuela secundaria hace un tiempo y ahora hay muchas más posibilidades de situarse desde el vínculo con un montón de sujetos que son diferentes. Antes no es que podían anotarse en la escuela; si se anotaban en la escuela, a la primera situación que aparecía, la escuela tenía reglas de expulsión libres. Podían no ir a la escuela, como no era obligatorio y era de elite, aquellos que no estaban dentro de los parámetros que la escuela esperaba, rápidamente se lo excluía y no seguía estudiando en la escuela secundaria. En la escuela se deben regular las situaciones de vínculo, se tienen que dirimir ahí las situaciones conflictivas, no por fuera de la escuela. Es como el ámbito por excelencia para poder dirimirlas. Entonces, esto tal vez colabora en que los medios de comunicación construyen fuertemente en nosotros la sensación de que esto es mucho peor ahora de lo que era antes. En realidad, en el antes pasaba algo y los chicos rápidamente quedaban afuera. Entonces desde el sujeto no se posibilitaba un trabajo educativo pero a nadie le importaba porque no era obligatorio.

M: -Yo creo, por intervenciones que hemos tenido, que los chicos saben que en la escuela no, entonces se agarran en la esquina. Por eso estas cuestiones ocurren cuando salen de la escuela. La escuela es un lugar de contención donde tienen un nombre, donde se genera algún vínculo con alguien. Es como si se cuidaran y en la escuela no, pero en la esquina, a la vuelta... lo que se produce en la calle no se produce adentro de la escuela... 
D: -...Dentro de la escuela son mucho más excepcionales, las podemos contar con los dedos de las manos y podemos acordarnos de ellas porque los medios de comunicación las hacen resonar mucho, demasiado. Igual tampoco son tantas las situaciones que suceden afuera. En muchas de las situaciones que suceden afuera, algunos de los chicos que mencionan los medios como agresor o agredido -estamos hablando de chicos de quince o dieciséis años-, muchas veces el que agrede no está escolarizado en ese momento. En la mayor parte de las intervenciones es algo que se puede establecer: el que agrede fuertemente, y hasta mata al otro, es un niño o un joven de dieciséis años que no está escolarizado en ese momento. Alguna vez lo estuvo pero hace un año y medio o dos años que no va a la escuela, y no es un dato menor esto.

M: -Lo que escapa al adulto es la conexión que ellos hacen a través de las redes sociales. Estas provocaciones, estas susceptibilidades que se generan y después se completan.

A: - [Interrumpiendo] Ahí el adulto siempre funciona como regulador. Entonces, en las redes sociales, lejos del amparo del adulto, la regulación no va a estar. Es prioritario que la escuela trabaje a partir de las redes sociales, es fundamental. No podemos decir que la escuela no se tiene que meter con las redes sociales, la escuela tiene que ser parte de la trama educativa. Porque los chicos hoy están todos ahí produciendo sentidos, hay que educar en esos formatos nuevos también.

M: -Además cuando indagamos lo que les pasa a los docentes, o analizamos el motivo de semejante violencia, semejante pelea, arrancan con "me miró". Es un "me miró" que no lo pueden describir, es una cuestión de piel. La mirada justifica "te reviento, te saco la mandíbula". Cuando uno quiere desandar cuál fue la causa... y lo he corroborado con todos los chicos con los que tengo contacto.

A: -También hay cuestiones de género junto con la mirada, "miró a mi novia" o "mi novia salió con vos también". No se le permite a la mujer tener multiplicidad de relaciones, sí al varón. Si en el trayecto de una relación, la chica sale con otro, esto no es sostenido igualmente como es sostenido para los varones y entonces se pelean los varones hasta llegar a matar al otro. 
M: -El odio entre mujeres también es bastante frecuente, por ejemplo "se hace la linda". A veces también el novio interviene y la mata a la otra. Esta cosa de posesión es muy primitiva, es como un objeto.

D: -Cosificar al otro es algo muy elemental... hay que ver si el chico está escolarizado o no...

A: -...En muchos de los casos en que participamos más activamente pudimos observar que el que mata no está escolarizado. La única relación que tiene con la escuela es que lo va a buscar a la puerta porque sabe que ahí lo va a encontrar.

D: -Cuando decimos que "no está escolarizado" es porque no es posible que medie la palabra en ningún momento, es otro tipo de representación, eso es grave. No hay un lugar común como lo es la escuela...

A: -... Ahí la escuela no estuvo para trabajar los vínculos, o trabajar el género, o profundizar un poco los sentidos y la mirada. Entonces es muy difícil que esa situación se pueda anticipar plenamente. Cuando los chicos están todos en la escuela, es posible la anticipación, uno puede trabajar en lo previo. Seguramente que la escuela colabora muchísimo más de lo que muestran los medios para anticipar que esto no suceda. Como todavía sucede excepcionalmente, no sucede todo el tiempo -todo el tiempo suceden otras cosas pero no estas-, ahí funciona esta herramienta de regulación que tiene la función educativa, que es una dimensión netamente humana. Si el conflicto es inherente al ser humano, la educación es el antídoto para poder regular los vínculos; y lo produce en grandes masas porque lo produce en Argentina como estado.

M: -Nos encontramos en un contexto general de crisis de las instituciones. Hay crisis en cuanto a las reglas que tenemos como sociedad. Traspasarlas todo el tiempo, ir y venir, creo que es parte de estos tiempos. Hasta que encontremos un nuevo acuerdo social que nos regule... la posición del adulto se corre, sobre todo en el jardín: "no le voy a decir que no" “cómo le voy a negar tal cosa al chico", ese chico es un "niño rey”. Se deja librado al niño, en tiempo de la infancia no hay regulaciones. El adulto se corre, las reglas sociales se pasan todo el tiempo, estamos en un tiempo un poco complejo. Los límites te marcan y al mismo tiempo permiten el día de mañana revelarte también. Tiene que haber ciertos acuerdos y me 
parece que ahí hay un corrimiento del adulto que está en crisis. Como sociedad se producen determinados hechos no sancionados...

D: -... A veces esos adultos se están constituyendo en la escuela secundaria. A veces son mamá o papás muy jovencitos. A veces cuesta por eso regular el propio límite y regular el límite de su hijo. Son nuevas conformaciones juveniles, es tiempo de cambios. La escuela por ahí también tiene que ir revisando estas cuestiones. Lo que propone y normativiza la escuela secundaria son los centros de estudiantes, que son un buen lugar para poder construir esto que nosotros llamamos democracia. Puedo discutir con el otro y lograr intercambiar ideas no necesariamente comunes, vamos cada uno con su idea; ese ámbito no estaba pensado antes.

A: -La posición de los adultos en la escuela está atravesada por sus propias lógicas escolares que son distintas a la de sus alumnos. Una persona más grande que es profesor de secundaria no entiende cómo se pueden regular los vínculos sin sancionar ni excluir de la escuela al otro. Piensan la autoridad desde una regla fuerte que establecía la posición que ellos tenían. La autoridad tenía que ver más con la cuestión del poder, no era una cuestión menor quedarse sin escolaridad. Hoy la ley dice que todos tienen que estar escolarizados, entonces te encontrás con profesores que quieren posicionarse desde reglas que ya no son parte de un sistema democrático. Nos va a llevar mucho tiempo transitar la democracia desde la escuela. Hay directores que tensionan con la idea de tener un centro de estudiantes y tratarían de no conformarlo. El acuerdo de convivencia, por ejemplo, requiere representantes de curso, y cuando les preguntamos dónde están nos responden "todavía no están", "recién empezamos", y eso no ayuda.

M: -Cuando se construyen los acuerdos de convivencia deben ser reglas acordadas, y esto es parte de la construcción de la ciudadanía...

A: -...Es nuevo esto, empiezan en el año 2007 y estamos en proceso de armado donde participan menos los jóvenes y más el adulto. Entonces son reglas bastante parecidas a las que el adulto tenía en la escuela secundaria.

M: -Los chicos son más duros a la hora de pensar las reglas, ellos dicen “¡no!” Hay que escucharlos, fijate que son estrictos, es más que interesante. 
E: - ¿Podría hablarse de una demanda de los chicos por la autoridad del adulto?

M: -Ellos demandan que se pongan reglas y que se cumplan, que se hagan.

D: -Cuando se plantean situaciones, el adulto es muy difícil de encontrar. Cuando pasa algo en la escuela, lo primero que nosotros preguntamos es: ¿dónde estaba el preceptor? En general los chicos estaban en una situación donde empezaban a tensionar y fue muy difícil ahí que alguien piense de otro modo. Por otro lado a veces tensionan con el adulto, porque el adulto está en una posición totalmente individual, no tiene posibilidad de pensar al otro como un joven en formación. Entonces a veces empieza una escalada de violencia entre el adulto y el joven que por lo general no termina bien. Porque alguno de los dos hace uso de la acción.

M: -La autoridad se construye, el hecho de que yo tenga un cargo no me da la autoridad; según los chicos, es alguien que les genera confianza, que los escucha, alguien que cumple su palabra, alguien que está. Nosotros trabajamos mucho la cuestión del referente para el grupo, alguien que esté cerca y que para ellos sea importante, hoy la autoridad se construye desde ahí. A los chicos la autoridad del director no les importa, quizás viene esa persona y logra que los chicos escuchen, puedan cambiar, generar otra cosa.

E: ¿¿Qué opinan sobre el actual sistema de sanciones basadas en advertencias y elaboración de actas?

A: -Ahora lo que hay es un acuerdo de convivencia, ahí está pautado eso que vos decís de las actas. Son cosas, en algunos casos sí, en otros no necesariamente. Lo que sí está pautado ahí son cuestiones que no están contenidas en la normativa. Es decir, todas aquellas situaciones cotidianas, de vínculo, que pueden no estar acordes a lo que la escuela está pensando. Ahí hay un conjunto de reglas que todos acuerdan, que están construidas por todos.

M: -Si las reglas están construidas por todos, si todos conocen el reglamento: un acta, un consejo de convivencia, reuniones...

A: -Todos tienen que tener medidas reparatorias, porque en realidad no se sanciona definitivamente al sujeto por alguna cuestión, sino que se busca pensar en algunos espacios de palabra y de reflexión, y luego, intentar una medida de reparación. Que puede ser -si es 
sencilla la situación- desde pedir disculpas hasta otro tipo de reparación, que de alguna manera permita reposicionar la situación y pensarla desde otro lugar. Eso sí tiene que estar en un acuerdo de convivencia, después si va o no un acta, cada cual lo va pensando de un modo particular.

E: -Quisiera compartir una experiencia: en una escuela secundaria, en un grupo de segundo con 38 alumnos con el que me tocó trabajar el año pasado en Construcción de la Ciudadanía, ocurrió que no pude dictar una sola clase de acuerdo a la planificación previa; en cambio eran recurrentes las interrupciones y los pedidos de silencio. Es entonces que me acerco a hablar con el director para comentarle lo que me sucedía y convocar una reunión con directivos, preceptores, docentes, para, justamente, buscar una solución entre todos. Para esto yo ya sabía que le ocurría lo mismo a otros colegas con el mismo curso. La respuesta del director fue "hace un acta”.

A: -Esos chicos no quieren escuchar, entonces quizás habría que empezar la clase al revés. Que ellos empiecen hablando de un tema o un eje, entonces cambiamos la dinámica absoluta. Yo no voy a dar una clase, sino que voy a construir una clase en función de lo que los alumnos me vayan diciendo. Porque evidentemente si los chicos tienen tanta necesidad de hablar, tienen que ser escuchados, entonces lo que hay que hacer es parar como uno pensó la clase, barajar y repensar. Yo creo que ahí tiene que haber una actividad muy fuerte, sobre todo con 38, no son chicos pasivos. Entonces, a ver, ¿cuál sería el ejemplo contrario? Que yo tenga 38 sentados y que todos me dejen dar la clase, entonces ahí me tendría que preocupar cinco veces más que la otra posibilidad. Porque entonces, ¿cómo hago para qué me cuenten lo que les pasa por lo cual están tan atentos los jóvenes a los señalamientos del adulto? Esto me parece extraño y puede provocar cuestiones más importantes; en cambio con el otro sentido, el hecho de hablar y ser activo en eso, seguramente habilita de otro modo la posibilidad de que el sujeto transite espacios sociales. Entonces me preocuparía mucho más en las otras ocasiones. La palabra "dar", "dar clases", yo tengo que dar al otro... y por ahí el otro está en ese momento necesitando otra cosa ¿Por qué? Porque toca una tecla y encuentra lo que estás dando en una computadora. No va a escuchar porque no hay ningún problema, ninguna pregunta. No hay necesidad de conocimiento, porque ya lo sabe. Mucho tiene que ver con esto, nosotros queremos dar una 
clase de contenidos y los chicos lo pueden encontrar en cualquier lado. Para producir conocimiento tiene que haber alguna pregunta, entonces por ahí habría que escuchar cuáles son las preguntas que ellos tienen.

D: -A veces el contenido puede ser la escucha. Nosotras pensamos siempre las cuestiones anticipatorias de la acción. A veces el contenido puede ser la excusa de preguntarse: ¿qué les está pasando? ¿Qué sucede que no pueden escuchar al otro? Capaz que tampoco se pueden escuchar entre ellos, entonces ahí hay algo más que interesante para trabajar.

M: -A mí me parece que algo que no estamos diciendo es la violencia que se ejerce hacia los jóvenes. Estamos hablando como si los jóvenes fuesen los únicos que tienen manifestaciones de violencia y la verdad que las instituciones en su formato, y los adultos en particular, provocan y realmente tienen actitudes violentas hacia los jóvenes y hoy los jóvenes tienen una posición mucho más fuerte. Antes la posición era de acatamiento, con toda la bronca del mundo, pero ahora el chico se para y le contesta que no, y no, y no y no.

A: -Cuando hay situaciones de jóvenes y adultos son muy tensionantes y no terminan bien del lado del adulto y del lado de los jóvenes. Cuando hay situaciones con adultos, en general el adulto tuvo que ver muchísimo. En muchos casos fue la posición del adulto la que desencadenó una situación. Entonces ahí en vez de señalar al joven tendría que ser al revés. Hay que repensar la posición que tiene el adulto con respecto al joven.

M: -Allí se genera una espiral de violencia. Hay que preguntarse, ¿de dónde viene esto? Y creo que a veces las condiciones socio-económicas son violentas. En general se piensa que los portadores de la violencia son los jóvenes y en realidad la provocación existe cuando las expectativas de la cotidianeidad no están cubiertas, ahí estamos hablando de otras violencias. Creo que los jóvenes no son violentos sino que hay que pensar desde lo sociológico y en cómo el sistema te provoca.

D: -Hay que pensar cómo están los vínculos hoy y el lugar que tiene cada uno.

E: -¿Qué rol creen que juegan los medios de comunicación en relación al tema de la violencia en las escuelas?

M: -Un ejemplo en una intervención que tuvimos que fue extrema: sucedió en un micro y los medios necesitaban relacionarlo con una escuela... 
A: -...De las personas involucradas solo una estaba en edad escolar. Ahí lo más loco era que hablaban de "bullying en el micro", y el concepto de bullying les permitía establecer que esto era sostenido de manera sistemática, porque el bullying, justamente, es una situación de hostigamiento que tiene que tener las características de sostenimiento y de sistematicidad. ¿Dónde los vínculos pueden ser sistemáticos y no ocasionales? En la escuela. Entonces todo el mundo va a construir la idea de que esto es una situación de violencia en el interior de la escuela. Rápidamente terminó siendo una "violencia escolar". Es un artificio que si uno no lo deconstruye, y es muy difícil que la señora que prende la tele lo pueda deconstruir, eso entra rápidamente a su casa y a su vida. Cuando alguno de los involucrados en un hecho de violencia no va a la escuela, cuando el que mató no va a la escuela, eso no es reflejado. Lo que es reflejado es que fue en tal escuela. No solamente que haya sido fuera de la escuela, porque la mayor parte de los casos ocurrieron fuera de la escuela. Hubo uno o dos hechos que podamos recordar que ocurrieron dentro de la escuela. En la provincia de Buenos Aires hubo solo dos hechos en los que murió un alumno dentro de la escuela. Todos los casos ocurrieron fuera de la escuela, y, en una situación, uno de los involucrados no estaba yendo sistemáticamente a la escuela desde hacía un año y medio. Sin embargo, los medios dicen: "violencia escolar".

D: -Construyen un discurso y un posicionamiento político, porque recuerdo el caso de la profesora a la que le prenden fuego el pelo y lo repetían cotidianamente, todo el día, durante no sé cuánto tiempo. Es una manipulación política ideológicamente posicionada. El común de las personas dice "esto sucede todo el tiempo en la escuela", y en realidad fue un hecho. Esto tiene que ver con el momento, es decir, cuando los medios quieren poner algo en la agenda. Los medios como herramientas de los poderes políticos...

A: -... Casi desarrollan como una contra-educación, porque ellos saben que en educación hay un poder importantísimo, entonces, al desprestigiar la educación, ellos tienen un lugar prioritario. Rápidamente se quiere deslegitimar el lugar de la escuela. En realidad la escuela sigue sosteniéndose, y la verdad que es la mejor forma de educar.

M: -Cuando los jóvenes utilizan la tecnología, son ellos los que suben material para mostrar situaciones de autoritarismo en general. Uno ve cosas tremendas... y es como la forma de escrache o la forma de ser escuchados... 
D: -...Allí están los jóvenes queriendo decir lo que por ahí no pueden decir en otros lados. M: -Nada de esto es todos los días, ese es el problema. La repetición y la existencia de una intencionalidad lo instalan como problema.

D: -En las imágenes pareciera que el adulto no está, porque están solo ellos. Salvo en imágenes dónde están involucrados profesores golpeados. Les gusta mostrar que en el aula no hay existencia del adulto, no hay existencia pedagógica porque no están dando clases. Es algo anterior, como sujeto humano no tiene existencia porque no tienen ninguna posición, son cosas. Ellos [los medios] necesitan mostrarle a otros, que también son adultos y van a mirar eso, lo que está pasando con la posición del adulto. Si nos dejamos llevar por las imágenes seleccionadas es muy apresurado decir que a los chicos no les interesa otra cosa más que pelearse.

M: -Eso de subir a la web, meterse y provocar una pelea, para mí es una pregunta: ¿no es un juego? Estoy hablando de situaciones por fuera de la escuela. Esto de "dale, dale que se van a matar", "vamos todos juntos"...

A: -...Ellos muestran todo, no muestran solo lo que pasa en la escuela, lo que pasa que después rescatamos eso. Muestran todo, todo el tiempo; escenas más de lo privado, más de lo público. La imagen tiene un lugar prioritario, ahora, primero puede ser el Facebook, después el Instagram y los adultos ahora usan esas redes. Entonces, ¿qué les queda a ellos para mostrarse como espacio de condición juvenil? Entonces va a ser cada vez más espectacular la forma de mostrar: ¿cómo hacen para mostrar lo intra-generacional si terminamos todos en la misma generación? ¿Si nos encontramos todos en Instagram? Necesitamos, para poder establecer una diferencia, un espacio. Si busco lo mismo que los chicos, entonces los chicos van a buscar otros espacios más espectaculares para mostrarlo donde tal vez ahí nosotros no nos mostremos, no de esa manera.

E: ¿¿Qué aportes creen que serían interesantes para trabajar con el problema de la violencia en la escuela?

M: -Pensarlo en términos de la palabra...

A: -...Igual no creemos que los jóvenes y la violencia van de la mano. Lo que sí tenemos es que como los chicos están en una situación de ser atravesados por la dimensión educativa, 
es decir, que están en formación. El adulto está en la escuela y el profesor tiene un lugar prioritario, porque están construyendo su mundo, su vida, pero no porque los jóvenes y la violencia estén de la mano. Todo lo contrario, hay más adultos violentos que jóvenes en situación de violencia. Entonces, si uno hace un racconto de los medios de comunicación, hay mayor cantidad de situaciones de muerte en adultos que en jóvenes. Uno escucha "la escuela está cada vez peor", y en realidad nosotros pensamos que es al revés. Los chicos van a estar atravesados por cuestiones simbólicas que nosotros no tuvimos, en nuestras épocas no había centros de estudiantes, no teníamos espacios de exposición ni espacios de voz, no podíamos decir lo que nosotros pensábamos. Hoy todos los sujetos tienen ese lugar prioritario, y eso también supone mayor ejercicio de la democracia, que todavía no lo tenemos. 


\section{Entrevista grupal con dos integrantes de un Equipo de Orientación Escolar pertenecientes a la "escuela de la periferia norte"}

Nombres ficticios: Marianela y Gabriela

Duración: 26 minutos

E: -¿Arrancamos por el nombre y la función?

M: -Soy orientadora social. Trabajadora social en verdad.

G: -Soy psicóloga y profesora en psicopedagogía.

E: -¿Cuánto hace que trabajan en establecimientos educativos públicos?

M: -Yo 14 años.

G: -No, yo menos. ¿Pero qué podrán ser? ¿Estamos juntas nosotras cuánto hace?

M: -Y, hará 5, 6 años.

G: -Puede ser, ¿no? 5 o 6.

M: -En realidad yo inicié mi carrera digamos en la docencia como maestra jardinera, hace 4 o 5 años que estoy trabajando en Equipo de Orientación Escolar.

E: -Y acá en la escuela la función sería la de equipo...

G: -Equipo de Orientación Escolar.

E: ¿¿Dependen de la Provincia de Buenos Aires?

M: -Dirección General de Cultura y Educación, y somos de la modalidad de psicología. Si bien trabajamos dentro de una institución escolar, dependemos de una inspectora, en este caso la inspectora de psicología, y venimos a trabajar las problemáticas que se presentan en la escuela.

E: -¿Y en esta escuela qué problemáticas suelen aparecer?

G: -Y acá problemas de lo que comúnmente se llama problemas de conducta. En el anexo, en este. La escuela secundaria sabés que tiene una sede y dos anexos... es complejo, y para nosotras que alternamos, tenemos que cubrir todos los turnos y en las dos instituciones. 
E: -¿Y han tenido hechos de violencia acá en la escuela?

M: -Sí... ¿Cuando vos decís violencia a qué te referís?

E: - ¿Ustedes qué entienden por violencia? Les cambio la pregunta, en vez de responderles yo les repregunto.

G: -Nuestra modalidad eh... nuestra modalidad se llama psicología comunitaria y pedagogía social. Para la modalidad la define digamos en sentido estricto y en sentido amplio, ¿no? En sentido amplio se ven, se ven varias situaciones de violencia.

\section{E: -En sentido amplio entonces...}

G: -En sentido amplio. En sentido estricto por ahí no es tan... tan común. En sentido estricto, por ejemplo, la violencia podría ser aquellas situaciones donde uno termina con alguna lesión, las situaciones de robo, uso de armas, extorsiones, eso sería como violencia en sentido estricto, la palabra, por ejemplo. Ya en sentido más amplio podría ser eh... insultos, agresiones, las estigmatizaciones que se dan mucho también en las escuelas. Y bueno, este último sentido se ve con bastante frecuencia.

M: -También por ahí por la corta experiencia que tenemos acá en esta escuela se puede observar que muchos profes, no sé, manifiestan, se siente violencia dentro del aula. Digamos... "la directora me faltó el respeto, me insultó, me agredió", pero cuando vos empezás a indagar un poquitito más allá del hecho puntual que el profesor declara, te das cuenta que también hay una violencia de parte del profe. Esa es la violencia que generalmente está instalada. Esto está instalado en las instituciones educativas, donde se naturaliza y muchas veces se pone el punto o la mirada en el alumno.

G: -En la Argentina está esto de que el violento es el alumno.

M: -Exacto.

E: -La idea de que el alumno es el violento... ¿es relativamente nueva no?

M: -Antes el alumno era pasivo, digamos, no tenía la posibilidad de expresar lo que sentía y si tenía algún problema personal lo dejaba afuera. Porque adentro de la escuela no podía suceder ningún tipo de transgresión. Entonces hoy por hoy vos podés hablar con un 
profesor o mismo con cualquier integrante de la institución y te va a decir que el violento es el alumno, el problema es el alumno. Nunca hacemos una mirada desde lo personal. Porque la realidad es que la violencia está instalada en la escuela pero es una violencia social que por supuesto traspasa las paredes de la escuela y que se nos presenta.

G: -Es reflejo por ahí muchas veces de los conceptos violentos en los que están insertas las escuelas. No es que sea de la violencia escolar.

M: -Lo ves en el club, lo ves en un boliche cuando los chicos salen, no es una situación exclusiva de la escuela. Si vos observás un poquitito en los medios de comunicación cómo hablan de las escuelas, es como que responsabilizan en algún punto a los jóvenes... estos jóvenes vienen a desordenar la institución escolar.

G: -Desde nuestra modalidad es como que uno intenta contextualizar. A ver en qué red o relación se dio esa situación de violencia. Cuál fue esa red de relaciones que la generó y le dio sentido. Para correr esto, la mirada, de que sea el chico el violento y que el adulto, si es que hay algún adulto ahí en la situación (porque a veces se puede dar entre los dos jóvenes, dos alumnos ¿no?). Pero... porque si no, si hay un adulto y hay un alumno generalmente el violento termina siendo el alumno y el adulto queda como por fuera de la situación. Entonces en esta modalidad lo que se intenta es buscar esa red de relaciones en la que se generó y que se dio sentido. Involucrar también, si hay adultos ahí en esa situación involucrarlos también y bueno, poder pensar esa trama, cómo se fue dando y qué dio lugar para que tal reaccione de tal manera, qué se dijo antes.

E: -Cuando pensamos por ejemplo la violencia desde el docente hacia el alumno: ¿cómo suele manifestarse ese tipo de violencia?

G: -Sin dar nombres, acá nos ha pasado particularmente que por ahí los chicos se quejan en el modo en que se dirigen hacia ellos algunos preceptores por ejemplo. Marcan la diferencia, por qué tal sí y tal no, y ellos lo sienten así, sienten eso como una violencia. Y eso es un poco lo que desde la modalidad se habla de violencia en sentido amplio, ¿no? Esas situaciones que son vividas como violentas para uno, para el que está ahí en esa situación. Y esto nos ha pasado acá. 
M: -Yo sin ir más lejos hice un acta donde, por lo menos lo que describe el profesor de una situación es que el profesor estaba dictando clases, algunos alumnos estaban hablando, él creo que dejó, estaba esperando el tema nuevo, ¿no? Algo así, el profesor no sé qué le llama la atención... dice: “¿qué estaban hablando?” Entonces una alumna se enoja y aparentemente insulta al profesor, él la echa, la saca del aula y la manda a hablar con alguien del equipo directivo.

G: -Claro, el profesor por lo que decía el acta no le preguntó qué le estaba pasando. Si lo habían estado escuchando, digamos, como para que el otro se sienta en falta de que no lo estaba escuchando, porque si estaban hablando entre sí no los estaba escuchando. Pero en lugar de preguntarles qué les estaba pasando, qué estaban hablando, “a ver qué dije?”

M: -La realidad es que a veces en este lugar el profesor se pone de autoridad, en una relación asimétrica... "porque soy el docente vos me tenés que escuchar". Se genera... una especie de maltrato. Yo lo entiendo así, si yo te estoy dando clases a vos y yo te pregunto, “¿me escuchaste?” y vos me decís que no, y entonces yo te reto porque no me escuchaste y no te pregunté por qué no me escuchaste y demás, y sumado a eso te digo que te vayas de acá, que te vayas a dirección a hablarlo con la directora o con la vice directora, es también un poco en principio correrse de su lugar de autoridad. Deberías poder resolver esa situación, poder hablarlo, poder hacer que ese conflicto o hecho de violencia pueda ser metabolizado en algo positivo porque la realidad es que sucede... ¿qué aprendemos de esto? Y por ahí esos espacios en donde el alumno puede, poner en palabras no se lo das.

G: -Cuando vos los escuchas lo viven como una situación de violencia. Cuando a ellos les pasa algo y el profesor quiere continuar con la clase en lugar de parar y decir "bueno a ver chicos qué les pasa", y por el contrario los saca y les dice "van para dirección", ellos lo ven como una situación de violencia. Y te lo dicen. Y ahí es donde se desencadena toda la situación.

M: -Eso termina en un insulto, en un grito o no sé, que se enoje, que revolee algo. No estamos diciendo que esté bien, digo: tenemos que tratar de entender que esto que está instalado, ¿qué hacemos? Porque si vamos a seguir con la mirada de "bueno a ver, te portaste mal no me escuchaste, te vas, te amonesto, te echo de la escuela", no estamos resolviendo el problema. 
E: -También quería hablar sobre el plan de sanciones: ¿ustedes creen que las amonestaciones, las actas que están vigentes brindan soluciones eficientes?

G: -Sí, el acta a veces sirve y a veces no. Las amonestaciones nosotras particularmente creemos que no. La verdad que no, para nosotros no pasa por ahí, para nosotros es importante que los Acuerdos Institucionales de Convivencia funcionen, supuestamente acá ya hay acuerdos pero... creo que se hicieron hace dos años atrás ¿no?

M: -Sí, fue el año pasado cuando vino el nuevo director.

G: -¡Ah! Tienen vigencia. Bueno el tema que cuando le preguntamos a los chicos no tenían idea de los acuerdos, cuáles eran. Así que empezamos a trabajar sobre los acuerdos institucionales y... que eso nos parece importante a nosotros para evitar estas situaciones. Y después...

M: -Después digamos un paso siguiente serían los Consejos Institucionales de Convivencia, donde se abordarían aquellas situaciones que transgreden estos acuerdos. Tiene un equipo directivo y bueno, ahí se trata de ver cómo se resuelve ese problema.

E: -¿Los consejos están funcionando ahora?

G: -Debieran estar. Pero a nosotros hasta ahora no les hemos visto funcionar.

E: - ¿Ustedes creen que se debería darle más importancia a los consejos?

G: -Nosotros creemos que se debe trabajar así en situaciones de violencia. Creemos que debe ser así, desde la modalidad se cree que debe ser así abordada. Y que en las escuelas secundarias se pone mucho énfasis a la concepción de estos espacios colectivos de democratización para trabajar la situación. Como que esto permite, les permite a ellos regularse, regular su conducta, su modo de actuar.

M: -Yo creo que son parte, ahí está la importancia de estos acuerdos disciplinares y de poder trabajarlos con diferentes grupos porque ellos terminan siendo parte.

G: -Se los termina apropiando, que no es algo bajado... es más el sistema este disciplinario de...

M: -Sí, de sanciones, de lo que se puede y no se puede hacer dentro de la escuela. 
G: -Y lo ideal de los acuerdos es que participen también las familias y toda la comunidad educativa. Por ahí eso es lo más difícil. Pero bueno, deberían ser trabajados así.

E: -Me gustaría volver sobre el término violencia: ¿ustedes pueden distinguir diversos tipos? Porque como hablamos hoy, no es lo mismo una piña que un insulto. Sin embargo las dos acciones están incluidas dentro de la palabra violencia. ¿Ustedes qué creen?

G: -Sí, de hecho hay una autora que habla de violencias con S, en plural no en singular, porque dice que por las múltiples manifestaciones en ese sentido se amplió. Y sí, nosotros creemos que es así.

E: -También hay varios autores que afirman que el asunto de la violencia no tiene nada que ver con la pobreza. ¿Ustedes qué piensan?

G: -Y sí, no, no es así.

M: -Generalmente, claro.

E: -Las violencias pueden darse en cualquier institución educativa...

M: -Tiene más que ver con las relaciones vinculares; con cómo se entraman las relaciones con la historia de cada sujeto. Y también con la capacidad de aprender a contener nuestros impulsos.

G: -Claro, el psicoanálisis era esto que no es puesto en palabras. Lo no dicho, lo no pensado, lo no nombrado como que irrumpe en actos, dice el psicoanálisis ¿no? Entonces esto puede pasar en cualquier concepto, hay familias donde las cosas no se hablan, no importa que sea...

E: -Clase media, clase baja...

G: -Claro. Esto pasa, Ahí donde falta la palabra irrumpe el acto, irrumpe la violencia sin sentido. Y ahí es donde -desde nuestra modalidad- decimos que es importante que haya otro que medie eso. Que pueda codificar, traducir, ponerle palabras a esto que le pasa al chico. Y eso se puede dar en cualquier contexto, no está relacionado con la pobreza.

E: -¿Qué aporte creen que sería interesante para el tratamiento del problema de la violencia? 
G: -Yo particularmente creo que si cada docente leyera las comunicaciones que hay... está todo, en comunicación está todo escrito. En la modalidad de Psicología podés bajar todos los documentos que hablan sobre estos temas. Y me parece que ya al leerlos es como que te va cambiando la cabeza, la mirada que tenés respecto del tema. Pero a mí me parece particularmente que a muchas personas les falta lectura de eso. Sobre todo lo que está publicado en la modalidad de psicología. Que hay, está todo dicho, todo escrito.

M: -La realidad es que bueno, la capacitación en cuanto a la formación que te brindan en la universidad o un instituto como docente no basta. Nosotros creemos que en realidad luego de tener el título, si atravesás una situación de violencia o de cualquier tipo de vulnerabilidad que puedan tener nuestros alumnos y no tenés el material, acercate a alguien que sepa, preguntá, es un poco me parece la iniciativa propia. Si bien hay una formación que te la da el instituto, la universidad, luego tenés que estar vos ahí y decir: "bueno yo estoy trabajando en educación, me encuentro con jóvenes y me encuentro con problemas que por ahí antes un docente no le llegaban a los oídos" (de abuso, de maltrato familiar, de una serie de situaciones). Hoy te encontrás con estas realidades, que tienen que ver con el vínculo que vos establezcas con ese alumno y que el alumno se abra y te cuenta un montón de cosas que por ahí hasta te desbordan y decís "bueno ¿qué hago con todo esto?” Tenés que tratar de buscar información, tratar de asesorarte, de preguntar a los inspectores. Hoy todos tenemos acceso al material. Creo que es una cuestión de compromiso sobre todo de aquellos que trabajamos en la docencia.

G: -Y después te dicen hasta cómo abordar cada situación en la que se te presenta un alumno con un arma en la escuela. Todo lo que tenés que hacer te lo dice, está todo escrito. Y así para cada una de las situaciones, si hay presencia de sustancias tóxicas, etcétera. Está todo escrito en educación. Es leer y apropiarte de eso, que te cambie la mirada. Y sobre todo hay que tratar de entender más a los jóvenes, porque si nos quedamos con la sentencia de que fulano es irrespetuoso, consume, es un violento... y si nos quedamos solo con eso... estamos en el horno. Hay que tratar de poder tener una mirada más crítica. Bueno, a ver, qué le estará pasando a este alumno, qué está sucediendo en la vida de este joven que hace que actúe así. Porque si nos quedamos con lo que vemos, con la apariencia, con el joven 
violento, con el que consume, con el que insulta, con el inquieto, ahí es imposible hacer algo.

G: -Enseguida es como que se lo rotula. Por ejemplo, si trajo un arma a la escuela ya es un delincuente. Y en lugar de poder pensar más allá, de ponerse a reflexionar sobre la presencia de armas... Hay que mirar más allá y no rotularlo, y decir, "no es un delincuente", hay que reflexionar sobre el tema, ir más allá y bueno, ¿por qué la familia todavía tiene armas?

E: - ¿El joven queda como encasillado en una figura de delincuente?

G: -Claro. Como que enseguida sucede eso. Y bueno después no sé, si se presenta una situación de violencia entre dos alumnos lo que uno intenta enseguida es desarticular esa situación, hablar con los chicos, se cita a las familias, se hacen actas, después se trabaja la situación en el grupo de referencia de los alumnos. Hay situaciones que deben informarse a los inspectores, entonces debemos hacer informes y elevarlos a la inspectora de la modalidad de psicología, el equipo directivo a la inspectora de nivel, a la vez ellos le informan al inspector distrital. Está pautado lo que debemos hacer ante cada situación.

M: -Pero yo creo que el hecho puntual para poder abordar la violencia dentro de la escuela es la palabra. En el peor de los casos vos podés tener un alumno desbordado y demás, pero cuando haya un minuto de calma le tenés que hablar. Yo creo que es la única herramienta, si uno intenta callar a ese joven que está enojado lo que lográs es más violencia.

G: -O retarlo o directamente, ponerle sanciones.

M: -En algún punto tenés que tratar de que él pueda expresar qué es lo que le pasó, tratar de trabajar esto... de que hay otra manera de poder vincularse, de que ese no es el espacio.

G: -A veces se produce por malos entendidos entre ellos, terminan peleados porque hubo un mal entendido.

M: -Es que eso es fundamental, de otra manera ya te digo, con sanciones, con amonestaciones, con citar los padres no se resuelve nada si antes no intentas hablar con los chicos. 
G: -Además el hecho de las amonestaciones por ejemplo, se llega... no sé porque mucho no sabemos de eso porque no nos interesa, pero hay como límites para las amonestaciones. Viste que llegas a tantas $i \mathrm{y}$ ? No lo podes echar, porque estas vulnerando sus derechos.

\section{E: -Yo me acuerdo que antes en la secundaria te echaban.}

G: -No se puede, estás vulnerando un derecho. No se puede hacer. Entonces, ¿cuál es el sentido de la amonestación? Suspenderlo tampoco se puede porque también estás vulnerando el derecho a la educación.

M: -Solo queda en la amenaza. Los chicos saben eso, lo tienen claro.

G: -No sirve, para nosotras no sirve.

M: -El tema es hablar y hablar.

G: Sí, en algunas escuelas sigue. ${ }^{10}$ De hecho acá supuestamente sigue funcionando. Nuestra idea es correrlo pero bueno. De hecho se han puesto en lo que va del año.

\footnotetext{
${ }^{10}$ Se refiere al antiguo sistema de sanciones en el que se utilizaba el recurso de la suspensión y la expulsión.
} 


\section{Entrevista grupal con alumnos y alumnas}

Lugar y fecha: "Escuela del barrio ferroviario", noviembre de 2014.

Curso y edad promedio: $3^{\circ}$ (14 a 17 años)

Cantidad de alumnas: 5

Duración: 27 minutos

Organización de la entrevista: el contacto con el grupo es en calidad de ex profesor en la asignatura Construcción de la Ciudadanía. Con ayuda de la directora de la institución, se coordina un encuentro para realizar la entrevista en una "hora libre" (momento en que el grupo no tiene actividades pero debe permanecer dentro del colegio). En primer lugar se proyecta un breve video difundido por redes sociales en el que dos chicas de unos quince años se pelean con golpes y empujones en la puerta de una escuela. Luego de ver el material, se invita a las alumnas del curso a hacer una ronda para intercambiar opiniones y responder una serie de preguntas disparadoras. Se aclara que el objetivo de la charla es recolectar información para mis estudios de posgrado, por lo que la misma será registrada y sus identidades serán preservadas.

Desarrollo:

Alumna 1 (durante la proyección): -No se están pegando, se están agarrando de los brazos.

Alumna 2 (durante la proyección): -Yo la agarro a patadas en el orto y la dejo una semana sin sentarse.

Alumna 3 (durante la proyección): ¿¿Eso fue nada más?

Entrevistador: -A partir de lo que vimos quisiera saber qué opinan: ¿creen que la última pelea fue grave? ${ }^{11}$ ¿Fue algo de menor de importancia?

Alumna 1: -Re despacito fue la pelea.

\footnotetext{
${ }^{11}$ El video que se proyecta muestra una pelea entre dos alumnas en la que, luego de una serie de amenazas, empujones y tirones de pelo, una logra dominar a la otra en el suelo tras pegarle reiteradas veces en el rostro. El video fue captado por la videocámara de un teléfono celular de uno de los 20 o 30 espectadores que se hallaban conformando una ronda en el perímetro de la pelea.
} 
Alumna 4: -En realidad no se pelearon, se agarraron los pelos nada más. Una pelea es cuando se dan en la jeta y se abren la cabeza, algo así. Una vez una chica se me hacía la re mala, era re zorra y me miraba re mal. Le gustaba hacer quilombo, entonces le puse la traba, cayó para atrás y se rompió la jeta.

E: -¿Qué quiere decir mirarse mal?

Alumna 2: -Cuando vos pasás y te miran de la cabeza a los pies...

Alumna 1: -...Te miran de arriba abajo.

E: -Retomando el video de la pelea, me gustaría que lo veamos de nuevo y que observen el papel de los que están alrededor. Hay algunos que promueven la pelea y otros que intentan interrumpirla. ¿Ustedes qué opinan? ¿Dónde se pararían ustedes?

Alumna 5 (durante la segunda reproducción): -Tirarme del pelo es lo peor que me pueden hacer, me caliento más todavía.

Alumna 4 (durante la segunda reproducción): -Yo le pego antes de que me agarren del pelo.

Alumna 1(durante la segunda reproducción): -El día que te vayas a pelear no tenés que tener el pelo suelto porque te agarran de acá abajo. ${ }^{12}$

Alumna 4 (responde con una anécdota): -Yo me agarré a piñas afuera de mi casa, ¿viste esa época en que le decían bicho feo a todo el mundo?... Yo le decía bicho feo a mis amigos. Dos pibitas pensaron que les dije eso y parece que se lo tomaron mal, se dieron vuelta y me empezaron a mirar mal, empezaron a bardear. Una me dice: “¿qué decías vos?”...Y yo le estaba hablando a un amigo, entonces la piba me dice "vos cortala", mientras se iba. Le digo "vos cortala qué", entonces voy y la busco y nos agarramos a piñas afuera de mi casa. La otra corrió... se re cagó la que bardeó. Se metió mi hermana y la empezó a rasguñar, entonces yo la saqué para que no la rasguñe y viene la otra de atrás para pegarme a mí. Cuando me pegó me di vuelta y le agarré la remera porque se quería ir. Después me agarró con un palo y también me quiso agarrar una señora de 30 años que me pegó en la cabeza. Todavía tengo un chichón.

Alumna 1: - ¡Y denunciala!

\footnotetext{
${ }^{12}$ Hace referencia al pelo detrás de la nuca.
} 
Alumna 4: -No llegan a ningún lado las denuncias.

Alumna 3: -A mi prima también le pegó la mamá de una compañera. Se ve que la mina ya era quilombera. Mi prima no porque tiene trece años y no tiene nada que ver con lo que son ahora, vive en Claypole. Empezó todo por Facebook porque la otra le decía cosas y mi tía también. Ella es re quilombera porque ya son así en el barrio, viste cómo son. Mi prima nada que ver, es re tranquila. Un día estaba por entrar al colegio y va la madre de la compañera, entonces la hija le dice: "ella era", y la madre le pegó una cachetada y le quería seguir pegando, entonces mi prima llama a la madre e hicieron una denuncia y hablaron con la escuela para que la echen.

Alumna 4: -La denuncia no sirve, si esta señora ya tenía un par por pegar.

E: -¿Qué opinan del día a día en su escuela? ¿Creen que se viven episodios de violencia acá?

Alumna 1: -Lo que pasa acá es algo muy chiquitito, porque yo veo la tele lo que pasa en otros lugares y esto no es nada. Estos no se hacen nada pero allá terminan muertos y las pendejas se tienen que operar porque les hacen mierda la cara con un cuchillo.

Alumna 2: -En este colegio son grupos chicos dentro de todo. En otros colegios hay grupos más grandes y hay más problemas.

E:-Quisiera leerles una frase que me dijo una vez un alumno de secundaria: "cuando camino por la calle la gente que me ve se cruza de vereda. Tanto me escapan que un día voy a hacerles algo de enserio.” ¿Creen que hay una imagen armada del "pibe chorro”? ¿Qué opinan de la frase?

Alumna 2: -Que tenía cara de chorrito.

Alumna 1: -Que tenía cara de captura.

Alumna 3: -Que tenía cara de secuestro.

E: -Yo creo que los jóvenes no son violentos ni delincuentes solo por ser jóvenes, creo que hay una construcción social alrededor de esa imagen del "pibe violento" o "pibe chorro". ¿Ustedes que creen? 
Alumna 2: -Los mismos amigos te llevan a eso.

Alumna 5: -No, eso está en cada uno, si lo haces es porque no tenés personalidad. Si vos no querés hacer algo decís no y listo.

E: -Por último quisiera saber qué soluciones se les ocurren para el problema de la violencia: ¿ustedes qué harían si fuesen directivos y tienen un problema de violencia en su escuela? ¿Cómo lo frenarían? ¿Actuarían con más violencia o intentarían hacer otra $\cos a ?$

Alumna 2: -Tienen que hablar con los padres, tratar de solucionar los problemas familiares y se termina... o llevarlo a un psicólogo.

Alumna 5: -Supongo que nunca se va a solucionar la violencia.

E: -¿Por qué no?

Alumna 2: -Porque no ponen de su parte.

Alumna 3: -Vos fíjate cómo están ahora los padres.

Alumna 5: -Vos antes chocabas con el auto y no pasaba más que un grito, ahora chocan y te pegan un tiro.

Alumna 3: -Antes por robarte un celular no te pegaban, no te violaban, no te mataban y ahora hacen todo eso. Entonces ahora ya fue, cagaron, no lo solucionaron antes, ahora menos lo van a solucionar.

Alumna 4: -Como hay más droga, van a robar locos y no se dan ni cuenta lo que hacen.

E: -¿Quieren agregar algo más?

Alumna 3: -Ahora está muy fácil conseguir droga.

Alumna 4: -En la esquina, de noche, si querés conseguir te venden. Es re fácil. 
Alumna 5: -Ahora hay más droga. Acá entra mucha, se consigue rápido y encima están las barras bravas de [un equipo de fútbol local] que tienen la cabida con los del barrio, así que ellos manejan todo el negocio de las flores. ${ }^{13}$

E: ¿ O sea que la droga agrava el problema de la violencia? ¿Cuándo se drogan no tienen conciencia de lo que hacen y pueden hacer más daño?

Alumna 5: -Igual por un porro no van a salir a robar, ahí está la cocaína. Ahí sí, se toman una línea y los pibes no entienden nada. También le dan a la bolsa. Cuando tienen plata se la re deliran, con lo que trabajan compran droga y para las fiestas consiguen pepas.

Alumna 4: -Había una juntita que andaba robando.

\footnotetext{
${ }^{13}$ Para preservar el anonimato de los informantes, preferimos omitir el verdadero nombre del club de fútbol.
} 


\section{Entrevista grupal con alumnos y alumnas}

Lugar y fecha: "Escuela del centro", agosto de 2015.

Curso y edad promedio: $1^{\circ}(12-13$ años $)$

Cantidad de alumnos y alumnas: 14

Duración: 20 minutos

Organización de la entrevista: el contacto con el grupo es en calidad de profesor en la asignatura Construcción de la Ciudadanía. Hacia la finalización de una jornada de clases en la que se trabajó la violencia como contenido (con la correspondiente aprobación de las autoridades), los invito a conformar una ronda para debatir sobre el tema. Antes de introducir la primera pregunta, aclaro que la conversación será grabada preservando sus identidades con el fin de recolectar información para mis estudios de posgrado. Dada la multiplicidad de voces, solo designaré a los entrevistados como "alumno" o "alumna".

Desarrollo:

Entrevistador: ¿¿Qué significa para ustedes la violencia?

Alumno: -Maltrato.

Alumno: -Burlas.

Alumna: -Bullying.

Alumno: -Discriminación.

Alumna: -Violencia sexual.

Alumna: -Violencia de género.

Alumna: -Violencia verbal.

E: -Un insulto, ¿puede ser considerado como un acto violento? ¿O únicamente podemos hablar de violencia cuando hay golpes? Recuerden que me interesa escuchar sus opiniones, no hay respuestas buenas ni malas, sencillamente digan lo que piensan.

Alumno: -Hay muchas clases de violencia 
Alumna: -Hay violencia verbal, violencia de género

E: -¿Ustedes creen que en la escuela a la que asisten hay violencia?

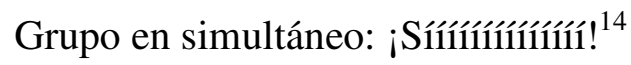

E: - ¿Todos creen lo mismo? ¿Nadie piensa distinto?

Alumno: -Hay muchísima violencia.

Alumna: -Mucho bullying.

E: -¿Recuerdan algún caso?

Alumna: -Nos cagamos a palos.

Alumno: -A principio de año Sandra le tiró una silla a Nahuel porque le tenía envidia porque él se hacía el cheto. ${ }^{15}$

E: -¿Por qué creen que empiezan las peleas?

Alumno: -Por hacerse los chetos, por hacerse los agrandados.

Alumna: -Por envidia.

Alumno: -Porque nos puteamos.

E: -¿Que significa hacerse el cheto? ${ }^{16}$

Alumna: -Cuando alguien se empieza a vestir bien y se hace el otro con vos.

E: -También escuché en reiteradas ocasiones que las peleas empiezan porque se miraron mal. ¿Qué opinan ustedes?

Alumno: -Es mirarse de abajo a arriba. ${ }^{17}$

E: -¿Ustedes creen que la escuela ayuda a resolver los problemas de la violencia?

\footnotetext{
${ }^{14}$ La respuesta a esta pregunta fue verbalizada en simultáneo por la mayoría de los entrevistados con una fuerte convicción respecto de la existencia de la violencia en su institución.

${ }^{15}$ Los nombres originales fueron modificados para preservar la identidad de los informantes.

${ }^{16}$ Frente a esta pregunta los alumnos comienzan a señalar a uno de ellos como representante de la expresión "cheto".

${ }^{17}$ Poco después de decir esto varios alumnos intentan hablar a la vez hasta que una alumna capta la atención con una amenaza en voz alta: "cerrá el orto porque te rompo la cara".
} 


\section{Grupo en simultáneo: -¡Noooooooooooo!}

Alumna: -Al contrario, creemos que lo empeora más todavía. Porque si alguien te mira mal y vos se lo decís al profesor -y el profesor le va a hablar-, entonces después le va a dar más rabia todavía.

Alumna: -Así nos pasó a nosotras.

E: -¿Qué les pasó a ustedes?

Alumna: -Un día nos estábamos peleando y nos encerraron en biblioteca para retarnos. ${ }^{18}$

E: -Retomando lo que decían, ¿ustedes creen que la escuela empeora los problemas de la violencia porque al denunciar a alguien después va a tener más bronca?

Alumna: -Claro porque vos la denunciaste. La persona no es estúpida, se va a avivar.

E: - ¿La escuela tiene que tomar alguna medida?

Alumna: -Sí, pero se va a seguir alimentando la bronca de la persona que vos denunciaste. ${ }^{19}$

E: -¿Quiénes creen que son más violentos, los hombres o las mujeres?

Mayor parte del grupo en simultáneo: -¡Los hombres!

Alumno: -¡las mujeres!

Alumna: -Para mí son los dos igual de violentos.

Alumna: -Vos andás por la calle y nunca falta una pelea entre dos mujeres.

Alumno: -Antes eran solo los hombres.

Alumna: -El otro día fuimos a la parada y había una morocha y una rubia que se estaban cagando a trompadas.

\footnotetext{
${ }^{18}$ En ese momento del diálogo una alumna interrumpe el relato de la que estaba hablando manifestando que lo que decía no era cierto. Acto seguido comienza un intercambio de acusaciones sobre lo acontecido en un tono cada vez más elevado. En ese momento de la entrevista, y durante uno o dos minutos, se torna imposible distinguir palabra alguna.

${ }^{19}$ En ese momento solicito al grupo en general que se respeten mientras hablan debido a que se me dificulta entender el contenido de las conversaciones. En medio del bullicio una alumna levanta la voz y le dice a un compañero: "cerrá el orto pibe", acto seguido el compañero hizo silencio.
} 
Alumno: -El otro día acompañé a mi mamá a La Plata y había una mujer que le cortaba la cara a otra con un cuchillo.

Alumno: -Mirá, acá tengo un video de una amiga que se cagó a trompadas. ${ }^{20}$

E: ¿¿Dónde ocurrió la pelea del video?

Alumno: -Acá en la puerta de Compumundo.

Alumna (riéndose, durante la reproducción del video): -Mirá como le partió la cara.

Alumna (durante la reproducción del video): -Le ganó la morocha porque es más villa, la otra no sabe pelear.

${ }^{20}$ El video muestra dos chicas amenazándose mutuamente hasta que una de ellas arremete con un golpe de puño en el rostro de la otra, desequilibrándola y ocasionándole una caída. El video fue captado por la videocámara de un celular de alguno de los diez o quince espectadores. Cabe destacar que los observadores conformaban una ronda alentando el enfrentamiento con gritos y vítores. 


\section{Entrevista grupal con alumnos y alumnas}

Lugar y fecha: "Escuela de la periferia norte", noviembre de 2015.

Curso y edad promedio: $2^{\circ}(13 \text { a } 16 \text { años })^{21}$

Cantidad de alumnos y alumnas: 12

Duración: 25 minutos

Organización de la entrevista: el contacto con el curso es en calidad de profesor en la asignatura Construcción de la Ciudadanía. En la última jornada de clases, con la correspondiente aprobación de las autoridades, convoco voluntariamente a aquellos que estén dispuestos a responder una serie de preguntas sobre el tema de la violencia. Se informa a los alumnos que la conversación será registrada con el objetivo de recolectar datos para mis estudios de posgrado y que sus identidades serán preservadas. De treinta y siete alumnos, permanecieron doce. Dada la multiplicidad de voces, solo designaré a los entrevistados como "alumno" o "alumna".

Desarrollo:

Entrevistador: ¿¿Qué es la violencia para ustedes?

Alumno: -Bullying.

Alumno: -Peleas.

Alumno: -Insultos.

E: -Entonces podríamos resumir que la violencia para ustedes es el bullying, las peleas y los insultos, ¿podrían agregar algo más a esta información?

Alumno: -Amenazas.

E: -¿Creen que existen situaciones de violencia en esta escuela?

Alumno: -¡Sí! Y también en todas partes. ${ }^{22}$

E: -¿Me pueden contar algún hecho?

${ }^{21} \mathrm{El}$ amplio margen de edad se produce a causa del alto grado de repitencia que evidencia el curso.

${ }^{22}$ Varios alumnos dijeron "sín" al mismo tiempo para responder la pregunta. 
Alumno: -A una cuadra de la puerta se pelearon varios alumnos de la escuela.

Alumno: -Yo antes iba a otra escuela y me tuve que cambiar porque siempre nos peleábamos en la parte de atrás de la escuela.

E: -¿Por qué motivo se peleaban?

Alumno: -Nos peleamos porque sí, porque me miraban mal y me decían cosas y yo me defendía... me hacía respetar. Además repetí tres veces así que me expulsaron.

E: -¿Y recientemente ocurrió algún hecho?

Alumna: -Dos chicas del curso se pelearon.

E: -¿Qué pasó?

Alumna: -Porque ella le fue a decir que quería pelear con ella y ella le dijo que sí para no quedar mal. Aparte se tenían asco las dos.

Alumna (una de las protagonistas de la pelea): -¡No mentira!

E: ¿¿Qué quiere decir que se tenían asco?

Alumna: -Que se bardeaban.

Alumna: -Se miraban mal, se decían zorra y esas cosas.

E: - ¿Pueden identificar el motivo de la pelea? Es decir, ¿por qué empezó?

Alumno: -Yo creo que fue por celos. ${ }^{23}$

Alumna: -Las dos se llevaron re mal siempre.

E: -¿Creen que fue una pelea grave?

Alumna: no.

E: -¿Recuerdan alguna pelea grave en la escuela?

\footnotetext{
${ }^{23}$ En ese momento del diálogo comienza un intercambio de acusaciones sobre lo acontecido en un tono cada vez más elevado. En ese momento de la entrevista, y durante uno o dos minutos, se torna imposible distinguir palabra alguna.
} 
Alumna: -Sí, una chica quiso defender a otra porque no sé qué pasó y se cagaron a palos bien piola.

E: -¿Quiénes se pelean más, varones o mujeres?

Alumnas en simultáneo: -¡Las mujeres!

E: -¿Por qué motivo?

Alumna: -Por un chico.

Alumna: -Para hacerse las zarpadas, para hacerse la "popu”.

E: -¿Qué significa “hacerse la popu”?

Alumna: -Vos no te querés pelear y si te dicen que te pelees, te peleás.

E: -¿Y quién dice que te pelees?

Alumna: -La mala junta.

E: -¿Ustedes creen que la escuela ayuda a resolver los problemas de la violencia?

Alumna: -No, la escuela no hace nada. ${ }^{24}$

Alumna: -Solo llaman a tus papás.

E: -¿Qué hizo la escuela en el caso que me contaron?

Alumna: -Llamaron a los padres de una chica y empezaron a decir cualquier cosa.

E: - ¿Cómo creen que podrían disminuir los niveles de violencia?

Alumna: -Hablando.

Alumna: -Hablando con la persona que es violenta.

Alumna: -Por hacerse la linda, una chica, que es mi prima, me quiso pegar a mí y una vez vino a mi casa y yo la empujé y no dijo nada. ${ }^{25}$

E: -¿Qué es “hacerse la linda”?

\footnotetext{
${ }^{24}$ Varios alumnos respondieron al mismo tiempo que no.

${ }^{25}$ Por segunda vez en la entrevista el debate se sale de control con acusaciones en tono elevado de voz cuyo contenido es imposible de distinguir debido a la superposición de voces.
} 
Alumna: -Es mirar de reojo, pero mirando mal, porque son bolivianas y nosotras somos blancas. Se enojan porque nosotros somos más lindas.

Alumna: -Acá hay muchos bolitas.

Alumna: -Yo no puedo hablar con las bolivianas porque a veces te pegan por ser linda nada más.

E: ¿ ¿Sólo las bolivianas te pegan por ser linda?

Alumna: -No, las mismas pibas. Se sienten feas ellas y te pegan porque son feas y vos sos linda.

E: - ¿Eso pasa muy seguido?

Alumna: -Sí pasa ¿no vio la tele? "Me pegaron por ser linda” siempre dicen las chicas.

E: -¿Qué opinan de las sanciones que emplea la escuela?

Alumna: -Eso no sirve para nada porque volvés con más bronca.

E: ¿¿Pueden agregar más información?

Alumna: -La violencia viene de la casa, si en la casa recibe golpes o ve golpes después va a andar a los cachetazos.

E: -¿Cómo creen que se podría resolver el problema de la violencia?

Alumna: -Hablando.

Alumna: -Yo un día conocí a la hermana de una chica peleadora y le dije que si quería cambiar esta chica se tenía que separar de la familia. Que se vaya a vivir a otro lado.

E: ¿¿Cómo ven el barrio? ¿Tiene problemas de violencia?

Alumna: -No, este barrio es re tranquilo.

E- ¿Tienen algo más para agregar sobre el tema de la violencia?

Alumna: -Si te querés pelear le decís “¿qué me mirás corte piola? Vení a pelear, vení”. O le decís “¿sos piola vos?”, “los piolas se cortan” y pum pum pum. O le decís en la cara “¿qué mirás?" Y pum. 